Faculdade de Filosofia, Letras e Ciências Humanas Universidade de São Paulo

\title{
A DERIVAÇÃO SUFIXAL DO PORTUGUÊS: ELEMENTOS PARA UMA INVESTIGAÇÃO SEMÂNTICO-HISTÓRICA
}

Tese com vistas à obtenção do título de Livre-Docente Departamento de Letras Clássicas e Vernáculas Universidade de São Paulo

Área: Filologia e Língua Portuguesa

Opção no 9: Morfologia Histórica da Língua Portuguesa

Prof. Dr. Mário Eduardo Viaro

São Paulo

2011 
SUMÁRIO

Introdução

1. Pressupostos para o estudo morfológico

2. Apreciação crítica de alguns pressupostos vigentes

3. A questão da existência de um sufixo

4. Acerca de uma metodologia para o trabalho com sufixos

100

5. Gênese do sufixo -eiro: o sufixo-arius ( $a, u m)$ no sistema latino

6. Os sufixos portugueses -eiro e-ário

7. 0 sufixo -eiro num corpus do português medieval

8. Uma cronologia do sufixo -eiro(a)(s) em português

Anexo 


\section{INTRODUÇÃO}

A Morfologia Histórica é e não é um estudo recente. As classes de palavras estão

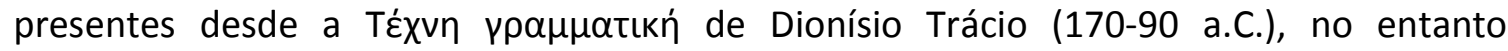
segmentá-las, como se fazia já no século VI a. C. na Índia, foi algo que tomou dimensões consideráveis no Ocidente apenas na segunda metade do século XIX. Podemos dizer que o fazer Morfologia não é algo posterior à criação do nome da ciência no século XIX. O primeiro que, aparentemente, usou o termo Morphologie para as línguas foi August Schleicher em 1859, adotando-o da Botânica, onde fora criado por Goethe em 1796 e disseminado logo a seguir pela Fisiologia e pela Anatomia (Salmon 2000). No século XX, o termo ainda não era de ampla aceitação: Eduardo Carlos Pereira preferia organographia e Said Ali dizia lexeologia. Todo estudo de Morfologia do século XIX para além do enfoque gramatical privilegiava a diacronia. Mais tarde, no século XX, o Estruturalismo priorizaria o estudo sincrônico centralizado no sistema, segundo as interpretações vigente do Cours de linguistique générale. Nos Estados Unidos, o predomínio dos estudos sincrônicos ocorria paralelamente tanto no Estruturalismo quanto no Gerativismo até meados da década de 80 do século $X X$.

Situada entre a Fonologia e a Sintaxe (com as quais muitos queriam e ainda querem fundir, o que causaria a perda da identidade da Morfologia), os estudos morfológicos privilegiam a forma, embora jamais consigam distanciar-se do conteúdo. A integração entre Morfologia e Semântica é bastante evidente no nível lexical. É bastante corriqueiro hoje opor uma Morfologia a uma Lexicologia, conforme os moldes de Aronoff (1976). Segundo esse modelo, de inspiração estruturalista e gerativa, à Morfologia caberia apenas o que é produtivo, ao passo que o componente irregular e improdutivo formaria o Léxico. Este trabalho debaterá o tema da relação entre as duas áreas da Linguística. No momento, é importante observar que entendemos por Morfologia o estudo das classes de palavras, as unidades lexicais que compõem essas classes e os elementos mínimos significativos que compõem essas unidades lexicais. À Lexicologia cabe estudar tanto a neologia quanto o arcaísmo das unidades lexicais, pois investiga, principalmente, a polissemia resultante para além dos elementos que as compõem, assim como a datação de cada acepção. Nosso 
foco, portanto é morfológico, embora o lexicológico e o semântico, intrinsicamente ligados e próximos, surjam a cada momento.

É fácil percebermos que um estudo morfológico pode visar, por meio de um recorte provisório e artificial, focar um sistema linguístico qualquer e delimitá-lo no tempo. Poderia ir mais longe: ancorar-se em testes com os falantes e dialogar com a Psicologia, que tem proporcionado recentemente tantos avanços na área da cognição linguística. Desse modo, estaríamos diante de um estudo de Morfologia Sincrônica. Se, contudo, não é a comunicação ou a sensação psicológica do falante que entra em jogo, mas os componentes formadores das unidades lexicais, bem como o trânsito entre formas simples e derivadas (ou então entre classes distintas de palavras), apenas estaremos suficientemente abastecidos de dados e argumentos, se nos valermos de um viés diacrônico. Uma Morfologia Diacrônica que flagre a dinâmica e a essência de uma língua, porém, é extremamente complexa. Concordamos, com Mattos e Silva (2008), acerca da sutil distinção entre diacrônico e histórico, embora não com a mesma valoração daquela autora. O elemento associal de um estudo diacrônico não é visto por nós como algo menos importante que o elemento social do estudo histórico. A razão dessa gradação fictícia entre o associal e o social advém do nosso precário conhecimento da polêmica neogramática ao final do século XIX e do ainda mais precário conhecimento dos argumentos que embasaram a "derrota" dos neogramáticos, como os usados por Hugo Schuchardt. O resultado dessa polêmica formou as bases da Linguística do século XX. É do nosso parecer que esse elemento diacrônico desvinculado de um sistema existe e é interessante de se estudar, como tentaremos demonstrar. No entanto, se paradoxalmente chamamos nosso estudo de histórico não é porque o achamos mais abrangente ou completo que o diacrônico, mas porque o caráter sutil e até mesmo antiintuitivo da diacronia (que nos aproxima dos insights dedutivos de tantas outras ciências) é mais difícil de ser atingido por si próprio do que pelo empirismo histórico. Aliás, segundo Popper (1967), dentre tidas as ciências, só à história é possível conceder um legítimo empirismo epistemológico. 
O presente trabalho é fruto de pelo menos treze anos de investigação, que inclui não só diálogos com especialistas e com falantes nativos, mas também muita leitura sobre o fenômeno da sufixação derivacional. Sinto-me aqui honrado por prestar meus agradecimentos a tantos interlocutores. Inicialmente, à profa. Dra. leda M. Alves, da FFLCH-USP, que cedeu tantas vezes espaço a mim e aos meus orientandos na pluralidade teórica de seus encontros anuais de TermNeo, à profa. Dra. Rosa Virgínia Mattos e Silva, da UFBA, homenageada no Rosae que me homenageou ao permitir que eu ministrasse um curso de Etimologia na Bahia em 2009, à profa. Dra. Graça Maria Rio-Torto, que me acolheu tão bem na Universidade de Coimbra aquando de meu tão prolífico pósdoutoramento. Um momento especial para agradecer à FAPESP e ao CNPq por tantos recursos investidos em mim e em meus orientandos e a todos aqueles que estiveram e estão juntos no fortalecimento e na divulgação de nossas ideias na forma do nosso Grupo de Morfologia Histórica (GMHP), da Universidade de São Paulo (www.usp.br/gmhp), especialmente às minhas incansáveis doutorandas Nilsa Areán-García e Érica Santos Soares de Freitas. Agradecimentos especiais também à profa. Dra. Valéria Gil Condé, à profa. Dra. Elis de Almeida Cardoso Caretta, ambas da FFLCH-USP e a meus orientandos de doutorado, mestrado e iniciação científica (Alice Pereira Santos, Andréa Lacotiz, Juliana Bianchi Leone, Antônio Fernandes Góes Neto, Juliana Silva Lins, Mônica Yuriko Takahashi). Aos demais participantes do GMHP, Vanderlei Gianastacio (FTBSP), Zwinglio $O$. Guimarães-Filho (IF-USP), prof. Dr. Martin Becker (Universität zu Köln), prof. Dr. Daniel Kölligan (Universität zu Köln), prof. Dr. Michael Ferreira (Georgetown University) e tantos outros que colaboraram direta ou indiretamente para as conclusões apresentadas nessa tese, meu sincero e cordial obrigado. 


\section{PRESSUPOSTOS PARA O ESTUDO MORFOLÓGICO}

Trabalhar com algo tão específico como sufixos parece demandar apenas uma afiliação a uma determinada corrente ou aceitar tacitamente vários pressupostos, que, aos poucos, foram acumulados ao longo da História da Linguística. No entanto, é do nosso parecer que os problemas investigados pelas ciências devam ser entendidos à luz de pressupostos claramente definidos e epistemologicamente fundamentados, sob pena de cair em contradição ou em dogmatismos. Toda ciência supõe um objeto de estudo e a língua é o da Linguística.

Cumpre entender, portanto, o que parece ser óbvio: que é a língua? Ora, os sufixos são componentes dessa língua. Portanto, o melhor entendimento destes só poderá efetuar-se a partir da melhor definição daquela. De fato, a língua é algo demasiado complexo para ser pressuposto. Definindo a língua como um conjunto de palavras e regras, pressupomos outros componentes ainda mais complexos, necessários para entender o que são esses elementos do conjunto (como o falante e a sociedade). Dessa forma, definiríamos a partir de elementos já muito complexos sem questionar uma série de problemas anteriores a ele.

O primeiro problema - o mais simples - é o da existência das línguas. De fato, só podemos dizer que uma língua existe por causa da existência da sua expressão. Somente pela expressão, a existência de uma língua se faz evidente. Dessa forma, a língua não se confunde com a expressão, mas a expressão é condição para dizermos que a língua existe e, portanto, é um objeto real. Essa existência, contudo, não é óbvia. Pois a língua pode existir passivamente (como no caso do último falante de uma língua) ou ativamente. Por meio dela, o falante é capaz de formular enunciados compreensíveis ao outro. Numa situação ideal, a língua existe passiva e ativamente. Um falante deslocado de seu meio original, sem interlocutores que o entendam, costuma aprender a expressar-se na língua de seu entorno: tem por base, ao menos inicialmente, a língua passiva e estratégias de tradução para ser entendido, que envolvem não só a memória, mas o conhecimento de modos de expressão. $O$ que se passa com o que necessita falar em língua estrangeira, 
também ocorre, de algum modo, o tempo todo, na língua materna, na forma da adequação da expressão, a qual se pauta não só na necessidade de exprimir-se, mas também na expectativa de o outro entender o que dizemos. Resumidamente:

OBSERVAÇÃo 1: A existência da língua depende da sua expressão no ato de fala.

OBSERVAÇÃo 2: O ato de fala depende do que se deseja expressar e da projeção que temos da compreensão do ouvinte.

Há, conforme a segunda observação, um componente semântico e um pragmático em qualquer ato de fala. Contudo, o ato de fala pressupõe uma codificação que envolve palavras e regras, num exercício contínuo da parte do falante desde a aquisição da língua com que julga expressar-se. Desse modo, pode-se afirmar que:

OBSERVAÇÃO 3: O falante adquiriu da sociedade a maior parte da língua que fala, portanto, a língua pré-existia ao falante.

O uso dessa língua, da parte dos falantes, tem uma função prática de atingir seus objetivos. Logo o falante percebe que essa ferramenta conduz a certa falibilidade de expressão e, conscientemente ou não, passa a lidar com elementos ideais, tanto na expressão quanto no conteúdo. Esses elementos ideais consistem em relevar muitos dados e fixar-se em apenas alguns que garantam a inteligibilidade da expressão, quer no sentido de reconhecimento da expressão, quer no sentido de compreensão da mensagem. Os elementos relevados, contudo, estão presentes e auxiliam em julgamentos da informação para além do da inteligibilidade.

OBSERVAÇÃo 4: A língua compõe-se de elementos reais herdados e elementos ideais, a partir dos quais, potencialmente, se geram outros elementos reais não-herdados, num ato de fala.

Desse modo, podemos separar, na língua particular de um falante, palavras herdadas e regras, igualmente herdadas, com as quais se produzem atos de falas, obviamente não herdados e palavras também não herdadas. Resumindo: a língua, portanto, compõe-se de elementos reais e ideais e os primeiros se subdividem em herdados e não-herdados. Os não-herdados invariavelmente nascem da análise dos elementos ideais. Os ideais, por sua vez, são formados em parte por meio dos reais herdados e por meio de componentes 
cognitivos da própria espécie humana e, de fato, alguns provavelmente preexistem ao próprio acúmulo de elementos reais na memória.

OBSERVAÇÃo 5: O componente ideal pode atuar em dois níveis: (a) como o elemento real, stricto sensu, é único, opera-se uma generalização no ato da cognição e no ato de fala, de modo que se anula temporariamente a individualidade do ser real único em rumo à criação de um ser real genérico, as palavras; (b) Definidas as palavras com base no que são e do que não são, promove-se uma nova generalização, em que se criam novas palavras sobre seres reais genéricos, expresso pelos genera.

Portanto, a formação de um genus é o mesmo que o de uma palavra, pois ambas são generalizações: nas palavras, seres reais distintos e individuais são entendidos nesse processo como o mesmo ser ideal, ao passo que no genus, seres reais distintos e genéricos mantêm suas distinções, ao mesmo tempo que se cria um novo ser ideal. 0 significado dos genera é facilmente hierarquizável, pois parte de seres reais genéricos para outros mais abstratos, já o significado das palavras permite sobreposições e contradições, pois depende da realidade e da nossa projeção sobre o que ela é. As generalizações e essa mesma contradição intrínseca no significado das palavras faz a língua assumir um caráter infalível, que antes não tinha.

Definidas as palavras, além dos genera, é possível, a partir dos seres reais genéricos, geraram-se outros seres genéricos que não são ideais nem reais. Trata-se de seres fictícios. Sobre esses seres fictícios é possível haver nova generalização e deles se obtêm também genera. A distinção entre o real e o fictício é debatida sobretudo na questão da sua existência, entendida como a verificação sensorial da presença do ser em uma posição espacial e tempo definido. Um ser real ocupa, ocupou ou ocupará uma determinada posição: já um ser que não ocupa, nunca ocupou e jamais ocupará qualquer posição é tido como fictício. Tal oposição pode ser considerada de forma objetiva ou subjetiva, mas prevalece a segunda ao longo a história da Humanidade, embora a primeira pareça ser facilmente intuída não só pelos céticos. Para o presente trabalho, basta dizer que o fictício e o real são indistinguíveis semanticamente, pois, além de formarem genera, expressam- 
se da mesma forma. Cumpre, porém, observar que o fictício não se confunde com o ideal e que o ser fictício, apesar de derivar do real, equivale mais aos seres genéricos do que aos reais.

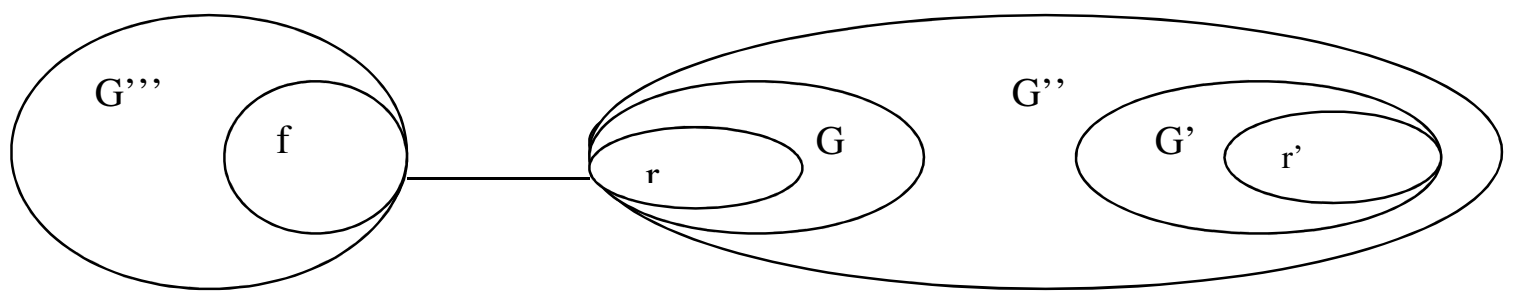

Pelo gráfico acima observa-se que tanto dos seres reais $r$ e $r^{\prime}$ quanto do fictício $f$ é possível fazer generalizações como G, G' e G'”. Das generalizações G e G' nasce uma nova generalização $G^{\prime \prime}$. O nível de $f, G$ e $G^{\prime}$ é o das palavras específicas ou hipônimos (dos quais $r$ e $r^{\prime}$ estão excluídos por não terem expressão e, portanto, não serem palavras). Já o nível de $G^{\prime \prime}$ e $G^{\prime \prime \prime}$ é o das palavras genéricas, ou hiperônimos. Palavras que expressam os seres fictícios $f$ são derivados de seres reais, como $\mathrm{G} \mathrm{e} \mathrm{G}$. Dito de outra forma, o real se opõe ao fictício na questão da existência e os ideais, na generalização. No entanto, o fictício e o ideal se identificam na ausência da existência.

\begin{tabular}{|l|c|c|}
\hline & existência & generalização \\
\hline fictício & $\mathrm{F}$ & $\mathrm{F}$ \\
\hline real & $\mathrm{V}$ & $\mathrm{F}$ \\
\hline ideal & $\mathrm{F}$ & $\mathrm{V}$ \\
\hline$?$ & $\mathrm{~V}$ & $\mathrm{~V}$ \\
\hline
\end{tabular}

Não há portanto, um ser ao mesmo tempo existente $e$ genérico. De fato, um ser genérico também não existe, uma vez que a verificação sensorial se dá sobre os seres reais e não sobre as generalizações. Todo o raciocínio se opera, portanto, sobre palavras que são generalizações e, portanto, seres inexistentes, no sentido que atribuímos à existência. Embora possamos generalizar sobre o fictício, não há relação entre o modo como o fictício é obtido (isto é, pela negação dos traços do real) e como se obtém o ideal (que provém da generalização do real). Do ponto de vista do conteúdo, rigorosamente 
dizendo, as palavras não existem. Apenas na sua expressão é que podemos simbolicamente ter acesso a esses seres inexistentes e genéricos por meio de seres exitentes reais (por exemplo, sons) e genéricos (por exemplo, fonemas), o que nos remete de volta à observação 1 .

Num modelo linguístico, um ser ideal como uma língua homogênea, isto é, que independa da variação dos falantes que a usem (Chomsky 1965:4), pode ser entendido tanto como ser fictício, quanto como derivado do real. Será fictício se se pressupõe que uma língua com essas características seja uma negação de traços de línguas que realmente existam. Provirá do real se, a partir das línguas reais existentes, extrairmos os elementos que realmente importam. Em nenhum dos dois casos se debate a questão da existência dessa língua homogênea. De fato, não parece razoável crer na existência de um ser apenas por meio de indícios, provas e argumentos, mas nunca de elementos reais. Já seres abstratos - derivados não da negação do real, mas da seleção de traços de seres reais - estão presentes nas metodologias: sua existência não é levada em consideração.

OBSERVAÇÃo 6: Um ser abstrato é uma generalização de seres reais, de abrangência maior que os hipônimos, mas menor que os hiperônimos. Entre os seres abstratos, destacam-se os conceitos, ou seja, palavras da metalinguagem, usadas nas teorizações, as quais fazem alguns recortes que desconsideram provisoriamente elementos complexos importantes, para reincluí-los num segundo momento da teorização.

Conceitos são pertinentes à teoria linguística. A compreensão de que são abstrações e não seres reais ou fictícios permite o trabalho com hipóteses não-demonstráveis. Por outro lado, há o problema da separação entre o real e o fictício, tacitamente aceita aqui. Como vimos, um ser fictício está vinculado sempre à questão da existência. Todo ser possível de ser analisado pelos sentidos é tido como real e, portanto, existente. Um ser que nunca pudesse ser analisado pelos sentidos seria tido como fictício e, portanto, inexistente. Seres abstratos só podem ser analisados pelos sentidos por meio de exemplos, que são reais e, portanto, indiretamente são considerados como existentes. 
Portanto, a existência parece referir-se a situações presentes e futuras. Para situações passadas, a existência depende de testemunhos, cuja veracidade é difícil de ser comprovada. Nesse caso, a existência é testemunhada diretamente ou inferida dos testemunhos. Em todos os casos, a existência é um julgamento do real.

OBSERVAÇão 7: O julgamento da existência de um ser depende da análise da sua realidade ou dos testemunhos que dele se fazem. Todo ser, real ou abstrato, se diz existente se puder ser exemplificado. No caso de não mais existir, precisa ser testemunhado. Os seres fictícios, por serem modificações dos seres reais, são, por conseguinte, inexistentes (também todos os seres abstratos deles derivados).

Todos esses seres, bem como a sua vinculação à realidade e à existência estão presentes na língua no significado das palavras. As palavras, porém, apresentam um elemento expressivo, que é o seu significante.

OBSERVAÇÃo 8: Dentre os tipos de significantes, os que mais importam à Linguística são as denominações, as quais se ligam não só a seres reais (indiretamente por meio de generalizações previstas na observação 5a) e a seres fictícios (diretamente), bem como a conceitos e a hiperônimos. As denominações ocorrem tanto na fala, quanto na escrita e, a partir delas, julga-se a própria existência das palavras.

Palavras que não ocorrem nem na fala nem na escrita, contudo, podem ser abstraídas, como ocorrem nas reconstruções. Dessa forma, dada uma etapa temporal qualquer $X$, haverá sempre uma etapa passada $X-1$ (e outras mais antigas $X-2, X-3 \ldots X-n$ ) e uma etapa futura $\mathrm{X}+1$ (donde outras, posteriores, $\mathrm{X}+2, \mathrm{X}+3 \ldots \mathrm{X}+\mathrm{n}$ ). Daí nasce o primeiro pressuposto:

PRESSUPOSTO DA SEQUÊNCIA ININTERRUPTA: Se uma palavra P ocorre na etapa X-2 e na etapa $X$, intui-se que também existiu * $P$ na etapa $X-1$.

Ora, o pressuposto é tido como verdadeiro para fins teóricos embora possa ser falso na realidade. Uma palavra pode desaparecer e ressurgir artificialmente, como mostram 
muitos exemplos ao longo da História. No entanto, é preciso provar que isso tenha ocorrido, razão pela qual o pressuposto da sequência ininterrupta continua válido.

Outro pressuposto é a inferência de um antepassado:

PRESSUPOSTO DO ANTEPASSADO: Se uma palavra $P$ ocorre na etapa $X$, intui-se que também existiu *P na etapa X-1.

De fato, a negação desse pressuposto seria o mesmo que dizer que a palavra surgiu do nada na etapa $X$ e que é, portanto, um neologismo. Isso necessita de provas e a refutação desse pressuposto é importante para a questão da datação em Linguística. Este pressuposto é um dos mais importantes, como se verá a seguir. Da mesma situação deduz-se uma nova situação:

PRESSUPOSTO DA CONTINUIDADE: Se uma palavra $P$ ocorre na etapa $X$, intui-se que também existirá *P na etapa $\mathrm{X}+1$.

Ou seja, imagina-se que a expressão da palavra não será abandonada, de modo que se pode falar sobre seu futuro, como ocorre com questões como a da produtividade. Diremos que, se, numa etapa $X$, houver algum traço $t$ qualquer presente em duas palavras $P_{1}$ e $P_{2}$, ambas formarão um mesmo conjunto. Deduz-se daí que:

Pressuposto da sistematicidade: Se duas palavras $P_{1}$ e $P_{2}$ ocorrem na etapa $X$, intui-se que também existiram $* P_{3},{ }^{*} P_{4} \ldots * P_{n}$.

A condição do mínimo de duas palavras parece ser mais razoável do que a de uma única. Contudo é possível que uma delas ou ambas também sejam deduzidas, o que equivaleria a dizer que com uma só palavra real não se deduz um sistema, mas com uma real e uma intuída, sim (ou com ambas intuídas). Novamente, não é a questão da existência ou da realidade que cabem na discussão, mas a força maior de argumentação em que há em dois testemunhos ou em dois indícios do que em um único testemunho ou indício. Para que o pressuposto esteja errado, bastaria, porém, provar que o traço $t$ que une as palavras $P_{1}$ e $P_{2}$ tenha sido produzido por coincidência. 
Todos os pressupostos acima parecem conduzir à seguinte afirmação que os resume:

Há ordem nas coisas. Elas se transformam, portanto, vêm de um passado e vão para um futuro. Contudo, mantêm sua essência.

Tal afirmação parece condizer com alguns elementos da cognição humana. Negá-la seria assumir paradoxos que a Filosofia sempre esteve disposta a enfrentar, mas que não serão aprofundados neste trabalho. Passemos dos pressupostos às seguintes definições:

DefinIção 1: Se, numa etapa $X$, a palavra intuída *P é confirmada por meio de uma palavra real $\mathrm{P}$, diremos que houve corroboração de sua existência. Nesse caso ${ }^{*} \mathrm{P}$ passa a ser grafada $P$.

DefINIÇÃo 2: Se, numa etapa $X$, a existência de ${ }^{*} P_{1}$ é mantida por meio de uma palavra real $P_{2}$, que, de algum modo, nos informa algo sobre ${ }^{*} P_{1}$, diremos que houve um indício de sua existência.

Se não há provas da existência de ${ }^{*} \mathrm{P}$, nem indícios, diremos que *P é uma hipótese fraca, pois está mais próxima de um ser fictício do que de um ser abstrato. Nesse caso, por ser impossível refutá-lo, *P deve ser abandonado.

O testemunho do dado, por um lado, choca-se com a questão do "dado corrente", aquele cuja existência não é questionada teoricamente por ninguém. Essa situação não deve ser subestimada. Trabalhar apenas com dados correntes é muito mais complexo do que com dados testemunhados. A existência dos dados dependem de observadores: pode existir para um e não para outro. Dessa forma, é possível que o exemplo dado por um observador não seja aceito por outro, simplesmente pelo fato de ser considerado “inexistente". Nesse contexto de subjetividades, há espaço para situações complexas:

- a existência do dado pode depender da projeção do seu suposto observador. De fato, alguém muito engajado em suas ideias pode crer que o que diz é válido e exista, quando é, na verdade, válido apenas para si ou para um grupo que se identifique com suas ideias. Dessa forma, até mesmo algumas línguas existem para uns e não existem para outros; 
- a existência do dado pode depender de limitações interpretativas do seu observador. Falhas na interpretação ouvida ou lida conduzem a dados que adquirem existência que antes não tinham;

- a existência do dado pode depender do meio. Assim, alguns dados existentes num local não existem em outros. Também dependem do tempo, uma vez que dados existentes ontem podem não existir hoje.

Os dados, portanto, necessitariam de uma catalogação em que se apontam as fontes da sua primeira ocorrência (terminus a quo) e de sua última ocorrência, quando não mais existentes (terminus ad quem). Além disso, para além da generalização que formam as palavras (observação 5a), imaginar que estamos diante do mesmo dado é complexo:

- X e Y podem ser o mesmo dado, embora a grafia seja distinta (variantes gráficas);

- $\mathrm{X}$ e Y podem ser o mesmo dado, embora a pronúncia seja distinta (variantes fonéticas);

- $\mathrm{X}$ e $\mathrm{Y}$ podem ser o mesmo dado, embora o significado seja distinto (variantes semânticas);

- $\mathrm{X}$ e Y podem ser o mesmo dado, embora pertençam a momentos distintos da mesma língua (variantes diacrônicas);

- $\mathrm{X}$ e Y podem ser o mesmo dado, embora pertençam a línguas distintas ou a momentos distintos da mesma língua e não difiram em nada, ou apenas na grafia, ou na pronúncia, ou no significado, ou em todos esses componentes (variantes cognatas).

Dessa forma, $X$ e $Y$ podem coexistir no mesmo falante na mesma época (variantes estilísticas) ou em épocas distintas de sua vida (variantes ontogenéticas), em falantes distintos da mesma época (variantes síncronas), em falantes distintos de épocas distintas (variantes assíncronas). A variação depende, portanto, da idade, da região, da época e de outros fatores sociais. Independente de quantos ou quais são, a questão de se $X$ e $Y$ são o mesmo dado ou não, permanece sujeita a pressupostos. No nosso estudo, o pressuposto 
do antepassado, acima apresentado, se mostra muito importante para decidirmos se estamos ou não diante do mesmo dado:

DefINIÇão 3: se na etapa $\mathrm{X}-1$ não temos a mesma palavra $\mathrm{P}_{1}$ existente na etapa $\mathrm{X}$, mas uma outra, $\mathrm{P}_{2}$, parecida do ponto de vista do significante, do significado ou de ambos, deduz-se que $\mathrm{P}_{1}$ provém de $\mathrm{P}_{2}$ e que dela se derivou (por meio de regras fonéticas ou de inferências semânticas) ou, dito de outra forma, que $P_{2}$ se transformou em $\mathrm{P}_{1}$.

As regras fonéticas são bastante conhecidas, já as inferências semânticas serão discutidas mais tarde neste trabalho. Nesse caso, pode-se admitir que $P_{1}$ e $P_{2}$ sejam variantes diacrônicas da mesma palavra $\mathrm{P}$, que seria, na verdade, um conceito (veja observação 6).

Dessa forma, é mais comum a variação de significantes e significados nas palavras do que nos conceitos, embora nesses também não inexista. Portanto, na menor unidade linguística é preciso prever uma grande variação de formas, bem como de conteúdos (Weinreich, Labov \& Herzog, 1968). Uma unidade linguística com uma só forma e um só conteúdo é também possível, mas apenas como conceito.

Dada a definição 3 , podemos concluir que $P_{1}$ não é uma variante de $P_{2}$ se:

- $P_{1}$ tem o mesmo significado de $P_{2}$ e ambos não provêm da mesma palavra $P_{3}$. Neste caso, dizemos que estamos diante de sinônimos não-cognatos;

- $P_{1}$ tem o mesmo significante de $P_{2}$ e ambos não provêm da mesma palavra $P_{3}$. Neste caso, dizemos que estamos diante de homônimos

- $\mathrm{P}_{1}$ é tradução de $\mathrm{P}_{2}$ e ambos não provêm da mesma palavra $\mathrm{P}_{3}$;

A palavra $\mathrm{P}_{3}$ é conhecida como a origem das palavras $\mathrm{P}_{1}$ e $\mathrm{P}_{2}$. Tudo que foi dito aqui é válido não só para palavras, mas também para suas partes significativas, ou seja, para os elementos de formação, entre eles, os sufixos, aqui estudados. O terceiro caso acima pressupõe o conceito de tradução e o de língua. Devemos, portanto, partir da seguinte situação ideal:

DEFINIÇÃo 4: tradução é a equivalência de uma forma $F$ com um conteúdo $C$ de uma língua $L$ para uma forma $F^{\prime}$ com o mesmo conteúdo $C$ de uma língua L'. 
O conceito de língua é primitivo e independe das definições anteriores:

DEFINIÇÃo 5: língua é o conjunto das palavras e regras entre a etapa $X-n$ à etapa $X$ associada a uma sociedade de falantes que a define como distinta de outros conjuntos de palavras e regras.

Por outro lado, dialeto pode também ser definido como:

DEFINIÇÃO 6: dialeto é o conjunto das palavras e regras entre a etapa $\mathrm{X}-\mathrm{n}$ à etapa $\mathrm{X}$ associada a uma sociedade de falantes que a define como variante de uma determinada língua.

Por sua vez, sociedade de falantes deve ser entendida como:

Definição 7: Do ponto de vista linguístico, uma sociedade é um conjunto supostamente homogêneo de potenciais falantes-ouvintes de uma língua.

Diz-se que são "supostamente homogêneos" pois também sociedade, como língua são conceitos. Essa homogeneidade se deve às nossas projeções da realidade e não, como se pode pensar, a uma realidade de fato. Dessa forma, os conceitos de língua, dialeto e sociedade podem ser entendidos como secundários, por serem de impossível demonstração. Apesar disso, são conceitos operacionais úteis quando não só palavras ou regras são estudadas, mas todas as relações estabelecidas entre elas.

Os fenômenos da língua devem ser entendidos entre duas etapas arbitrárias, ou seja diacronicamente. A razão disso se dá porque os fenômenos de língua não nasceram no momento que se confunde com sua fase atual. Não perceber isso seria julgar as línguas apenas como instrumentos de comunicação. Quando, para além da comunicação, também o código pretenda ser investigado, não é possível partir apenas da intuição do falante ou dos "dados correntes", como visto acima. Além disso, os fatos nos mostram que não houve um terminus a quo idêntico para todos. Os fenômenos de língua num etapa $\mathrm{X}$ não nasceram todos ao mesmo tempo, antes cada um foi herdado de etapas anteriores $(X-1, X-2 \ldots X-n)$. Além disso, sua transmissão se dá como o de qualquer outro bem cultural, ou seja, não está preso a uma determinada sociedade, de tal forma que podemos afirmar que o dado linguístico com frequência não pertence a uma única língua. 
Tal afirmação só é possível quando entendemos a unidade linguística com várias formas e vários conteúdos, para aproximarmos do ser real e fugirmos do conceitual. De fato, o signo inequívoco não é uma realidade, mas um conceito. Além disso, quanto ao significante e ao significado podemos partir da seguinte definição:

Definıção 8: O significante é, do ponto de vista do enunciador, uma sequência de sons ou letras com que se atua, de maneira simbólica (portanto, convencionalmente, o que pressupõe uma história), na evocação de um realidade, de conceitos ou de outras generalizações. Do ponto de vista do receptor, o significante é uma sequência sonora com a qual cumpre associar, de maneira simbólica, uma interpretação do que se ouviu ou leu a uma reconstrução do que se pretende evocar.

Definıção 9: O significado é, do ponto de vista do receptor, uma coleção de atribuições de significantes a seres reais, conceitos ou outras generalizações, presentes na memória dos falantes e provenientes da vivência com uma língua (falada ou escrita) e do ponto de vista do enunciador, um desses elementos da coleção simbolizados num significante para a evocação de uma realidade, de um conceito ou de outras generalizações.

Se é possível colocar em ordem cronológica na ontogênese individual, a compreensão do simbolismo se dá na seguinte sequência:

a) expressão de significados por meio de significantes não-simbólicos (portanto, de forma instintiva);

b) decodificação de significados (também de forma inata);

c) compreensão do funcionamento do código (também de forma inata);

d) decodificação do significante simbólico e simultânea reconstrução de significados sociais;

e) expressão do significantes respeitante às convenções do meio em que vive.

As três primeiras etapas atuam até o momento das primeiras palavras pronunciadas pelo falante, já as duas últimas, por não serem inatas, ocupam a vida toda do falante. 
Na expressão de significados, nem sempre as sequências sonoras são contínuas. Também é possível atribuir significado a sequências descontínuas. Também nem sempre sequências sonoras com significado equivalem a palavras, mas podem equivaler a partes da palavra. Dada uma sequência sonora $x^{1} \cdot x^{2} \ldots x^{n}$ referente a uma palavra $P$, assim como $\mathrm{y}^{1} \cdot \mathrm{y}^{2} \ldots \mathrm{y}^{\mathrm{n}}$ para uma palavra $\mathrm{P}^{\prime}$ que têm em comum uma parte do significado (o que permitiria a criação de um conceito):

DEFINIÇÃo 10: Um elemento terminal significativo seria um sequência $z^{m} \cdot z^{m+1} \ldots z^{n}$ (em que $x^{m}=y^{m}=z^{m}, x^{m+1}=y^{m+1}=z^{m+1} \ldots x^{n}=y^{n}=z^{n}$, de modo que $m>1$ ), à qual se atribui o significado comum de $\mathrm{P}$ e $\mathrm{P}^{\prime}$ (e não $a z^{1} \cdot z^{2} \ldots z^{\mathrm{m}-1}$ );

DEFINIÇÃo 11: Um elemento inicial significativo seria um sequência $z^{1} . z^{2} \ldots z^{m}$ (em que $x^{1}=y^{1}=z^{1}, x^{2}=y^{2}=z^{2} \ldots x^{m}=y^{m}=z^{m}$, de modo que $m<n$ ), à qual se atribui o significado comum de $\mathrm{P}$ e $\mathrm{P}^{\prime}$ (e não $a z^{\mathrm{m}+1} \cdot \mathrm{z}^{\mathrm{m}+2} \ldots \mathrm{z}^{\mathrm{n}}$ );

DeFINIÇÃo 12: Um elemento interno significativo seria um sequência $z^{m} \cdot z^{m+1} \ldots z^{p}$ (em que $x^{m}=y^{m}=z^{m}, x^{m+1}=y^{m+1}=z^{m+1} \ldots x^{p}=y^{p}=z^{p}$, de modo que $m>1$ e $p<n$ ), à qual se atribui o significado comum de $P$ e $P^{\prime}$ (e não a $z^{1} \cdot z^{2} \ldots z^{m-1}$ ou a $z^{p+1} \cdot z^{p+2} \ldots . z^{n}$ );

Todos esses elementos significativos podem ser considerados contínuos. Há, contudo, elementos descontínuos que poderiam ser assim definidos:

Definıção 13: Numa sequência $z^{m} \ldots z^{p}$ em que $m \geq p, m \geq 1$ e $p \leq n$, um elemento descontínuo significativo se formará de alguns elementos entre $\mathrm{m}$ e $\mathrm{p}$ (mas não todos), à sequência dos quais se atribui o significado comum de $\mathrm{P}$ e $\mathrm{P}^{\prime}$;

Dentre os elementos terminais temos os sufixos, os radicais finais de uma composição as desinências flexionais. Dentre os elementos iniciais temos os prefixos, os radicais iniciais de uma composição e desinências flexionais. Entre os elementos internos temos radicais e infixos. Entre os elementos descontínuos temos radicais e moldes fônicos presentes nas construções criadas por simbolismo ${ }^{1}$.

Nosso conceito de sufixo conjuga as definições de língua e de palavra (definições 3 e 5 acima):

\footnotetext{
${ }^{1}$ No sentido empregado por Sapir (1921) em sua tipologia linguística.
} 
DefinIçÃo 14: um sufixo seria uma sequência terminal $t$ nas palavras $\mathrm{P}$ e $\mathrm{P}^{\prime}$, responsável por um significado $\mathrm{S}$ presente em ambas. Se não temos a mesma sequência terminal t mas uma outra, $t^{\prime}$, parecida do ponto de vista do significante, do significado ou de ambos, deduz-se que t e $t^{\prime}$ são o mesmo sufixo, somente se ambos provierem de $t^{\prime \prime}$ (por meio de regras fonéticas ou de inferências semânticas) ou, dito de outra forma, que $t^{\prime \prime}$ se transformou em $t$ e em $t^{\prime}$. Nesse caso, $t$ e $t^{\prime}$ podem pertencer ou não à mesma língua.

O sufixo distingue-se conceitualmente das desinências flexionais e dos últimos radicais numa composição. No entanto, é importante aqui mostrar que a definição de sufixo acima se opõe à de base, donde se obtém a nossa primeira hipótese de trabalho e o nosso primeiro procedimento:

DEFINIÇÃo 15: uma base $b$ é a sequência da palavra $P$, excluindo-se o sufixo $t$.

HIPÓTESE 1: Supõe-se que, ao se formar o sufixo $t$, o significado da palavra P seja formado composicionalmente por meio do significado da base $b$ com o significado inicial do sufixo $t$. Essa composição se dá por meio de elementos significativos subentendidos $s$.

Procedimento 1: o significado de $t$ deve ser expresso por meio uma paráfrase que envolva os elementos significativos $b$, s e $t$. Uma paráfrase é boa quando possível de ser apresentada para mais de uma palavra.

Classes morfológicas como nomes, verbos etc. são conceitos que se definem por meio de questões sintáticas e de morfologia flexional, dito de outra forma, por meio de um comportamento distinto que entram em suas definições. Podemos aceitá-los provisoriamente. É necessário afirmar, contudo, que, dentro da progressão de ideias aqui apresentada, nem todo sufixo é obviamente denominal ou deverbal, por exemplo, também não há nenhuma afirmação sobre palavras primitivas e derivadas e sobre a anterioridade temporal daquelas em relação a estas. Mesmo o conceito que engloba todos os sufixos derivacionais como uma única classe carece de investigação que elucide 
os comportamentos idênticos que justifique a existência da classe. A paráfrase equivaleria à instruction de Corbin (1987).

Para além do agrupamentos semânticos que formam as generalizações e dos agrupamentos formados por elementos iniciais, internos ou terminais do significante, outros agrupamentos podem ser feitos dado o comportamento das palavras na sua combinação para a expressão de outros conteúdos. Assim, podemos dizer que há signos que expressam seres, ações e relações, mas:

DEFINIÇÃO 16: signos só pertencem à mesma classe morfológica se também compartilharem características semelhantes na combinação de bases e elementos iniciais, internos ou terminais. Assim, se A é a reunião de uma base $b$ e um elemento $x$ qualquer e se $C$ é a reunião de uma base $b^{\prime}$ e um elemento $x^{\prime}$ qualquer e se $x$ é idêntico ou parecido com $x^{\prime}$ tanto no significante quanto no significado, diremos que A e C participam da mesma classe morfológica.

DEFINIÇÃo 17: palavras só pertencem à mesma classe sintática se ocuparem a mesma posição na combinação $\phi$ para a expressão de um determinado conteúdo. Por definição, seres, coisas e ações formam classes centrais $C$, ao passo que as relações formam classes secundárias S. Portanto, dada uma combinação $\phi$, na qual há $m$ classes $C$ e $n$ classes S, diz-se que as classes C estarão em relação de coordenação ao passo que as classes $\mathrm{S}$ estarão em relação de subordinação, independente do seu conteúdo semântico.

Dessa forma, entende-se, pela definição 17 que a sintaxe só é válida entre palavras e não entre as reuniões de base e elementos iniciais, internos ou terminais. Dessa forma, a definição clássica de sintaxe refere-se apenas a palavras e não a signos. De fato, para além das palavras, os signos podem dispor de coordenações e subordinações, mas um signo subordinante no nível intravocabular não é necessariamente uma classe central e um signo subordinado não é necessariamente uma classe secundária. Dessa forma, as bases e os elementos iniciais, internos e terminais não formam classes de palavras, mas classes morfológicas, onde a relação com seu conteúdo é mais complexa. 
No caso das línguas indo-europeias (inclusive o português) há pouca evidência de que haja relações de subordinação entre verbos e nomes para além dos índices morfológicos. A subordinação se evidencia melhor no desgaste fonético e nesses casos, uma solução centralizada no sujeito desconsidera desgastes como is > 's em inglês. Por outro lado, uma solução centrada no verbo desconsidera desgastes de pronomes sujeitos como no francês je. Para além dos verbos e pronomes, o desgaste raramente ocorre, salvos os casos de gramaticalização. Assim sendo, valendo-nos da simbologia de Tesnière (1959), o verbo (I) e o substantivo (O) ou seus equivalentes estão numa relação de coordenação. As demais classes, incluindo os adjetivos (A) e os advérbios (E) relacionamse por meio de subordinação evidente. Os elementos internos das classes morfológicas (bases, elementos iniciais, internos e terminais) também estariam numa relação de subordinação. A subordinação dessa forma, por ter sua razão mais no elemento significante do que no significado, carrega consigo também o acento tônico principal $(\text { ictus })^{2}$.

Um fenômeno importante é a translação que seria a mudança de uma classe para outra motivada ou pela sintaxe (quer pela posição, quer por meio de palavras com essa função específica) ou por componentes internos. Determinação, indicações da situação na ação (como agente, paciente ou experienciador), subordinação e coordenação podem ser indicados por palavras que acumulam outras funções (espaciais, temporais, condicionais, causais, referenciais) bem como em elementos iniciais, internos ou terminais de palavras, a saber, artigos, preposições, conjunções, afixos e flexões. Por ser uma mudança, uma translação do tipo $X \rightarrow Y$ envolve necessariamente uma distância temporal dificilmente detectável. É difícil, porém, às vezes saber se no momento de uma derivação, por exemplo, a base era um substantivo ou um adjetivo (ou ambos).

\footnotetext{
${ }^{2}$ Entre as classes morfológicas encontram-se não apenas as classes de palavras, mas também subclasses: em português, entre os substantivos há palavras masculinas e femininas e entre os verbos há conjugações e agrupamentos variados para casos excepcionais.
} 


\begin{tabular}{|c|c|c|}
\hline Transformação & Componentes & Sintaxe \\
\hline $\begin{array}{l}\mathrm{O} \rightarrow \mathrm{O}: \\
\text { substantivos denominais }\end{array}$ & $\begin{array}{l}\text { pedra } \rightarrow \text { pedreiro } \\
\text { pedra } \rightarrow \text { pedrinha } \\
\text { pedra } \rightarrow \text { pedras }\end{array}$ & carro $\rightarrow$ o carro \\
\hline $\begin{array}{l}\mathrm{A} \rightarrow \mathrm{O}: \\
\text { substantivos deadjetivais }\end{array}$ & prático $\rightarrow$ praticidade & verdadeiro $\rightarrow$ o verdadeiro \\
\hline $\begin{array}{l}\mathrm{I} \rightarrow \mathrm{O}: \\
\text { substantivos deverbais }\end{array}$ & entupir $\rightarrow$ entupimento & $\begin{array}{l}\text { narrar } \rightarrow \text { o narrar } \\
\text { narra } \rightarrow \text { quem narra }\end{array}$ \\
\hline $\begin{array}{l}\mathrm{E} \rightarrow \mathrm{O}: \\
\text { substantivos deadverbiais }\end{array}$ & trás $\rightarrow$ traseiro & $\begin{array}{l}\text { não } \rightarrow \text { o não } \\
\text { aqui } \rightarrow \text { o aqui }\end{array}$ \\
\hline $\begin{array}{l}\mathrm{O} \rightarrow \mathrm{A}: \\
\text { adjetivos denominais }\end{array}$ & verdade $\rightarrow$ verdadeiro & flor $\rightarrow$ de flor \\
\hline $\begin{array}{l}\mathrm{A} \rightarrow \mathrm{A}: \\
\text { adjetivos deadjetivais }\end{array}$ & $\begin{array}{l}\text { certo } \rightarrow \text { certíssimo } \\
\text { certo } \rightarrow \text { certeiro } \\
\text { certo } \rightarrow \text { certos }\end{array}$ & alto $\rightarrow$ mais alto \\
\hline $\begin{array}{l}\mathrm{I} \rightarrow \mathrm{A}: \\
\text { adjetivos deverbais }\end{array}$ & $\begin{array}{l}\text { ver } \rightarrow \text { visto } \\
\text { desgaste } \rightarrow \text { desgastante }\end{array}$ & desgasta $\rightarrow$ que desgasta \\
\hline $\begin{array}{l}\mathrm{E} \rightarrow \mathrm{A}: \\
\text { adjetivos deadverbiais }\end{array}$ & diante $\rightarrow$ dianteiro & $\begin{array}{l}\text { sempre } \rightarrow \text { de sempre } \\
\text { lá } \rightarrow \text { de lá }\end{array}$ \\
\hline $\begin{array}{l}\mathrm{O} \rightarrow \mathrm{I}: \\
\text { verbos denominais }\end{array}$ & pestana $\rightarrow$ pestanejar & tiro $\rightarrow$ dar um tiro \\
\hline $\begin{array}{l}\mathrm{A} \rightarrow \mathrm{I}: \\
\text { verbos deadjetivais }\end{array}$ & vermelho $\rightarrow$ avermelhar & vermelho $\rightarrow$ ficar vermelho \\
\hline $\begin{array}{l}\mathrm{I} \rightarrow \mathrm{I}: \\
\text { verbos deverbais }\end{array}$ & $\begin{array}{l}\text { vejo } \rightarrow \text { veja } \\
\text { ver } \rightarrow \text { veríamos }\end{array}$ & ver $\rightarrow$ vou ver \\
\hline $\begin{array}{l}\mathrm{E} \rightarrow \mathrm{I}: \\
\text { verbos deadverbiais }\end{array}$ & atrás $\rightarrow$ atrasar & adiante $\rightarrow$ levar adiante \\
\hline $\begin{array}{l}\mathrm{A} \rightarrow \mathrm{E}: \\
\text { advérbios deadjetivais }\end{array}$ & verdadeiro $\rightarrow$ verdadeiramente & cruel $\rightarrow$ de modo cruel \\
\hline $\begin{array}{l}\mathrm{I} \rightarrow \mathrm{E}: \\
\text { advérbios deverbais }\end{array}$ & ver $\rightarrow$ vendo & ver $\rightarrow$ para ver \\
\hline $\begin{array}{l}\mathrm{O} \rightarrow \mathrm{E}: \\
\text { advérbios denominais }\end{array}$ & lat. senatus $\rightarrow$ senatu & $\begin{array}{l}\text { casa } \rightarrow \text { para casa } \\
\text { dia } \rightarrow \text { um dia } \\
\text { sábado } \rightarrow \text { sábado que vem }\end{array}$ \\
\hline $\begin{array}{l}\mathrm{E} \rightarrow \mathrm{E}: \\
\text { advérbios deadverbiais }\end{array}$ & $\begin{array}{l}\text { logo } \rightarrow \text { loguinho } \\
\text { nunca } \rightarrow \text { nunquinha }\end{array}$ & cá $\rightarrow$ para cá \\
\hline
\end{tabular}

O quadro acima demonstra que um grande número de conceitos tradicionais se mesclam e outros podem ser questionados. De fato, mesclam-se noções como a de flexão, 
derivação e construções sintáticas, não por um esforço de sintetismo metalinguístico, mas porque os elementos que os distinguem não podem ser equacionados pelos pressupostos até agora apresentados. Além disso, não é incomum que o conceito de língua moderna (entendida quer como formações criadas há certo tempo quer como neologismos) se mescle, numa esquematização desse tipo, com outras etapas e outros sistemas. 0 conceito de produtividade parece fazer mais sentido quando tem aplicação de $100 \%$ do que quando há regras com grau de probabilidade ou excepcionalidade:

ESTRATÉGIA 1: uma regra permite que um falante possa apostar numa solução.

Como dito acima, a partir do quadro, outros conceitos podem ser questionados, dando margem a hipóteses operacionais:

HIPÓTESE 2: As classes a que se associa uma palavra podem ser fixas, mas não são necessariamente excludentes

HIPÓTESE 3: Os elementos que encabeçam uma derivação morfológica nem sempre são palavras mas bases.

HIPÓTESE 4: Bases e afixos não têm classes morfológicas, pois dependem do nível lexical.

De fato, na tentativa de corroborar a hipótese 2 observamos que há palavras que pertencem ou à classe $A$, ou à $E$, ou à $O$, independente da sua posição na oração, já há outras que podem ser entendidas ou como A ou como O (classe A/O), como japonês, outras ou como A ou como E (classe A/E), como subindo ou forte, outras ainda que podem ser entendidas como $\mathrm{O}$ ou como $\mathrm{E}$ (classe $\mathrm{O} / \mathrm{E}$ ), como sábado. Classes mistas são muito comuns nas línguas isolantes. Em si, línguas como o chinês não têm classe fixa (e diacronicamente é difícil de decidir também, às vezes), mas a posição é decisiva, de tal modo que a translação pode ser evidente em alguns casos, já noutro a translação é necessária para a decisão. Com relação à hipótese 3 observa-se que uma translação como 
menino $\rightarrow$ meninos só pode ser convencional (ou, quando muito, baseada em frequências de uso ou na aquisição da linguagem), mas morfologicamente não há sentido, uma vez que só se pode pensar numa base menin- $\rightarrow$ menino ou menin- $\rightarrow$ meninos. Também não faz sentido, a não ser do ponto de vista da tradição lexicográfica, dizer que cantar $\rightarrow$ cantei, quando morfologicamente só faz sentido dizermos que cant- $\rightarrow$ cantei. Do ponto de vista do resultado, é por vezes arbitrário decidir a origem da derivação: de alfinetada é possível imaginar tanto que alfinetada $\leftarrow$ alfinetar quanto que alfinetada $\leftarrow$ alfinete. Também nos casos de derivação regressiva, é difícil decidir sem uma regra prática se âncora $\rightarrow$ ancorar ou se ancorar $\rightarrow$ âncora ou ainda se dança $\rightarrow$ dançar ou se dançar $\rightarrow$ dança. Regras que envolvam elementos semânticos (por exemplo: "um objeto concreto é possível nascer uma ação, mas de um fato dinâmico, não") obtêm-se indutivamente e sua aplicação dedutiva, portanto, não é correta. No caso da derivação regressiva, o estudo diacrônico inviabiliza o caráter de lei atribuído a algumas regras dedutivas (cf. lat. collationem > colação $\rightarrow$ colar).

Ainda segundo a hipótese 4 , não faz sentido pensar no resultado como fonte de decisão para saber qual a classe da base, de modo que menin- não pertence à classe 0 nem cant- à classe I (cf. substantivo deverbal canto $\leftarrow$ cant-). Da mesma forma, é difícil imaginar classes a não ser por abstrações ou soluções ad hoc para situações em que a base é um alomorfe ou é opaca, como em femin- $\rightarrow$ feminismo ou chic- $\rightarrow$ chiqueiro.

Por fim, as classes genéricas do tipo A, E, O e I podem não ser as únicas: como vimos há classes independentes criadas por fusão de traços definitórios como $A / E, A / O$ e $E / O$, assim como há outras reunidas no grupo de elementos que promovem a translação $(\tau)^{3}$. Em algumas línguas, translativos são elementos de partida para algumas translações, como em $\tau \rightarrow$ A no inglês if $\rightarrow$ iffy. Até mesmo interjeições entram nessas formações com grande frequência, na formação de palavras onomatopaicas. Nesse sentido, não se trata de um número fechado, mas um número a investigar-se por meio dos resultados das translações. De qualquer forma, o nome deXal deve fazer parte de classes morfológicas e não classes semânticas, donde evitarmos, por exemplo, usos como detoponymic (Dal \&

\footnotetext{
${ }^{3}$ translação e translativo, termos empregados no sentido atribuído por Tesnière (1952)
} 
Namer 2008: 60; Eggert 2008:76). Classes semânticas independem de classes morfológicas e ambas independem de classes sintáticas. Uma correlação entre esses três dimensões possíveis, contudo, quando perfeitamente diferenciadas (e não pautadas por maior ou menor probabilidade) produz um modelo de alta consistência. Na falta de um modelo desse tipo, o termo nome, por exemplo, se torna polissêmico, ora valendo como sinônimo de substantivo, ora como categoria cujas funções substantivais, adjetivais ou adverbiais:

- Em verdad-eiro, a base verdad- equivale semanticamente à palavra verdade e carrega em si o núcleo semântico principal da palavra derivada. O valor nuclear de verdade é obtido por meio da avaliação da paráfrase "que é verdade": sendo verdade, na paráfrase, o predicativo do sujeito de uma oração adjetiva;

- Em jaqu-eira, a base jaqu- equivale semanticamente à palavra jaca, no entanto, o núcleo semântico da palavra se encontra em -eira "árvore que produz". Nesse caso, o valor periférico de jaca se dá pelo fato de ser objeto direto da paráfrase: "árvore que produz jacas";

- Em chiqu-eiro, a base chic- é pouco transparente, mas o núcleo semântico se encontra também em -eiro "local onde se criam". O objeto direto direto "porcos" não está no sufixo, nem na base, mas na palavra.

O nível lexical, portanto, lida com os vocábulos verdadeiro, jaqueira, chiqueiro e não com a composição de um radical verdad-, jaqu- ou chiqu- a um sufixo -eiro. O terceiro caso é mais complexo do que parece. A paráfrase pode ser fantasiosa se nos pautarmos apenas na nossa intuição, uma vez que ela está mais próxima de uma definição do vocábulo do que da composição de um radical (cujo significado nos foge) e um sufixo. Para o mesmo sufixo, isso é observável em:

- chuv-eiro, cuja paráfrase poderia ser, por exemplo, "objeto que se assemelha com chuva" ou "objeto que produz uma chuva artificial" etc., todos com núcleo semântico em -eiro principal e ou ainda "pequena chuva" ou "chuva artificial", que deslocaria o núcleo para a base.

A arbitrariedade de todas essas soluções, por não ser refutável, deve ser abandonada. O sufixo - eiro deveria ter uma produtividade atual ou pretérita, no entanto, 
todas essas soluções parecem simplesmente ad hoc, ou seja, sem outros exemplos que o comprovem. Novamente, do ponto de vista lexical, chuv-eiro é, sobretudo, um objeto (e nesses casos, -eiro invariavelmente conduziria o núcleo semântico), mas no momento da composição do radical com o sufixo (em uma sincronia pretérita, comprovado atualmente apenas regionalmente na língua usual), chuv- carregava o núcleo, uma vez que chuv-eiro era uma "chuva intensa", equivalente a nevo-eiro e outros. Dessa forma, abandona-se a solução ad hoc e atribui-se a paráfrase que descreve a semântica do sufixo com base nos dados. Preferentemente, confirma-se esse significado por meio de outras formas coetâneas, cuja paráfrase também é empregável.

Seja qual for a avaliação semântica da base nas formações sufixais (obscura, pouco clara, clara ou óbvia), uma base será o elemento que se obtém, ao depreender-se o sufixo. Por vezes, essa base tem outros elementos que formam, por vezes, outras classes, a saber, outros sufixos, interfixos, prefixos etc. Cada um desses elementos deve ser estudado diacronicamente à luz da Morfologia.

O que mais nos interessa nesta pesquisa, contudo, é a mudança do significado do sufixo. Como -eiro pôde significar "árvore que produz X" ou "profissão"? Isso já deu ensejo a entender o sufixo como um amontoado caótico de significados, como algo ilógico e, por conseguinte, sem significado. Um amontoado caótico de significados, pode, sob um outro ângulo, ser visto como um conjunto de diversas tradições de significados, constelações lexicais geradas por algum protótipo irreconstrutível. Esses significados são, por sua vez, derivados de outros mais primitivos, assim como ocorre na polissemia, na qual algumas acepções da palavra remontam a um núcleo primitivo comum. Dessa maneira, é possível imaginar uma árvore genealógica de significados (veja capítulos 6 e 7).

De forma alguma, esse conjunto não é ilógico. Antes seria melhor dizer que não lhe cabe o termo "lógica": é, na verdade, alógico, ou seja, a lógica, no sentido estrito da palavra, Ihe é indiferente. Não é possível, portanto, criar um elemento único ou um par por meio de uma intersecção de sentidos ou um arquissemema comum. Não é possível ou é completamente inútil, como preconiza Wierzbicka (1996), postular-lhe um grande significado que abarque todos os demais. Assim, é comum dizer que entre o -eiro de 
laranjeira e o -eiro de galinheiro haja o mesmo significado (“locativo"). Se, por um lado, há uma consistência lógica e operacional nesse procedimento, por outro, há um grande absurdo histórico e a língua é uma instituição e não um jogo. O -eiro de laranjeira não significa "lugar onde há laranja", mas "árvore que produz laranja" e o -eiro de galinheiro não é apenas "lugar onde há galinhas", mas o lugar onde se guardam as galinhas. Não haveria grandes conceitos abstratos donde nascem todos os casos reais: o modelo que se impõe nesta pesquisa deve ser indutivo, e não dedutivo. Deve ser empírico e não trabalhar no nível ideal. Em suma, é nosso objetivo descrever por meio dos indícios semânticos e históricos e não interpretar a partir de abstrações primitivas.

Chamaremos cada significado facilmente caracterizável de um sufixo como um núcleo semântico, que deve ser parafraseável. Uma genealogia desses núcleos semânticos explica a relação que têm entre si, eliminando, pela diacronia, o aparente caos sincrônico. Há palavras que não integram totalmente esses núcleos, nem estão totalmente desgarrados deles, mas se comportam como que orbitando à sua volta.

No caso do sufixo -eiro, aparentemente, a maioria dos casos é de denominais, sendo que os poucos deverbais existentes requerem uma estrutura participial (lavar $\rightarrow$ lavado $\rightarrow$ lavadeira). No entanto, é necessário reconhecer que se hoje vemos o particípio como uma flexão verbal, durante séculos foi visto como uma classe independente. No limite, as diferenças entre nomes, verbos e particípios são convencionais e tradicionais e, por isso, as categorias morfológicas têm certa dificuldade de integrar-se, no signo, totalmente do lado do significante ou do significado.

O maior problema aqui é confundir base com antecedente. Como vimos no pressuposto (6), o antecedente só se atinge por meio de uma reconstrução, para a qual a base é o maior indício. Se vemos um sufixo -eiro na palavra pedreiro, concluímos que seu antecedente foi pedra por meio de uma reconstrução a partir da base pedr-. A base não é livre, o antecedente o é. Por isso é difícil saber se alfinetada vem de alfinete ou de alfinetar, uma vez que só dispomos da base alfinet-. Isso pode gerar três hipóteses de trabalho: 
- há regras definidas pela maioria dos casos atuais e usuais. Assim, se pedra é um objeto e pedrada um golpe, inversamente, a partir de alfinetada, um golpe, só se pode chegar a alfinete, um objeto. Essa regra é dedutiva e incompatível com o método empregado até agora.

- há uma constelação lexical que gerou toda a série alfinete, alfinetar, alfinetada, sem que haja especificamente uma regra que derive uma coisa de outra. De fato, por indução, não há regras em que se gerem algumas classes a partir de outras, como já se mostrou com o caso de colação.

- há uma sequência histórica na série, porém, inacessível, o que obstrui toda tentativa de reconstrução.

De fato, o dado histórico existiu e as três palavras não surgiram ao mesmo tempo, o que contradiria o pressuposto (2). Dito doutra forma, admitir a dificuldade natural de encontrar a palavra antecedente não é o mesmo que preconizar a sua inexistência: a segunda e a terceira hipóteses não dizem a mesma coisa. É possível, no entanto, fazer uma síntese das duas: a sequência histórica é inacessível e não há regra dedutiva que auxilie, no entanto, outros dados de língua podem nortear a reconstrução. Assim, é muito comum observar nas línguas que, a partir do significado "grande quantidade de X", nasça outro mais abstrato, de "intensidade" ${ }^{4}$. Isso pode ser tomado como hipótese de reconstrução, mas, quem de fato contradiz qualquer regra indutiva são os dados, sem que seja necessário criar regras ad hoc, como no caso dos atuais modelos dedutivos.

\footnotetext{
${ }^{4}$ Por exemplo, a palavra portuguesa muito pode indicar tanto intensidade quanto quantidade e, independentemente, o mesmo ocorre com o japonês たくさん (takusan) e com o russo много (mnogo).
} 


\section{APRECIAÇÃO CRÍTICA DE ALGUNS PRESSUPOSTOS VIGENTES}

A despeito da recente denominação, a Morfologia lato sensu talvez tenha sido a área mais explorada dos estudos da linguagem: a sistemática dos paradigmas e as tabelas remontam ao período medieval e, indo mais para o passado, confunde-se com a própria história da Linguística, tomada num sentido lato (Black 2000). Há setores da Linguística que necessitariam de maiores reflexões devido à manutenção de certas perspectivas da gramática tradicional e, com certeza, há ainda necessidade de discutir o lugar da Morfologia. De fato, alguns autores, de acordo com suas perspectivas teóricas, chegaram a propor fusões com a Fonologia ou com a Sintaxe, buscando maior abrangência a seus modelos (Spencer 1991).

Sobretudo quando o mesmo objeto de estudo é focado numa perspectiva sincrônica ou diacrônica torna-se, hoje em dia, evidente a necessidade de questionar alguns conceitos, com o intuito de os definir melhor, se desejarmos que conceitos de uma sejam empregados pela outra ou a auxiliem (Bybee 1985). Cumpre observar que ambas as perspectivas se tornaram mutuamente excludentes entre a década de 50 e a de 90 do século $X X$, quando importantes conquistas da Linguística ocorreram e isso se refletiu na metalinguagem empregada. Recuperar o significado original dos conceitos, alterado pelos modelos é um passo recomendável. Os paralelismos apresentados neste capítulo com uma área tão distinta como é a Zoologia têm o propósito de mostrar que, sobre alicerces claramente definidos, é possível trabalhar com objetos muito complexos - ainda que, obviamente, muito distintos - de modo organizado e progressivo. Localizar incompatibilidades antes de avançar nas fusões das linhas é outra cautela necessária, se tivermos o intuito de aperfeiçoar os mesmos conceitos.

Nesse sentido, discutiremos agora as definições e os pressupostos de termos como produtividade, homonímia e competência, amplamente utilizados pela teoria morfológica sob a ótica sincrônica. Como se verá, tais conceitos, quando da recente reinclusão do elemento diacrônico em Morfologia Derivacional, sobretudo no tocante a processos de afixação, requerem alguns questionamentos. Deter-nos-emos, para tal, no caso dos 
sufixos nas palavras derivadas. Nelas distinguem-se claramente o significado do sufixo como distinto do significado do radical e ambos distintos dos significados da palavra derivada. Spencer (1991:44) flagra esse fenômeno com outras palavras:

the meaning of a phrase tends to be determined compositionally from the meaning of its component words. However, the meaning of words is not always determined compositionally. In some cases, it is the word as a whole which bears the meaning, and the relationship between the meaning of the parts and the meaning of the whole word can be obscure.

Ou seja, parte-se do fenômeno de que cada parte não se apresenta sempre na soma, a qual estaria em outro nível: as partes estudam-se pela Morfologia, o todo pela Lexicologia. A Semântica atuaria nos dois níveis. Da mesma forma, oxigênio e hidrogênio têm propriedades distintas da água, que é a combinação dos dois, mas as três substâncias se estudam pela Química.

O conceito atual de produtividade, utilizado pela Morfologia, reveste-se de grande importância, embora alguns pressupostos que o sustentem nem sempre sejam declarados de maneira inequívoca. Tal assunto não poderia ser discutido sem mencionar o questionamento de Basilio (2002:365):

(...) a pesquisa de produtividade lexical se esteia fortemente em julgamentos de aceitabilidade e interpretação de formas não-existentes; ora, não podemos testar um corpus e as ocorrências nele verificadas podem ser oriundas diretamente de uma lista de entradas lexicais, não se constituindo, portanto, em evidências de operação de processos específicos. As evidências com que podemos lidar são, portanto, de ordem indireta e de difícil obtenção. Por um lado, a eventual ocorrência de afixos deslocados de suas combinações costumeiras; por outro, ocorrências de construções não-dicionarizadas, tomada a não-dicionarização, na falta de critério mais adequado, como evidência do caráter neológico da formação.

Sendo a produtividade entendida como quer Aronoff (1976:35), ou seja, como a possibilidade de uma regra de formação de palavras (RFP) produzir novos itens lexicais, conclui-se que uma regra improdutiva tem sua aplicação limitada a uma lista de bases em que ocorre. Na prática, contudo, segundo Basilio, há uma ambiguidade no uso do termo, uma vez que por produtividade também se entende a "frequência de aplicação, conforme refletida no número de produtos, abarcando, ao mesmo tempo, os níveis de competência e 
desempenho" (Basilio 2002: 366). Urge, assim, atentar para uma distinção entre a produtividade e as condições de produção (que podem ser de ordem variada num dado corpus), feita pela autora, ao separar os elementos produtivos / improdutivos dos elementos mais ou menos operantes. Uma forma possível ao mesmo tempo inclui formas não-existentes no léxico, mas não inclui necessariamente toda forma existente, pois

a classe de construções possível determinada por uma RFP, da mesma maneira que inclui formas não-existentes no léxico, também pode excluir formas existentes, dado que o léxico é um depósito de produtos, heranças e empréstimos e, portanto, não reflete a situação sincrônica da produtividade dos processos lexicais" (Basilio 2002:372).

Além disso, o termo técnico produtivo é polissêmico. Nem todas as palavras criadas e usadas num século serão herdadas pelo século seguinte: algumas simplesmente são abandonadas. Reconstruir o número de palavras abandonadas e sobreviventes é possível, em parte, a partir de uma lista obtida em dicionários nos quais podemos encontrar informação etimológica com relação à sua primeira abonação. Os fatores que participam da integração da palavra ao léxico da língua são parcialmente compreendidos, de modo que a aceitação ou abandono de formas neológicas, nas diversas sincronias que se podem depreender num percurso diacrônico, parece obra do acaso. Como diacronicamente é preciso trabalhar com duas etapas no mínimo, só é possível, na prática, fazer uma avaliação de produtividade com a sincronia atual e uma sincronia pretérita ou com duas sincronias pretéritas. Uma diacronia que pretenda estabelecer o seu terminus a quo no presente fará previsões para o futuro.

Alerte-se para o fato de que um recorte sincrônico de qualquer época de qualquer língua teremos o fenômeno da convivência sincrônica de dados formados em sincronias pretéritas. Servindo-nos dos afixos do português em nossa exemplicação, sabemos que no português do século XXI estão disponíveis aos falantes alguns itens como guerreiro (já testemunhado no século XIII), lisonjeiro (séc. XV) e hospedeiro (séc. XVIII), todos convivendo na sincronia atual. Dado que, de cada sincronia, destacada num estudo diacrônico, se depreende um sistema com características parcialmente distintas (agrupadas arbitrariamente sob o rótulo de língua portuguesa), os itens, pertencentes a 
esses sistemas, refletem antigas produtividades. Parte do resultado delas convive no sistema atual, fazendo-nos voltar à situação heterogênea do léxico. O mesmo se pode pensar da dimensão diatópica e diastrática.

O número que reflete quantidade de itens criados em cada sincronia, somado aos sobreviventes da sincronia anterior (ou seja, todos os itens, menos os que se tornaram arcaísmos) não é, de fato, o mesmo que a capacidade gerativa de cada sincronia, embora ambas recebam, por vezes, o nome de produtividade. Essa quantidade deveria, portanto, ter um nome distinto, para evitar-se ambiguidade terminológica. Propusemos, para tal dado, o termo prolificidade (Viaro 2006), a qual seria equivalente ao cardinal do léxico, segundo nomenclatura da Teoria dos Conjuntos. O mesmo vale para subconjuntos do léxico, como por exemplo, para as palavras derivadas por sufixação. Se, diacronicamente, o número de arcaísmos for constante, ao representarmos a prolificidade num gráfico de palavras sincronicamente válidas, teremos sempre uma curva crescente. Isso, porém, é ilusório, pois não reflete a realidade do que ocorre na língua: as palavras não-abonadas são perdidas para sempre e não podem entrar no cômputo para avaliarmos se existem quedas reais de prolificidade. Desse modo, a prolificidade e a frequência de uso são peçaschave da neologia, uma vez que a capacidade gerativa da produtividade, do ponto de vista do falante, depende intuitivamente delas, sem as quais não seria gerativa. Trata-se dos verdadeiros mecanismos paradigmogênicos que promovem a produtividade. Sob a ótica humboldtiana, a produtividade seria a enérgeia, enquanto o léxico seria o érgon, mas em diacronia, mecanismos de fundo psicológico como a analogia mostram que, inversamente, esses elementos paradigmogênicos (prolificidade e frequência de uso) alavancam a enérgeia.

Se pensarmos que produtividade é a capacidade de ainda se gerarem novos elementos e prolificidade, a quantidade de elementos já gerados, observaremos que a primeira aponta para o futuro do léxico, enquanto a segunda, para o passado.

Nada impede, portanto, que esses termos sejam discutidos conjuntamente. Assim, pode-se afirmar que sufixos como -engo, -isco ou -eba são improdutivos (ou pouco produtivos) e ao mesmo tempo são pouco prolíficos. O mesmo se pode dizer do sufixo - 
eiro no seu sentido 'gentílico', que sofre a concorrência dos produtivos -ense e-ano. Um prefixo cis- é produtivo e prolífico apenas no jargão da Química, assim como o sufixo ídeo o é no da Zoologia. Isso poderia fazer confundir os dois fenômenos, mas nem sempre elementos prolíficos são produtivos ou vice-versa. Contudo, uma altíssima produtividade numa determinada sincronia não garante sempre uma alta prolificidade (como ocorreu na passagem do sufixo latino -iculus para o português -elho). O -eiro para profissões atualmente tem alta prolificidade, mas não goza da mesma produtividade de séculos anteriores, pois foi suplantado por -ista, que é o formador de profissões por excelência na língua atual. Quando estudamos palavras portuguesas criadas no século XV, verificamos que o sufixo -ista era ainda pouquíssimo produtivo. Sua produtividade só aumentará, de fato, no século XIX. Já um sufixo como -eiro, que tinha uma produtividade crescente ao longo do tempo, vem diminuindo sua produtividade geral desde o século XVIII. Os gráficos seguintes foram obtidos por meio dos dados constantes em Houaiss \& Villar (2001):

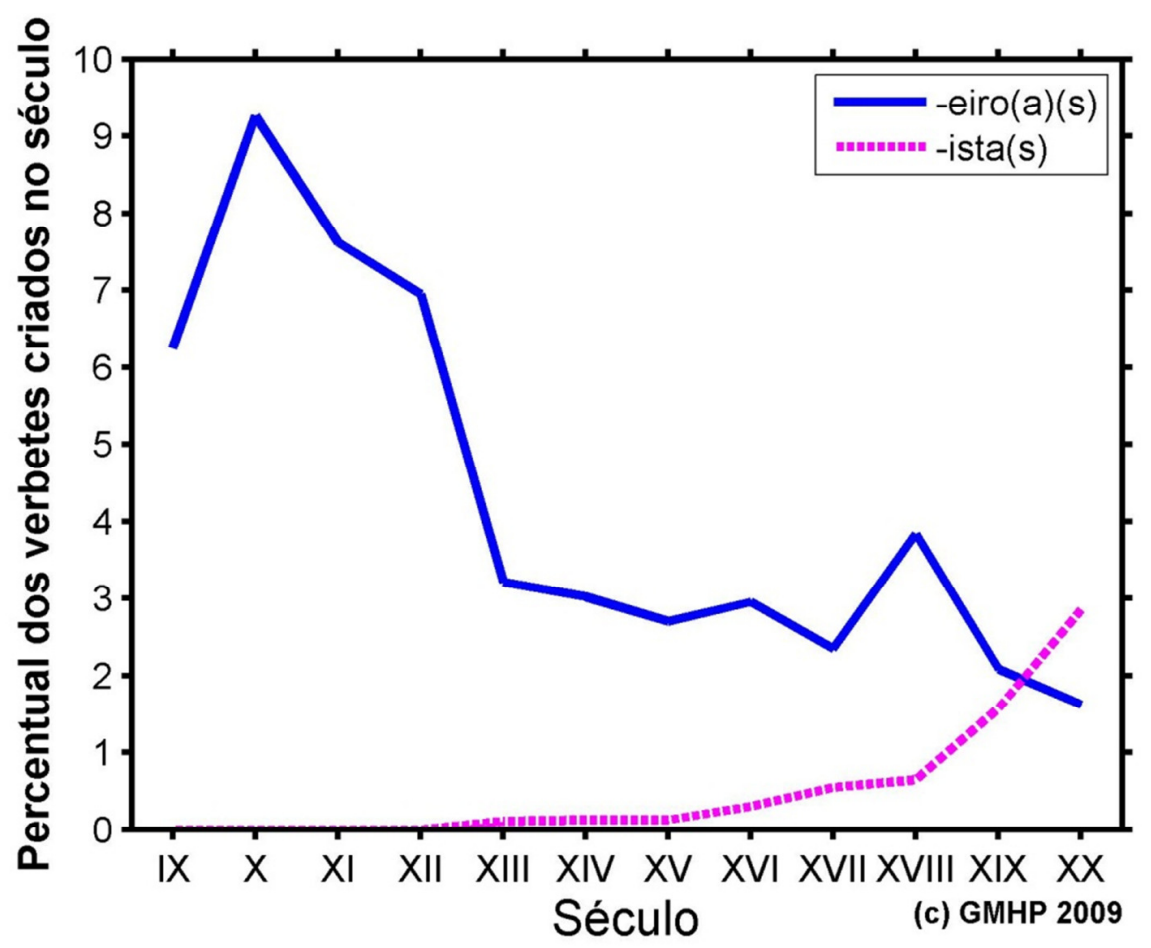

Gráfico 1: Produtividade relativa dos sufixos -eiro(a)(s) x-ista(s) 
O gráfico 1 mostra a produtividade relativa do sufixo, dito de outra forma, sua representatividade ao longo dos séculos. Apresenta o percentual de palavras criadas com determinado sufixo em cada século, sobre o total de criações daquele século. No entanto, dado um sufixo qualquer e o total de criações (pancronicamente falando), pode-se obter a produtividade absoluta de cada sufixo em cada século, como no gráfico 2 abaixo. Nesse caso, também se revela a queda de -eiro face à progressão de -ista.

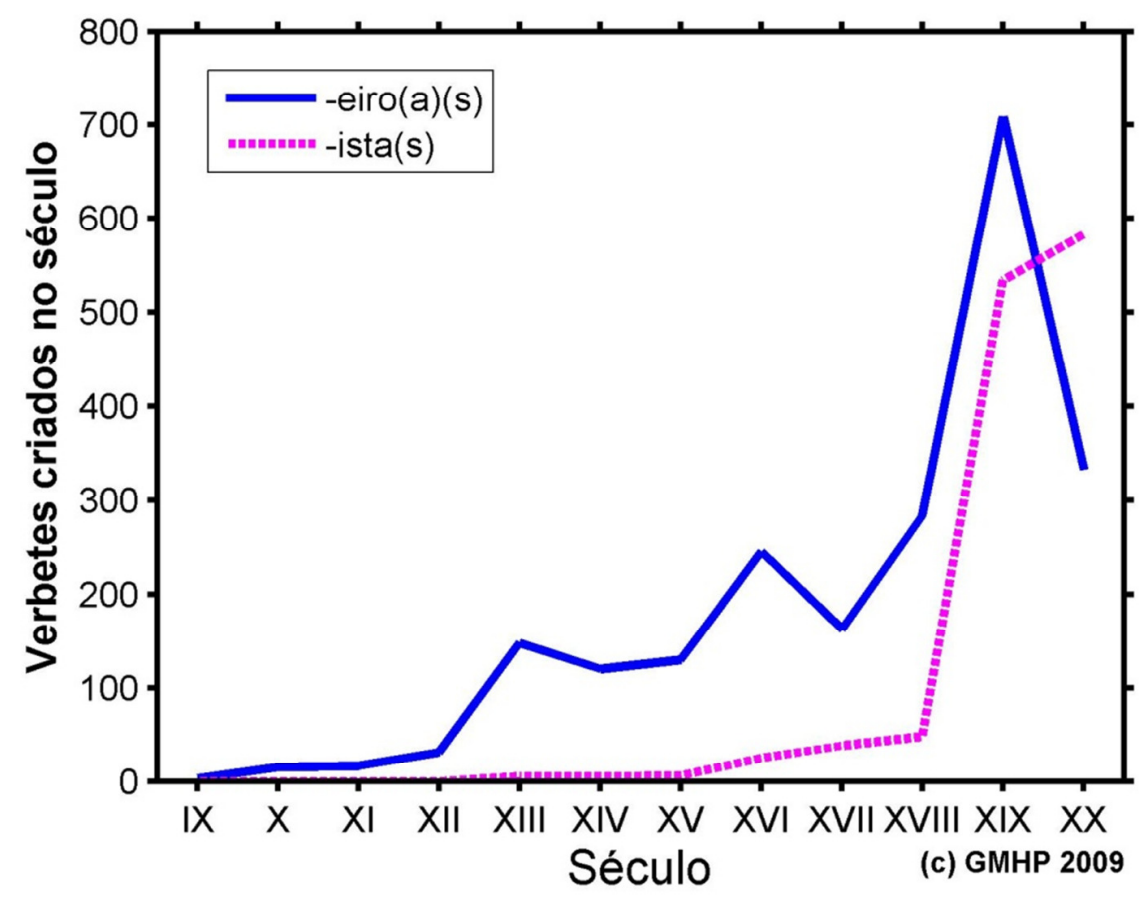

Gráfico 2: Produtividade absoluta dos sufixos -eiro(a)(s) x-ista(s)

Sufixos eventualmente usados em gírias de grupos muitas vezes têm alta produtividade, mas baixa prolificidade (como é o caso de -érrimo). Muitas vezes isso é um efeito de estilo, como podemos flagrar nos textos do escritor brasileiro Alexandre Ribeiro Marcondes Machado (1892-1933), nos quais seu heterônimo Juó Bananére usa com bastante frequência o pseudossufixo -imo: animo, por ano; viaduttimo, por viaduto; mesimo, por mesmo; barrimo, por bairro etc. Também pode haver elementos produtivos e prolíficos. Neste grupo, citem-se as terminações regulares da Morfologia Flexional.

O critério da produtividade não deve fundamentar a distinção entre flexão e derivação. Como as terminações flexionais têm altíssima produtividade lato sensu e o 
mesmo ocorre com sufixos como -inho, reconhecidamente derivacional, no português brasileiro, o parâmetro da produtividade de $100 \%$ não é justificativa para separar as duas áreas de estudo da Morfologia. Na área da derivação, produtividades com capacidade gerativa de $100 \%$ aparentemente só ocorrem quando não há concorrência de formas para expressar o mesmo significado: é o caso do sufixo -eiro para nomes de árvores. Em línguas aglutinantes como o turco, tais produtividades são comuns, pois ocorrem na maioria dos sufixos derivacionais (Jansky 1982).

As afirmações anteriores acerca da produtividade escondem alguns paradoxos, quando aplicadas. É fácil demonstrar que a produtividade se pode conhecer introspectivamente, ou seja, pela intuição fornecida pela competência do falante. Dessa forma, é possível, intuitivamente, como falantes do português, separarmos sufixos muito produtivos (-eiro, -ista, -inho), pouco produtivos (-engo, -uço, -eba), muito pouco produtivos (-ujo, -oncho) e improdutivos (-ádego). Essa separação também tem comprovação de sua verdade por meio da ferramenta operacional dos corpora. Já a prolificidade não é depreensível intuitivamente, uma vez que depende muito mais de investigações e cômputos a posteriori. Na verdade, a dificuldade que temos para a prolificidade, dado que um corpus não substitui uma língua a não ser metodologicamente, é a mesma que deveríamos ter para a produtividade.

Em ciência, sempre há a busca de amplos sistemas dedutivos baseados em formulações gerais, sobre as quais se criam regras particulares, obtidas por meio da introdução de variáveis, de modo que os casos dissidentes se revelam subcasos do geral. Em qualquer construto com escopo universal é relativamente fácil apontar exceções, uma vez criada alguma lei ou regra universal. No entanto, a existência de uma exceção quase nunca invalida uma teoria dedutiva, pois essa é, normalmente, comprovável num número colossal de dados. No entanto, as exceções são alavancas para o desenvolvimento científico. Uma teoria pode tornar-se frágil devido à mudança dos pressupostos epistemológicos, ao acúmulo de exceções, a variáveis desnecessárias e ao excesso de explicações ad hoc; no entanto, só perderá seu poder de convencimento quando for possível substituí-la por outra, totalmente distinta, com maior abrangência. Na história da 
ciência, uma simples evidência contrária, por mais forte que fosse, nunca derrubou nenhuma teoria. A busca da variável, portanto, costuma anteceder a busca de um novo modelo.

Observando neutramente o objeto de estudo da Linguística, veríamos que a língua estática é apenas uma miragem dos seus usuários que, normalmente, desconhece o seu passado e utiliza suas relações abstratas de forma pouco consciente para a comunicação. Um modelo que pressupõe uma língua estática entre seus pressupostos fundamenta a perspectiva da Gramática Tradicional, desde Dionísio Trácio. Isso não quer dizer que, sendo a língua inegavelmente dinâmica, não possamos falar de sincronia. A abstração que nos permite reconstruir uma sincronia é um procedimento científico - extremamente válido - para entendermos o funcionamento das línguas: antes de tudo, fundamenta um método e não é, portanto, um modelo per se, pois nenhum linguista suporia que a língua é, de fato, estática (Coseriu 1973).

No entanto, se a língua é dinâmica, uma linguística que pretenda descrever sua história, fará, na verdade, modelos sobre a essência da língua. A dinamicidade da língua é verificável tanto na ontogenia do falante - que fala diferentemente aos três e aos setenta anos - quanto na filogenia do sistema, pois palavras e estruturas passam, por imitação de indivíduo para indivíduo, de geração para geração, propagando-se de forma lenta, porém mais parecida com os modelos epidemiológicos do que propriamente com as árvores genéticas schleicherianas. Tudo que nos faz afirmar estarmos perante o mesmo sistema, dados dois indivíduos ou o mesmo indivíduo em duas etapas de vida, é, na verdade, uma abstração de inúmeros fenômenos. A identidade que garante os chamados sistemas linguísticos depende, muitas vezes, de fatores extralinguísticos, como, por exemplo, a história das populações que se servem deles e outros fatores ideológicos variados. Mesmo a intercomunicabilidade não é um elemento de fácil utilização para a caracterização das línguas. Nesse sentido, a fragmentação faz parte da essência das línguas (Schuchardt 1866-1868, 1885). O sucesso de uma palavra nova, sua expressividade e difusão é diretamente proporcional à capacidade de servir de molde para outras (Viaro 2007:45-47). 
Desse modo, não há paradoxo, nem desdouro ao articularem-se sincronia e diacronia: o recorte sincrônico é um método, já a descrição diacrônica flagra a essência de um ser específico, denominado língua, a qual, por sua vez é um objeto unificado pela nossa abstração. Segundo Rio-Torto (1997:215), "no estado actual de uma língua, há aspectos que não necessariamente se confinam ao conhecimento aduzido por uma análise exclusivamente sincrónica". Se estudar as línguas é investigar suas características e suas propriedades, a postura diacrônica jamais deve ser desconsiderada:

uma abordagem estritamente sincrónica pode distorcer ou falsear a interpretação da estrutura das palavras, pelo que a análise destas não prescinde duma simultânea consideração da sua história; sincronia e diacronia não são perspectivas disjuntas, mas complementares (Rio-Torto 1997:897).

O contrário também é verdade: quem investiga a diacronia deveria valorizar o estudo sincrônico. Da mesma forma que é preciso abstrair nosso objeto "língua" para começar a entendê-lo, deve-se abstrair o tempo em que esse objeto ocorre, por vezes, para estabelecer as etapas válidas em diacronia. No entanto, é necessário não perder de vista que nosso objeto de estudo é fruto dessas abstrações e não a própria realidade, como amiúde ocorre.

Paralelamente, o falante ideal, no sentido chomskyano, não pode ser nenhum falante real, o que seria uma contradição. Dessa forma, desde Platão, uma ideia é manifestada por meio dos seres individuais, portanto, nenhum indivíduo pode equivaler a uma ideia:

linguistic theory is concerned primarily with an ideal speaker-listener, in a completely homogeneous speech-community, who knows its language perfectly and is unaffected by such grammatically irrelevant conditions as memory limitations, distractions, shift of attention and interest, and errors (random or characteristic) in applying his knowledge of the language in actual performance. (Chomsky 1965:4)

$\mathrm{Na}$ literatura em português ocorre, por vezes, forte reação contra uma postura que proponha a reintrodução ou a validade do elemento diacrônico nos estudos sincrônicos, como em vários passos de Rocha (1998). Rechaçar o conhecimento histórico é uma postura isolada em ciência, que vem sendo corrigida em Linguística há cerca de vinte anos, 
sem o aproveitamento dos dados e reflexões das conquistas anteriores à decada de 20 do século XX. Não levar em conta a história, equivaleria à postura de um zoólogo que pretenda descrever a fisiologia dos animais e que ignore dados da evolução das espécies, imaginando a priori que o apêndice cecal humano, por exemplo, por não ter supostamente nenhuma função, seja algo que não precisa ser considerado nessa descrição. De fato, a evolução não teria importância para um modelo que pretenda entender uma função qualquer desse aparelho, como, por exemplo, a digestão, mas para a descrição do aparelho digestivo em si não faria sentido deixá-la de lado, tendo por base apenas esse aspecto pragmático, por mais importante que seja para a vida.

É inevitável observar que, na falta de uma língua real, um modelo de língua deveria pressupor sempre o elemento histórico, se visa à descrição da sua estrutura, a menos que entendamos por língua exclusivamente sua faceta pragmática e sua função comunicativa, componentes, aliás, muito importantes.

Outro aspecto que atrapalha sobremaneira o diálogo entre linguistas de diferentes linhas é a diversidade de conceitualizações. A variação semântica nos termos técnicos é muito prejudicial em qualquer ciência. Citemos o caso da nomenclatura zoológica. Para resolver o inextricável problema dos nomes científicos estabeleceu-se o ICZN (International Commission on Zoological Nomenclature, disponível em http://www.iczn.org), órgão internacional que se diz "Responsible for providing and regulating the system that ensures every animal has a unique and universally accepted scientific name". Em vigor desde 1895, utiliza-se o princípio da prioridade, contado a partir de um marco-zero: a data arbitrária de primeiro de janeiro de 1758 (referente ao ano da publicação da 10å edição do Systema Naturae de Carolus Linnæus e da obra Aranei Svecici, de Carl Alexander Clerk, artigo §1.3.1), definido e aceito universalmente. Toda uma legislação foi criada a partir das mais complexas situações que surgem. Questões como o país da publicação ou a língua em que foi escrita não contam na valoração de questões adjudicatórias, evitando-se, assim, correntes e modismos e, concentrando-se no fato a ser estudado. É verdade que esse código só vale para a Zoologia e não também para a Botânica (que tem um outro, independente). Tampouco leva em consideração 
nomenclaturas supragenéricas. Mesmo assim, as decisões em Linguística estão muitíssimo longe de algo tão bem organizado, pois a corrente e seus pressupostos são colocados, normalmente, em primeiro plano, os quais costumam ser esquecidos por escritos subsequentes 5 .

Uma análise historiográfica levada a cabo, segundo princípios semelhantes ao do ICZN, poderia auxiliar em problemas terminológicos básicos. Dessa forma, aplicado o princípio da anterioridade, sabe-se que a palavra homonímia já aparece nas Categorias de Aristóteles, já polissemia é termo criado por Bréal, no século XIX. O segundo termo, quando da sua criação, era aplicável sobretudo a questões diacrônicas, ainda que, posteriormente, isso só raramente tenha sido retomado, o que equivale a dizer que o termo técnico polissemia sofreu, ele mesmo, polissemia. Numa perspectiva sincrônica, dadas duas palavras $x$ e $x^{\prime}$ com mesma expressão (homofonia) e significados distintos, quais critérios deveria utilizar para afirmar que se tratam das mesmas palavras com acepções diferentes ou de palavras distintas? Modificar o significado de polissemia e homonímia, valendo-se da distribuição das formas, como em Câmara Jr (2005 ${ }^{37}$ : 27-29), não se revela, na prática lexicográfica, de grande aplicabilidade e, de fato, Biderman (2005) parece ter tido dificuldade em aplicá-lo. Sem o desenvolvimento de uma terminologia semântica que permita saber, para além da intuição do falante, quais palavras pertencem ou não ao mesmo campo semântico, o método proposto se torna ainda mais arbitrário do que o método histórico criticado por Câmara Jr. Tomemos, por exemplo, os sufixos e seu amplo leque de significados: trata-se de polissemia ou de homonímia? A discussão tornase estéril sem um princípio que norteie a terminologia. Para um observador que desconheça ou não leve em conta as sincronias pretéritas, a coexistência de sentidos gerados em outras épocas aparentemente é caótica. Por isso, houve até os que

\footnotetext{
5 Uma organização semelhante em Linguística seria um excelente expediente que evitaria a necessidade do estabelecimento de termos e sinonímias dependentes das correntes. Tampouco contariam idiossincrasias históricas ou políticas, as quais acabam por confundir as hegemonias com os núcleos de pensamento. $\mathrm{O}$ que falta, porém, para implementar-se um órgão internacional equivalente para a nomenclatura linguística é apenas um congresso unificado, se é possível estabelecer representantes do cipoal de correntes e linhas desenvolvidas, desde no século XX. Prevê-se que não seria de fácil consenso definir qual metalíngua utilizar (em Nomenclatura Zoológica, usa-se o latim científico desde o século XVIII). O maior problema, porém, certamente seria determinar o ponto-zero da Linguística.
} 
postulassem o assemantismo dos sufixos. Obviamente, o falante comum não consegue reconstruir o passado da língua que utiliza, pois isso cabe ao linguista. A língua funciona sem necessidade do conhecimento do passado e o pesquisador interessado na atitude pragmática do usuário pode abandonar o elemento histórico, se quer reconstruir o que se passa na mente do falante, mas, se o objetivo é classificar categorias e entender exceções, descrever a língua sem levar em conta esse elemento passa a ser uma atitude parcial. A rigor, pelo método historiográfico, o termo filosófico homonímia englobaria a polissemia, no entanto, tecnicamente falando, o termo polissemia exclui casos de homófonos nãopolissêmicos e somente esses poderiam ser denominados homônimos pela Linguística, de modo a justificar a oposição dos termos. Assim, perante dois ou mais fenômenos linguísticos homófonos, entendemos que há homonímia entre aqueles que não são remontáveis a alguma origem comum (no plano do significante equivaleriam às formas convergentes), por não haver nenhum terminus a quo conhecido, detectável ou reconstruível. Em oposição, há polissemia quando esse elemento comum no passado é rastreável. A dificuldade de se estabelecer o étimo não é uma deficiência metodológica, como quer Câmara Jr, ao querer invalidar a antiga oposição, mas uma deficiência resultante da localização dos dados e de sua organização. Aceitando, porém, a distinção feita acima, não se pode dizer que haja homonímia na variação de sentidos de -eiro ${ }^{1}$ para nomes de árvores, - eiro ${ }^{2}$ para profissões, -eiro ${ }^{3}$ para recipientes etc., uma vez que o conceito de polissemia lhes é mais adequado: trata-se do mesmo sufixo latino -arium, originalmente um formador de adjetivos, o qual inicialmente já tinha alguns sentidos básicos e desenvolveu, paulatinamente, novos sentidos nas línguas românicas (e alguns especificamente em português), uns sobrevivendo precariamente, outros com grande produtividade. A transformação semântica dos sentidos parafraseáveis a eles vinculados requer, contudo, pressupostos claros da semântica histórica (Viaro 2007).

A distinção ainda é útil para resolver problemas para os quais a intuição do falante não funciona. Por exemplo, a Linguística Histórica informa que -ário é a forma culta de arium, sufixo latino representado também pela sua forma popular-eiro. Isso, porém, é uma simplificação da questão, uma vez que em -arium há convergência de formas 
(homonímia), para além da polissemia do sufixo. Assim, palavras em -ar, -are; -al, -ale > -arium existem no corpus fornecido pelo dicionário Gaffiot (1934), como veremos no capítulo 5. Outro elemento que contribuiu para o obscurecimento do significado de arium foi a equivalência, motivada por semelhança fonética, de sufixos e terminações gregas. O mais importante de todos foi o sufixo -ápıov. Dessa forma, é necessário, no caso de sobrevivência, ao longo de diacronia, separar o que é de fato homonímico (ou seja, com origens distintas) do que é polissêmico (com mesma origem).

No sentido definido acima, há ainda outros casos: o sufixo-agem, por exemplo, é uma forma convergente do-aginem latino e do -age provençal e francês < latim -aticum (Gonçalves 2009). Os homônimos, contudo, não se confundem com os pseudossufixos, desse modo, macaxeira provém do tupi makaxéra e não possui, de fato, o mesmo sufixo de pereira < latim * piraria, apesar de serem ambos plantas (cf. roseira). Para o usuário da língua portuguesa, o -eira da primeira palavra em nada se distingue do segundo. A opacidade do pseudorradical macax- não é obstáculo para essa identidade (cf. chiqu- de chiqueiro, quando se depreende o -eiro "local onde se guarda X", como em galinheiro). Por outro lado, dizer que a terminação-eira de macaxeira é um sufixo, do ponto de vista diacrônico, é falso, pois não possui o mesmo étimo ou terminus a quo de pereira. Na verdade, nesse caso, está claro que, para o uso, não importa a história, e pode faltar o elemento diacrônico entre os pressupostos de um modelo sincrônico com vistas à compreensão da comunicação. Para a descrição das palavras terminadas em -eiro, contudo, omitir a informação de que aí houve convergência seria colocar o recorte metodológico acima de um pressuposto mais básico: o de que a língua é dinâmica, como já vimos. Ora, o recorte e seus pressupostos só podem ser feitos após estabelecerem-se esses pressupostos mais básicos e, uma vez que ninguém nega que a língua se modifica com o tempo, o pesquisador interessado em descrevê-la não pode deixar de citar tais problemas de origem e de separar esse caso particular, para, posteriormente, fazerem-se classificações e investigações acerca do fenômeno da convergência semântica, que é comprovável também indiretamente pelo indício da grafia analógica (macaxeira, com ditongo, e não *macaxera). 
Outro fenômeno que se destaca quando o elemento diacrônico é envolvido é o caso do arcaísmo. Por exemplo, como vimos, o -arium diminutivo provém da terminação homônima grega -ápıov e não é derivável por polissemia do sufixo latino -arium. Uma palavra como stillarium "gotinha", porém, proveniente de stilla "gota" é demonstração de que o significado diminutivo do sufixo grego se encontra já produtivo no período clássico. Esse uso do -arium diminutivo desapareceu completamente no português, com exceção de igrejário "pequena igreja", que se revela um verdadeiro arcaísmo. Essa palavra mostra que o -ário diminutivo, no português atual, é raro (prolificidade=1) e improdutivo (produtividade $=0$ ). Não se formam mais palavras diminutivas em -ário, donde o desconhecimento de sua existência, da parte dos falantes. Sem o elemento histórico, sua paráfrase pareceria uma exceção inexplicável. Dessa forma, um sentido pode estar presente num único testemunho (hápax), apesar de, na época de sua criação, ter havido certa produtividade. Não se podem excluir esses casos excepcionais, sem uma investigação aprofundada ${ }^{6}$.

Nem todos os elementos excepcionais são, contudo, do mesmo tipo da palavra igrejário. Pode-se afirmar que toda exceção é uma contradição às declarações genéricas de um modelo científico e, portanto, sua simples existência o deixa em suspenso. Ficará nessa situação, até que uma variável seja encontrada, a qual, associada ao modelo, consegue torná-lo mais refinado. A associação do modelo com a variável deve fortalecê-lo, de modo que deve passar a explicar não somente a exceção, mas também prever vários outros casos descobertos pela primeira generalização. Às vezes, para retirar o modelo da suspensão, em vez de uma variável, introduz-se algum elemento ad hoc até o aparecimento de melhor solução, o que, não raro, não ocorre, deixando-se o modelo remendado. No entanto, essa última postura, apesar de funcionar provisoriamente, tem pouco valor científico (Hessen 1926; Hegenberg 1969).

Perante modelos com um número grande de exceções, a epistemologia mostra que inexoravelmente duas soluções se preveem: ou (1) mantém-se o modelo, que se sustenta,

\footnotetext{
${ }^{6}$ O porco-da-terra ou aarvark, cujo nome científico é Orycteropus afer (Pallas, 1766) é o único representante da ordem dos tubulidentados, o único da família dos oricteropídeos e o único do gênero Orycteropus, embora tenha havido comprovadamente outras famílias, gêneros e espécies em outros momentos da evolução. Não faria sentido excluí-lo do estudo mastozoológico, por causa dessa peculiaridade.
} 
por apego ou tradição, por meio de regras ad hoc; ou (2) questionam-se os pressupostos, refazendo-os de maneira tão profunda, que nada do modelo anterior é aproveitado. Um modelo é perfeito, pois sempre haverá exceções, mas um modelo com número menor de exceções é preferível a um que só se sustente por meio de um número infinito de variáveis e regras ad hoc, apesar do ilusório aspecto de complexidade, como ocorria em muitas questões da escolástica medieval. A reformulação teórica alavanca, em curto prazo, a total destruição da teoria anterior ${ }^{7}$. Por um momento, duas teorias para o mesmo fenômeno podem conviver, mas uma delas está fadada a desaparecer, não por capricho, esquecimento, ou acidente histórico, mas por incompatibilidade, ao se ampliar o escopo do objeto estudado. A maior razão disso advém de pressupostos antagônicos.

As exceções existentes nos estudos de língua tendem a agrupar-se em listas nos modelos. Por isso, encontram-se as listas de exceções da gramática tradicional e mesmo as palavras complexas no Léxico, dos modelos teóricos do Gerativismo (cf. Chomsky 1970) têm por base esse mesmo princípio ordenador. Também em estudos históricos, as exceções aos metaplasmos são problemas normalmente reinterpretados à luz da analogia. Nos estudos que privilegiam a sincronia, as exceções são explicadas, por vezes, por meio da solução do efeito de bloqueio (Aronoff 1976) que requer afixos idealmente

${ }^{7}$ No século XVII, um grande problema era o de como Noé teria levado todos os animais do mundo numa arca com as dimensões apresentadas na Bíblia (aproximadamente 198m. de comprimento, 33m. de largura e 19,8m. de altura). A miríade de animais que povoavam os museus, advindos da América, África e Ásia desde o século anterior ofereciam, contudo, uma contradição à teoria e problemas inéditos ao dito bíblico. A explicação dada pelo jesuíta alemão Athanasius Kircher na sua obra Arca Noe in tres libros digesta (Amsterdam: Joannis Janssonium à Waesberge, 1675) foi muito bem recebida. Sua argumentação: os animais aquáticos não precisavam obviamente ser levados na arca, tampouco os anfíbios e os invertebrados, pois nasciam por geração espontânea, conforme os pressupostos da época. Portanto, nela transportaram-se somente mamíferos e aves, o que ainda era muito. Noé teria levado apenas alguns animais (os arquétipos), os quais, uma vez estacionada a arca, se cruzaram entre si, dando geração aos animais atuais, que seriam híbridos desses arquétipos. Por exemplo, a girafa proviria do cruzamento do camelo com o pardo (animal citado por Plínio), da mesma forma a marmota seria o cruzamento do esquilo com o texugo; o tatu, do ouriço com a tartaruga; o leopardo, do leão com o pardo etc. Para todas as espécies conhecidas, Kircher necessitava apenas de 196 arquétipos, número que podia perfeitamente ser levado por uma arca com as dimensões bíblicas (Papavero et al., 1997). O modelo era perfeito para a época. Era elegante e garantia a verdade dos pressupostos vigentes (a existência da arca e do Dilúvio, a auctoritas da Bíblia de de Plínio). Posteriormente ao se verificar, contudo, o problema da esterilidade dos híbridos e a falácia da geração espontânea, a hipótese de Kircher se tornou insustentável. Uma teoria cujos pressupostos se fragilizam não consegue ser infinitamente remendada por argumentos ad hoc. Num determinado momento, todos seus pressupostos foram questionados, abrindo-se caminho para a teoria de Darwin-Wallace (1859). Algo semelhante ocorreu quando Copérnico e Galileu defenderam a teoria heliocêntrica contra o consagrado geocentrismo: não se trata apenas de uma comutação dos elementos envolvidos. 
monossêmicos. Dessa forma, uma palavra formada com radical $x$ e sufixo $y$ é bloqueada se já houver, de antemão, uma outra com o mesmo radical $x$ e sufixo $z$, sendo $z \neq y$, do ponto de vista do significante, mas $z \cong y$ do ponto de vista do significado. No entanto, esse efeito é relativizado pelo fato de a língua ser, na realidade, um conjunto de variedades, como alertado pela Sociolinguística moderna, o que promove sensíveis mudanças no modelo. A língua real não apresenta a invariabilidade de caráter platônico de alguns modelos seiscentistas e setecentistas, cujos princípios também estão presentes no gerativismo (Chomsky 1959; 1965; 1966; 1975).

$\mathrm{O}$ argumento a favor de uma produtividade total em Morfologia, diferentemente do que ocorre na Sintaxe, se restringe a casos muito específicos, sendo excepcional nas línguas flexivas. Desse modo são raras, como vimos, as regras regularmente aplicáveis, sem concorrência e com poucas restrições. O mais comum, nas línguas flexivas é a abundância de exceções, parcialmente explicável pelo estudo diacrônico.

Diacronicamente, a terminação -eiro de primeiro tem o mesmo étimo do sufixo eiro em abacateiro ou em caminhoneiro, o que justificaria falarmos de polissemia, como vimos. Comumente, porém, não se costuma considerar o primeiro caso e os dois últimos são tidos como homônimos. Ou seja, negam-se muitos casos excepcionais em nome do recorte sincrônico, que se pauta no julgamento do falante nativo.

Com relação ao recorte, é preciso que alguns paralelos sejam feitos. A Mastozoologia não negaria aos monotremados seu status de objeto de estudo, por serem excepcionalmente os únicos mamíferos ovíparos atuais, característica ausente nos demais mamíferos. Haverá especialistas mastozoólogos nesta ou naquela ordem (ou mesmo nesta ou naquela família, gênero ou espécie), mas nenhum recorte particular feito por qualquer mastozoólogo excluiria os monotremados da condição de objeto de estudo da Mastozoologia ou de suas generalizações. Similarmente, fazer um recorte não é o mesmo que negar fatos e deixá-los inexplicados. O linguista deve, portanto, reintroduzir as exceções nos modelos mais gerais e somente fazer um recorte em modelos específicos, sob pena de, fazendo o contrário, excluí-las de quaisquer outros modelos possíveis. Para tal, parece-nos que o primeiro passo, porém, deva ser necessariamente indutivo. Não só o 
sufixo -eiro de primeiro reassumiria, desse modo, sua posição dentro de uma classificação semântica que preveja a diacronia, mas toda informação recuperável do sufixo latino arius deveria estar lá incluída, a despeito de participar de outro sistema (Viaro: 2006, 2007). Desse modo, desconsiderando o sufixo -eiro de primeiro, por negar-lhe o fato de que pertença ao mesmo conjunto que outras palavras em -eiro. colocamo-lo, em nome de um recorte, junto com os pseudossufixos. Diacronicamente, porém, isso é falso.

Além disso, não seria razoável para a Mastozoologia desconsiderar o lobo-datasmânia do estudo taxonômico simplesmente pelo fato acidental de ele estar extinto, como se dele não tivéssemos absolutamente nenhuma informação, como se fosse um animal lendário, cuja existência não pode ser comprovada. No entanto, é comum não se aproveitar quase nada da vasta bibliografia novecentista (ou anterior) da Linguística, no tocante a variedades que hoje já não existem, simplesmente por alegar-se que não havia método nas interpretações dos dados nos períodos chamados pré-científicos. No entanto, o que soaria contraditório, muitos dados realmente não-existentes são importantes para a Linguística: as criações virtuais de regras produtivas, por exemplo. Se elementos de sincronias pretéritas e de outras variedades diastráticas e diatópicas não têm o mesmo status de formas agramaticais, não se justifica, portanto, sua negação.

A palavra chuveiro é perfeitamente segmentável sob uma ótica sincrônica, mas há algo que complica na sua análise. Se é fácil ver nela a base chuv- e um sufixo-eiro, qual seria a paráfrase a ser feita? Se alguém dissesse que é "objeto por onde sai a água de modo que lembra uma chuva", tal paráfrase ad hoc seria única, o que nos faria pensar que estamos diante de um hápax, como em igrejário. Outra solução seria a hiperonímia: nesse caso, dir-se-ia que -eiro se refere a objetos e a paráfrase teria pouca utilidade: chuveiro deixaria a condição de hápax e faria parte do mesmo conjunto de que participam chaleira, cafeteira etc. Que nenhuma das soluções seja ideal confirma o dado histórico, uma vez que as primeiras abonações de chuveiro remetem a uma chuva forte (sentido ainda verificável diatopicamente, mas desconhecido da fala de muitos falantes) e não a um objeto. Em Frei Luís de Sousa (1631 Anais de Dom João III) se diz "Cessou aquele espanto e terror; mas logo sobrevêo outro, que foi um chuveiro de água tao grossa e tao 
extraordinária". Em suma, quando a palavra foi criada, chuveiro tinha o mesmo sentido do sufixo de nevoeiro, ou seja, "X intenso". De fato, o objeto chuveiro é nada mais que uma metáfora do sentido mais antigo de "chuva forte" e é a partir desse significado da palavra que se deve partir, numa tipologia, ainda que seja arcaico ou regional para o linguista que o analisa. Dessa forma, um modelo linguístico não deve ignorar a informação diacrônica e a variação diatópica na sua análise, para evitar a solução ad hoc, ou seja, deve levar em conta o momento da criação e não um significado qualquer, obtido mediante introspecção ou experiência particular. Pode haver divergência na interpretação dos dados, mas o relativismo científico deve ser entendido como um problema resultante da interpretação dos dados - e da totalidade de informação que temos deles - e não da

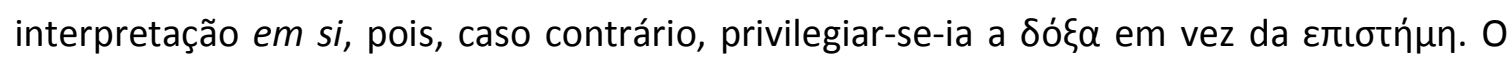
fato de assim não ser feito, por exemplo, no caso de chuveiro, se dá ou porque o analista não conhece esse significado (e assim respeita exclusivamente a sua intuição de falante) ou porque o considera anacrônico, por estar numa época que julga passada, a despeito de haver falantes (de outras regiões ou de outras classes sociais) que ainda usem a palavra na acepção original. Se, porém, o escopo da pesquisa é a própria língua e não sua função comunicativa, o linguista deve voltar-se a quaisquer dados para buscar os porquês das idiossincrasias, da mesma forma que o taxonomista deve buscar dados nos fósseis e em animais extintos preservados em museus para entender aspectos evolutivos, fisiológicos ou mesmo etológicos. Os tipos envolvidos nas descrições biológicas são classificados, descritos, conservados em locais acessíveis ao especialista, divulgados em revistas que as catalogam e julgam e, por fim, são discutidos. Os dados linguísticos, no entanto, raramente passam por todas essas fases. Uma palavra sufixada, numa dada sincronia, que forme um hápax semântico não é prova do assemantismo ou de excesso de arbitrariedade semântica dos sufixos, mas um fato a ser investigado.

Resumindo, uma Morfologia descritiva deve incluir o elemento diacrônico na paráfrase de cada elemento substituindo intuição do falante nativo ingênuo pela reconstrução do significado no momento da criação. A dificuldade de se obter esse elemento não é menor que a do outro. Também outras ciências, como a astronomia 
trabalham com objetos de estudo praticamente inescrutáveis. Para isso existem os modelos científicos.

Um pressuposto muito caro ao Gerativismo é a questão da competência do falante para julgar sobre sua própria língua. Ora, isso é perfeitamente possível dentro de uma perspectiva estritamente sincrônica, uma vez que o falante continuamente toma decisões na decodificação, pautado justamente nessa capacidade que tem, em última instância, suportes cognitivos.

Chomsky (1965:4-5) define competência como "the speaker-hearer's knowledge of his language". Dessa premissa deriva a sua definição de gramática, a saber, "a description of the ideal speaker-hearer's intrinsic competence". Em outra obra, após a mesma formulação, explica que "we may (...) think of the study of competence as the study of the potential performance of an idealized speaker-hearer who is unaffected by such grammatically irrelevant factors" (Chomsky \& Halle 1968:3). Nos anos seguintes, buscouse ampliar o escopo dos modelos linguísticos, haja visto, como se subentende nos dizeres do próprio Chomsky, as comunidades não são homogêneas, os falantes não têm conhecimento integral da língua, a memória tem restrições, sem falar da importância para um modelo cognitivo da linguagem, da atenção, dos lapsos e das crenças.

Paralelamente, o conceito chomskyano de competência deu ao falante poderes inéditos, como o julgamento da gramaticalidade (Chomsky 1957:13-17). A gramaticalidade, segundo o gerativismo, pertence ao estudo da competência, enquanto a aceitabilidade se restringe à performance (Chomsky 1965:3-15). O julgamento da gramaticalidade instaurou uma nova metodologia que, apesar de útil para diversos fins, é um pressuposto incompatível com a perspectiva diacrônica, pois não é possível aplicá-lo nas sincronias pretéritas ou mesmo em outras variantes não dominadas pelo analista. 0 que o falante sabe sobre sua língua, na verdade, não importa muito, para uma descrição da língua, dada a complexidade desse objeto de estudo. Medir o grau de domínio da língua do analista ou alguma dimensão de sua reflexão metalinguística é importante para questões sobre seu funcionamento, mas as verdades universais só parcialmente dependem do observador e modelos de descrição linguística pretendem reproduzir sua 
essência, que transcende a experiência empírica. Ademais, é sabido que todo cientista deve ter um grau de distanciamento em relação ao seu objeto de estudo, sob pena de nele fazer transferências ou injunções.

Nos anos que antecederam o gerativismo, tal postura era, até mesmo, posta sob suspeição: "the decision rests with the native speaker of the language, and to this extent the description of any language will be subjective" (Nida 1949: 56-57). De fato, o falante é apenas um observador de sua língua, sem nenhum conhecimento para além da sua experiência e pode, involuntariamente, falsear muitas conclusões, como amiúde se vê nos testes de gramaticalidade ou em questões etimológicas.

A língua enquanto "fenômeno complexo que funciona com a finalidade comunicativa intra e intersubjetiva" e a língua enquanto "conjunto de signos, palavras e regras, herdado e transmitido com modificações imperceptíveis entre os falantes de uma comunidade" poderia, aliás, ser objetos de estudo de ciências distintas. Uma ciência que se dedicasse à primeira procuraria compreender como se dá a comunicação e a cognição, poderia ignorar a diacronia e focaria a pragmática, ao passo que uma ciência voltada à segunda buscaria explicar a estrutura linguística, a qual não foi formada de uma vez só e, portanto, não poderia prescindir de dados históricos. Seriam, portanto, tão distintas como o são a Medicina e a Biologia. De qualquer forma, nada justificaria, porém, o desconhecimento mútuo, da mesma forma que Química e Física precisam dialogar em seus modelos para não caírem no solipsismo teórico. Criticar reciprocamente o objeto de estudo, como já se presenciou em muitos momentos da História da Linguística, seria algo como um zoólogo criticar um botânico por estudar plantas e não animais: essa separação dos seres vivos só se faz necessária devido às suas diferenças estruturais e, em grande parte, à tradição da Biologia. Se o entendimento do funcionamento da fotossíntese é interessante, mas não para um zoólogo, o mesmo não se pode falar dos elementos comuns a plantas e animais, como as células.

Por mais caro que seja o conceito de competência a questões sincrônicas, não se encontra entre os pressupostos de questões diacrônicas e, em particular, para estudos 
sobre a produtividade. Forçar uma síntese, nesse caso, gera contradição, provocando, em muitos momentos, um non sequitur nas argumentações.

Conceitos como nomes, verbos, derivação, sufixos e desinências, usados pela Linguística de viés sincrônico ou diacrônico, foram herdados da gramática tradicional, reformulados e redefinidos pelas teorias exsurgentes. Na historiografia, portanto, se devem procurar os pressupostos sobre os quais se erigem teorias linguísticas e seus inúmeros modelos.

Como vimos, há muitas formas de entender a produtividade, mas raramente as divergências epistemológicas são elucidadas e, por isso, não é difícil confrontar-se com paradoxos: se a língua, por definição, fosse apenas um léxico com algumas regras, nenhum movimento na língua deveria ser perceptível, para além da geratividade sentencial. Dessa forma, a ideia de derivação em Morfologia seria, por si só, paradoxal e discutir questões como a da produtividade nem ao menos faria sentido. Se, porém, nessa língua se admite a derivação, mas não a transformação diacrônica, o escopo de tal modelo aparentemente só satisfaz problemas de línguas mortas ou de línguas artificiais, pois a cada novo elemento lexical, sempre se aplicariam as mesmas regras. Ora, as línguas reais vivas têm variedades, alteram-se com o tempo e acumulam, de modo estocástico, todo tipo de regra, produtiva ou não.

É bastante conhecida a passagem dos modelos de item e arranjo, para os de item $e$ processo e, por fim, os de palavra e paradigma (Spencer 1991: 49-56); no entanto, não deveria ver-se nessa sequência nenhum progresso (aliás, sequer é uma cronologia), o que pode fazer confundir a passagem do tempo com uma evolução do saber. À medida que se aceitavam as transformações, abandonava-se a visão diacrônica. Perante pares como groom/bridegroom, sand/sandblind, fake/fakir, noise/noisome, Nida (1949:56-57) afirma que "such data are in conflict with the history of language, but are pertinent to a descriptive analysis". Nida, sem negar a história, não a considerou apenas por finalidades metodológicas. Em contrapartida, a integração entre história e descrição é buscada hoje com muito empenho, mas, sem muita revisão de conceitos, talvez por ainda haver poucos pesquisadores que transitem pelos dois campos. 
Como dissemos, a introspeç̧ão não consegue substituir a investigação dos dados, pois a primeira se volta para o aspecto funcional da língua e a segunda, para o tipológico. Introduzir a competência entre os pressupostos de um modelo equivale à disponibilização de um elemento subjetivo altamente poderoso, como o bom-senso: algo inédito em qualquer ciência.

O bom-senso nos diz, por exemplo, que seres com formato semelhante devem ser classificados juntos, mas a Biologia não se deixa levar pelo epifenômeno da aparência, que é, antes de tudo, mero julgamento pautado nos sentidos humanos. Se assim agisse, agruparia - dadas as semelhanças de alguns órgãos que funcionam como nadadeiras focas, peixe-bois, baleias, pinguins, o extinto ictiossauro, lampreias, tubarões e sardinhas (ou seja, mamíferos, aves, répteis, ciclostomados, condrícteos e osteícteos). A verdade científica, porém, normalmente busca transpor o bom-senso. Alguns insetos podem parecer muito semelhantes entre si (por exemplo, nos casos de homoplasias por convergência), embora essas características comuns revelem, muitas vezes, evoluções distintas. Isso ocorre em espécies distintas ou mesmo entre famílias ou ordens, pois é a evolução dos caracteres que conta e não os caracteres em si. Por exemplo, entre os insetos, os mantídeos, os mantispídeos e os efridídeos dos gêneros Ochthera e Stenochthera desenvolveram independentemente uma função raptorial do primeiro par de patas que Ihes confere uma aparência muito similar, contudo, tais insetos pertencem a ordens totalmente distintas e não possuem ancestral comum com essa característica. Num estudo científico, a semelhança dos fenômenos, apesar de nortear a cognição humana, cede lugar a elementos mais significativos, muitas vezes pouco óbvios: no caso da Biologia, à fisiologia, à ontogenia, à embriogênese, ao estudo das genitálias, ao genoma; na Linguística, ao étimo e às palavras aparentadas em outras línguas ou às variantes não necessariamente do domínio do analista. Resumindo, o que conta é o objeto e não o sujeito percipiente. Para atingir verdades acerca da essência da língua é necessário investigar fontes ou fazer testes e não usar a introspecção cartesiana, que remonta a uma experiência individual ou a erros interpretativos que fogem do objeto em si. 
O falante nativo, julgando apenas pelo seu bom-senso, tem direito de, por exemplo, afirmar erroneamente que uma palavra da linguagem coloquial (por exemplo, legal no sentido de "muito bom") seja um neologismo, mas, numa situação ideal, respaldado por bancos de dados organizados que pudesse consultar nos momentos de dúvida, um cientista da linguagem, cercado de toda informação sobre a mesma palavra, não deveria fazê-lo jamais e se o faz, revela a situação precária em que se encontram os dados sobre os quais generaliza e teoriza. Não há, de fato, um equivalente ao Zoological Records para a Linguística, mesmo os corpora em projetos excelentes que visam a uma centralização da informação, como a Linguateca (http://www.linguateca.pt/) estão ainda longe de se lhes equipararem, antes são um primeiro passo.

Dever-se-ia pensar em quanto realmente os novos modelos superam os anteriores. Todos sabemos que o trabalho feito pelos historiógrafos nos têm revelado nomes esquecidos e, não raro, algumas surpresas. Foi assim que se redescobriu que Gyarmathi (1799) foi anterior a Bopp (1816) nos estudos comparativos; que o indiano Pāṇini (VI a.C.) antecedeu em seu Aștāâhyāyī, em muito tempo, a gramática transformacional; que Fernão de Oliveira (1536) já utiliza metodologia estruturalista e que Kruszewski (1881) em muitos pontos antecipa os mais brilhantes momentos do Cours de linguistique générale (1916). Na falta de um princípio da prioridade, semelhante ao do CINZ porém, a figura do precursor é mera curiosidade. Abundam ainda "marcos de cientificidade" que, supostamente, teriam colocado alguma ordem no caos anterior. Somado a isso, algo parecido com o princípio medieval da auctoritas refreia novas revoluções. Finalmente, muitas vezes, a crença numa suposta evolução das ideias se fez crer por manuais de historiografia no período do pós-guerra de qualidade duvidosa (como o de Leroy 1964).

Falta, não só uma metalinguagem acima das correntes (como o nome científico em Biologia e Botânica), mas uma série de definições consensuais que diminuam a excessiva polissemia na terminologia linguística. Já houve tentativas nesse sentido (Bloomfield 1926), mas a aceitação unânime dessas ferramentas aparentemente só funcionou, até agora, com o IPA, que, aliás, substituiu, sem superar em qualidade, o alfabeto de Lepsius (1863). Sem as definições e metalinguagem próprias, é custoso saber se os autores tratam 
do mesmo fenômeno ou não. Aparentemente o relativismo sempre é invocado para oporse a essa crítica. Uma vez aceita a dinamicidade da língua, muitas outras premissas se seguem. Toda língua compõe-se, por exemplo, de um léxico e de regras, os quais foram construídos por falantes, ao longo de muito tempo. Desse modo, como mostra o estruturalismo, cada sistema é independente. No entanto, parte significativa do léxico transita entre várias línguas, graças aos fenômenos do empréstimo (por contato ou por prestígio) e do poliglotismo. A oposição herança x empréstimo, assim, se tornará fluida se, a partir do léxico de duas línguas quaisquer, se abstrairem elementos que possuam origem comum. De fato, um elemento lexical qualquer, a despeito das idiossincrasias fonéticas e semânticas que adquire do sistema a que se vincula, pode ser compreendido e descrito em toda sua completude, prescindindo-se a priori de considerações sobre se pertence ou não a um dado sistema. Não importando quais sentidos particulares adquiriu numa língua específica, a mesma palavra, que está em outra língua, traz em si informação que o linguista não deve desconsiderar. Ora, sabe-se que a preservação de formas é dependente do tipo de classe que as inclui no sistema: artigos, preposições e pronomes são reconhecidamente mais conservadores, ao passo que nos substantivos, verbos, adjetivos e até numerais são bastante comuns os empréstimos. A classe tradicional dos advérbios tem ambas as características, dependendo do subconjunto enfocado. A maioria das conjunções não se encaixa necessariamente no primeiro grupo, uma vez que têm grande capacidade de remodelação intersistêmica.

Para uma morfologia que leve em consideração o elemento diacrônico, é de relevância não só a história das classes, mas também a das unidades morfológicas, as quais podem perpassar sistemas diacronica- ou diatopicamente. De um ponto de vista metodológico, numa descrição dos fatos morfológicos, é secundária a compreensão de como ocorre a reunião desses elementos, numa sincronia qualquer, para os fins comunicativos que serve, no entanto, a investigação semântica desses elementos necessitaria de descrições sincrônicas, que são in fine construtos ideais, mas não a língua per se, a qual envolve muitas sincronias e variedades. 
Da mesma forma que é indiferente para a Biologia lato sensu se uma pesquisa específica trata de Etologia, Ecologia ou Taxonomia, o recorte do linguista não diz muito à Linguística lato sensu. No entanto, não compreender isso já foi motivo de desentendimentos entre correntes e seguidores. Após a década de 50, ampliou-se o discurso a favor de um estudo sincrônico em detrimento do diacrônico. Hoje vemos trabalhos em que as perspectivas sincrônica e diacrônica convivem (Hopper \& Traugott 1993; Bybee \& Hopper 2001; Kroch 2001; Heine \& Kuteva 2002; Silva, Torres \& Gonçalves 2004). Isso se dá porque esses eixos não são modos opostos de encarar um mesmo objeto de estudo, pelo contrário, revelam objetos completamente distintos. Os modelos que podem prescindir da diacronia parecem mais adequados para explicar fenômenos que envolvam a comunicação, a cognição e aspectos pragmáticos. No entanto, para entender o funcionamento da língua, para fazer a descrição de sua estrutura, para entender a neologia e a produtividade, o elemento diacrônico se revela imprescindível. $\mathrm{O}$ salto da indução para um modelo dedutivo, desse modo, ainda não se efetivou completamente. No entanto, uma nova Linguística que focalize a essência do fenômeno chamado "língua" deverá surgir dialeticamente por entre as escolas, com metalinguagem e método próprio, questionando posturas dogmáticas, restaurando ideias perdidas e alertando para a incompatibilidade de algumas ferramentas. 


\section{A QUESTÃO DA EXISTÊNCIA DE UM SUFIXO}

Do ponto de vista sincrônico, um sufixo derivacional numa língua flexiva, como o português é facilmente depreensível, quando ambas as partes da segmentação (radical e afixo) são reconhecíveis. Desse modo, sapateiro, teria um radical sapat- e um sufixo derivacional -eiro, que aparecem em outras situações, em que se reconheceriam os mesmos elementos com o mesmo sentido: sapat-ilha, cozinh-eiro etc. Às vezes, porém, essa situação ideal se torna complicada. Por exemplo, o sufixo -eiro, nos dois casos acima (sapat-eiro, cozinh-eiro) apontaria para o campo semântico das profissões, como em pedreiro, no entanto, nesse último exemplo existe uma transparência menor na base. Apesar disso, o significado é o mesmo: "(pessoa) que $V X$ ", sendo $V$ um verbo qualquer (aqui, algo como "trabalhar com") e X a palavra representada ou evocada pela base presa ("sapato" devido a sapat- em sapateiro e "pedra" devido a pedr- em pedreiro). Porém, se é óbvio que um sapateiro trabalhe com sapatos, não é tão óbvio, do ponto de vista sincrônico, que um pedreiro trabalhe com pedras, ao menos não exclusivamente com elas. Também sapateiros trabalham com sandálias, tamancos, tênis e outros calçados.

Sabe-se que o mesmo significante de um sufixo pode ter vários significados parafraseáveis e os estudiosos divergem quanto a considerá-los como casos de polissemia ou de homonímia. Além disso, nem sempre o radical é transparente o suficiente para fazermos uma paráfrase. Para o mesmo significado "local onde se guarda X" temos chiqueiro, onde $\mathrm{X}$ é mais opaco que em galinh-eiro: trata-se de um típico morfema cranberry (termo corrente na Morfologia e baseado na argumentação de Bloomfield 1933: 160; cf. Štekauer, 2000: 141). A dificuldade de se fazer a paráfrase se acresce às vezes à técnica da comutação: em prim-eiro (comumente nesses casos se contesta a própria segmentação, embora haja a possibilidade, segundo alguns procedimentos teóricos, de o compararmos com terc-eiro).

A falta de transparência na composicionalidade parece completa quando o significado total não se depreende. Isso ocorre tanto em palavras que, vistas superficialmente, parecem não indicar absolutamente nada da soma das suas partes 
(como no inseto barb-eiro) ou quando tanto radical quanto o suposto sufixo são opacos (macax-eira, jan-eiro, int-eiro). O que se observa nisso tudo é que a análise de uma terminação que adquire o status de sufixo é bastante subjetiva, do ponto de vista puramente sincrônico.

Como já dissemos, nas atuais bases teóricas mais correntes autoriza-se o falante nativo a fazer julgamentos sobre a própria língua que fala. Se essa posição não tomar ares dogmáticos, é possível imaginar uma relativização desse pressuposto. De fato, a língua particular desse falante-juiz (que costuma ser, quase invariavelmente, um linguista ou alguma pessoa com bagagem teórica formal acima da média da população) é, de fato, apenas um exemplo parcial da língua que supõe falar. Não sendo exclusividade de nenhum falante, o que se costuma chamar de "língua" é sabidamente um ser heterogêneo. Dado que uma língua é a soma de todas as línguas particulares de seus falantes, é preciso afastar-se do subjetivismo em se tratando de estudos cuja meta não é necessariamente entender como a comunicação se efetua nessa língua, mas descrever os instrumentos sobre o qual ela se alicerça. Destituindo a figura do falante-juiz, um falante poderá, às vezes, corroborar um fato linguístico e não de dar o veredito sobre elementos do sistema (Viaro 2005, 2007, 2010b). Se não for assim, os argumentos linguísticos pertencentes a sincronias pretéritas e a variantes distintas das usadas pelo falante-juiz não seriam analisáveis, já que os enunciadores não estão presentes ou não podem simular ser o outro para fazerem o teste do falante nativo.

De fato, é preciso ter em mente que a língua enquanto instrumento de comunicação pode desconsiderar completamente a diacronia e focar em estudos mais voltados à psicologia. Já uma linguística preocupada com a explicação dos fatos da língua não pode ater-se apenas à sincronia atual e teria de falsear dados se o fizesse, uma vez que todos sabemos que a essência das línguas é mutável diacronicamente, como se flagra no intervalo de uma vida. O eixo sincronia-diacronia, portanto, é falacioso por ser assimétrico: uma "sincronia" nada mais é que um recorte, feito com fins práticos e metodológicos. Já uma "diacronia" flagra algo essencial da língua e não tem nada a ver com um recorte. Uma língua entendida pancronicamente é uma abstração ainda maior que a mencionada 
acima e, não raro, se fundamenta apenas em razões extralinguísticas (sobretudo políticoideológicas).

Resumindo, para entendermos como uma língua funciona é preciso mesclar dados históricos com os elementos presentes da comunicação atual entre os falantes. Sob a ótica da Morfologia, caberia fazer as seguintes observações sobre a consciência do falante atual a respeito do reconhecimento de uma terminação qualquer como um sufixo:

- Da perspectiva do falante, o reconhecimento de um sufixo só pode ocorrer de forma consciente quando a terminação é ainda produtiva e expressiva. Esta perspectiva tende a ser simulada nas metodologias modernas (cf. Aronoff 1976). O falante herda a maioria das palavras que usa. Portanto, não as reinventa nem gera novas a não ser muito esporadicamente em contextos muito restritos (sobretudo na gíria e no jargão técnico). 0 bloqueio, nesse sentido, nada mais é que um elemento moral que barra eventuais neologismos sob uma ótica de cunho normativo, sobretudo durante a aquisição da linguagem. Se há universalidade no bloqueio como instrumento cognitivo ou se se restringe a línguas flexivas com tradição escrita, é algo a ser investigado;

- Sufixos com mesmo étimo, que apresentem com significantes distintos, não são reconhecíveis como iguais pelos falantes atuais, que desconhecem sua história, como é o exemplo do par sufixal -eiro e -ário. Contudo, metodologicamente, numa Morfologia preocupada não com a comunicação, mas com o fenômeno linguístico como um todo, pode-se definir que ambos são derivações fonéticas diretas ou indiretas das formas e dos valores semânticos do sufixo latino -arius.

- Sem o critério acima, os falantes atuais normalmente não podem afirmar com segurança se os sufixos de palavras como pedreiro, chiqueiro, terceiro, primeiro, janeiro pertencem ou não ao mesmo grupo semântico de sapateiro e de galinheiro, apesar de ser possível reunirmos todos direta ou remotamente sob o mesmo étimo (ou seja, -arius). Também, sem se levar em conta critérios de produtividade norteadores (que são úteis para 
entender a língua como comunicação e não como conjunto de formas), não é possível afirmar ou negar se macaxeira e inteiro, que estão vinculados a outros étimos, também pertencem ao grupo ou se são coincidências formais;

- Muitas vezes, a despeito de se detectar um significado para o radical e outro para o sufixo, o falante pode confundir-se perante o significado mais corrente da palavra como um todo e não enxergar o significado composicional no momento da criação do item lexical para a criação de paráfrases adequadas. Isso requereria investigação em sincronias pretéritas e ocorre, como já dissemos, por exemplo, com a palavra chuveiro (Viaro 2010b);

- A presença de convergências formais pode evidenciar-se não só na existência de homonímias sufixais que se tornaram produtivas (como no caso do -arium latino, que agregou a si valores do -árion grego, vide capítulo 5), mas também por meio do complexo fenômeno da criação de novos sufixos, como veremos a seguir.

Apesar de originalmente, vários sufixos do português serem de origem latina, grega ou francesa, nem todo sufixo conduz de forma evidente a um étimo num outro sistema linguístico. É possível que, quando isso ocorre, a Morfologia Diacrônica possa encontrar algumas respostas a seus problemas mais complexos à luz da Estilística. Entre o final do século XIX e o início do século XX, avanços do método etimológico ganharam terreno não só com a relativização do programa neogramático, iniciada por Schuchardt, mas também com a força teórica nos estudos da Dialetologia. Étimos foram encarados sob aspectos estilísticos e antropológicos (vide, por exemplo, publicações como a revista Wörter und Sachen produzida nesse período). A Primeira Guerra Mundial e o programa estruturalista, somados com uma banalização da crítica ao movimento neogramático, comprometeu a cientificidade dos estudos estilísticos e etimológicos, ao longo do tempo, dando azo a questionamentos feitos pelos estruturalistas do pós-guerra. O resultado disso foi a estagnação involuntária desses estudos, que foram excluídos da teorização exsurgente. Retomados parcialmente somente no final do século $X X$, quando alguns pressupostos 
estruturalistas e gerativistas foram entendidos como dogmáticos pelos funcionalistas, algumas teses pré-saussurianas abandonadas voltaram a ser apresentados à luz dos estudos da Psicologia. Retomando o célebre teste de Köhler, de 1929, um dos aspectos dogmáticos mais complexos, a questão da arbitrariedade do signo, foi questionada perante classes inteiras de palavras, como é o caso das palavras-mímicas da língua japonesa, inexistentes nas línguas ocidentais e, não raro, de difícil tradução (sobretudo o grupo chamado pela gramática japonesa de gitaigo ou gijōgo "fenômimos" ou "psicômimos") $)^{8}$. Isso nos retomaria à abandonada discussão do simbolismo sonoro com um instrumental teórico do século XX e XXI.

A associação de sons a significados rompe a dicotomia saussuriana e é muito anterior ao movimento literário do Simbolismo. Antes do poeta Rimbaud, vários autores já se debruçaram sobre o tema da não-arbitrariedade do signo, entre eles Jacob Grimm (1822) e, antes ainda, Gébelin (1776) e Leibniz (1701-1704), que retomam a tese platônica presente no Crátilo. Dela deriva-se também o fascínio pelas onomatopeias que esteve, após Herder, em inúmeras propostas de origem das línguas, assunto que chegou a ser proibido pela Société de Linguistique de Paris em 1866.

Os estudos de estilística e vários linguistas antigos, como Jespersen (1922) não aceitavam plenamente a questão da arbitrariedade do signo e a situação se manteve assim até o surgimento dos pós-bloomfieldianos e do Círculo de Praga, que, aparentemente encerraram o assunto, somente retomado hoje pela Estilística, de forma pouco organizada teoricamente.

Os psicômimos não formam uma classe em português, como no japonês, contudo, um bom exemplo é a palavra lengalenga. Encontrada já em um texto de 1759 (Infermidades da lingua e a arte que a ensina a emmudecer para melhorar, de Sylvestre Silverio da Silveira e Silva), costuma-se afirmar que se trata de "vocábulo expressivo" nos dicionários etimológicos. A semelhança entre o significado dessa palavra e o de arenga pode estabelecer, contudo, relações pouco claras, no que concerne à sua origem. Pode-se

\footnotetext{
${ }^{8}$ Somente paara o conceito "rindo", o japonês diz kuzukuzu para uma risadinha infantil, geragera para uma gargalhada, nikoniko para um sorriso, niyaniya para um sorrir aparvalhado, nitanita para um riso afetada. Centenas de outras palavras repetitivas também existem para situações sinestésicas que envolvam tato (ou outra sensação subjetiva) e/ou som e/ou sensações visuais.
} 
supor que lengalenga vem da reduplicação (do espanhol lengua? de arenga?) ou de mudanças fônicas irregulares (*longa-arenga, com mimetismo vocálico promovido pela assimilação do $o>e$ e do $r>$ I). 0 resultado, contudo, é que tanto a antiga arenga quanto a mais recente lengalenga criam, voluntariamente ou não, uma intersecção formal (-enga). Paralelamente a isso, também há uma intersecção de significado como "discurso proferido em público" e "fastídio". O falante atual que percebe, conscientemente ou não, que ambas têm significante e significado comuns, atribuirá significado a -enga (veja definições 10 a 13, no capítulo 1). Tanto a percepção quanto a racionalização do fenômeno podem, porém, conduzir a outra interpretação: de que se trata apenas de uma coincidência. Algo semelhante parece acontecer com songamonga. É sabido que o termo signo foi usado de maneira muito específica em Linguística, uma vez que o que convencionalmente se chama signo linguístico, na verdade, é um símbolo à luz dos estudos semióticos. O caso dos psicômimos, expressos não raramente de forma descontínua, remete-nos a um significado simbólico pré-sígnico, tal como vemos nas onomatopeias. É, portanto, um significado, como o de qualquer signo semiótico nãolinguístico. As onomatopeias parecem estar num nível ainda mais básico, uma vez que alguns sons presentes em uma determinada língua sequer participam de seu inventário de fonemas (é comum, por exemplo, o uso de cliques em algumas onomatopeias portuguesas representando desacordo ou negação).

O que nos interessa é que desse significado "amorfo", como diria a glossemática hjelmsleviana, se depreendem, muitas vezes signos reais, como vemos no caso de formações com um sufixo $-\mathrm{V} n g o$ (sendo $V$ uma vogal qualquer). Dito de outra forma, a origem dos sufixos e de seus significados pode estar não só em outros sufixos de sincronias pretéritas (da própria língua investigada ou de outros sistemas, com ou sem falsas segmentações), mas também podem exsurgir aparentemente ex nihilo. O que entra aqui de fato é o fenômeno da expressividade, mensurável à luz das frequências de uso e da história da língua. Nosso pressuposto é que, se dispuséssemos de descrições idealmente exaustivas das sincronias pretéritas (o que não é possível) teríamos como flagrar esse fenômeno mesmo nos sufixos mais produtivos. Desse modo, dada a 
impossibilidade de indução, apenas a dedução pode dar-nos indícios para uma teorização da etimologia dos sufixos pouco produtivos e muito expressivos, como os em -Vngo(a)(s).

Como ponto de partida, valer-nos-emos dos verbetes constantes no dicionário Houaiss (2001) e suas frequências de uso, obtidas automaticamente por meio de busca no site Google em 15/8/2006, restrita a cerca de 500 milhões de páginas em português. As palavras foram classificadas em: raríssimas (R: 1-10 ocorrências), incomuns (I: 11-200 ocorrências), comuns (C: 201-20000 ocorrências), frequentes (F: acima de 20001 ocorrências). Além disso, na tabela abaixo, referente a 982 verbetes terminados em $n g o(a)(s)$, separaram-se os com nenhuma ocorrência (Z: zero) e os verbetes excluídos da pesquisa (E) sobre a frequência, a saber, os verbetes que explicam as próprias terminações, homônimos e palavras compostas (ao todo 213), uma vez que o significado só entrará em uma análise posterior. Dessa forma, apenas 769 palavras serão analisadas na porcentagem que se segue:

\begin{tabular}{|c|c|c|c|c|c|c|c|c|c|}
\hline \multicolumn{2}{|c|}{$\mathrm{NGO}(\mathrm{A})(\mathrm{S})$} & $E$ & Z & $\mathrm{R}$ & I & C & $\mathrm{F}$ & Total & Porcentual \\
\hline \multirow{2}{*}{$a$} & ango(s) & 16 & 3 & 6 & 13 & 20 & 15 & 57 & $7,4 \%$ \\
\hline & anga(s) & 65 & 24 & 39 & 57 & 41 & 28 & 189 & $24,6 \%$ \\
\hline \multirow{2}{*}{ e } & engo(s) & 8 & 2 & 5 & 12 & 14 & 11 & 44 & $5,7 \%$ \\
\hline & enga(s) & 8 & 5 & 7 & 9 & 11 & 10 & 42 & $5,5 \%$ \\
\hline \multirow{2}{*}{$\mathrm{i}$} & ingo(s) & 8 & 4 & 6 & 8 & 6 & 9 & 33 & $4,3 \%$ \\
\hline & inga(s) & 47 & 18 & 41 & 42 & 42 & 25 & 168 & $21,8 \%$ \\
\hline \multirow{2}{*}{0} & ongo(s) & 29 & 9 & 7 & 26 & 27 & 14 & 83 & $10,8 \%$ \\
\hline & onga(s) & 15 & 3 & 14 & 12 & 16 & 15 & 60 & $7,8 \%$ \\
\hline \multirow{2}{*}{$\mathrm{u}$} & ungo(s) & 5 & 4 & 6 & 15 & 20 & 2 & 47 & $6,1 \%$ \\
\hline & unga(s) & 12 & 2 & 9 & 13 & 14 & 8 & 46 & $6,0 \%$ \\
\hline \multicolumn{2}{|c|}{ Total } & 213 & 74 & 140 & 207 & 211 & 137 & 769 & $100 \%$ \\
\hline \multicolumn{3}{|c|}{ Porcentual } & $9,6 \%$ & $18,2 \%$ & $26,9 \%$ & $27,4 \%$ & $17,8 \%$ & $100 \%$ & \\
\hline
\end{tabular}


Levando em conta o fator tempo e o fator frequência de uso nas 769 palavras acima, chega-se à seguinte tabela para qualquer formação em -Vngo(a)(s):

\begin{tabular}{|c|c|c|c|c|c|c|c|}
\hline NGO(A)(S) & Z & R & I & C & F & Total & Porcentual \\
\hline aXIII & 0 & 0 & 1 & 3 & 2 & 6 & $0,7 \%$ \\
\hline XIII & 0 & 0 & 0 & 1 & 4 & 5 & $0,6 \%$ \\
\hline XIV & 0 & 0 & 1 & 2 & 4 & 7 & $0,9 \%$ \\
\hline XV & 0 & 0 & 0 & 6 & 5 & 11 & $1,4 \%$ \\
\hline XVI & 0 & 9 & 5 & 12 & 14 & 40 & $5,2 \%$ \\
\hline XVII & 0 & 1 & 6 & 9 & 9 & 25 & $3,2 \%$ \\
\hline XVIII & 0 & 2 & 4 & 10 & 11 & 27 & $3,5 \%$ \\
\hline XIX & 7 & 9 & 53 & 49 & 47 & 165 & $21,4 \%$ \\
\hline XX & 7 & 16 & 17 & 25 & 12 & 77 & $10,0 \%$ \\
\hline s/dat & 60 & 103 & 120 & 94 & 29 & 406 & $52,7 \%$ \\
\hline Total & 74 & 140 & 207 & 211 & 137 & 769 & $100 \%$ \\
\hline Porcentual & $9,6 \%$ & $18,2 \%$ & $26,9 \%$ & $27,4 \%$ & $17,8 \%$ & $100 \%$ & \multirow{2}{*}{} \\
\cline { 1 - 4 } & & & & & &
\end{tabular}

Levanto em conta a vogal imediatamente anterior à sequência -ngo(a)(s) e a consoante que a antecede teríamos a tabela seguinte. Observe que o símbolo para limite silábico, a saber \$ (conforme Chomsky \& Halle, 1968) aqui também pode ser interpretado como um limite vocabular (ou seja, como \#):

\begin{tabular}{|c|c|c|c|c|c|c|c|}
\hline NGO(A)(S) & $-\mathrm{a}-$ & $-\mathrm{e}-$ & $-\mathrm{i}-$ & $-\mathrm{o}-$ & $-\mathrm{u}-$ & Total & Percentual \\
\hline$-\$ \mathrm{p}-$ & 8 & 1 & 7 & 18 & 7 & 41 & $5,3 \%$ \\
\hline$-\$ \mathrm{~b}-$ & 10 & 1 & 3 & 5 & 7 & 26 & $3,3 \%$ \\
\hline$-\$ \mathrm{~m}-$ & 12 & 6 & 10 & 7 & 2 & 37 & $4,8 \%$ \\
\hline$-\$ \mathrm{t}-$ & 29 & 3 & 100 & 10 & 11 & 153 & $19,8 \%$ \\
\hline$-\$ \mathrm{~d}-$ & 9 & 8 & 11 & 13 & 6 & 47 & $6,1 \%$ \\
\hline
\end{tabular}




\begin{tabular}{|c|c|c|c|c|c|c|c|c|}
\hline \multicolumn{2}{|c|}{$-\$ n-$} & 5 & 0 & 10 & 2 & 7 & 24 & $3,1 \%$ \\
\hline \multicolumn{2}{|c|}{$-\$ k-$} & 29 & 2 & 0 & 12 & 11 & 54 & $7,0 \%$ \\
\hline \multicolumn{2}{|c|}{$-\$ g-$} & 20 & 5 & 1 & 6 & 2 & 34 & $4,4 \%$ \\
\hline \multicolumn{2}{|c|}{$-\$ \mathrm{n} n-$} & 6 & 1 & 1 & 0 & 0 & 8 & $1,0 \%$ \\
\hline \multicolumn{2}{|c|}{$-\$ f-$} & 2 & 0 & 1 & 0 & 4 & 7 & $0,9 \%$ \\
\hline \multicolumn{2}{|c|}{$-\$ v-$} & 0 & 1 & 1 & 1 & 1 & 4 & $0,5 \%$ \\
\hline \multicolumn{2}{|c|}{$-\$ s-$} & 14 & 2 & 2 & 4 & 4 & 26 & $3,3 \%$ \\
\hline \multicolumn{2}{|c|}{$-\$ z-$} & 9 & 1 & 5 & 1 & 2 & 18 & $2,3 \%$ \\
\hline \multicolumn{2}{|c|}{$-\$ \int-$} & 5 & 0 & 9 & 1 & 3 & 18 & $2,3 \%$ \\
\hline \multicolumn{2}{|c|}{$-\$ 3-$} & 2 & 0 & 5 & 2 & 1 & 10 & $1,3 \%$ \\
\hline \multirow{2}{*}{$-\Gamma-$} & $-V \$ r-$ & 51 & 15 & 11 & 20 & 11 & 108 & $14,0 \%$ \\
\hline & $-\$ C r-$ & 4 & 2 & 2 & 5 & 2 & 15 & $1,9 \%$ \\
\hline \multicolumn{2}{|c|}{$-\$ x-$} & 2 & 5 & 0 & 1 & 0 & 8 & $1,0 \%$ \\
\hline \multirow{2}{*}{$-1-$} & -V\$I- & 6 & 23 & 16 & 26 & 11 & 82 & $10,6 \%$ \\
\hline & $-\$ \mathrm{Cl}-$ & 0 & 0 & 0 & 2 & 0 & 2 & $0,2 \%$ \\
\hline \multicolumn{2}{|c|}{$-\$ \Lambda-$} & 1 & 0 & 0 & 0 & 0 & 1 & $0,1 \%$ \\
\hline \multicolumn{2}{|c|}{$-i-$} & 9 & 0 & 0 & 6 & 1 & 16 & $2,0 \%$ \\
\hline \multicolumn{2}{|c|}{$-u-$} & 10 & 2 & 2 & 1 & 0 & 15 & $1,9 \%$ \\
\hline \multicolumn{2}{|c|}{-a- } & 1 & 1 & 1 & 0 & 0 & 3 & $0,3 \%$ \\
\hline \multicolumn{2}{|c|}{-e- } & 0 & 2 & 0 & 0 & 0 & 2 & $0,2 \%$ \\
\hline \multicolumn{2}{|c|}{$-0-$} & 1 & 3 & 0 & 0 & 0 & 4 & $0,5 \%$ \\
\hline \multicolumn{2}{|c|}{ \#- } & 1 & 2 & 3 & 0 & 0 & 6 & $0,7 \%$ \\
\hline \multicolumn{2}{|c|}{ Total } & 246 & 86 & 201 & 143 & 93 & 769 & $100 \%$ \\
\hline \multicolumn{2}{|c|}{ Percentual } & $31,9 \%$ & $11,1 \%$ & $26,1 \%$ & $19,0 \%$ & $12,0 \%$ & $100 \%$ & \\
\hline
\end{tabular}

Do ponto de vista neológico, de fato, a sequência sonora parece apontar para algum valor depreciativo como veremos abaixo. No entanto, para -Vngo ser sentido como sufixo, 
foi preciso haver antecedentes em que se apoiasse a produtividade, o qual parece repousar sobretudo nas formas em -engo(a)(s).

A terminação -engo $(a)(s)$ cedo adquire valor de sufixo relacional no português e este deve ser considerado o seu valor original (como ocorreu com o -arius latino). Normalmente atribui-se uma origem germânica ${ }^{9}$. O termo avoengo "que procede dos avós" se antevê num documento latino do século X (922 per quos auemus illa de auolinga siue et de parentela, Dipl., doc. № 26, p.17). No século XI documenta-se também regalengo "pertencente ao rei (mais especificamente um terreno)" (1077 quia ille dux tenuit regalengo et condadu Dipl., p.334; realengo aparece só no século XV). Do século XII é a palavra abadengo "(bens) pertencente(s) ao abade" (1116, cf. RL). Do séc XIV a palavra judengo "relativo aos judeus" e solarengo "relativo ao solar" (ambas conforme FichIVPM ver CD Casa Rui Barbosa).

Desse modo -engo parece ter um sentido fixo, presente também em outras línguas ibero-românicas. Pharies $(1990,2002)$ mostra que as cerca de 50 palavras castelhanas em -enco (metade do navarro-aragonês) e as muitas outras formadas em -engo se afiliariam ao sufixo patronímico gótico -ingôs (que teria formado vários topônimos no italiano), via provençal e catalão. Um resquício do patronímico se encontra em Alvarenga "filho de Álvaro". Algumas palavras acima listadas também aparecem nessas línguas: cast abadengo (Séc. XI: 1099), cat abadenc (Séc. XI: 1068); cast realengo (Séc. XIII), cat realench (Séc XIV: 1381); cast abolengo (Séc. XIII: 1223); cast solariengo (Séc. XI: 1099, hoje solariego); prov montanhenc.

Formas deadjetivais se veem também em cores, como verdoengo, do século XV (FichIVPM, mas a forma verdolengo não tem datação no Houaiss). Aparentemente, o engo nesse caso tem um valor derivado do diminutivo (melhor dizendo, a atenuação de cores expressa-se atualmente pelo circunfixo a...ado), ao qual se associou alguma pejoratividade ao significado lexical apenas muito mais tarde. Paralelos com bases que

\footnotetext{
${ }^{9}$ As datações doravante são retiradas do dicionário de Houaiss \& Villar (2001), complementadas ou retroagidas em Machado $\left(1967^{2}\right)$, Cunha $\left(1989^{3}, 2006\right)$ e dicionários de gírias citados na bibliografia final, bem como de pesquisas feitas em www.fflch.usp.br/dlcv/neo/ (e banco de dados ainda inédito de leda Maria Alves - USP), www.corpusdoportugues.org e http://books.google.com
} 
designam cores se veem claramente nas palavras catalãs (e occitanas) negrenc "meio negro", rogenc "avermelhado" e blavenc "azulado". O occitano também tem vermelhenc "avermelhado", que passou ao nordeste espanhol sob a forma bermejenco e a palavra azulenco "azulado" é considerada tardia no espanhol, o que revela a produtividade específica. Outras palavras nas línguas ibero-românicas apontam para a transição do valor adjetivo para o pejorativo por meio de formas diminutivas (por exemplo, leonês malenco "enfermiço", asturiano caminencu "que se cansa facilmente ao caminhar") e a produtividade ainda se vê fora da Europa (panamenho fulenco "meio ruivo"). O interfixo ol- em verdolengo pode ter sua origem num sufixo diminutivo de origem latina -olum, como ocorre com -eg-em pedr-eg-ulho, supostamente do latim -ic-. Como no caso de eiro, o sufixo também associou-se inicialmente a deficiências físicas (cegu-eira) e depois a insuficiências morais e comportamentais, que geram a pejoratividade (bob-eira): espanhol centro-americano flaquenco "fraquinho", mexicano mudenco "mudo" e guatemalteco patulenco "manco" (de pata) pelenco "cavalo velho e arruinado" (de pelo). No português alentejano encontra-se malazengo "adoentado" (com interfixo-az-, 1920: Aniceto Reis Gonçalves Viana - Vocabulário ortográfico e remissivo da língua portuguesa). Também pelharengo "magro" (1943 - Pequeno vocabulário ortográfico da língua portuguesa) possui um interfixo -ar- (associado a outras palavras como pelanca, pelanga, pelhanca, pelharanca).

Em 1570, o Dictionarium lusitanicolatinum et vice versa de Jerônimo Cardoso abona bordalengo como crassus impolitus. O étimo é associado à cidade de Bordéus, em latim Burdigala (mas não há nenhuma datação para a variante bordelengo). Há, contudo, a palavra bordalo "bagre" que, se não atuou analogicamente, pode ser a base da palavra. O que fica bem claro, contudo, é que já no português quinhentista, o sufixo -engo já possui um valor pejorativo. O termo mulherengo também aparece na mesma obra ( $\mathrm{e}$ também na edição de 1694, com o significado mulierosus, que é o uso atual brasileiro e no espanhol mujeriego, em contraste com o lusitano que já aparece também no século XVIII, 1750 Bento Pereira Prosodia in vocabularium bilingue effoeminatus) 
No mesmo século encontramos andarengo (1566) "andarilho, errante", um deverbal (com interfixo -ar-), donde surgiriam outros, no século XIX, sobretudo na variante lusitana: divertenga "divertimento" (a1894) e entretenga "entretenimento" (1899). O mesmo interfixo -ar-surge em pilharengo "que tem o hábito de pilhar" (1882 na Brasileira de Prazins, de Camilo Castelo Branco). O caráter coloquial do sufixo se torna cada vez mais evidente, apesar da baixa produtividade. No português brasileiro, a pejoratividade se deu sobretudo em bases nominais, como em majorengo "delegado de polícia" (do espanhol argentino mayorengo, abonado em português já em 1922: Raul Pederneiras - Geringonça carioca; com o sentido de "autoridade superior" em 1902: Alexandre José de Mello Moraes - Factos e memorias). No entanto, também encontramos um deverbal em pendenga (1889 Henrique de Visconde Beaurepaire-Rohan - Diccionario de vocabulos brasileiros)

Também se atesta no século XIX o gentílico vigilengo, utilizado como variante de "vigilense" (habitante da cidade de Vigia, no Pará). Referências à canoa vigilenga se abonam em 1899. Outro gentílico faz referência ao gado mertolengo (1872:365 de Mértola, $O$ archivo rural, vol, 14). Ainda se encontra produtivo o -engo deadjetival e adjetivador, como se vê em liberalengo (1871 Júlio Dinis: Os fidalgos da casa mourisca) "relativo ao partido liberal".

Empréstimos também reforçam alguns padrões. O sufixo -engo adjetivador ainda é produtivo no século XX, como provam invernengo (1920 Aniceto Reis Gonçalves Viana Vocábulo ortográfico e remissivo da língua portuguesa, proveniente do italiano, invernengo "(trigo/linho) que amadurece no inverno" 1789, também presente no provençal ivernenc); principengo (1921 Fialho d'Almeida - Estancias d'arte e de saüdade). Além dessas, no verbete -engo, o Houaiss cita as palavras bicharengo ("texugo" com interfixo -ar-, 1906: Aniceto Reis Gonçalves Viana - Apostilas aos dicionários portugueses, também no espanhol venezuelano "objeto estranho, inútil" "pênis" e no feminino bicharenga "vulva"). Sentidos pejorativos abundam a partir do século 18, como em molenga (século XIX: 1878; cf. 1900:196 Érico Veríssimo: noite) e monstrengo (1817:471 Correio Braziliense ou armazém literário, vol. 18; a forma desnasalada mostrengo já no 
século XVIII: 1752:267 Vida do veneravel padre Belchior de Pontes). Nos Anais da Câmara dos deputados (1878:46) aparece a forma melenga ("ha 40 e tantos annos que vivo nesta melenga"), supostamente vindo de mel. Também se registra a palavra torengo "indivíduo de baixa estatura", que viria de tora.

Há diversas palavras expressivas em -engo(a)(s) que não permitem a depreensão de um sufixo. Segundo o dicionário Houaiss, até o século XIV, além das palavras já citadas (e de outras não mais usadas), ainda hoje sobrevive a palavra podengo "raça de cães" (sentido figurado: "humilde, bajulador"). Do século XV temos arenga, camarlengo (ou camerlengo) "cardeal que substitui o papa entre a morte do anterior e a eleição do sucessor", flamengo, framengo, rengo. Do século XVI sengo. Do século XVII engos. Do século XVIII alenga. Do século XIX abanheenga, alvarenga, capenga, lengalenga, mamulengo, maturrengo, parlenga, perlenga, quenga, quengo, relengo, renga, resmelengo, senga. Do século XX bengo, camalenga, cambalenga. Outras 38 (44,2\%) não têm datação.

As palavras em -engo(a)(s) frequentes e comuns do dicionário Houaiss em ordem de frequência são 46 (53,5\%):

flamengo, alvarenga, realengo, mengo, flamenga, dengo, lengalenga, capenga, mulherengo, mamulengo, enga, reguengo, bengo, pendenga, menga, monstrengo, solarengo, arenga, mostrengo, quenga, molenga, podengo, renga, camerlengo, molengo, estrovenga, abadengo, senga, avoenga, framengo, denga, sengo, verdolengo, engos, bangalafumenga, quengo, avoengo, rengo, catenga, andarengo, camarlengo, perlenga, abanheenga, vigilenga, verdoengo, entretenga

É sensível a presença de termos tupis e bantus nas várias camadas do léxico, sobretudo a partir do século XVIII. A exoticidade dessas palavras poderia ter colaborado para reforçar o traço pejorativo e esse molde fônico novo se espraiará para várias formações do tipo $-\mathrm{V} n g o(a)(s)$, como se verá. A ausência de étimos confiáveis para as palavras supostamente africanas permite que as tratemos, em parte, como possíveis formações expressivas. A associação cada vez mais notável de tais palavras ao registro coloquial, desde o século XVI, intensifica a tendência à pejoratividade, bem como há um relaxamento da vogal final (há formas como molenga, molengo e molengue). Outras formas em -engue aparecem também no espanhol: perrengue "menino que facilmente se 
irrita" (1640) viria de perro; perendengue "penduricalho" (1611) viria de pender, com suposta infixação anômala de -er-, gerada por meio de metátese ${ }^{*}$ pend-er-engue > perend-engue).

Às vezes, há confusão entre sufixos, que é indício de convergência formal (parlenda, 1899 parlenga ou 1890 perlenga "falatório" "discussão acalorada").

A pejoração se observa em uma gama variada de assunto, às vezes como sentido secundário, mas várias vezes no sentido básico da palavra:

- Locais precários: a1958 bengo "lugar mal frequentado" "estabelecimento comercial muito modesto", mandengo, mandembe ou séc. XX mambembe "lugar de mato cerrado, de difícil acesso";

- Imperfeições físicas ou morais: 1899 rengo "coxo" "doença nos quartos traseiros dos cavalos", 1899 resmelengo ou resmelengue "rabugento" "avarento", bangalafumenga "indivíduo insignificante e inútil", 1899 capenga "coxo, manco" "defeituoso"; maenga "joão-ninguém"; podengo "bajulador, humilde";

- Certas profissões que envolvem violência ou sexo: maenga "polícia militar ou civil" "joão-ninguém", quenga "prostituta";

- Apreciação negativa de ações: tengo-tengo "lentamente", quenga "“coisa inútil”; estrovenga "coisa complicada ou esquisita" 1836; lengalenga "conversa enfadonha" "narrativa demorada e fastidiosa" 1858

- Sexo: estrovenga "pênis".

A pejoração advém, muitas vezes do significado da palavra e não do sufixo: séc. XV realengo "próprio do rei", "sem dono", "sem ordem"; séc. XX monstrengo ou 1634 mostrengo "ser monstruoso" "indivíduo muito feio" "indivíduo desajeitado" "coisa disforme ou descomunal" "coisa malfeita ou de péssimo gosto" "coisa inútil" "coisa absurda"; 1525 sengo "prudente" "fingido"; 1452 arenga "discurso em público" "discurso cansativo" "disputa" "intriga, mexerico" "trabalho enfadonho". 
Paradoxalmente, algumas palavras parecem ter uma valoração positiva: torunguenga ou tourunguenga "pessoa destemida e respeitada". Igualmente de 1899 quengo "conteúdo do coco" nasce o sentido de "cabeça" "indivíduo inteligente, espertalhão"; perrengo ou 1836 perrengue "covarde" "lerdo, desalentado" "teimoso, birrento" "cavalo manco" "bate-boca" "situação complicada". A palavra serenga não tem etimologia. Segundo o dicionário Houaiss, trata-se de um "canto sem palavras de remeiros em procissão fluvial" na festa do Divino. Surge uma dúvida se a base semântica com lengalenga seria pura coincidência.

Levando-se em conta a consoante imediatamente anterior ao sufixo, dos 86 verbetes com terminação -engo(a)(s) constantes no dicionário Houaiss observa-se uma grande propensão à anterioridade de uma líquida ( $r$ ou l):

\begin{tabular}{|c|c|c|c|c|c|}
\hline \multicolumn{2}{|c|}{ ENGO(A)(S) } & $-\mathrm{O}(\mathrm{s})$ & $-a(s)$ & Total & Porcentual \\
\hline \multirow{5}{*}{ Labiais } & $p$ & 0 & 1 & 1 & $1,1 \%$ \\
\hline & $b$ & 1 & 0 & 1 & $1,1 \%$ \\
\hline & $\mathrm{m}$ & 3 & 3 & 6 & $6,9 \%$ \\
\hline & $f$ & 0 & 0 & 0 & $0,0 \%$ \\
\hline & $\mathrm{v}$ & 0 & 1 & 1 & $1,1 \%$ \\
\hline \multirow{7}{*}{$\begin{array}{l}\text { Dentais e } \\
\text { alveolares }\end{array}$} & $\mathrm{t}$ & 0 & 3 & 3 & $3,4 \%$ \\
\hline & $d$ & 5 & 3 & 8 & $9,3 \%$ \\
\hline & $\mathrm{n}$ & 0 & 0 & 0 & $0,9 \%$ \\
\hline & $\mathrm{s}$ & 1 & 1 & 2 & $2,3 \%$ \\
\hline & $z$ & 1 & 0 & 1 & $1,1 \%$ \\
\hline & I & 8 & 9 & 17 & $19,7 \%$ \\
\hline & 1 & 14 & 9 & 23 & $26,7 \%$ \\
\hline \multirow{3}{*}{$\begin{array}{c}\text { Palatais e } \\
\text { velares }\end{array}$} & $\mathrm{k}$ & 1 & 1 & 2 & $2,3 \%$ \\
\hline & $\mathrm{g}$ & 1 & 4 & 5 & $5,8 \%$ \\
\hline & $\mathrm{n}$ & 1 & 0 & 1 & $1,1 \%$ \\
\hline
\end{tabular}




\begin{tabular}{|c|c|c|c|c|c|}
\hline & $\int$ & 0 & 0 & 0 & $0,0 \%$ \\
\hline & 3 & 0 & 0 & 0 & $0,0 \%$ \\
\hline & $x$ & 4 & 1 & 5 & $5,8 \%$ \\
\hline & $\kappa$ & 0 & 0 & 0 & $0,0 \%$ \\
\hline \multirow{5}{*}{ Vogais } & $\mathrm{e}$ & 0 & 2 & 2 & $2,3 \%$ \\
\hline & $\mathrm{i}$ & 0 & 0 & 0 & $0,0 \%$ \\
\hline & $a$ & 0 & 1 & 1 & $1,1 \%$ \\
\hline & 0 & 2 & 1 & 3 & $3,4 \%$ \\
\hline & $\mathrm{u}$ & 1 & 1 & 2 & $2,3 \%$ \\
\hline \multicolumn{2}{|c|}{$\#$} & 1 & 1 & 2 & $2,3 \%$ \\
\hline \multicolumn{2}{|c|}{ Total: } & 44 & 42 & 86 & $100 \%$ \\
\hline \multicolumn{2}{|c|}{ Porcentual: } & $51,1 \%$ & $49,0 \%$ & $100 \%$ & \\
\hline
\end{tabular}

De fato, podemos imaginar que -rengo(a)(s) e -lengo(a)(s) como subtipos dessa terminação. É de se observar que -engo(a)(s), nesse aspecto se aparenta com-ento(a)(s): friorento/ friolento também têm a intromissão de um interfixo -or- ou -ol- , como nos casos já citados de verdolengo. Curiosamente, há de fato no castelhano antigo a palavra friolenc "friorento" (Séc. XVI).

A partir do sufixo e da terminação sufixoide -engo(a)(s) é possível observar que formas em -ango(a)(s) e -ongo(a)(s) tiveram convergência semelhante. Apesar de nunca se ter formado um sufixo -*ungo(a)(s), o mesmo se pode dizer dessa terminação e, em certa medida, também as formas em -ingo(a)(s) entram no mesmo processo. A seguir veremos como verdadeiros sufixos nascem da extensão do significado avaliativo da base ou de toda a palavra.

Um pequeno teste foi submetido a dez pessoas conhecidas, falantes do português, de três regiões brasileiras distintas (Nordeste, Sudeste e Sul). Perante a pergunta: que significa zorongo ou sorongo?, aparentemente ninguém conseguiu responder espontaneamente de forma segura, embora alguns tivessem chegado perto dos sentidos 
dicionarizados. Duas pessoas simplesmente disseram que não sabiam e não arriscaram nenhum sentido, as outras afirmaram que associavam a palavra a:

- um tipo de dança, alteração de zarango "ciranda";

- à saída de praia, isto é, à canga (associação com canga?);

- alguém cansado, espantado, sem ação (associação com molenga?);

- alguém desqualificado, estúpido (associação explícita com mocorongo ou com songamonga);

- alguém zangado (z-, -ng-).

Esse tipo de teste, apesar de feitos mais por psicólogos do que por semanticistas, mostra que o significado de palavras expressivas nem sempre é óbvio para o falante. Em outros testes, resultados muito distintos foram obtidos com perguntas do tipo: qual a diferença entre um cretino, um crápula, um mentecapto e um energúmeno? Aparentemente, mesmo sendo conhecidas essas palavras, a associação com outras parece ser crucial na resposta.

É muito comum definir "sufixo" como uma unidade mínima significativa, portanto, um signo, que se define, necessariamente, com um significado e com um significante. Concede-se que o significante esteja ausente, de modo que se pode falar de morfemaszero, que têm significado, porém não têm um significante. O inverso é mais problemático: os interfixos, por exemplo, seriam unidades sem significado, mas com um significante e, esbarra-se, sempre que se discute sobre o conceito de interfixação a sua compatibilidade ou não com o conceito de alomorfia. Mais complexo é o signo sem significado que tem funções classificatórias, como a vogal temática, haja vista que essas classes nem sempre são totalmente artificiais, ou seja, criadas pela história da gramática. Nesse âmbito, costuma-se discutir filosoficamente o que vem a ser de fato "significado". Somente concedendo um significado especial a vogais temáticas, um modelo linguístico poderia justificar que haja vogais temáticas, por exemplo, como ocorre com a primeira pessoa do singular da primeira conjugação verbal latina e portuguesa (Câmara Jr $2005^{37}$ ). Se não se concede significado à vogal temática, chamar o locus que "deveria" ser ocupado por uma 
vogal temática inexistente é um flagrante paradoxo que revela a fragilidade das bases epistemológicas, não sustentáveis, nesse caso, por explicações ad hoc.

Mais problemática ainda se torna a questão semântica quando se aventura a depreenderem-se os elementos de composição de uma palavra. Para tal, lança-se mão com frequência de esquemas didáticos e intuitivos, que não contribuem para o entendimento do fenômeno. O problema maior que se vê nisso é que o falante nativo, arvorado na sua condição de juiz da língua que fala, parece ter conhecimento prévio do fato e reage a qualquer afirmação que fuja da intuição, por mais que tenha corroboração na variação que foge à variante dialetal que domina, quer espacial-, quer temporalmente.

No caso de admitirmos que o significado é uma associação passível de depreensão momentânea, a qual, por sua vez, pode perder força estilística e, consequentemente, fossilizar-se, num tempo de uma existência humana, nada mais interessante que entender esse mesmo fenômeno desvinculado das amarras de um falante qualquer da língua que a busca representar, uma vez que o falante nativo é um limitador extremo do fenômeno estudado. Sua opinião acerca de sua própria língua está limitada, ainda mais aquém das suas experiências pessoais, a fatores extremamente complexos do ponto de vista físico e psicológico, como o interesse, a memória, a veracidade e a consciência (Viaro 2005a). 0 julgamento do significado deve, portanto, ser supraindividual e essa é a razão pela qual nos pautaremos preponderantemente em informações de dicionários.

Dadas as palavras portuguesas terminadas em $-n g o(a)(s)$, não se pode dizer $a$ priori que estamos diante de um sufixo, como ocorre com a maioria das terminadas em eiro $(a)(s)$, por exemplo. As formações estilísticas promovidas por essa terminação, contudo, não podem ser atribuídas a algo exterior à própria linguagem que a produz. Também a vogal nasal que o precede pode afetar os valores semânticos que thes são agregados. Cumpre aqui observar que o significado, ao menos, deve ter uma subdivisão provisória:

- Significados descritivos: considera-se descritivo qualquer valor semântico equivalente quer à descrição de um ser (em jaqu-eira, o sufixo carrega em si o núcleo semântico principal da palavra e equivale a um substantivo como "árvore", que, aliás, é seu gênero ou hiperônimo), quer à descrição de uma qualidade sensível (em jaqu-inha, o sufixo não 
carrega o núcleo semântico, mas descreve um elemento imediatamente sensível, isto é, a noção de "pequeno");

- Significados classificatórios: considera-se classificatório o sufixo que, por si, remete o valor do radical para uma categoria distinta, havendo, portanto, por vezes, também a transposição do núcleo. Em esquelét-ico, a transposição categorial do radical para a palavra se dá por meio do sufixo, uma vez que equivale à solução sintagmática "do esqueleto", ora, substantivos e adjetivos são categorias distintas, não necessariamente apenas do ponto de vista gramatical (contaminado com o dogmatismo detectável pela Historiografia), mas sobretudo do ponto de vista paradigmático e sintagmático. Também teriam significados classificatórios as vogais temáticas, neste caso ou casos mais concretos, como sufixos como o de celesti-al, que não promovem nenhuma translação categorial do ponto de vista das classificações gramaticais, embora alavanque um caráter abstrato que pode ser flagrado em contextos distintos ${ }^{10}$.

- Significados avaliativos: consideram-se costumeiramente as avaliações como um terceiro tipo de significados, contudo, na verdade, transcendem os valores semânticos e poderiam ser entendidas num nível extrassemântico, o que poderia romper o binarismo estoico entre o significante e o significado. A principal característica das avaliações é a possibilidade de coexistência com outros valores (como veremos no capítulo 4). No caso acima citado, o sufixo -inho, para além do significado de "pequeno" e antes de ter completamente o significado de "bom", pode apresentar um complexo semântico, em que haja avaliação e significado descritivo ("pequeno e bom"). Cumpre então distinguir significados avaliativos como "bom" de aglutinadores avaliativos como "bom". Os aglutinadores transitam no terreno das avaliações pessoais e, portanto, à parole e, por meio do tempo, adquirem significados mais estáveis na langue corrente. Por isso, é comum ocorrer duas acepções distintas convivendo ao mesmo tempo na mesma palavra: o sufixo de pov-ão pode ser interpretado quer como "bom", quer como "de baixa qualidade" (que está mais claro em pov-inho, pov-aréu), no entanto, valores sociais aceitos podem arcaizar concepções e tabuizar palavras, de forma que a diacronia é muito mais visível nessa área (como provam as sufixações nas gírias e outras linguagens especiais). Portanto, só se pode falar de valores semânticos avaliativos com muita cautela.

No que se refere à terminação -ongo(a)(s), de formas criadas no século XV temos hoje apenas os derivados do latim longus (longo, longa, prolonga, delonga, perlonga). No XVI surigiriam palavras de origem grega (ditongo, tritongo) e surgem empréstimos de origem não-europeia (dongo, guiraponga, juiponga), tendência continuada no séc. XVII (congo, dugongo, mondonga). No século XVIII, novos latinismos ressuscitados (oblongo, prolongo) e outros supostos exotismos (araponga, candonga, mondongo, papironga, quicongo). No XIX, o mesmo movimento continua: latinismos (alonga, barbilongo,

\footnotetext{
${ }^{10}$ Com isso não afirmamos que haja sinonímia, pois também o termo "sinonímia" deve ser passível de discussão historiográfica.
} 
perlongo, pernalonga, pernilongo, quadrilongo, rabilongo, trilongo), grecismos (monotongo e o híbrido semiditongo) e supostos exotismos (cacongo, camondongo, camundongo, caponga, drongo, gaponga, gongo, jimbongo, jongo, milonga, milongo, moponga, obongo, ponga, pongo, porongo, sambongo, songamonga, tonga, tronga, uricongo, urucongo, zorongo). No século XX somente temos os exotismos (andongo, baçongo, bassongo, caiongo, conga, donga, gronga, guaçatonga, kacongo, mondrongo, muçorongo, mussorongo, muxicongo, sabiaponga). Do corpus, 76 palavras estão sem datação $(53,1 \%)$. As palavras frequentes e as comuns do dicionário Houaiss em ordem de frequência são 72 (50,3\%):

\begin{abstract}
longo, longa, congo, tonga, prolonga, valongo, camundongo, araponga, bongo, tsonga, conga, milonga, pernilongo, alonga, pernalonga, jongo, ponga, gongo, donga, caponga, ditongo, mironga, porongo, mongo, candonga, pongo, delonga, oblongo, drongo, rabilongo, morongo, dongo, gonga, mondongo, prolongo, songamonga, zorongo, uiraponga, cacongo, muriongo, riponga, tongo, xongas, rabilonga, sorongo, mondrongo, trapizonga, quicongo, dugongo, tritongo, guaçatonga, mocorongo, ronga, perlonga, mundongo, andongo, ndongo, mangonga, bacongo, caaponga, camondongo, quadrilongo, catonga, pernilonga, tronga, cangongo, milongo, zambiapongo, olongo, guiraponga, caiongo, missongo.
\end{abstract}

São 143 casos com -ongo(a)(s) no Dicionário Houaiss (ao todo, 83 verbetes com ongo e 60 verbetes com -onga ou -ongas), veem-se várias terminações semelhantes:

\begin{tabular}{|c|c|c|c|c|c|}
\hline \multicolumn{2}{|c|}{ ONGO(A)(S) } & $-0(s)$ & $-a(s)$ & Total & Porcentual \\
\hline \multirow{5}{*}{ Labiais } & $p$ & 5 & 13 & 18 & $12,5 \%$ \\
\hline & $b$ & 5 & 0 & 5 & $3,4 \%$ \\
\hline & $\mathrm{m}$ & 1 & 6 & 7 & $4,8 \%$ \\
\hline & $f$ & 0 & 0 & 0 & $0,0 \%$ \\
\hline & $v$ & 1 & 0 & 1 & $0,6 \%$ \\
\hline \multirow{4}{*}{$\begin{array}{l}\text { Dentais e } \\
\text { alveolares }\end{array}$} & $\mathrm{t}$ & 6 & 4 & 10 & $6,9 \%$ \\
\hline & $d$ & 7 & 6 & 13 & $9,0 \%$ \\
\hline & $\mathrm{n}$ & 2 & 0 & 2 & $1,3 \%$ \\
\hline & $\mathrm{s}$ & 3 & 1 & 4 & $2,7 \%$ \\
\hline
\end{tabular}




\begin{tabular}{|c|c|c|c|c|c|}
\hline & $z$ & 0 & 1 & 1 & $0,6 \%$ \\
\hline & r & 14 & 11 & 25 & $17,4 \%$ \\
\hline & 1 & 18 & 10 & 28 & $19,5 \%$ \\
\hline \multirow{7}{*}{$\begin{array}{c}\text { Palatais e } \\
\text { velares }\end{array}$} & $k$ & 10 & 2 & 12 & $8,3 \%$ \\
\hline & g & 3 & 3 & 6 & $4,1 \%$ \\
\hline & $\mathrm{n}$ & 0 & 0 & 0 & $0,0 \%$ \\
\hline & $\int$ & 0 & 1 & 1 & $0,6 \%$ \\
\hline & 3 & 2 & 0 & 2 & $1,3 \%$ \\
\hline & $x$ & 0 & 1 & 1 & $0,6 \%$ \\
\hline & $\Lambda$ & 0 & 0 & 0 & $0,0 \%$ \\
\hline \multirow{5}{*}{ Vogais } & $\mathrm{e}$ & 0 & 0 & 0 & $0,0 \%$ \\
\hline & $\mathrm{i}$ & 5 & 1 & 6 & $4,1 \%$ \\
\hline & $a$ & 0 & 0 & 0 & $0,0 \%$ \\
\hline & 0 & 0 & 0 & 0 & $0,0 \%$ \\
\hline & $\mathrm{u}$ & 1 & 0 & 0 & $0,6 \%$ \\
\hline \multicolumn{2}{|c|}{$\#$} & 0 & 0 & 0 & $0,0 \%$ \\
\hline \multicolumn{2}{|c|}{ Total: } & 83 & 60 & 143 & 100 \\
\hline \multicolumn{2}{|c|}{ Porcentual: } & $58,0 \%$ & $41,9 \%$ & $100 \%$ & \\
\hline
\end{tabular}

Não se computaram os verbetes em composição (como noitibó-rabilongo, bandade-congo e balança-rabo-de-bico-longo). Nem sempre as formas em -nga são femininas, assim como nem sempre as em -ngas estão no plural. Um estudo da neutralização de supostas vogais temáticas ou terminações pluraliformes se faz necessária, mas isso não será tratado mesta tese. Salta aos olhos a falta de ocorrências de -fongo(a)(s), nhongo(a)(s) e -lhongo(a)(s).

Analisemos mais pormenorizadamente as palavras em -rongo(a)(s): corongo, macorongo, morongo, mocorongo, mucorongo, muçorongo (ou mussorongo), porongo, quissorongo e sorongo (ou zorongo). Dessas palavras, algumas aparentemente não têm aglutinador avaliativo no seu significado lexical, como nomes de árvores (muçorongo, porongo), de 
animais (corongo, morongo), de línguas (muçorongo a1953, quissorongo) e danças (zorongo 1874).

- Locais precários: brongo "bairro distante e pouco desenvolvido", "bairro de classes menos abastadas";

- Coisas feitas precariamente: gronga (1981) "qualquer artefato malfeito"

- Imperfeições físicas ou morais: mondrongo (séc. XX) "indivíduo disforme", "indivíduo preguiçoso", "indivíduo mal-vestido", tronga (1899) "mulher muito gorda", "mulher desonesta"), mangonga "indivíduo muito alto", 1913 caiongo "envelhecido, decadente", capiongo "deprimido" "que tem defeito num dos olhos", piongo "melancólico", 1784 songamonga "pessoa sonsa e disfarçada", 1727 candonga "trapaça", pindonga "mulher que sai muito de casa", 1899 milonga "habilidade de enganar";

- Certas profissões que envolvem sexo: tronga "prostituta";

- Falta de clareza: mironga "mistério", "segredo", papironga (1789 "manobra ardilosa");

- Falta de concordância: mironga "briga";

- Nacionalidades: mondrongo "português";

- Apreciação negativa de ações: macorongo "amante que explora a concubina";

- Dinheiro: 1889 jimbongo;

- Drogas: bongo;

- Rusticidade: capicongo, cangongo, biongo, trapizonga;

- Desmazelo: 1716 mondongo, 1665 mondonga;

- Incompreensibilidade: xongas, jinongonongo;

É preciso observar que há grande número de etnônimos, danças, instrumentos, iguarias, animais, e vegetais com essas terminações. Apesar da prolificidade e frequência de formas em -longo(a)(s), inspiradas em composição latinas, essa forma pouco contribuiu para a semanticização da terminação -ongo(a)(s) e sua transformação em 
sufixo. O mesmo ocorre para a terminação -tongo(a)(s) que provêm de formas gregas inspiradas em фӨópyoৎ "som articulado" (a saber, 1536 ditongo, 1576 tritongo etc.).

É difícil decidir sobre a questão semântica original de algumas palavras para entendermos se há de fato polissemia, como preconizam os dicionários, ou uma homonímia de palavras de étimos distintos. O estudo etimológico de muitas palavras terminadas em $-\operatorname{Vngo}(a)(s)$ é muito incipiente e as associações a línguas africanas muito impressionistas (e, por vezes, evidentemente falsas).

A palavra mocorongo pode significar "mulato escuro", "palhaço de folia de reis", "indivíduo natural de Santarém (PA)", sem qualquer aglutinador pejorativo evidente, mas evidentemente a pejoração está presente quando empregado no sentido de "indivíduo roceiro, de pouca instrução e modos rústicos, caipira, tabaréu". Apesar de não dicionarizado, é comum encontrar essa palavra sendo utilizada já com o valor semântico de "bobo, tonto, tolo, atarantado", sem referência às origens rústicas. A palavra sorongo parece só ter essa acepção. De qualquer forma, a terminação de sorongo e de mocorongo não têm aparentemente nenhum étimo comum. Apenas há um elemento significante coincidente e alguma frequência de uso.

Esses fatores parecem estar entre as razões do seu alavancamento do nível significante para a criação de um significado, que passou, necessariamente, pelos aglutinadores avaliativos de mocorongo e pelo significado avaliativo de sorongo.

Além da flexibilidade semântica, há oscilação formal entre as terminações: guaparonga (nome de planta), também ocorre nas formas guapironga, guaporanga (1899) e vapuronga.

A pejoratividade ou a tabuização é refletida indiretamente nas palavras onomasiologicamente ricas, de modo que araponga "pessoa que fala muito alto" é, na verdade, uma transformação semântica da palavra e é difícil avaliar se essa palavra influenciou ou foi influenciada pelo aglutinação pejorativa da terminação -ngo(a)(s). Pode-se imaginar que sua frequência de uso em sincronias pretéritas tenha sido maior do que a de hoje em dia, pois o pássaro se encontra hoje apenas em áreas muito restritas e as características que motivaram essa acepção da palavra são conhecidas muitas vezes 
apenas indiretamente, quando são. De qualquer forma, o étimo de araponga é perfeitamente conhecido desde 1728 (tupi wyra-pónga "pássaro que soa", também sob as formas 1584 guiraponga, iraponga, uiraponga).

No caso das palavras em - ungo(a)(s), não sobreviveu nenhuma palavra com essa terminação que tenha sido criada até o século XV. Do XVI há o latinismo fungo e os exotismos tunga e zunga. Do XVII são os exotismos malungo e mungo. No XVIII não haveria, segundo a datação do Houaiss, nenhuma palavra, mas as do XIX são todas exotismos (boiçununga, cabungo, calunga, dunga, funga, grutungo, guapurunga, gunga, ingurunga, jibungo, matungo, mucungo, mulungo, oricungo, porunga, punga, rarunga, trutungo, urucungo), assim como a maioria do século $X X$, com exceção da derivação regressiva resmungo (caçununga, guaçatunga, gurunga, jindungo, minungo, vissungo, zambiampungo). 61 palavras não têm datação $(65,6 \%)$. As palavras frequentes e as comuns do dicionário Houaiss em ordem de frequência são 44 (47,3\%):

fungo, dunga, xunga, sunga, tunga, calunga, gunga, malungo, chunga, funga, mungo, resmungo, zunga, porunga, chibungo, jindungo, jungo, dandalunga, golungo, xibungo, surungo, zambiapunga, urucungo, piraçununga, pilungo, quitungo, malunga, mulungo, purungo, purunga, gungas, punga, matungo, sununga, macungo, mundrungo, quibungo, mutungo, guaçatunga, caçununga, sitatunga, vissungo, calungo, bilunga

Segundo os mesmos critérios empregados em -ongo(a)(s), a terminação -ungo(a)(s) aparece em 93 palavras do dicionário Houaiss é registrada em 47 verbetes em -ungo e outras 46 sob a forma -unga(s).

\begin{tabular}{|c|c|c|c|c|c|}
\hline \multicolumn{2}{|c|}{ UNGO(A)(S) } & $-0(s)$ & $-a(s)$ & Total & Porcentual \\
\hline \multirow{4}{*}{ Labiais } & $\mathrm{p}$ & 2 & 5 & 7 & $7,5 \%$ \\
\cline { 2 - 6 } & $\mathrm{b}$ & 6 & 1 & 7 & $7,5 \%$ \\
\cline { 2 - 6 } & $\mathrm{m}$ & 2 & 0 & 2 & $2,1 \%$ \\
\cline { 2 - 6 } & $\mathrm{f}$ & 3 & 1 & 4 & $4,3 \%$ \\
\hline Dentais e & $\mathrm{v}$ & 0 & 1 & 1 & $1,0 \%$ \\
\hline
\end{tabular}




\begin{tabular}{|c|c|c|c|c|c|}
\hline \multirow[t]{6}{*}{ alveolares } & $d$ & 2 & 4 & 6 & $6,4 \%$ \\
\hline & $n$ & 2 & 5 & 7 & $7,5 \%$ \\
\hline & $\mathrm{s}$ & 2 & 2 & 4 & $4,3 \%$ \\
\hline & $z$ & 0 & 2 & 2 & $2,1 \%$ \\
\hline & r & 5 & 8 & 13 & $13,9 \%$ \\
\hline & 1 & 6 & 5 & 11 & $11,8 \%$ \\
\hline \multirow{7}{*}{$\begin{array}{c}\text { Palatais e } \\
\text { velares }\end{array}$} & $k$ & 10 & 1 & 11 & $11,8 \%$ \\
\hline & g & 0 & 1 & 1 & $1,0 \%$ \\
\hline & $\mathrm{n}$ & 0 & 0 & 0 & $0,0 \%$ \\
\hline & $\int$ & 0 & 3 & 3 & $3,2 \%$ \\
\hline & 3 & 1 & 1 & 2 & $2,1 \%$ \\
\hline & $x$ & 0 & 0 & 0 & $0,0 \%$ \\
\hline & $\kappa$ & 0 & 0 & 0 & $0,0 \%$ \\
\hline \multirow{5}{*}{ Vogais } & e & 0 & 0 & 0 & $0,0 \%$ \\
\hline & $\mathrm{i}$ & 1 & 0 & 1 & $1,0 \%$ \\
\hline & $a$ & 0 & 0 & 0 & $0,0 \%$ \\
\hline & 0 & 0 & 0 & 0 & $0,0 \%$ \\
\hline & $\mathrm{u}$ & 0 & 0 & 0 & $0,0 \%$ \\
\hline \multicolumn{2}{|c|}{ \# } & 0 & 0 & 0 & $0,0 \%$ \\
\hline \multicolumn{2}{|c|}{ Total: } & 47 & 46 & 93 & $100 \%$ \\
\hline \multicolumn{2}{|c|}{ Porcentual: } & $50,5 \%$ & $49,5 \%$ & $100 \%$ & \\
\hline
\end{tabular}

Algumas características pejorativas estão na própria palavra ou são decorrência de mudanças semânticas correlacionadas sob a ótica de mesmos valores sociais e preconceitos de classe:

- Locais precários: zunga "hospedaria de baixa categoria, reles";

- Coisas feitas precariamente: chunga "de má qualidade, reles, sem valor"; 
- Imperfeições físicas ou morais: aricungo "indivíduo muito feio", 1891 cabungo "indivíduo sem asseio e trato" ou "pessoa a quem não se deve importância", 1881 matungo "cavalo de má qualidade, que corre pouco", mundrungo "cavalo sem serventia", pilungo "cavalo ruim, sem préstimo", 1889 punga "cavalo sem serventia" "pessoa ruim" "cavalo que chega habitualmente entre os últimos colocados", xunga "mulher ordinária", curungo "enfraquecido, caduco" "indivíduo velho e feio", jungo "louro, alourado", 1899 mulungo "homem branco";

- Certas profissões que envolvem violência: 1881 calunga "gatuno, larápio",;

- Roubo: 1958 punga "furto praticado com destreza", tunga "furto, roubo";

- Apreciação negativa de ações: cafungo "indivíduo mau, bruto, cruel";

- Pobreza: surungo "baile de gente simples"

- Dinheiro: 1899 jibungo;

- Bebidas alcoólicas: malunga, piraçununga;

- Rusticidade: 1958 gurunga, séc. XX gurungumba ou 1899 ingurunga "terreno muito acidentado, com subidas e descidas íngremes, quase intransitável", muçununga "terreno alagadiço e muito ácido, de onde escorre água nociva ao homem e aos animais";

- Religião e crendices: quibungo "homem que faz feitiços", mundrunga "prática de bruxaria";

- Sexo: bilunga "pênis infantil", chibungo ou xibungo "homossexual masculino passivo";

É muito comum a aglutinação de vários sentidos pejorativos: burundunga, 1726 burundanga, burindanga ou 1922 bruzundanga "coisa de pouca serventia ou inútil, insignificância, ninharia" "falta de ordem, confusão" "linguagem confusa, difícil de entender" "coisa malfeita" "comida mal preparada, de aspecto nojento" "garrafa de feitiçaria".

Também é importante observar que algumas características positivas podem aparecer (1688 malungo "camarada, companheiro, parceiro", 1899 dunga "excepcional, 
incomparável", d1958 gunga "manda-chuva"). Obviamente há uma vasta transição dependente do discurso empregado que oscila entre a descrição neutra e a irônica de valor positivo ou negativo em diversos temas, de modo que as palavras oscilam entre o discurso da diversão e o da ofensa. Reforçam esse grupo também alguns deverbais regressivos (1899 fungo "fungação", século XX resmungo) e interjeições (tibungo! banga!).

A mesma situação de araponga se encontra na palavra caçununga (1926), que provém do tupi kasunúnga, uma espécie de vespa. O significado de "mulher de mau gênio" ou "indivíduo que incomoda" são claramente derivados do significado da palavra, mas a terminação acabou por reforçar o sucesso conotativo.

As palavras formadas em -ango(a)(s), anteriores ao século XVI são manga, canga, fanga, frango, galanga e mango. A partir do século XVI surge a palavra grega losango e uma grande gama de termos exóticos (abango, acarapitanga, anhanga, anijuaganga, ganga, jaguapitanga, puçanga, tacipitanga, tanga). Do século XVII são bugiganga, calango, lupanga, mogiganga, mubanga, pitanga, xofrango Do século XVIII são os exotismos boipiranga, burundanga, ibipitanga, miçanga, moganga, morango, orangotango, pango, pendanga, quarango, tapanhoacanga, tapiranga, zanga. O século XIX prossegue a mesma tendência: abanga, acumatanga, araçanga, araracanga, bango, cafanga, cananga, candango, cango, capanga, capiango, carango, charanga, chimango, deranga, diangas, dranga, fandango, guaporanga, guapuranga, guarapiranga, guaricanga, jacuacanga, jango, japecanga, macaranga, maturrango, molhanga, moranga, muanga, muraçanga, murapiranga, muxuango, nariganga, parasanga, pelanga, piranga, piraputanga, presiganga, quimanga, sacanga, samango, sambango, sanga, sapiranga, tango, zaranga. No século XX citem-se acamatanga, acumutanga, ajurujubacanga, anga, aracanga, ararapiranga, banga, boganga, bruzundanga, buraçanga, cabapiranga, camatanga, camiranga, carapitanga, caraputanga, changa, condurango, cumatanga, gango, icanga, inambuanhanga, itapiranga, jurupiranga, mangas, parango, sambanga, uanga, ximango. 134 palavras não têm datação (54,5\%). As palavras frequentes e as comuns do dicionário Houaiss em ordem de frequência são 104 (42,3\%): 
frango, manga, tango, mangas, morango, tanga, pitanga, guarapiranga, sapiranga, bugiganga, fandango, guaricanga, calango, ganga, itapiranga, jango, piranga, mango, rango, sanga, losango, anga, araputanga, candango, canga, franga, moranga, poranga, zanga, sango, camutanga, baranga, ibirapitanga, ibipitanga, capanga, charanga, tangolomango, orangotango, curiango, caranga, miçanga, carango, piraputanga, chimango, pango, charango, cabanga, banga, kananga, ximango, bango, muganga, munganga, anhanga, fundango, tapiranga, changa, camiranga, fanga, cananga, sarango, catanga, bruzundanga, mogango, burundanga, pendanga, araracanga, paanga, jacuacanga, loango, cango, japecanga, muirapiranga, pirapiranga, gango, saranga, galanga, mugango, quimanga, samango, itapanhoacanga, massango, saicanga, cassanga, batanga, muanga, mungango, estanga, xofrango, matanga, guaporanga, nyanga, carapitanga, moganga, parango, sambanga, mananga, cundurango, condurango, fundanga, puçanga, presiganga, uanga, sambango

Segue-se a combinação da terminação com o som do radical imediatamente anterior:

\begin{tabular}{|c|c|c|c|c|c|}
\hline \multicolumn{2}{|c|}{ ANGO(A)(S) } & $-\mathrm{O}(\mathrm{s})$ & $-a(s)$ & Total & Porcentual \\
\hline \multirow{5}{*}{ Labiais } & $p$ & 4 & 4 & 8 & $3,2 \%$ \\
\hline & $b$ & 3 & 7 & 10 & $4,0 \%$ \\
\hline & $\mathrm{m}$ & 6 & 6 & 12 & $4,8 \%$ \\
\hline & $f$ & 0 & 2 & 2 & $0,8 \%$ \\
\hline & $\mathrm{v}$ & 0 & 0 & 0 & $0,0 \%$ \\
\hline \multirow{7}{*}{$\begin{array}{l}\text { Dentais e } \\
\text { alveolares }\end{array}$} & $\mathrm{t}$ & 2 & 27 & 29 & $11,7 \%$ \\
\hline & $d$ & 3 & 6 & 9 & $3,6 \%$ \\
\hline & $n$ & 1 & 4 & 5 & $2,0 \%$ \\
\hline & $\mathrm{s}$ & 3 & 11 & 14 & $5,6 \%$ \\
\hline & $z$ & 2 & 7 & 9 & $3,6 \%$ \\
\hline & $\Gamma$ & 11 & 44 & 55 & $22,3 \%$ \\
\hline & 1 & 1 & 5 & 6 & $2,4 \%$ \\
\hline \multirow{6}{*}{$\begin{array}{c}\text { Palatais e } \\
\text { velares }\end{array}$} & $\mathrm{k}$ & 2 & 27 & 29 & $11,7 \%$ \\
\hline & g & 5 & 15 & 20 & $8,1 \%$ \\
\hline & $\mathrm{n}$ & 0 & 6 & 6 & $2,4 \%$ \\
\hline & $\int$ & 1 & 4 & 5 & $2,0 \%$ \\
\hline & 3 & 2 & 0 & 2 & $0,8 \%$ \\
\hline & $x$ & 2 & 0 & 2 & $0,8 \%$ \\
\hline
\end{tabular}




\begin{tabular}{|c|c|c|c|c|c|}
\hline & $\kappa$ & 0 & 1 & 1 & $0,4 \%$ \\
\hline \multirow{3}{*}{ Vogais } & $\mathrm{e}$ & 0 & 0 & 0 & $0,0 \%$ \\
\cline { 2 - 7 } & $\mathrm{i}$ & 5 & 4 & 9 & $3,6 \%$ \\
\cline { 2 - 7 } & $\mathrm{a}$ & 0 & 1 & 1 & $0,4 \%$ \\
\cline { 2 - 7 } & $\mathrm{o}$ & 1 & 0 & 1 & $0,4 \%$ \\
\hline \multirow{2}{*}{$\#$} & 3 & 7 & 10 & $4,0 \%$ \\
\hline \multicolumn{2}{|r|}{ Total: } & 0 & 1 & 1 & $0,4 \%$ \\
\hline \multicolumn{2}{|r|}{ Porcentual: } & $23,2 \%$ & $76,8 \%$ & $100 \%$ & $100 \%$ \\
\hline
\end{tabular}

Do ponto de vista semântico, observa-se a seguinte classificação, vinculada aos elementos coloquiais que tais vocábulos evocam:

- Coisas feitas precariamente: biango "casa pequena e/ou humilde", banga "casebre, choupana", baranga "de baixa qualidade" "mulher feia, deselegante", 1623 bugiganga "quinquilharia", "ninharia", 1706 miçanga "coisa de pouco ou nenhum valor", 1720 pendanga ou pendenga "algo que se usa com finalidades diversas" "ocupação secundária", sanga "arroz de qualidade inferior", "produto secundário";

- Imperfeições físicas ou morais: séc. XIX sambango "que ou aquele que é fraco, que não tem forças", 1899 maturrango ou 1899 maturrengo "indivíduo que não sabe montar" "indivíduo ignorante nos trabalhos relacionados ao campo" "inexperiente, inábil no exercício de qualquer atividade", sarango ou saranga "muito crédulo, simplório, tolo", séc. XX sambanga "ingênuo, palerma", 1873 sapiranga "blefarite", 1899 cafanga "falso escrúpulo" "falha, defeito", séc. XX sambanga "penetra";

- Certas profissões que envolvem violência ou sexo: calango ou carango "soldado", 1899 samango "agente policial", 1868 capanga "guarda-costas";

- Falta de concordância: 1858 fandango "confusão barulhenta", jiquipanga "festa ruidosa", saçanga "confusão, briga, motim";

- Roubo: 1899 capiango "indivíduo que furta e rouba com astúcia e destreza"; 
- Pobreza: 1899 samango "homem preguiçoso, indolente" "indivíduo maltrapilho", d1847 piranga "pessoa pobre, reles, de pouca importância" "falta de dinheiro, pobreza";

- Dinheiro: c1930 mango, 1922 changa;

- Drogas: 1913 bango, século XVIII pango ou 1554 abango "maconha", 1969 parango "pacote de maconha";

- Bebidas alcoólicas: tiaporanga "bebedeira", mungango "aguardente", como em ganga e pitianga;

- Rusticidade: mixanga, mixuango ou 1899 muxuango "indivíduo caipira, matuto, tabaréu";

- Religião e crendices: 1914 anga "olhar maléfico, mau olhado", mixilanga "beberagem, garrafada", 1561 puçanga "beberagem, feitiço"; ; azango "desdita, infelicidade", tangolomango ou 1881 tanglomango "doença que supostamente se origina de feitiço" "má sorte", 1899 muanga "coisa feita, feitiço", 1789 zanga "feitiço" "enguiço", 1985 uanga "feitiço";

- Sexo: 1878 mango "pênis", xandanga "genitália feminina".

Em algumas delas, sem étimo, como cafumango, vários significados se aglutinam: "indivíduo sem importância, de baixa condição social", "vagabundo", "caipira, tabaréu", "cozinheiro preto". O sentido genérico de "coisa" se encontra em 1873 charanga, de comida em rango e de "pessoa" há no português lusitano o termo manga, para "grande quantidade". Uma valoração positiva se entrevê em 1913 gango "afago, meiguice", puranga "bonito", surunganga "bonito, faceiro" "valente". Em 1899 ganga "senhor" temos o étimo no quimbundo nganga "feiticeiro, mágico" (vide mananga "feiticeiro indígena", nianga "curandeiro"). O termo 1789 orangotango, de origem malaia, pode significar "indivíduo feio e desajeitado", mas supostamente é algo acrescido ao significado da palavra. Inversamente o uso de franga "mulher muito jovem" soa pejorativamente.

Nesse caso há várias formas da aglutinação do tupi -pytánga "avermelhado" (sob as formas em português -pitanga, -putanga, -patanga, -matanga, -mutanga), do tupi - 
piránga "vermelho" (sob a forma -piranga, -puranga ou -poranga), do tupi -añánga "gênio protetor" (sob a forma -anhanga), do tupi -akánga "cabeça" (sob a forma acanga).

Por fim, com relação às palavras terminadas em -ingo(a)(s) e anteriores ao século XVI são apenas as palavras domingo, dominga e restinga. No século XVI surgem: acarapitinga, ambaitinga, boicininga, caatinga, carlinga, catinga, gotingo, guiratinga, ibiratinga, ingo, jacutinga, jaguacininga, pinga, pingo, pititinga, respingo, sabiatinga, sernambitinga, urubutinga. Do século XVII: aninga, choramingas, gardingo, linga, moringa, moxingo, muxinga, suaçutinga, tabatinga, vitinga. Do século XVIII: mandinga, petinga, piracatinga, rezinga, seringa. Do século XIX: acaratinga, anavinga, aratinga, aringa, atinga, binga, bolinga, calingo, cotinga, curinga, curuatinga, eslinga, flamingo, ginga, gingo, gringo, jacaretinga, jifingo, jinga, jingo, jurupetinga, lemingo, macocalinga, mingo, pacutinga, petitinga, pirapetinga, pirapitinga, piratinga, pitinga, posinga, singa, siringa, surucucutinga, talinga, telinga, titinga, tobatinga, toringo, tulingo, turingo, vatinga, vigilinga, virtingo, zinga, zingo. Do século XX: abatinga, acaiacatinga, acarlinga, ajurucatinga, anhinga, asdingo, atangaratinga, bingo, caatininga, capitinga, caracaratinga, caratinga, cedrelinga, coringa, guaçucatinga, iritinga, muinga, tiipingo, tyipingo, ubatinga, uvatinga. 97 não têm datação (48,2\%). As palavras frequentes e as comuns do dicionário Houaiss em ordem de frequência são 82 (40,8\%):

domingo, restinga, bingo, pingo, pinga, caatinga, tabatinga, gringo, seringa, caratinga, jacutinga, flamingo, ginga, ingo, guiratinga, coringa, inga, domingas, mingo, chuinga, pirapetinga, curinga, mandinga, guaratinga, moringa, xingo, catinga, pitinga, anhinga, bracatinga, aratinga, respingo, zinga, aringa, dominga, pirapitinga, cotinga, dingo, batinga, linga, petinga, cafuringa, binga, choramingas, jinga, gingo, rezinga, jingo, zuninga, pititinga, choramingo, carlinga, siringa, jurupinga, gardingo, petitinga, biguatinga, ibiratinga, aninga, surucutinga, atinga, coatinga, capitinga, ubatinga, dinga, singa, muxinga, jacaretinga, piratinga, hinga, zingo, cedrelinga, boicininga, bolinga, tietinga, pichilinga, eslinga, caxinga, lapinga, muinga, curuatinga, muiratinga

Há 201 verbetes com terminação -ingo(a)(s), a grande maioria com a terminação tinga, de origem tupi. 


\begin{tabular}{|c|c|c|c|c|c|}
\hline \multicolumn{2}{|c|}{$\operatorname{INGO}(\mathrm{A})(\mathrm{S})$} & $-O(s)$ & $-a(s)$ & Total & Porcentual \\
\hline \multirow{5}{*}{ Labiais } & $p$ & 4 & 3 & 7 & $3,4 \%$ \\
\hline & $b$ & 1 & 2 & 3 & $1,4 \%$ \\
\hline & $\mathrm{m}$ & 6 & 4 & 10 & $4,9 \%$ \\
\hline & $f$ & 1 & 0 & 1 & $0,4 \%$ \\
\hline & $\mathrm{v}$ & 0 & 1 & 1 & $0,4 \%$ \\
\hline \multirow{7}{*}{$\begin{array}{l}\text { Dentais e } \\
\text { alveolares }\end{array}$} & $t$ & 2 & 98 & 100 & $49,7 \%$ \\
\hline & $d$ & 4 & 6 & 10 & $4,9 \%$ \\
\hline & $\mathrm{n}$ & 0 & 10 & 10 & $4,9 \%$ \\
\hline & $\mathrm{s}$ & 0 & 2 & 2 & $0,9 \%$ \\
\hline & $z$ & 1 & 4 & 5 & $2,4 \%$ \\
\hline & ᄃ & 5 & 8 & 13 & $6,4 \%$ \\
\hline & 1 & 4 & 12 & 16 & $7,9 \%$ \\
\hline \multirow{7}{*}{$\begin{array}{l}\text { Palatais e } \\
\text { velares }\end{array}$} & $\mathrm{k}$ & 0 & 0 & 0 & $0,0 \%$ \\
\hline & $\mathrm{g}$ & 0 & 1 & 1 & $0,4 \%$ \\
\hline & $\mathrm{n}$ & 0 & 1 & 1 & $0,4 \%$ \\
\hline & $\int$ & 2 & 7 & 9 & $4,4 \%$ \\
\hline & 3 & 2 & 4 & 6 & $2,9 \%$ \\
\hline & $x$ & 0 & 0 & 0 & $0,0 \%$ \\
\hline & $\Lambda$ & 0 & 0 & 0 & $0,0 \%$ \\
\hline \multirow{5}{*}{ Vogais } & $\mathrm{e}$ & 0 & 0 & 0 & $0,0 \%$ \\
\hline & $i$ & 0 & 0 & 0 & $0,0 \%$ \\
\hline & $a$ & 0 & 1 & 1 & $0,4 \%$ \\
\hline & 0 & 0 & 0 & 0 & $0,0 \%$ \\
\hline & $\mathrm{u}$ & 0 & 2 & 2 & $0,9 \%$ \\
\hline \multicolumn{2}{|c|}{$\#$} & 1 & 2 & 3 & $1,4 \%$ \\
\hline \multicolumn{2}{|c|}{ Total: } & 33 & 168 & 201 & $100 \%$ \\
\hline \multicolumn{2}{|c|}{ Porcentual: } & $16,4 \%$ & $83,5 \%$ & $100 \%$ & \\
\hline
\end{tabular}


Os étimos de palavras em -ingo(s) são os mais variados e o valor pejorativo é bastante atenuado de modo geral. São deverbais 1899 gingo, 1881 respingo, xingo, choramingo, 1899 ginga, 1593 pinga, a1748 rezinga. O valor positivo se vê em 1881 pingo "cavalo de qualidade, bonito e corredor". Aparentemente, as formas em -ingo atenuam a generalização do traço nasal para -Vngo. No entanto as formas em -inga(s) são mais propensas à pejoração: de choramingo advém 1666 choramingas (donde choramingão, como em chorão). Como comprova o quadro acima, muitas palavras derivam-se do tupi tínga "branco". O valor pejorativo se encontra em:

- Imperfeições físicas ou morais: bujinga "monte de lixo, de coisas imprestáveis", catinga "avarento" "avareza" 1720 seringa "indivíduo importuno ou esquisito"; 1899 curinga "indivíduo feio e raquítico", 1618 peitinga, 1720 petinga ou 1886 pitinga "peixe miúdo usado como isca" "negócio sem interesse", pixilinga ou pichilinga "coisa muito pequena", 1593 pinga "pessoa bêbada";

- Certas profissões que envolvem violência ou sexo: cainga "policial";

- Nacionalidades: séc. XIX gringo "estrangeiro diferente do padrão encontradiço no país" e em 1899 jingo "defensor da guerra inglesa contra a Rússia em 1878" "patriota fanático";

- Apreciação negativa de ações: d1671 muxinga "surra";

- Pobreza: fandinga "maltrapilho", 1593 pinga "pessoa que não tem dinheiro";

- Bebidas alcoólicas: jurupinga, lapinga, 1593 pinga, zuninga;

- Religião e crendices: caninga "má sorte" "desgosto, aborrecimento", 1716 mandinga ou maninga;

Acúmulo de significados de várias categorias podem ser visto em palavras altamente polissêmicas como: 1899 binga "matéria fecal" "coisa emprestável", "pênis de criança ou pouco desenvolvido" "marido traído" "pessoa reles"; cafuringa "coisa pequena e sem importância" "mexeriqueiro" "carapinha" "automóvel velho". 
Completando as listagens, observe-se que formas derivadas em -Vnguinho(a)(s) não dão grandes pistas semânticas, embora haja exemplos com aglutinador pejorativo, como dunguinha "pessoa de pouca importância", canguinha(s) "pessoa pequena", "pessoa fraca", "pessoa sovina". Já as em -Vnguice (com o sufixo -ice, potencializador do valor pejorativo) são: candonguice (1873 o mesmo que 1727 candonga "ardil"), moganguice (séc. XX, o mesmo que 1716 moganga, muganga, munganga, séc. XVII mogiganga, mungango ou mugango "movimento excessivo das mãos ou do rosto", "careta", "lábia", também sob a forma mocanguice e muganguice), denguice 1836 "comportamento sedutor", "ostentação", "gestualidade afetada", "ardil", "lamentação infantil”. O aglutinador pejorativo afeta também a interpretação de outros sufixos ou justamente se adapta melhor a elas, como punguista "batedor de carteiras" 1899 (de punga 1842, com o mesmo sentido), mogangueiro 1789 ou moganguista "quem faz mogangas".

Ainda com base nos dados do Houaiss, observa-se que o grande grupo das formas com vogal não-anterior são de longe as mais prolíficas, como se pode ver no gráfico a seguir que revela os verbetes com terminação $-\operatorname{Vngo(a)(s):~}$

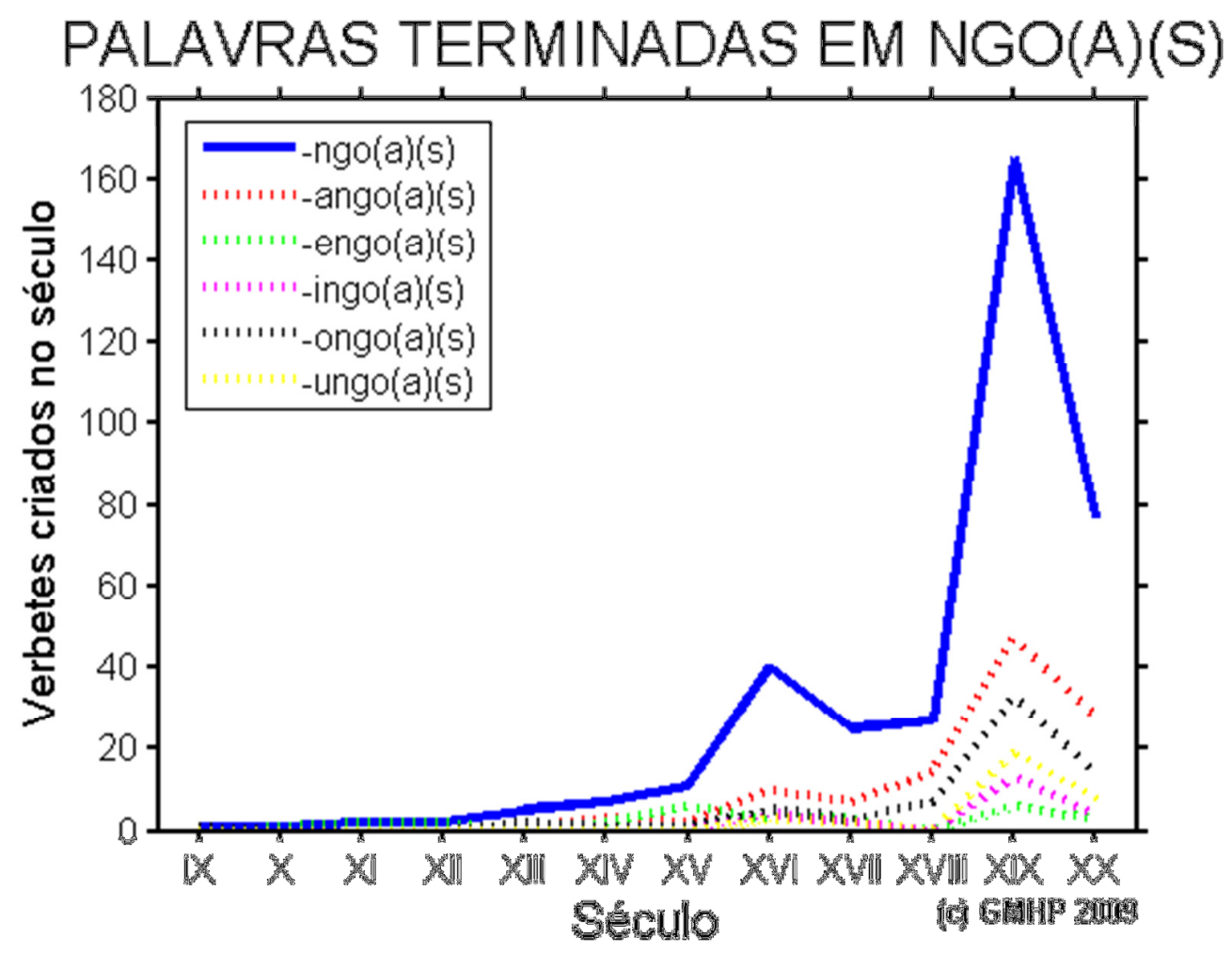

Gráfico 3 - Palavras terminadas em -Vngo(a)(s) 
Hoje, palavras com a terminação -engo(a)(s) são claramente as menos prolíficas de todas, seguido de -ingo(a)(s). Aparentemente, vogais não-anteriores nasais cumprem melhor a função que a neologia Ihes vem atribuindo na gênese de sufixos com valor pejorativo por meio de aglutinadores pejorativos.

Por semelhança ao sufixo -engo(a)(s) surgiram outras formas em que a terminação $-\operatorname{Vngo}(a)(s)$, aparentemente restrita à Lexicologia, atua como um verdadeiro sufixo e, portanto, seria algo morfologicamente interessante, apesar de não terem sido encontradas formas com um sufixo -*ungo(a)(s).

Caranga "automóvel": o aspecto sufixal da terminação se entrevê em caranga, 1873 charanga ou 1873 carango "automóvel" assim como, talvez, em azango.

Riponga "hippie": o termo riponga dicionarizado (também sob a forma ripongo) mostram a existência da produtividade do sufixo e seu significado pejorativo (para além de simplesmente ser um aglutinador pejorativo) na segunda metade do século $X X$, após a divulgação internacional do termo inglês hippy ou hippie (atestado em inglês em 1953): 1979 José Carlos Oliveira O saltimbanco azul: crônica dos acontecimentos atuais: "Abri e as duas despencaram pelo vão da porta. Estavam completamente embriagadas, as duas ripongas" 1979 p. 125, mas cf. Istoé - 1370/8 1975 pág. 38: "Para os naturalistas americanos e herdeiros da geração riponga, a planta é muito mais do que apenas fonte do bom e velho baseado;

Choramingas "chorão" (século XVII a1666) - teria sido nasalização de choramigas?,

Durango "duro, i.e. sem dinheiro" (2000 século XX cf. TermNeo "A Vera deveria ter casado com o Mick Jagger, e não com um durango que nem eu." Jace Valadão ... Veja, 27.12.2000),

Coxanga "coxo" (s/dat, cf. coxambeta, com o mesmo significado),

Nariganga "aquele que tem nariz grande, narigão" (século XIX 1899),

Molhanga "grande quantidade de molho, molho grosso ou muito condimentado" (Guerreiro 1784: 115),

Japoronga "japonês" (1990 século XX). 
Quando se criou a palavra japorongo, o seu valor pode transitar entre áreas muito fluidas que vão desde a familiaridade até o preconceito. 0 jogo social implicado na utilização da palavra na parole, em contexto real específico (associado a fatores de prosódia) é que determinarão o exato aglutinador avaliativo, uma vez que a palavra sequer é dicionarizada, embora perfeitamente detectável em corpora extensos, como se pode perceber em milhares de ocorrências no Google (tanto no masculino quanto no feminino, tanto no singular quanto no plural). Além da terminação -ngo $(a)(s)$, na variante vocálica -o-, percebe-se claramente a intromissão de um interfixo -or-, o que supõe que talvez a palavra tenha tido interferência analógica de outra palavra mais antiga. Como visto, o dicionário Houaiss aponta 10 palavras terminadas em -orongo. A gênese de orongo que se aglutinou à raiz jap- (e não a japon-), mostra que, por meio do mecanismo analógico, -orongo sofreu aquilo que poderíamos de chamar de semanticização da terminação previamente átona. O seu emprego neológico que permite avaliar que foi assim a gênese lexical de japorongo. Dito de outra forma: sufixos podem não ter necessariamente um étimo, mas podem emergir como resultado de um fenômeno analógico. Isso, longe de invalidar, a necessidade e até mesmo a pertinência de uma Morfologia Histórica com vistas ao estudo dos elementos de composição, pelo contrário, enriquece e complexifica, por meio de dados, a necessidade de uma reavaliação do método diacrônico, no intuito de confirmá-lo e não de rejeitá-lo. Assim, o caso de japorongo corrobora a linguística diacrônica, por mais difícil que seja rastreá-lo.

Aparentemente, algo parecido aconteceu com uma base germânica que fortaleceu um sufixo -ingo em italiano: casalingo "relativo à casa", ramingo "pássaro que voa de rama em rama". Para além dos dados do Houaiss, podemos falar de outras formações. Leite de Vasconcelos (1928:431-434) cita as palavras cristengo (cast cristianiego), judengo (cast judiego), em que haveria um "falso sufixo -engo", porque viria de -aecus > -ecus $\rightarrow$ an+ecus > -*aengo > -engo. Cf. -ego em cast labriego, port labrego; cast mujeriego, port mulherengo; cast solariego, port solariego, solarego, solarengo, solariengo ("puro hespanhol"). cf. manchego, galego. Outras formas se entrevêem esporadicamente: pelanga, fritangada, pernangoila, festanga, festangada, chiangar [Revista Lusitana 1890- 
1892(2):247; Romania 1922(48):121; ZfRP 1944(24):324; Revista Portuguesa de Filologia 1968(1-2):25,103,122].

É possível aumentar a generalização e imaginar que a terminação em questão é um subcaso de uma mais ampla, a saber, -'VNCV, em que $\mathrm{N}$ seria uma consoante nasal qualquer (ou arquifonema nasal) com os traços de $C$, o qual teria ao menos os traços [+oclusiva] e [+velar], bem como [ \pm sonoro]. De fato, vê-se algo muito próximo no sufixo anca de, por exemplo, pelanca. Algo semelhante parece acontecer sem tanto êxito com formas em - $\operatorname{Vmbo}(a)(s)$ : grandumba "que ou aquele que é grandalhão", típico do Rio Grande do Sul (Oliveira, 2002; razões talvez se encontrem em Viaro \& Guimarães-Filho 2007, 2011).

Se nos ativermos à terminação -Vngo(a)(s) ou mesmo ao simples encontro -ng-, veremos que há grande produtividade do valor da pejoração. No léxico de Guimarães Rosa, sobretudo em seus neologismos, encontram-se em Martins (2001) palavras como: adengar, alvarenga, anhanga, aslongas, bambalango, bedelengar, bendengo, bengo, brongo, calungado, candonga, carangonço, caxerenguengue, choramingudo, clingo, cramondongue, descangar, drongo, dunga, encarangado, engronga, eslinga, espandongado, esverdolengado, gangolô, gungo, ivitinga, jaguacininga, langue, lenga arenga, malungo, mamolengo, mangangaba, matungo, mengo, merenguém, mingrim, mocangueiro, mocorongo, mongo, mongoar, mossorongo, mostrengar, musgoengo, nhenganhenga, pedroenga, perrengue, piongo, pirunga, pongo, pongudo, puçanguara, quenga, remangar, saçanga, sambanga, sanga, sapiranga, saranga, sengo, serenga, surunganga, tchungar, trapizonga, tungar, urumicanga, vinga, virundanga, sem falar de casos com outra oclusiva como renquetrenque, berimbar, jerimbamba, mambembe. A produtividade da expressividade desses encontros é bastante visível a partir do século XVIII (cf. Guerreiro 1784). Alguns dicionários voltados à gíria têm grande número de verbetes com o mesmo elemento expressivo: araponga, arenga, arumangado, baranga, bicanca, binga, bruzundanga, buchunguinhas, buzanfar, cachanga, cafungador, cafungar, capanga, capenga, caramingootes, caraminguá, caranga, catinga, catingudo, catinguento, caxanga, caxangar, caxangueiro, charanga, chibungo, curinga, duranga, durango, 
fandango, fedengoso, furingo, jacutengo, japoronga, lengalenga, miçanga, milonga, mironga, mocoronga, molenga, mondrongo, moganga, muringa, perrengue, pingapinga, pintinga, reguenguelo, samango, songamonga, tibungo, tonga da mironga, trapizonga, uengotchengo, zongar (Serra e Gurgel $1995^{3}$ ); baitinga, baranga, candanga, fubanga, monga, munganga, patchonga, perrenga, pirangagem, pirangueiro, podenga, tanga, tchonga, xibungo, xoronga (Vip \& Libi, 2006). Como na gíria, tais palavras têm grande representação, os autores desses dicionários, sem nenhum método de delimitação do elemento neológico caracterizador da gíria propriamente dito, valem-se da sonoridade. Mesmo palavras antigas como songamonga são classificadas como giriáticas, dado o equívoco natural decorrente do desconhecimento histórico que o falante nativo tem de sua língua. $\mathrm{O}$ caso de fedengoso em vez de fedegoso aponta para uma analogia motivada duplamente no nível do significante (com a palavra dengo e com as acepções pejorativas das palavras com -ng- ). Também durango, forma sufixada de duro, valeu-se do emergente sufixo -ango associando-se, impressionisticamente, ao mesmo tempo, com o topônimo Durango, divulgado na forma da personagem Durango Kid.

Entre outros processos da gíria, encontram-se a deformação do radical (figueiredo em vez de fígado), as mesclas (como em intelijumento) e novos sufixos como-VIdo(a)(es), extraído de nomes próprios ${ }^{11}$. Dessa forma, a alta frequência, a expressividade, a analogia e a falsa segmentação tem grande papel na formação de novos sufixos.

Nas palavras acima listadas, vê-se em baitinga, que segmentou um falso radical a partir de baitola (e, de fato, essa palavra aparece na definição fornecida pelos autores: "baitola baixa, bicha rés-do-chão"). Uma palavra como patchonga, sinônima de tchonga, (possivelmente mesclada com a palavra pata "pateta"), vale-se de outra mais antiga, monga, que tem uma etimologia (de fato, mongo parece ser redução de mongoloide), mas tchonga aproveita-se ainda da sonoridade, a qual reforça com um tch- também presente na palavra tchenga, abonada na frase pega logo essa tchenga e não me enche o saco

\footnotetext{
11 a saber, chatonildo, bruxildes, escrotilda, espertildo, fomizeldo, safanildo, jumentildo, jumentonildo, otarildo, putonildo, sacanildo.
} 
(Fernando Gonsales - Níquel Náusea - Folha de São Paulo, 10/01/2003, ilustrada E7) ${ }^{12}$. O mesmo tch- expressivo surge em realizações especiais do fonema /t/, como tchurma "turma" e em mintchura "mentira". O resultado é que vemos um sufixo -onga em patchonga que não aparece nem em monga ou em tchonga, que a criaram. Também em bicanca encontra-se a base bico "chute forte" e uma variante -anca que se encontra em metranca "metralhadora", por exemplo. Entre as palavras criadas por Guimarães Rosa, encontram-se neologismos com sufixos claramente pejorativos: musgoengo "musgoso, musguento", pedroenga "pedreira" e elementos expressivos como tchungar "pegar".

Desse modo, não é possível atribuir origens africanas a toda e qualquer palavra de étimo pouco claro que se componha de $-n g-,-m b-,-n c-$ etc., como é a prática corrente (cf. Lopes, 2003). Um valor que mistura sinestesicamente coloquialidade, movimento, pejoratividade estão na gênese de formas produtivas. Se, por um lado, somente pela depreensão de sufixos podemos provar essa afirmação, a reiteração de valores e significados de forma analógica podem, de outro, dar azo a hipóteses plenamente justificáveis que, apesar de não invalidarem totalmente a questão da arbitrariedade do signo, traz à luz de modo sério a discussão milenar da associação de sons a significados, a qual pode se beneficiar dos estudos linguísticos histórico-comparativos e dos estudos da psicologia dos últimos dois séculos.

Com relação a palavras que possuam o encontro -ng- distribuídas por século ${ }^{13}$, vemos, no corpus do dicionário Houaiss as seguintes quantidades:

\begin{tabular}{|c|c|c|}
\hline Século & Quantidade & $\%$ \\
\hline XI & 2 & $0,09 \%$ \\
\hline XII & 2 & $0,09 \%$ \\
\hline XIII & 42 & $1,9 \%$ \\
\hline XIV & 20 & $0,9 \%$ \\
\hline
\end{tabular}

\footnotetext{
12. Essa palavra tchenga parece ser apenas uma criação expressiva e um sinônimo contextual de "coisa" com valor depreciativo. Aparentemente não tem história, pois foi criada pela parole, a partir do mesmo molde fônico que gera o sufixo -Vngo

${ }^{13}$ excluindo 4017 casos em que a grafia equivale a /N3/, / Ngr/ e /Ngl/.
} 


\begin{tabular}{|c|c|c|}
\hline XV & 25 & $1,13 \%$ \\
\hline XVI & 102 & $4,62 \%$ \\
\hline XVII & 76 & $3,44 \%$ \\
\hline XVIII & 100 & $4,53 \%$ \\
\hline XIX & 473 & $21,46 \%$ \\
\hline XX & 330 & $14,97 \%$ \\
\hline desconhecido & 1032 & $46,82 \%$ \\
\hline Total & 2204 & $100 \%$ \\
\hline
\end{tabular}

Essa discussão também leva em conta a questão da existência dos dados em linguística. A partir dos dados apresentados, como negar que exista de fato um sufixo $\operatorname{Vngo}(a)(s)$ ? Palavras usadas em outras épocas, criadas por um escritor, produzidas em contextos distintos dos com os quais estamos acostumados certamente também existem. No entanto, por mais razoável que seja essa afirmação, por mais que possamos comprovar a existência (e a frequência) por meio de mecanismos de busca da Internet (Google, Bing, Yahoo), ainda assim, algum idealismo com pretensões dedutivistas ou algum caráter normativo vaugelaisiano impele os estudos linguísticos a não trabalhar desapaixonadamente com os dados linguísticos. Maior prova disso é a insistência no uso do asterisco para "forma inexistente", levando-se em conta pura e simplesmente a vivência do falante-juiz. Além de redundante e paradoxal (não é possível combinar estudos históricos e gerativistas, por exemplo, sem criar confusão no uso do asterisco, que na sua acepção schleicheriana mais antiga significa "forma não atestada nos documentos"), o descuido com o formalismo e a falta de critérios para a terminologia emperram o diálogo entre as correntes da linguística e não constituem, assim, um passo rumo à integração em teorias unificadas. Uma palavra como grandura não existe no Houaiss, pode ser "sentida" pelo falante como neologismo ou até mesmo provada por um recorte metodológico qualquer, mas a verdade científica está acima de impressões e métodos, pois devia estar apoiada em dados e, de fato, grandura já aparece no dicionário de Jerônimo Cardoso, de 1570. Se a palavra já está abonada há mais de cinco séculos e se 
aparece em inúmeras páginas da internet, por que dizer - a não ser por uma sensação vaga e subjetiva - que a palavra não existe? O mesmo podemos dizer de sufixos como ongo. A falta de uma base epistemológica clara gera, de fato, a dificuldade aparente ao diferenciarmos semantica- e funcionalmente um sufixo de uma terminação sem significado. Postular uma origem múltipla para a expressividade de $-n g o(a)(s)$ parece realista, no entanto, como lidar com a homonímia na gênese e com a multiplicidade semântica dela decorrente é algo que vem preocupado alguns autores (Condé 2008; Gonçalves 2009; Viaro 2010). Outro estudo necessário é o papel do significado da palavra como fonte de geração do significado de sufixos emergentes. Por fim, o estudo dos moldes fônicos na formação desses mesmos significados (Viaro \& Guimarães-Filho 2010; Viaro 2011), da prolificidade do sufixo e da frequência de uso são de importância muito grande para a formação dessa ambicionada base epistemológica. Perante tudo isso, é possível apresentar algumas hipóteses que encaminhariam a discussão para a obtenção desses pressupostos, a saber:

- Quanto maior a ocorrência de uma palavra, mais chance haverá da palavra continuar existindo. Os extremos na questão da frequência de uso seriam uma palavra criada num único ato de fala (neologismo não-aceito) e uma palavra presente em praticamente todos os atos de fala (por exemplo, os artigos definidos). Portanto, teoricamente pode-se dizer que, dados todos os atos de fala num momento M1 e dados todos os atos de fala num momento M2 subsequente, pode-se dizer que M1 permanece constante, diminui ou aumenta;

- Como não é possível termos todos os atos de fala (huge chart Bloomfield 1933:46), mas apenas alguns e desses, ainda, apenas uma amostragem pequena é analisada (a saber, os corpora), portanto, a inexistência de uma palavra num corpus não implica na inexistência da palavra de modo geral;

- Uma vez que um corpus é uma coleção de textos (que são, em última instância, atos de fala), um fenômeno linguístico qualquer investigado nele pode ocorrer de forma variada: uma palavra pode ocorrer poucas vezes num único texto, uma palavra pode ocorrer muitas vezes num único texto, uma palavra pode ocorrer poucas vezes em muitos textos, uma palavra não ocorre nenhuma vez em nenhum texto, a palavra ocorre muitas vezes em muitos texto);

- No caso de a palavra ocorrer em alguns textos, também é possível imaginar a situação de esses textos serem sobre assuntos distintos ou sobre o mesmo assunto (o que requer uma tipologia textual para determinação dos contextos de ocorrência). Por exemplo, o sufixo ídeo tem, nos dicionários, muitos verbetes, mas todos são pouco frequentes no universo de textos que não tratem de Biologia. Um sufixo $-V n g o(a)(s)$ é mais frequente em textos que versem sobre temas do quotidiano menos especializados, daí o tom mais coloquial atribuído a ele. 
Se houvesse apenas 4 textos no mundo, que pudessem ser classificados em dois tipos $a$ e $b$, ou seja: $a 1, a 2, b 1, b 2$, diríamos que seria um hapax aquela palavra que ocorresse uma única vez em apenas um dos quatro textos e diríamos que é uma palavra universal se aparecesse muitas vezes nos quatro textos. Se ocorresse uma única vez em a1 e uma única vez em a2 seria um caso raro e tipologicamente definido (pois não ocorre nem em b1 nem em b2); se ocorresse muitas vezes em a1 e a2 seria uma palavra típica de textos $a$. Se ocorresse uma única vez em a1 e uma única vez em b1 diríamos que é uma palavra também rara, mas mais representativa (pois ocorre em textos do tipo a e do tipo b). A representatividade aumentaria se a mesma palavra aparecesse uma vez em a2 e mais ainda se também aparecesse em b2. Quanto mais vezes a palavra aparecesse em mais de um texto, maior seria sua representatividade. No entanto, se a palavra aparecesse muitas vezes só em a1, a palavra seria característica desse texto e possuiria um caráter marcadamente estilístico.

A partir disso, podemos concluir que a representatividade de uma palavra é diretamente proporcional à frequência de ocorrências em muitos textos de muitos tipos. Já a especificidade de uma palavra é inversamente proporcional à quantidade de tipos de texto (independentemente da frequência de ocorrências). Os casos extremos seriam o hapax e a palavra universal, que seriam respectivamente objeto de estudo da Estilística e da Gramática. Todos os demais casos seriam objeto de estudo da Lexicologia (e da Morfologia, se o fenômeno for, por exemplo, um sufixo). 


\section{ACERCA DE UMA METODOLOGIA PARA O TRABALHO COM SUFIXOS}

Como se pode perceber, uma vez abandonado o cômodo critério do falante-juiz, para desenvolver-se um bom banco de dados de onde se aufiram informações relevantes para considerações em Morfologia Histórica, é preciso que haja uma metodologia rigorosa. A datação de palavras em língua portuguesa, longe de ser uma tarefa que diz pouco aos estudos linguísticos, revela-se importante para assuntos que envolvem a morfologia e a lexicologia. Nesse sentido, Antônio Geraldo da Cunha (1924-1999) talvez tenha sido um pioneiro em língua portuguesa. Antes dele, José Pedro Machado (1952-1959), embora tenha oferecido fartas abonações, indicava, na maior parte das vezes, apenas o século da primeira ocorrência. Já se veem algumas datações específicas no dicionário etimológico de Cunha (1982). Principalmente seu dicionário etimológico de palavras de origem tupi (1978) espelha seu extenso trabalho, que espera uma publicação integral e que equipararia a língua portuguesa à espanhola, uma vez que ainda não dispomos de um dicionário etimológico com a qualidade de um Corominas (1954-1957). Toda a pesquisa de Cunha encontra-se, ainda, sob a forma de fichas, na Casa Rui Barbosa, no Rio de Janeiro, com publicações parciais na década de 80 e de 90. Parte substancial dos dados aparece no dicionário de Houaiss \& Villar (2001) e no Vocabulário Histórico-Cronológico do Português Medieval (2006).

A questão da data, presente há muito tempo em dicionários ingleses, franceses e italianos (até mesmo para acepções das palavras) é de suma importância para os estudos linguísticos históricos. A data que aparece nos dicionários rarissimamente é, de fato, a data da invenção da palavra (isso só pode de fato ocorrer com neologismos recentes), mas no mais das vezes, trata-se de uma data dependente de corpora. Desse modo, é possível retroagi-la à medida que se descubram novos textos, que os investiguem e organizem seu material lexicológico. Julgamos, porém, que as datas constantes no dicionário Houaiss sejam um ótimo ponto de partida para investigações parciais, muito embora haja lacunas enormes em alguns séculos (sobretudo os não investigados por Cunha) e ausência de datas específicas para o século XX. Lamentavelmente, muitas pessoas conhecem a 
existência de uma ou mais datas erradas no Houaiss, conseguindo retroagir, com seus próprios corpora. Essa informação não é sistematicamente coletada ou disponibilizada aos especialistas. O dicionário Houaiss de 2001, não pretendendo ser, de fato, um dicionário etimológico, apesar da longa e inédita discussão etimológica que promove em cada verbete, por razões editoriais, não dispõe de abonações, como ocorre com o dicionário de Machado. O ideal seria que juntássemos as datas mais recuadas com suas respectivas abonações, para todas as palavras do português em um único banco de dados, disponibilizado para todos que quisessem colaborar. Sabemos que a data, como dito, não revela o nascimento da palavra, mas o fato de ela já existir naquela época de sua abonação. Com base nessas informações, por exemplo, Väänänen (1985) conseguiu reconstruir boa parte da sincronia pretérita do latim vulgar. No português, entrevê-se, de forma ainda incipiente, alguns fenômenos de sincronias pretéritas, em Teyssier (1980).

Isso posto, surge o problema dos corpora. Como as datações, essas coletâneas trabalhosas são ainda muitas vezes tratadas como propriedade individual (a despeito de haver muitas vezes investimento de órgãos públicos de pesquisa). Hoje em dia, a forma mais democrática de disponibilizar os corpora, sem dúvida, é, no entanto, a rede internacional de computadores (internet). A própria rede passa a ser um imenso corpus com a desvantagem de sua imensa mobilidade. É possível abonar inúmeros fatos difíceis de ser obtidos em corpora, mas, mesmo por meio dela, é dificultoso o trabalho de datação: as palavras podem ficar décadas online, mesclando o novo com o velho, numa pancronia caótica. Na verdade, hoje em dia, praticamente tudo pode ser encontrado por meio de buscadores, como o google. Além disso, muitos sites constituem verdadeiros mecanismos de pesquisa. Um deles, especialmente útil para a Etimologia e para o nosso trabalho é o Google Books.

Mais difícil que a reconstrução do significado das palavras em sincronias pretéritas é a reconstrução da sua diacronia. Aparentemente as palavras já nascem polissêmicas. A monossemia é sem dúvida uma abstração e nunca a encontraríamos, nem se recuássemos ao início da fala humana. De fato, é uma ilusão criada pelo método dedutivo. O signo não nasceu para a monossemia, pelo contrário, o ser humano só fala por ter criado um 
mecanismo simbólico. Talvez somente os nomes próprios, como se discute em ontologia, têm a prerrogativa de - às vezes - ser construídos para apontarem para referentes reais em vez de para o significado, entendido necessariamente como socialmente construído.

Morfemas - no sentido estruturalista - possuem, nesse sentido, um significado. Embora um radical muitas vezes não tenha vida independente senão complementado por outros morfemas que o rearranjem num sistema, disporá de um significado adquirido diacronicamente, tanto na passagem de uma geração a outra, durante sua aquisição, quanto na própria vida de cada indivíduo que - com maior ou menor êxito - o modifica. 0 mesmo se pode dizer de morfemas gramaticais, apesar de um pouco mais resistentes.

O português, juntamente com grande parte das línguas indo-europeias, dispõe de um complexo sistema de sufixação derivacional. Seu uso na formação lexical, apesar de frequente, não é universal. Há tempos se sabe que nem todas as línguas humanas possuem sufixos derivacionais. Também a manifesta polissemia apresentada na sufixação portuguesa não é algo que ocorra tão evidentemente com outras línguas que possuem sufixos (como o turco). E do ponto de vista dos próprios sufixos, nem todos têm o mesmo comportamento. No entanto, esses três pressupostos (a universalidade da sufixação, a polissemia intrínseca e o comportamento comum) são amiúde pressupostos em modelos preponderantemente dedutivos. A razão disso repousa numa postura generalizante com relação aos sufixos que tem suas raízes na gramática tradicional e não foi suficientemente superada.

Por meio de planilhas e listas exaustivas extraídas de dicionários, as seguintes indagações devem ser respondidas para cada vocábulo que disponha de um suposto sufixo:

a) qual a palavra analisada?

Neste campo da planilha, simplesmente, entraria o vocábulo que supostamente possui o sufixo devido à sua terminação. Uma planilha do sufixo-eiro, por exemplo, é composta exclusivamente de palavras terminadas em -eiro, -eira, -eiros, -eiras, -eirinho, - 
eirice, -eireiro, -eirar etc. Por cautela - para não se fazerem generalizações indevidas - não entram nela palavras com outros sufixos, ainda que com a mesma etimologia: tanto -eiro quanto -ário são formas divergentes do mesmo étimo latino (-arium), mas formam duas planilhas distintas. Observou-se que quando o sufixo não é final, muitas vezes, conservamse características semânticas antigas extremamente desejáveis à pesquisa (pois revelam uma etapa anterior à nova sufixação que ocupa posição final), contudo sua depreensão é mais complexa, pois as listagens automáticas não as revelam rapidamente e os buscadores se tornam ainda menos eficientes por listarem elementos da raiz (numa busca automática por -eir- por exemplo, aparecem palavras como beirada), sendo necessário coletá-los um a um, razão pela qual normalmente caracterizam uma segunda etapa - mais avançada - de investigação.

b) de qual sufixo se trata?

É sabido que há dois fenômenos importantes detectados pela Linguística Histórica há muito tempo: a convergência e a divergência. Muitas palavras com uma terminação idêntica não possuem necessariamente o mesmo sufixo. Dessa forma, nem toda palavra terminada em -eiro tem de fato um sufixo -eiro, diacronicamente falando. Pode ocorrer uma coincidência de formas: o tupi makaxéra gerou macaxeira, portanto, a terminação éra em tupi não equivale ao mesmo sufixo de pereira, por exemplo, que proveio do latim * pirariam. A rigor, a palavra macaxeira não deveria ser analisada. O caso da convergência de formas é, contudo, bastante intrigante, pois há, sabidamente, o fenômeno da etimologia popular, como vimos no capítulo anterior, acerca de $-V n g o(a)(s)$, não sendo impossível haver convergência semântica posterior paralelamente à convergência formal. Outros sufixos portugueses se formaram por meio da convergência de dois ou mais sufixos latinos. Distinguir o sufixo típico de eventuais casos convergentes, por meio da origem, torna-se o primeiro passo para estabelecer a genealogia das mudanças semânticas. Também a divergência é importante e motivada sobretudo pelo cultismo. Desse modo, podemos dizer que o grego -ápıov ou o latim -orius e -arius, em algumas 
palavras, convergem em três sufixos -eiro homônimos (vide capítulos 5 e 6), cuja mescla semântica está longe de ser excepcional, da mesma forma que o -arius latino se diverge em -ário e -eiro em português, cujo paralelismo semântico também se pôde detectar. Separar os três -eiro no primeiro caso e juntar os dois sufixos provenientes de -arius no segundo afigura-se um passo metodológico importante, antes de se chegar a conclusões.

c) qual a classe morfológica do resultado?

A palavra resultante da sufixação pertence a uma ou mais classes morfológicas. Elas precisam ser discriminadas, para saber se se trata de um sufixo nominalizador, adjetivador, verbalizador ou adverbializador. 0 mesmo sufixo pode ter várias funções. Entendemos que essa função está estritamente ligada às classes morfológicas e, como tal, não esgotam o valor semântico do sufixo, de modo que se distinguem função e significado do sufixo. Essa distinção é feita com maior ou menor clareza, dependendo do sufixo envolvido. Normalmente sufixos formadores de abstratos deverbais, por exemplo, se voltam exclusivamente para a função, enquanto outros, como o -eiro formador de nomes de árvores frutíferas, além de nominalizadores, possuem uma carga semântica própria. Prova disso é que formam substantivos concretos, cujo gênero, no sentido aristotélico (ou hiperônimo, no jargão linguístico) se deve mais ao sufixo do que ao radical. Por exemplo, pedreiro é uma profissão por causa de -eiro e não um mineral, por causa do radical pedr-. Isso ocorre com muitos sufixos derivacionais nas línguas indo-europeias.

d) qual o étimo da palavra?

Trata-se de uma etapa extremamente importante para a Morfologia Histórica, uma vez que se investiga, quando possível, a palavra que deu origem ao vocábulo. Apenas no caso de falta de étimo propriamente dito, escolhe-se a base primitiva sobre a qual a derivada se formou. Nesse caso, estaríamos perante uma derivação proprimente dita. 
Assim, de mangueira, extrai-se manga. Já no caso de palavras vindas do latim, independentemente de a fonte ser segura ou reconstruída, trabalha-se com o étimo da palavra e não com o radical. Assim, cavaleiro não viria de cavalo, mas do latim caballarius da mesma forma que pereira não provém de pera, mas do hipotético latim *pirariam (porque a forma ocorre também em outras línguas românicas). 0 resultado da análise semântica dessa decisão mostra produtividades iniciadas em distintas sincronias.

O mesmo ocorre com os empréstimos. No caso de palavras vindas de outras línguas, segue-se o padrão internacional ISO 639-2 para siglas de línguas (constante em http://www.loc.gov/standards/iso639-2/php/English_list.php) juntamente com étimo. Assim, bastonada, que vem do francês bastonnade é indicado na planilha como frebastonnade. Se não houver certeza da etimologia, o campo tem sido deixado em branco até que se efetue uma análise detalhada do vocábulo. Nos casos de raiz determinável, mas sem associação direta a uma palavra existente em português, latim ou outra língua, convencionou-se anotar apenas o radical, ainda que vazio. Dessa forma, para carpinteiro, o étimo preferível é carpint- e não carpintaria, uma vez que ficaria inexplicada a subtração de um sufixo por outro. Também o étimo de correria seria corr- e não correr. Quando houver caso de convergência com palavras sem sufixos (como o caso de macaxeira, acima descrito), convencionou-se que este campo ficaria vazio.

e) qual é o processo de transmissão?

Para refinar as informações acima, é preciso saber se a palavra é de fato vernácula ou é um empréstimo e no caso de provir do latim, de qual variedade específica (popular, clássico, medieval ou científico). A separação da pergunta $d$ e $e$ tem fins estatísticos.

É uma prática tão antiga quanto abusiva, indicar o étimo pelo acusativo latino, uma vez que as formas no acusativo refletem apenas palavras do latim vulgar, mas nem todas as palavras de origem latina tiveram um único modo de transmissão. Dessa forma, somente os termos em latim popular mereceriam esse tipo de notação (nesse caso, tampouco se indica a apócope do $-m$ ), uma vez que formas cultas, medievais e científicas 
não passaram pelas mesmas regras fonéticas das formas populares e, portanto, deveriam ser indicadas no nominativo. A facilidade de padronização conduz a leituras errôneas com relação à transmissão. Quando não se sabe exatamente qual foi o processo de transmissão (por causa da indefinição das leis fonéticas) preferiu-se a indicação no nominativo, mesmo para os casos dos termos semi-eruditos.

f) qual é o grau de certeza dessa etimologia?

A ideia do grau de certeza etimológico aparece em Jespersen (1922:307, nota 1):

It is of course, impossible to say how great a proportion of the etymologies given in dictionaries should strictly be classed under each of the following heads: (1) certain, (2) probable, (3) possible, (4) improbable, (5) impossible - but I am afraid the first two classes would be the least numerous.

O emprego tradicional do asterisco, em linguística histórica, ou de pontos de interrogação, tem ambiguidade indesejável numa pesquisa que se pretende mais cautelosa. Quando o étimo existir de fato em documentos e a ele apenas se aplicam as leis fonéticas para explicar a forma da palavra portuguesa, dizemos que ele é seguro, ainda que o significado da palavra em questão se tenha modificado. Nessa categoria estaria, portanto, tanto a palavra sensível, que viria do nominativo sensibilis, com o mesmo sentido, quanto cavaleiro, que viria do acusativo caballarium, mas significava "criador de cavalos".

Diz-se que o étimo é hipotético, quando reconstruído a partir do português e das outras línguas em que a palavra foi difundida (românicas ou não). Quanto maior o número de línguas envolvidas nessa reconstrução (excluído o caso de divulgação por empréstimo), mais próximo esse étimo estará do título de seguro. Igualmente seguro é o caso dos étimos provenientes de línguas marginais, reforçado pela falta de contato entre as línguas, excluída, como sempre, a hipótese do empréstimo. Assim, um étimo reconstruído a partir apenas do português é pouco seguro, pois a reconstrução seria ad hoc. Outro, feito sobre o português e espanhol seria um pouco mais seguro, mas contra ele está o íntimo contato das línguas. Um outro étimo formado a partir do português e francês não tem segurança 
maior do que entre espanhol e português, pois, apesar do contato geográfico ser menor, a influência cultural do francês acabou transpondo fronteiras. Já um étimo formado a partir do português e romeno está mais próximo do seguro do que do hipotético, desde que não seja empréstimo recente. Obviamente, em todos esses casos, a semântica influencia muito o julgamento e não só línguas românicas devem ser levadas em conta (o basco, o albanês, o árabe, o inglês, por exemplo, são, muitas vezes, decisivos, pois importaram palavras do latim ou do romance).

Diz-se que o étimo é duvidoso quando é necessária a aplicação de leis fonéticas irregulares seja na base seja no sufixo a partir de um termo documentado. A questão semântica novamente não se coloca aqui.

Por outro lado, diz-se que o étimo é incerto quando, além de leis fonéticas irregulares, é preciso trabalhar com formas reconstruídas.

g) qual o grau de certeza do significado?

Para analisar melhor os casos, o significado é separado do significante, de modo que se verifica, também separadamente, se o significado do termo analisado é idêntico ao do étimo ou distinto dele. Dessa forma, o étimo sensibilis acima mencionado não tem o mesmo status do de caballarium, uma vez que o significado de sensibilis praticamente não mudou no português sensível, ao passo que caballarium e cavaleiro têm significados distintos (o termo caballarius em latim seria o "criador de cavalos (de má qualidade)" ou o "escudeiro"). No caso de palavras hipotéticas, duvidosas e incertas, podem-se também separar - do ponto de vista do significado - reconstruções transparentes (auto-explicativas, pela analisabilidade dos significados do radical e do sufixo) das obscuras (nas quais a analisabilidade requer explicações extra). A transparência, contudo, não noslivra dos casos especiais da etimologia popular (Viaro 2011). 
h) a palavra é analisável?

Dada uma palavra com um suposto sufixo, impõe-se a questão da analisabilidade. Há contudo, muitos casos especiais. Diz-se que uma palavra é analisável sob nossa ótica, se se trata do étimo esperado (no caso de -eiro, um vocábulo latino derivado em -arius/ arium). Entendemos que casos em que há alguma intermediação sejam considerados analisáveis. Por exemplo, as palavras estrangeiro e ligeiro vêm do francês, mas o sufixo francês -er dos seus respectivos étimos equivalem a -arius, portanto, são verbetes analisáveis. O mesmo ocorre quando o étimo imediato remeter à terminação -ero do castelhano ou a -aio do italiano, por exemplo.

Obviamente, surgem situações em que há certa dúvida. São comuns palavras com mais de um étimo dentre os quais um deles contém a condição de analisabilidade e os outros, não. Também alguma dúvida surge, vez ou outra, quando a origem do étimo é desconhecida. Todos esses casos merecem análise minuciosa e não uma tomada de decisão que exclua as demais hipóteses sem a verificação necessária.

Portanto, uma palavra não seria analisável:

- se contiver falsos sufixos, ou seja, possui terminação convergente, do tipo cadeira < cathedram, (não se trata de um composto em -ariam). Essas palavras, contudo, não são rechaçadas in limine, uma vez que reforçam o molde formal. Entram aqui não só palavras de origem latina, mas também germânica, indígena, africana, árabe, cuja terminação lembre a do sufixo. Obviamente as que, de fato, têm o sufixo estudado sobre uma raiz de origem germânica, indígena, africana ou árabe são analisáveis;

- se for composta por prefixação recente e se a palavra tiver significado facilmente decomponível por meio de uma paráfrase que reflita mera soma do prefixo+palavra restante (normalmente têm esse comportamento algumas palavras prefixadas com ante-, in- ou $i-$, des-, co-, sobre-, sob-, contra-, anti-, semi-). Por exemplo: insensivel, que facilmente se compõe de in+sensível por meio de uma paráfrase negativa ${ }^{14}$ :

$$
\text { in }[x=\text { "que não é } x " \text {; }
$$

\footnotetext{
${ }^{14}$ Apesar desse recorte, é óbvio que a palavra insensível tem uma história independente de sensível, porém entre nossos pressupostos norteadores está o de que palavras formadas por prefixação analisável sincronicamente sejam formadas depois das suas equivalentes não-prefixadas. Essa postura se revela frágil com palavras formadas com prefixação antiga, cuja decomposição não seja uma mera soma do prefixo+palavra restante: uma palavra como imposição, por não ser parafraseável, historicamente, como in+posição, é considerada analisável
} 
- se a palavra for composta a partir de outros radicais (gregos, latinos ou vernáculos), como hortifrutigranjeiro e agroecologia. Em alguns casos, sob uma ótica sincrônica é comum afirmar que um sufixo se mescla a um radical, como -meria, -logista ou -gráfico, formando uma nova unidade. Não é a nossa postura a respeito do assunto;

- se a palavra for composta por justaposição do tipo abóbora-de-carneiro. Este recorte só se justifica pela já explicada necessidade inicial de datação dos significados do sufixo. Obviamente palavras compostas por justaposição têm datação distinta de suas correspondentes simples (e muitas vezes o significado da palavra altera-se de forma substancial, como em pé-de-moleque), no entanto, isso é mais interessante para a Lexicologia do que para a Morfologia. São analisáveis, no entanto, palavras que acrescentaram sufixo sobre uma base justaposta (como em roupa-velheiro, a partir de roupa velha). Também ocorre o caso de o elemento que leva o sufixo não aparecer como palavra independente. Quando, por exemplo, não se encontra o termo isoladamente, também se deve analisar (por exemplo, no dicionário Houaiss não há o termo *gameleiro, embora haja dois verbetes compostos dele: sapo-gameleiro e bem-te-vi-gameleiro);

- palavras com variação ortográfica ou regional. Nesse caso, analisa-se a forma mais antiga e exclui(em)-se, por recorte, a(s) outra(s). No caso de as variantes não serem datadas, é preciso escolher uma delas, sob a qual as demais ficariam referidas, até maior esclarecimento. Por exemplo, se há camerlengo e camarlengo, analisa-se, num primeiro momento, apenas a primeira, por exemplo. O mesmo para variações de interfixos: cajaeiro cajazeira. Também casos de prótese ou aférese ocorrem: arruaceiro ruaceiro. São consideradas ambas analisáveis, contudo, as palavras que possuem sufixos distintos, ainda que sinônimas: sambeiro sambista. Tais palavras, aliás, são importantes para questões semânticas e de competição sufixal. Quando existirem sinônimos sem sufixo, obviamente só as formas sufixadas são consideradas analisáveis: bilimbeiro bilimbi, araçaeiro araçá-de-coroa, babeiro babadouro flor-de-babado. Também são analisáveis os casos de sinônimos com bases distintas: sinceiro salgueiro. Em cachamorreiro cachaporreiro caceteiro apenas duas formas são analisáveis: cachamorreiro, por exemplo, e caceteiro. A forma cachaporreirao é interpretada, num primeiro momento, como variante de cachamorreiro;

- reduplicações (do tipo cheira-cheira), que seguem a mesma regra dos compostos;

- homônimos gerados por simplificação de formas justapostas, que são tratados como homônimos normais. Dessa forma, bombardeiro tem dois homônimos. O primeiro é analisável, já o segundo remete a besouro-bombardeiro e é excluído provisoriamente, como dito acima. Ou seja, é apenas uma redução de uma justaposição. O mesmo com fuzileiro, que pode ser uma redução de fuzileiro naval;

- flexões (plurais de nomes e formas verbais diferentes do infinitivo de outras palavras analisáveis);

- palavras de origem obscura ou totalmente desconhecida.

Todos esses recortes e exclusões devem, contudo, ser feitos com cautela. Observando as etimologias fornecidas pelo Dicionário Houaiss, sobre a qual se retrocedem as datas a partir de outras fontes e corpora. Verifica-se que: 
- o verbete tombeiro não remete a nenhum verbete, não tem etimologia, mas, no corpo do texto, diz-se que é o mesmo que tambeiro: será, portanto, nessa palavra que a investigação deverá ser feita e, ao mesmo tempo, tombeiro será considerada sua variante;

- calaceiro não tem etimologia, mas o radical é reconhecido como o mesmo de calaçaria: desse modo, é considerado analisável;

- alperceiro remete a damasqueiro, portanto é analisável, mas albergeiro também remete a damasqueiro e entre os sinônimos há alpercheiro. Assim, albergeiro e alpercheiro podem ser considerados variantes de alperceiro;

- o verbete rinhadeiro remete a rinha, mas entre seus sinônimos estão rinhedeiro $e$ renhideiro, portanto, se apenas rinhadeiro é analisável, os demais serão variantes que precisam de esclarecimento (o mesmo ocorre com baageiro e bageiro: ambos remetem a guapuruvu, mas é claro que ambos são variantes da mesma forma: a escolha é arbitrária. Assim, baageiro será analisável e bageiro será variante);

- abaldeiro não remete a albardeiro, contudo é variante (informação que se obtém apenas no verbete desastrado);

- tafoneiro, além de remeter a atafoneiro, tem outras acepções que são bem distintas de atafoneiro, mesmo assim, apenas um é analisável (o mesmo ocorre entre flecheiro e frecheiro);

- tenreiro remete a novilho. Entre os sinônimos encontra-se terneiro;

- embondeiro viria do quimbundo mbondo e remete a baobá, mesmo assim, é analisável, pois é nome de árvore. O -eiro que se acrescenta à palavra do quimbundo é sem dúvida o sufixo (o mesmo com lagumeiro, que remete a olmo e tem origem obscura).

i) há outros elementos de formação?

Reconhecidos o radical e o sufixo, pode haver outros elementos presentes na formação da palavra (sufixos internos, prefixos, interfixos, vogais e consoantes de ligação, 
formas anômalas de sufixos). Trabalhando com o sufixo -dade, o pesquisador que depare com a palavra indecomponibilidade deve observar que ele também serve para os prefixos in-, de-, com- e -ível. O vocábulo verdoengo forma-se com o sufixo -engo, mas também com a vogal de ligação $o$. O étimo de sengo é *senicum, portanto, deve ser analisado juntamente com o sufixo -ico e não com o sufixo -engo.

j) qual a difusão da palavra?

É preciso verificar se o étimo gerou palavras em outras línguas além do português. Assim, se ocorre no português e galego, trata-se de uma palavra provavelmente formada no noroeste ibérico (ou apenas conservada ali); se ocorre no português, galego, espanhol e catalão, teve, contudo, uma difusão em toda Península Ibérica. Importante é verificar se há palavras cognatas que ocorrem nas outras línguas ibero-românicas (e no basco), com exceção do português e do galego. Tais línguas podem conservar dados e informações importantes para a reconstrução de sincronias pretéritas. Outras palavras têm distribuição em línguas românicas fora da Península Ibérica (por conservação ou por empréstimo) e até fora da área das línguas românicas (inglês, alemão, russo, japonês etc.). Nada deve ser descartado quando se investiga o étimo de uma palavra, mas os empréstimos precisam ser colocados dentro de uma cronologia a mais correta possível.

\section{I) qual a paráfrase da palavra?}

Importantíssimo para entender o significado do sufixo é traduzir a palavra na forma de uma paráfrase, inserindo nela o elemento presente no radical. Para evitarem-se deduções que possam conduzir a algum anacronismo, a paráfrase deve ser feita sobre o significado original da palavra, ainda que não seja o sentido mais corrente hoje em dia (às vezes de fato, não existe mais) e sobre a língua de origem, pois parafrasear em português palavras provenientes ou decalcadas de outras línguas seria falsear dados que pretender ser históricos. Portanto, a palavra deve ser parafraseada com o valor semântico do radical 
presente no momento de sua primeira abonação (ou por meio da reconstrução do sistema) em latim, francês etc. Palavras com radical opaco não são parafraseáveis, exceto se se conhece seu significado no momento de sua formação. Deve-se distinguir claramente o significado de toda a palavra (que sofre mudanças semânticas por metáfora, metonímia, ampliação, restrição etc.) do significado do sufixo (que nos interessa). Um verbete nãoparafraseável será, portanto, também não-analisável.

Entenda-se, nos casos seguintes, $\mathrm{X}$ como uma base lexical (sobretudo nominal) e $\mathrm{V}$ como uma base especificamente verbal (com ou sem preposições de sua regência). Evitam-se paráfrases com os termos "coisa", "relacionado com", "ato", "produto" e, sempre que preciso, utilizou-se o termo antecedente dos relativos quando o núcleo semântico da palavra fosse refletido pelo sufixo, como: "pessoa que V", "objeto que V", "que mora em X", "que vem de X", "que segue o ensinamento de X", "que pertence a X", "X de má qualidade", "grande quantidade de X", "que lembra um X", "próprio de X", "que $V$ muito", "que frequenta X", "que se ocupa com X", "que V", "que pensa como X". Esse é o primeiro passo. Contudo, ao agruparem-se as palavras, o significado do sufixo será uma abstração feita sobre essas paráfrases, de modo que o significado sufixal "que V (algo)" deve ser entendida como um deverbal, como, por exemplo lavadeira, em que algo = “roupa" não está expresso (e, por isso, está entre parênteses). Por outro lado, "que (V) X" quer dizer que o verbo se subentende e se trata de um denominal que faz as vezes de complemento do verbo reconstruído (é o caso, por exemplo, de pedreiro, em que $\mathrm{V}=$ "trabalhar com", não-expresso).

Assume-se, portanto, que cada verbete tem três tipos de significado: $o$ significado da base (quando for detectável), o significado do sufixo e, por fim, o significado da palavra toda. Interessa-nos particularmente o significado do sufixo, uma vez que o significado da palavra caracterizaria uma pesquisa de Lexicologia ou de Semântica Histórica e não de morfologia histórica. Um exemplo aparentemente esclarecedor é o caso de barbeiro, que tem a base barb- à qual se agrega o sufixo -eiro para criar um novo significado, portanto, significado do radical barb- ("conjunto de pêlos específico") independe do significado do sufixo -eiro, a saber, "(pessoa) que (V) X" (em que $V=$ "trabalha com") e, por fim, o 
significado da palavra barbeiro independe de ambos, embora seu primeiro significado fosse o resultado composicional da soma das duas partes. A existência desse terceiro significado independente (que justifica uma Lexicologia Histórica distinta de uma Morfologia Histórica) fica mais claro quando se verifica que sua transformação semântica independe dos significados do radical e do sufixo, assim, barbeiro passa a ser um "mau condutor" (por metonímia, extraído do significado básico agentivo, por um percurso mais ou menos assim: "que trabalha com barbas (usando navalha)" > "que corta com navalha" >> "que corta" >> "que corta os outros (no trânsito)" ou ainda o inseto hemíptero reduviídeo Triatoma infestans (Klug, 1894) transmissor do protozoário Trypanosoma cruzi (Chagas, 1909) "que trabalha com barbas" >> "que trabalha com rostos" > "(inseto) que pica os rostos". Observe-se que, nesses dois exemplos, reserva-se o símbolo >> para transformações semânticas, ao passo que, como tradicionalmente, o símbolo > indica apenas transformações no nível do significante.

Dessa forma, determina-se que:

- a palavra ciclista vem do francês cycliste. É preciso investigar como ela foi formada em francês e não criar uma paráfrase fantasiosa em português (por meio de formar primitivas como "bicicleta" ou "ciclo");

- a palavra tortura vem do latim: seria errôneo criar paráfrases sincronicamente a partir de torto. Deve-se investigar como foi sua criação em latim;

- a palavra poupança pode ter o significado de "nádegas", mas é significação secundária. Não entra na paráfrase pois é mudança do significado da palavra e não do sufixo.

- a palavra barraquista vem claramente de barraco ou de barraca, mas significa "aquele que negocia com seringueiros trocando a borracha extraída por gêneros alimentícios; dono dos maniçobais". É preciso uma investigação muito grande (e por vezes frustrante) para entender por quê, mas a falta de cautela pode conduzir a etimologias fantasiosas. Seria preferível julgá-las como não-parafraseáveis a fazer isso (o mesmo se pode dizer, por exemplo, de grileiro). 
m) qual o significado do sufixo?

Uma vez feita a paráfrase da palavra em questão e, posteriormente, estabelecidas as descrições parafrásticas mais abstratas, é possível agrupar inúmeros casos em categorias semânticas específicas. Optou-se por um código trilítere de tipo XXX, inspirado na classificação desenvolvida em Rio-Torto (1998:83-132), aplicável também para prefixos, como se pode ver. O código corresponde ao valor inicial do sufixo (não da palavra), independente do fato de a língua de formação ser o português ou não. No caso em que o valor inicial do sufixo for totalmente obscuro, marcou-se com três pontos de interrogação, isto é: ???. No caso de não haver alteração alguma entre base e palavra sufixada, usa-se 000. Também as palavras prefixadas se encaixam nessas classes, como se poderá observar:

\section{a) CLASSES RELACIONAIS}

1. PSS (< posse) para paráfrases "que tem X", "que possui X" (-ico, -ado, -ento, -oso, -il, -íaco, -udo);

2. GEN (< gentílico) para as paráfrases "que é originário/proveniente de X", (io, -íaco, -ão, -eiro, -eno, -eu, -ês, -ita, -aico, -eta, -ino, -oto, -ano, -ense);

3. SEM (< semelhança) para as paráfrases "que tem semelhanças com X", "que evoca X", "que tem propriedades de X" (-isco, -esco, -il, -engo);

4. TIP (< tipicidade) para as paráfrases "que é típico de $X^{\prime}$, "que é próprio de $X$ ", "que é característico de X", "que pertence a X", "situação em que há X", "situação em que se (V) X”, "que está na posição (de) X” (-esco, -ário, -al, ada, -ico, -ar, -eiro);

5. FIL (< filiação) para as paráfrases "que é adepto de X", "que é simpatizante de X", "que é partidário de X", "que crê que se deve V" (-ista, -ico, -ano);

6. ATV (< atividade) para a paráfrase "atividade associada a X", "ideologia associada a X", "filosofia associada a X", "sistema associado a X" (-ário, -eiro, -ão, -ista, -ia, -ismo); 
7. LOC (< local) para "local onde há X", "local em que se (V) X" (-al, -il, -eiro, aria);

8. VEG (< vegetal) para "planta que produz X" (-eiro);

9. DOE (< doença) para "doença associada a X" (-eiro);

10. QNT (< quantidade) para os coletivos e outros nomina quantitatis "conjunto de X", "quantidade de X" (-agem, -ada, -ame, -edo, -io, -aria, ugem) ;

11. QNL (< quantidade locativa) para "quantidade contida em X" (-ada, -eiro);

12. $\mathrm{RCP}(<$ recipiente) para "que contém X" (-eiro, -al, -ário);

13. EVN (< evento) para "evento localizado em X" (-ada);

14. TAX (< taxonomia) "táxon cujo gênero-tipo é X", "mineral associado a X", "substância química associada a X" (-áceo, -ídeo, -íneo, -ita, -ato, -eto, -ito, ico, -oso);

15. ESS (< nomina essendi) para abstratos formados a partir de paráfrase como "que é $X$ ", o fato de $(X)$ ser $X$ ", "propriedade de $(X)$ ser $X$ " ou para modais do tipo "que pode V", "que deve ser $X$ ", "que pode ser $X$ ", "que merece ser X" (-dade, -ência, -idão, -ice, -ude, -ez, -ado, -aria, -ato, -ato, -eira, -eza, -ia, -ismo, -ude, -ume, -ura, -vel)

16. $\operatorname{MOD}(<\operatorname{modo})$ para advérbios parafraseados como "de modo X" (-mente);

17. CPR (< comparação) vide valores avaliativos abaixo.

18. DIM (< dimensão) vide valores avaliativos abaixo.

b)CLASSES DE AÇÃO

1. AGE (< agentivo) para a paráfrase "pessoa que $V$ ", "pessoa que $V(X)$ " ou "pessoa que (V) X", "pessoa que gosta de (V) X", "pessoa que exerce atividade relacionada com X" , "pessoa que (V em) X" (-or, -eiro, -udo);

2. LCA (< local da ação) para a paráfrase "local onde se V" (-ório, -or, -nte, aria, -mento, -ouro); 
3. INS (< instrumento) para "instrumento (com) que (se) V", "instrumento (com) que (se) V (o X)" (-eiro) (-ouro, -ório);

4. MOV (< movimento) para nomina actionis (vide Rio Torto 1998: 119-120) que envolvam apenas o deslocamento de um ser ou se referem ao próprio deslocamento: "o fato de V", "ação de V", "processo de V" (-ada, -mento, ção, -agem);

5. TRS (< transitivo) para nomina actionis (id. ibid.) em que há apenas um agente e um paciente: "o fato de V", "ação de V", "processo de V" (-mento, -ção, -agem) ou "transformar (X) em X", "ação de transformar (X) em X", "ação de (V) X em", "ação de V X (em X)", "ação de causar X" (-ar, -izar, a...-ar, es-...ar, a-...-mento, em-...-ção, -ficar, -ecer, -ear); idem para golpes, tanto "golpe praticado com X", "golpe praticado em X" (-ada);

6. RES (< resultado) para nomina actionis (id. ibid.) em que há grande número de elementos envolvidos na ação ou nas ações: "o fato de V", "ação de V", "processo de V", " estado decorrente de V" (-ada, -mento, -ção, -agem, ança), mas também: "alimento preparado com X" (-ada) e "substância extraída de X" (-ina);

\section{c) CLASSES ORIENTACIONAIS}

1. INT (< interior) "V para dentro", "V para fora", "ação de V para dentro", "ação de V para fora" (im-, es-, intro-, extra-);

2. SUP (< superior) "V para cima", "V para baixo", "ação de V para cima", "ação de V para baixo" (super-, sub-);

3. FRN (< frontal) "que está em frente de X", "que está atrás de X", "que V para trás", "que V para frente" (pro-, re-, retro-)

4. LAT (<lateral) "que está ao lado de X" (a-);

5. ENT (< entre) "que está entre dois X", "que está no meio de vários X" (inter-, entre-) 
6. PRX (< proximidade) "V para perto", "V para longe", "ação de V para perto", "ação de V para longe" ( $a-$, dis-, com-, trans-);

\section{d) CLASSES LÓGICAS E QUANTITATIVAS}

1. NEG (< negação) para "que não é $X^{\prime \prime}(a-, i m-$, des-);

2. DES (< desfazer) para "deixar de V" ou "ação de deixar de V" (des-);

3. NUM (< número) para "(ação de) V outra vez" ou noções numerais exatas ou quantidades vaga (re-, multi-, pluri-, uni-, bi-, tri-, quadri-, mono-, tetra-, cento-, quilo-).

e) VALORES AVALIATIVOS:

Observou-se que, semanticamente, tais valores independem do significado nuclear do sufixo, como que formando um elemento à parte. Muitas vezes esse elemento se torna o único significado do sufixo. Para estes casos, portanto, acrescentam-se símbolos $>,<,+$ e - às siglas já apresentadas. São possíveis construções como $X X X<+$. Exemplos:

1. $X X X<$ para pejorativo (paráfrase: "X ruim": -inho, - $\tilde{o} o$ );

2. XXX> para ameliorativo (paráfrase "X bom")

3. CPR+ para superlativos (paráfrase: "muito X": -íssimo, -érrimo, -aço, -ão, super-, hiper-);

4. CPR- para pequena intensidade adjetival (paráfrase: "um pouco X": onho, -inho, -ito)

5. RES+ para ação intensa ou para ação frequente (paráfrases: "que V com frequência/ repetidamente"-itar, -inhar);

6. RES- para ações pouco intensas (-iscar);

7. QNT+ para grande quantidade (paráfrase: "que tem muito": -udo);

8. QNT- para o caso de nomina unitatis (Rio-Torto 1998:125) (-eiro); 
9. PSS+ para a paráfrase "que tem X grande/intenso" (-udo, -uço);

10. $\mathrm{PSS}<$ para a paráfrase "que tem $X$ ruim" (-udo, -ão, -inho);

11. PSS $>$ para a paráfrase "que tem $X$ bom" (-udo, -ão, -inho);

12. DIM+ para aumentativo (paráfrase "X grande": -aço, -ão, -arro, -orra, mega-, super-, ultra-, arqui-, supra-, hiper-);

13. DIM- para diminutivos (paráfrase "X pequeno": -inho, -ito, -ela, -iço, icho, -im, -éu, -ote, -ucho, -acho, -ola, -ete, mini-);

Alguns exemplos de aplicação:

- A palavra chuveiro, levando em consideração a "experiência do falante" (nome dado ao principal instrumento de trabalho postura sincrônica radical) é, ao mesmo tempo, analisável e não-parafraseável, por paradoxal que isso pareça ser: é possível, pelo método de comutação estruturalista, observar que há um sufixo e um radical (cf. chuv-inha, nevo-eiro), no entanto o falante nativo inventará inúmeras paráfrases improdutivas e inconsistentes com chuva para poder justificar seu radical (como "algo que parece X"). A verdade é que chuveiro significa apenas "chuva forte" e o significado de seu sufixo é "X forte" (XXX+), assim como nevoeiro, aguaceiro etc. A transformação semântica "chuva forte" >> "crivo do bocal por onde sai a água" >> "ducha" ocorre no significado da palavra e não no significado do sufixo, como o caso de barbeiro acima citado.

- A palavra jumento "certo mamífero equídeo" vem do latim jumentum "besta de carga", que, por sua vez vem do latim arcaixo iouxmenta (CIL I $\left.{ }^{2} 1\right)$, no qual, evidentemente há um sufixo associado ao radical jug-/ jung- "jugo, atrelar". Segundo Ernout \& Meillet 2001, remontaria a *youg-s-men-to-m, sendo o significado do sufixo "aquilo com que se $\mathrm{V}$ (o animal)". Por metonímia, o significado da palavra passou a significar o animal em que se atrela o jugo. 0 sentido inicial perdeu-se e o atual não interessa, pois o sufixo está irreconhecível. Neste caso será preenchido como ins. Se o sentido latino se mantivesse em português (o que não acontece), viria em maiúscula: INS. Se o sentido latino não se 
tivesse mantido, mas se tivesse desenvolvido um outro, por ex. LOC (seja em latim, seja em português), deveria vir indicado ins.LOC.

- Uma palavra como fumatório é ACT, mas o pesquisador verifica (em corpora ou pelo google) que seja também LOC, deverá vir da seguinte forma: ACT.loc. Aconselha-se que deve haver confirmação e não apenas "imaginar" que tenha esse sentido.

- Outros exemplos: feijoada RES, feijãozada QNT+, abrilada EVN, belenzada EVN, joelhada GLP, joelhada TRS, facada TRS, tacada TRS, baianada TIP ; vilório DIM<-; loucura ESS; amplificar TRS; banhista FIL, santista GEN.FIL, caçoísta AGE, marxista FIL; marxismo ATV; saleiro RCP; baciada QNL+; barbudo PSS+; barbona DIM+; beleza ESS; alistamento RES; boazuda ESS.000>; carrinho DIM-; formigueiro LOC.QNT+, laranjeira VEG, cegueira DOE, verdadeiro ESS, cafeeiro TIP, carroceiro ATV, fazendeiro ATV, caseiro TIP.ATV, faladeiro ATV+, fofoqueiro ATV+, tornozeleira INS "instrumento com que se (protege=V) o tornozelo $(=\mathrm{X})$ ", aguaceiro TIP.QNT+, besteira TIP.RES $<$, batucada RES+

Há inúmeras posturas com relação à depreensão dos significados dos sufixos. Há os que the negam qualquer significado. Outros imaginam que a comutação resolve o problema, o que é desmentido pelos interfixos, os quais não são de aceitação geral pois muitos entendem que os interfixos na verdade estão atrelados ou aos alomorfes dos sufixos ou formam parte do radical. Onde fica de fato -avi- em uma palavra como canavial? Junto com can- (alomorfe canav-) ou junto com -al (alomorfe -avial)? De qualquer forma, os interfixos perturbam a concepção didática de signo, uma vez que têm significante, mas não significado. O mesmo ocorre, por exemplo, com as vogais temáticas nas segmentações do tipo cant-a-r. Não nos esqueçamos de que algumas posturas teóricas não costumam distinguir sufixos e desinências. Também a transformação de classes promovida pelos sufixos é um problema e nem sempre se pode determinar com clareza se um sufixo, numa determinada palavra já construída, gerou um derivado deverbal ou denominal: é possível afirmar com certeza se alfinetada vem de alfinete ou de 
alfinetar? O próprio conceito de "derivação" goza de maior ou menor elasticidade, se incluirmos as derivações regressivas entre elas. Isso para não falarmos dos prefixos, que oscilam, segundo os autores, entre composição e derivação. O inventário de prefixos também depende de modelos assumidos pelos autores. A cada momento, os modelos precisam de soluções ad hoc para manterem-se, o que, sem dúvida, os fragilizam. Como já vimos, precisamos, na verdade, de definições e de uma base epistemológica segura e não de conviç̧ões e recortes que lancem formas excluídas de teoria que as explique (Hegenberg 1974).

Negar o elemento diacrônico pode gerar soluções contraditórias, uma vez que a migração de termos tradicionais da morfologia derivacional como "primitivo" e "derivado" não se coaduna a uma perspectiva sincrônica. Afirmações como a de Rocha (1998:189) “(a perspectiva diacrônica) não traz o menor proveito para a análise descritiva da língua", aparentemente, estão mais próximas do dogmatismo, segundo a terminologia corrente da Teoria do Conhecimento e da Filosofia da Ciência, mas sobre isso já discorremos suficientemente no capítulo 2 . Os testemunhos baseados em mais de um usuário da língua são, a nosso ver, mais científicos do que os formados pela declaração de gramaticalidade pautada na experiência particular do linguista-falante, que é falha na tentativa de detectar o significado do sufixo.

Paradoxalmente, os hiperagrupamentos dos significados dos sufixos (como considerar árvores como agentivos tanto quanto as profissões) se deve meramente a uma falta de método e ao desprestígio anacrônico da história, sobretudo nas correntes linguísticas após a década de 50 do século XX. Têm postura dedutiva e reducionista, nada tendo a ver com o falante nativo, que não hesitaria em definir uma mangueira como "uma árvore que produz manga" e não como "agentivo" da mesma forma que lavadeira.

Um sufixo como -eiro significando "árvore que produz $X$ " tem comportamento muito distinto de outro -eiro qualquer (profissão, coletivo, gentílico etc.) no tocante à sua produtividade. Além disso, esse derivado $\mathrm{X}]_{\text {eiro }}$ combina em gênero com sua base $\mathrm{X}$ : rosa $($ fem.) $\rightarrow$ roseira (fem.), abacate (masc.) $\rightarrow$ abacateiro (masc.), o que não ocorria nos derivados mais antigos. Essa diversidade comportamental do mesmo sufixo -eiro é 
recuperada à luz da polissemia (diacronicamente orientada) e não da homonímia, ainda que o -eiro de árvores aja, por exemplo, no tocante à sua produtividade, de forma semelhante ao sufixo -inho, o que não ocorre com os demais -eiro. Uma tipologia, qualquer que seja, não deve perder de vista o elemento diacrônico, sob pena de ter de criar um número excessivamente grande de soluções ad hoc para suas exceções.

Deve-se, além disso, repensar a denominação do conjunto heterogêneo dos "sufixos derivacionais", sustentável apenas por razões sintagmáticas: por definição, um sufixo é apenas qualquer elemento que vem depois do radical, mas isso parece subordinar o objeto de estudo da morfologia à sua composicionalidade. Desse modo, -eiro carrega o núcleo semântico da palavra derivada, ao passo que -inho não. São sintomas de que não se tratam de fenômenos idênticos. Na direção de soluções para problemas como esses, sem que sejam feitos recortes ou classificações demasiadamente rígidas na triagem dos dados, será possível que enxerguemos aspectos da linguagem em grande riqueza de detalhes, os quais a postura dedutiva acabam involuntariamente por esconder. 


\section{GÊNESE DO SUFIXO -EIRO: O SUFIXO -ARIUS (A, UM) NO SISTEMA LATINO}

Como já vimos, a transmissão de palavras ao longo do eixo diacrônico respeita uma série de pressupostos que, nem sempre são claramente explicitados, nos estudos linguísticos. Não é incomum a afirmação de que os sufixos -ário e -eiro do português são formas divergentes, provindas de um mesmo -ariu latino. Essa forma apocopada esconde muitos problemas, tornando-se uma solução fácil para algo que se requer investigação mais cuidadosa. De fato $o-m$ final do acusativo lexicogênico se apocopa em algum momento no latim vulgar, no entanto, isso só vale se entendermos o latim como um bloco monolítico, pressuposto que não deveria ocorrer em nenhum estudo diacrônico. Todo estudo linguístico que pretenda esclarecer lacunas históricas precisa prever a diversidade, por mais difícil que seja de ser localizada. O latim, por muito tempo, foi uma língua viva e suscetível de mudança e a homogeneidade do latim vulgar, tal como apregoada por alguns autores nada mais é que um dogma e, portanto, não tem outras exemplificações na realidade. Se o latim vulgar era suficientemente homogêneo para garantir a comunicação de alguém nascido na Hispânia, ao ir para a Dácia, por outro lado, o Império Romano foi longo o suficiente para promover alguma diferenciação regional. Além disso, as palavras cultas em -ário não vêm do acusativo, mas do nominativo, pois, sendo cultas, eram empregadas por quem conhecia minimamente as declinações (o mesmo se pode falar para formas medievais semicultas com -airo). O -arium acusativo lexicogênico vulgar gerará, por exemplo, apenas as formas em -eiro no português. Resumindo: formas em ário provêm dos nominativos (masculino -arius e neutro -arium) e formas em -eiro provêm de acusativos (masculino e neutro-arium). O mesmo se pode dizer das femininas: palavras terminadas em -ária têm tríplice origem: nominativo singular feminino -aria, nominativo/acusativo plural neutro -aria e formas geradas já em português e provindas do masculino -ário.

As formas em -ário provindas de masculinizações de -ária são raras, mas certamente também existem. A situação se complica ainda mais, como se verá abaixo, quando se consideram os casos provenientes de outras fontes que convergiram na 
formação do -arius latino (outros sufixos latinos foneticamente semelhantes ou ainda sufixos homônimos/ parônimos do grego).

No presente artigo, analisar-se-á o -arium neutro latino. Em outros artigos buscamos deslindar as diferenças semânticas do sufixo, mas havia até então uma grande lacuna no terminus a quo. Esse problema ainda não foi sanado, mas um passo é dado no momento. Partindo dos verbetes do Dictionnaire latin-français de E. Gaffiot (1934), obtiveram-se 236 palavras em -arium que serão abaixo analisadas.

Ver a língua exclusivamente como um sistema é vê-la sincronicamente, pois diacronicamente não se pode falar de sistema. Como já dissemos, a sincronia em si, não faz parte da essência do fenômeno língua, antes se trata de uma ilusão cognitiva gerada pela concordância de pessoas coetâneas que supõem decifrar igualmente o mesmo código em jogo. A língua que usam as pessoas não foi criada por elas, mas herdada e a contribuição individual normalmente é muito pequena, embora não nula. Também é possível entender a língua sincronicamente como algo artificial gerado por um método, de modo que somente assim possamos flagrá-la em seu funcionamento.

Ora, em qualquer modelo científico, o método deve diferenciar-se do objeto, pois é com a simplificação artificial promovida pelo método que se explica o objeto, caso contrário, os enunciados que o compõem devem ser submetidos a testes e, perante negativas (exceções), devem ser reformulados, criam-se elementos ad hoc, até, por fim, decretar-se sua morte (mas isso só ocorre quando um método mais poderoso completamente distinto surge). A unidade que faz vermos em diferentes sincronias $a$ mesma língua é, sem dúvida, convencional, como o são todos os signos linguísticos: o português medieval é bastante diferente do português atual e saltos qualitativos que permitam separar evoluções de uma língua a outra ou etapas da mesma língua normalmente não são claramente definidos e isso, talvez, não seja por falta de método, mas por uma impossibilidade gerada pelo objeto de estudo. Na biologia, por exemplo, uma espécie é um grupo de seres individuais que geram outros seres potencialmente reprodutíveis, mas se empregássemos inconvenientemente a mesma metáfora, substituindo a reprodução biológica pela comunicação, veríamos que entre a 
compreensão e a incompreensão há inúmeras gradações entre as línguas românicas ${ }^{15}$, de modo que o sistema se confunde com algo essencialmente político, que não se adapta a rígidos recortes como se tem feito na Linguística moderna. Não teorizamos, mas apenas constatamos que a história faz parte daquilo que chamamos língua e que a sincronia é algo que apenas nos possibilita enxergá-la, de modo que suas relações analógicas e suas regras gerativas se tornam bastante visíveis.

Além disso, a sincronia pressupõe uma variante da língua, senão nossas afirmações redundariam em falsas ou superestimar-se-ia seu escopo. Como a língua real é um todo heterogêneo de variantes diacrônicas e diatópicas, esse recorte muitas vezes também se faz necessário, no entanto, os resultados não visam à sua representação, mas, em última análise, à do próprio recorte. O mesmo problema se dá perante um corpus. As afirmações podem ser válidas para aquele corpus, mas a transcendência só será válida se, perante outros corpora, as afirmações se confirmarem. A indução obtida pelo corpus para adquirir status de modelo teórico dedutivo deve entender que a língua em si é diacrônica e variável. Só não o é, quando não se visa à explicação da língua em si, mas do método empregado. Nida (1949), por exemplo, considerava formas reconstruíveis pela sincronia tão boas quanto as pela diacronia, no caso de línguas indígenas: this does not mean that the reconstructed forms represent actual historical forms, but for the sake of our descriptive analysis these reconstructed forms may serve as the basic ones (p.16). No entanto, mesmo em línguas ágrafas, a reconstrução diacrônica é possível pelo contraste de línguas aparentadas, quando as há. Nida, porém, mais adiante, é ainda mais explícito

\footnotetext{
${ }^{15}$ A afirmação parece estranha, mas na verdade, entender uma palavra significa decodificar acertadamente seus impulsos auditivos ou visuais, não precisaremos dominar o sistema em que a palavra se insere: ao ouvirmos ou lermos o seguinte trecho em valáder, mesmo não sendo proficientes nessa língua, é possível termos êxito ao entender a sua mensagem.

Quists pronoms persunals emfatics vegnan dovrats generalmaing davo pronoms o substantivs per tils rinforzar. Las fuormas femininas vegnan eir dovradas per il masculin. II singular e'l plural han listessas fuormas (GANZONI 1983: 69).

Por outro lado, um texto formado com palavras extraídas de um dicionário de português nos pode garantir um êxito menor:

Os contubernáculos se locupletam vezeiramente de sodalícios equevos e chalaceiros, mormente cábulas, que, provectos a cote na verbiagem soez e batológica letificam coa sua joliz zangurriana e coa sua jucunda jiquipanga a mais mesta das circunjacências.

Dessa forma, o entendimento portanto prescinde do sistema e está envolvido num jogo de probabilidades e, portanto, poderia ser quantificado de maneira estatística.
} 
ao considerar a história como um elemento complicador para suas análises: knowledge of the history of a situation is not necessary in describing the present semantic value of the symbols (p. 153). Também a noção de significado é desproporcional com a de significante, sendo, dessa forma, inútil o paralelismo hjelmsleviano. Em acordo com nossa postura, Nida (1949), porém, afirma que meanings of recurring complex items are more than the sum total of the parts, for such a combination has its own history and acquires its own set of associations (p. 55). Nida postula que, em Morfologia, a soma das partes não é igual ao todo (que é explicável apenas historicamente). Separando o significado do radical, o significado do sufixo e o significado da palavra como três instâncias, observaremos que esses três significados são compreensíveis apenas na instância de uma teoria da cognição humana, que tem reaproximado a Psicologia da Linguística nos últimos anos.

Sendo o conceito de sistema temporariamente suspenso em nossa análise, a relação interlinguística será vista de maneira natural. No âmbito lexicológico, não há fronteiras sistêmicas para as palavras, como se verifica no fenômeno do estrangeirismo, uma vez que a transmissão das palavras equivale mutatis mutandis à transmissão epidemiológica. Estudar o sufixo -eiro passa a ser, portanto, não só o seu desenvolvimento desde o latim, mas a sua poligênese e sua difusão entre as línguas, tanto do latim para outras línguas românicas quanto do português para outras línguas românicas (ou não-românicas) e vice versa. Estudar a palavra como um fenômeno único, alicerçada não num sistema, mas num ordenamento natural de mudanças semânticas é o que resume o nosso método.

Dentro da diacronia do sufixo -arium retiramos quatro momentos sincrônicos, com a finalidade de definir melhor a cronologia das mudanças.

- Latim-1, trata-se de um período de dois séculos (III e II a.C.) que compreende os nascimentos de alguns autores como Plauto (254-184 a.C.), Catão (234-149 a.C.), Lucílio (160c103 a.C.), Asélio (158-91 a.C.) e Varrão (116-27 a.C).

- Latim-2 equivale ao período clássico (I a.C.-I d.C.): Cícero (106-43 a.C.), Labério (105-43 a.C.), César (100-44 a.C.), Catulo (84-54 a.C.), Vitrúvio (c80-c15 a.C.), Nóvio (fl c30a.C.), Virgílio (70-19 a.C.), Horácio (65-8 a.C.), Higino (64 a.C.-17d.C.), Sêneca (c54 a.C-c39d.C.); Tito Lívio (59 a.C-17d.C.), Múcio Cévola (?), Ovídio (43 a.C.-c17d.C.), Fedro (15 a.C-50d.C.), Sêneca, o moço (4 a.C.-65 d.C.), Columela (4-70), Plínio (23-79); Celso (c25-c50), Petrônio (c27-66), Frontino (40-103), Marcial (41-104), Juvenal (42-?), Estácio (c45-c96), Tácito (c56-c117), Plínio, o moço (61-c112), Suetônio (c75-130) e as notas tironianas (sob Cícero). 
- Latim-3 abarca o período tardio (II d.C.-IV d.C.) com Cervídio Cévola (séc. II), Apuleio (c125c180), Aulo Gélio (125-180), Gaio (130-180), Tertuliano (160-220), Quintiliano (c35-c100), Ulpiano (c170-228), Comodiano (fl 250), Cipriano (?-258), Censorino (séc III), Paládio (séc. IV), Lâmpridas (séc. IV), Carísio (séc. IV), Teodoro Prisciano (séc. IV), Donato (séc.IV), Diomedes (séc. IV), Plínio Valeriano (séc. IV); Ausônio (c310-395), Amiano Marcelino (c325-d391) e as digestas de Cévola (sob Marco Aurélio).

- Latim-4 compreende sobretudo o período cristão dos séculos IV a VIII com: Santo Ambrósio (c337-397), Símaco (c340-c402), Rufino (c345-410), São Jerônimo (c347-420), Santo Agostinho (354-430), Sulpício Severo (c363-c425), Apício (séc IV-V); Vegécio (séc. IV-V), Marciano Capela (séc. V), Célio Aureliano (séc. V), Sérvio ( $f(420)$, Gelásio (?-496), Genádio (?496), Cassiodoro (c485-c585), Boécio (c480-c524), Fulgêncio (séc. V-VI), Prisciano de Cesareia (fl 500), Gregório de Tours (538-594), Santo Isidoro de Sevilha (c560-c636), Paulo de Festo (c720-799?) além da Itala, da Vulgata, do Codex Theodosianus, do Glossarium Isidori, da Digesta Justinianum e do Codex Justinianus.

Por entre todos esses períodos estão os textos das Inscriptiones, do Glossarium Graeco-Latinum, do Corpus Glossariorum Latinorum, do Corpus Inscriptionum Latinarum (CIL), da Scholia ad Juvenalem, dos Gromatici Veteres e do Glossarium Cyrillianum. Uma pesquisa mais aprofundada, sobretudo na época denominada latim-4 será de grande importância para a reconstrução aqui proposta.

Se utlizarmos o dicionário Gaffiot como corpus do latim clássico (uma vez que, teoricamente, deveria abarcar o período de quase um milênio, entre Lei das Doze Tábuas, até a Digesta, embora na prática extrapole um pouco), observaremos que o conjunto de palavras terminadas em -arium é bastante heterogêneo com relação à sua origem. O que se afirma aqui, para esse nosso recorte, é válido, aparentemente, para todos os sufixos do latim ou do português.

A forma marium é um genitivo plural (mare) e, portanto, é uma coincidência. Tais casos devem ser retirados do corpus, uma vez que só fazem sentido nos complexos estudos de simbolismo linguístico. O número abaixa para 235 palavras.

Nomes próprios também têm status especial: Apiarium, Barium, Lararium, Parium, Tyndarium, Vivarium, Vocarium. Com exceção do primeiro, que também é um nome comum, todos os demais são excluídos. O número se reduz para 229. Respeitamos, dessa forma, os pressupostos dos estudos ontológicos que distinguem o nome próprio do comum, dada a unicidade referencial, fato incomum à maioria dos signos linguísticos. $\mathrm{O}$ nome próprio, rigorosamente falando, é um tipo de signo que não deve ser submetido aos 
mesmos modelos dos demais signos linguísticos (assim como, por outro motivo, estão as interjeições), como ocorre na Onomástica (e suas divisões clássicas: Toponímia e Antroponímia). Isso fica evidente quando se estudam as etimologias dessas palavras. Quando não remonta a substratos obscuros, a neologia, nessas palavras, é particularmente mais visível e, não raro, há rompimentos evidentes em sua fonologia.

Todos os demais casos de exclusão são bem mais complexos. Para além da polissemia do sufixo, há o fenômeno da homonímia ou homofonia, no caso do sufixo arium, causada por semelhança com outros sufixos com -a+consoante líquida. Provavelmente, o sufixo -arius faz parte da mesma complexa rede sufixal que gerou -aris, uma vez que encontramos - paralelamente a uma arcaica coquinaris - a clássica coquinarius, mas essas relações nem sempre são claras e, muitas vezes, formas com arius/a/um ocorrem posteriormente a formas em -ar/-al.

(a) -ar, -are; -al, -ale >-arium

Dessa forma, há um -arium que provém de -ar, sufixo de origem distinta. Há sete casos (pulvinarium, lacunarium, gemellarium, lupanarium, boletarium, laquearium, ansarium). Também há o que provém de -are (dois casos: collarium, altarium) e de -ale (dois casos: mulctrarium, ponderarium). É sabido que, em determinadas sincronias, há distribuição complementar entre os sufixos $-a l(e)$ e $-\operatorname{ar}(e)$, sendo o segundo obtido por dissimilação, evitando-se duas laterais (menstru-alis, mas: Iun-aris, sol-aris) ${ }^{16}$. De qualquer forma, as mesmas paráfrases obtidas com -arium não são possíveis nesses casos e, se pensarmos, que foi um fenômeno comum no latim vulgar, talvez tenha contribuído muito para a valorização do significado da palavra, em detrimento do significado do sufixo, dando azo a muitas construções obscuras que aparecerão mais tarde, como se verá. Casos de oscilação: torcular (latim-2)/ torcularium (latim-1), pulmentaris (latim-2)/ pulmentarium (latim-1); alveare (latim-2)/ alvearium (latim-3); nubilare (inscr.)/

\footnotetext{
${ }^{16}$ O motivo da convergência sufixal entre esses sufixos e-arium é obscura e mereceria um estudo futuro mais aprofundado. Podem envolver inclusive erros de copistas. A distribuição e a pequena ocorrência não facilitam a compreensão do fenômeno.
} 
nubilarium (latim-1); aquimanile/ aquiminale/ aquæmanale/ aquimanarium/ aquimanarium (latim-4), bacarium "copo" (Gloss)/ bacar (latim-4).

(b) -ápıov>-arium

Outro elemento que contribuiu para o obscurecimento da função de -arium foi a equivalência, motivada por semelhança fonética, de sufixos e terminações gregas. $O$ mais

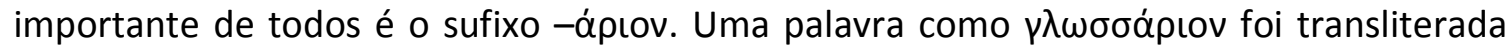
como glos(s)arium "glossário". Como se verá, isso deu azo a outras formações e a um

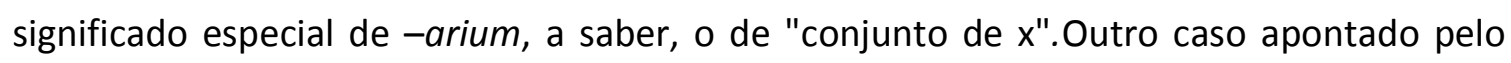

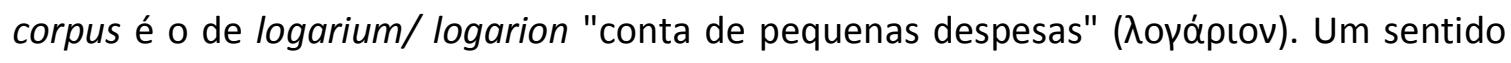
homônimo desse sufixo é o de diminutivo: bolarium/ volarium "carocinho (na pintura)"

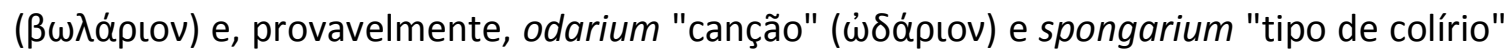
(бторүápıov).

É preciso também atentar para uma comum mudança de gênero e/ou número nas palavras latinas:

(a) -arius $\rightarrow$-arium

Algumas palavras se relacionam a substantivos homônimos de gênero gramatical distinto. Dessa forma, commentarium ou commentarius aparecem como sinônimos em Cícero. Como a maior parte das palavras em -arium, referem-se a coisas, tais formas terminadas em -arius parecem absolutamente excepcionais (colocando-os, muitas vezes, sob suspeição de serem casos de erros à luz da ecdótica) e somente as formas em -arium são consideradas. Chama à atenção o fato de que a forma masculina apiarius é o apicultor enquanto o neutro apiarium é a colmeia, mostrando uma relação ainda visível entre o elemento animado e o masculino. As formas neutras em -arium dessa forma, jamais indicam agentes, como ocorre com as formas masculinas em -arius. 
(b) -aria $\rightarrow$-arium

Uma forma feminina singular terminada em - $a$ podia ser interpretada como um neutro plural em $-a$ (produzindo, assim, uma ideia coletiva) e gerar analogicamente um substantivo neutro em -um no singular. Dessa forma, em latim-2, arenaria parece subentender um substantivo feminino como via, mas concorria com o substantivo neutro iter, o que justifica o sinônimo arenarium, usado no mesmo período. A função substantivizadora de -arium (maior do que a de -aria), cada vez mais produtiva, também auxilia os câmbios de gênero. Alternando entre -arium e -aria encontram-se: granarium/ granaria (latim-1); donarium/ donaria (latim-2), cetarium/ cetaria (latim-2); tabularium/ tabularia (latim-2); compendiarium/ compendiaria (latim-2); scrutarium/ scrutaria.

(c) -orium $\rightarrow$-arium

Valores locativos de -arium podem convergir com de outro sufixo, -orium, de diferente origem, fato que se torna bastante evidente perante a (rara) oscilação dos dois, como ocorre em unctorium/ unctuarium (latim-2).

(d) -ápos >-*arus $\rightarrow$-arium

A terminação -ápos tornada neutra (siparum) convergiu para uma forma siparium.

(e) -apsi $\alpha>-*$ aria $\rightarrow$-arium

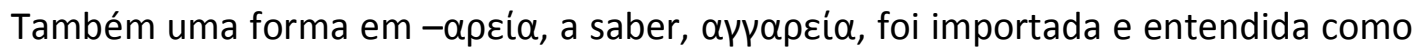
-aria feminino (angaria) ou como plural, donde se deduziu um -arium singular (angarium). Apesar das palavras acima apresentadas disporem de uma terminação homófona, a saber, -arium que contribui em muito para a complexificação do significado do sufixo, não 
devem ser incluídas no corpus de análise deste capítulo, que passa a ter, assim, 209 palavras.

Algumas palavras, todavia, são o que nos resta da fonte de alguns sentidos de palavras criadas com essas terminações convergentes, as quais não são claros empréstimos como as acima apresentadas. Uma palavra como stillarium "pequena gota" (Sêneca, o moço, latim-2), porém, proveniente de stilla "gota" é demonstração de que o significado diminutivo do sufixo grego se encontra já produtivo no período clássico. $\mathrm{O}$ mesmo se passa com corollarium "pequena coroa" (Plínio, latim-2), lardarium "pedaço de toucinho" (Not. Tiron., latim-2), olerarium "legumezinho" (Gloss.). Talvez também seja diminutivo o verbete ovarium (Inscr.), embora Gaffiot o considere sinônimo de ovum. 0 fato de o diminutivo derivar, nas mais variadas línguas, um significado valorativo positivo (como em filhinho) ou negativo (como em mulherzinha) e, subsequentemente, esvaziar-se semanticamente de modo completo (como abonam vários étimos do Appendix Probi e palavras no português como sozinho), também é uma possibilidade. Pelo menos uma forma antiga talvez seja a primeira prova de um esvaziamento completo do sufixo: alvarium (Varrão, latim-1; alvearium latim-3), que equivale a alvus (latim-2) ou se ligue, mais tardiamente, a alveare (latim-2). O valor diminutivo desse -arium e seu derivado esvaziado é paralelo. Alguns casos de valorativos: (p)tisanarium "tisana de cevada" $(\leftarrow$ ptisana "cevada) (Horácio, latim-2), cibarium "farinha grosseira" $(\leftarrow$ cibus "alimento") (Sêneca, o moço, latim-2), pap(p)arium "papinha" (Sêneca, latim-2) < pappa "comida", moretarium "iguaria feita de ervas, queijo, alho e vinho" (=moretum) (Donato, latim-3), dulciarium "guloseima, confeitaria" ( $\leftarrow$ dulcium "bolo") (Gloss). Outros possíveis casos de significados diminutivos esvaziados: velarium "cortina do teatro" $\quad \leftarrow$ velum "vela do navio") (Juvenal, latim-2); cellarium "dispensa" (Cervídio Cévola, latim-3), dracontarium "colar ou coroa em forma de dragão" (Tertuliano, latim-3), cerotarium "ceroto, cerol" (=cerotum) (Teodoro Prisciano, latim-3); thesaurarium "tesouro" (Cassiodoro, latim-4), subgrundarium "alpendre para uma sepultura de uma criancinha" $(\leftarrow$ subgrunda "cimalha") (Fulgêncio, latim-4), diplomarium "diploma" (CIL). 
No entanto, é justo dizer, que o -arium ${ }^{1}$ legitimamente latino e um -arium ${ }^{2}$ diminutivo proveniente do grego -ápıov formavam um todo coeso que provoca a ilusão sincrônica da polissemia (tanto nos linguistas atuais quanto, muito provavelmente, nos falantes da época), embora, cientificamente falando, sejam apenas homônimos. Outros sentidos são derivados e procedem do sentido básico: $-a_{\text {rium }}^{2}$ pode ser representado por uma linha paralela ao lado da árvore - mais produtiva - formada por-arium ${ }^{1}$.

Por outro lado, o -ápıov de glossarium, a saber, "Y que tem muitos $\mathrm{X}$, conjunto de X" formou um subconjunto especial de palavras: commentarium (Cícero, latim-2), sendo a base o particípio substantivizado commenta "coisas criadas, inventadas, imaginadas, feitas" (cf. sinônimo masculino commentarius também em Cícero, latim-2). O mesmo significado de conjunto ocorre em inventarium "inventário i.e, conjunto das coisas encontradas (inventum)" (Ulpiano, latim-3), itinerarium "mapa, i.e. conjunto de caminhos (iter)" (Amiano Marcelino, latim-3), eclogarium "recolha de pequenas peças (ecloga)" (Ausônio, latim-4), trigarium "conjunto de três coisas" (Capela, latim-4, com interessante interfixo -g-), hymnarium "hinário" (Genádio, latim-4), vitrarium "vidraria" (Gloss), herbarium "obra de botânica" (Cassiodoro, latim-4). Esse é outro sentido básico paralelo, a saber-arium ${ }^{3}$. Um sentido derivado desse é bellarium "equipamentos de guerra" (Paulo de Festo, latim-4), a saber, "conjunto de $Y$ de $X "$.

Um curioso -arium ${ }^{4}$ derivado do empréstimo spongarium, acima mencionado, poderia ser uma fonte para cycnarium "tipo de colírio" $(\leftarrow$ cycnus "cisne') (CIL), se essa palavra não é, ela mesma, outro empréstimo.

Já a forma coquinarius (que gerou a palavra cozinheiro em português pelo acusativo do latim vulgar) era um adjetivo que significava simplesmente "que é da cozinha", "que é relativo à cozinha", ou na sua forma abstrata, "que é de X" ou "que é relativo a X" (sendo $\mathrm{X}$ a base), que é seu significado básico. Como adjetivo, podia flexionar-se em masculino, feminino ou neutro, singular ou plural ou em quaisquer casos, gerando, em teoria, trinta e seis flexões distintas. O significado do sintagma nominal, contudo, conduziu a uma simplificação por eliminação do substantivo (tido contextualmente como óbvio) que o transformou de adjetivos em substantivos. Esses substantivos se mostram bastante 
peculiares em muitas simplificações, formando, frequentemente, o que chamamos de galhos isolados numa suposta árvore genealógica. Alguns desses galhos, porém, possivelmente devido à frequência de uso de determinadas palavras, serviram de moldes para outros neologismos. Esses neologismos, por sua vez, se devem a uma reinterpretação do significado da palavra de modo que uma parte desse significado foi atribuído ao significado do sufixo, mudando assim, sua carga semântica de tal modo que se torna detectável num estudo diacrônico. Por exemplo, coquinarius desligado de seu núcleo sintagmático subentendido (vir, servus), literalmente passa a significar "o homem/servo/escravo da cozinha", o qual se reinterpretou automaticamente como "o homem que trabalha na cozinha". Posteriormente, abstraiu-se um significado produtivo e gerador de neologismos "homem que trabalha em X" e, após novas abstrações ainda mais genéricas, "homem que $V$ em $X "$ e "Y que $V$ em X", sendo $X$ a base; $V$, um verbo apenas interpretável pelo conhecimento sincrônico compartilhado da língua entre os falantes e $Y$, o gênero (no sentido aristotélico) ou hiperônimo (na terminologia corrente da linguística) a que a palavra pertence.

A afirmação corrente de que os sufixos não têm significado advém, na verdade, de um lado, de um significado abstrato e, de outro, de uma interpretação do que julgamos ser a própria complexidade de seu significado, uma vez que não os entendemos como um conjunto de signos monossêmicos homônimos, mas como unidades polissêmicas que envolvem significados produtivos, significados não mais produtivos, significados advindos de convergência formal e galhos isolados.

Apenas duas palavras no corpus estudado ainda estão ligadas intimamente à sua forma adjetiva original: ruderarium cribrum "peneira de cascalho (rudus)" (latim-3) e capitarium aes, que se parafraseia no próprio dicionário como quod capi potest (latim-4). Um pouco mais distanciadas, estão pulmentarium "comida que serve de guisado" (Catão, latim-1); diarium "relação diária" (Asélio, latim-1); mil(I)iarium "pedra que marca uma milha" (Varrão, latim-1); extermentarium "roupa que se usa na massagem" (Varrão, latim1), de um substantivo *extermentum, provindo do verbo extero "fazer sair, esfregando"; arenarium "caminho de areia" (Vitrúvio, latim-2: na mesma sincronia, também se diz no 
feminino arenaria), nefarium "crime abominável" (substantivação neutra de nefarius "abominável" $\leftarrow$ nefas "contrário às leis, sacrilégio)" (Tito Lívio, latim-2); salarium "porção de sal" (Plínio, latim-2) e petrarium "caminho de pedra" (Cipriano, latim-4) e, provavelmente, tertiarium "um terço" (Catão, latim-1), deadjetival de tertius "terceiro".

A escassez desse sentido básico, porém, não significa que sempre seja o que mais rapidamente deixa de existir. Da mesma forma, qualquer sentido derivado não deixa simplesmente de existir só porque se gerou uma especialização mais nova. Uma "árvore genealógica de sentidos" deve, portanto, ser entendida tridimensionalmente, mais como uma cordilheira, a qual, vista de cima, forma cadeias de montanhas, a despeito de possuírem pontos mais altos que outras. Os pontos altos seriam a prolificidade de cada significado, embora ramificações com pouca prolificidade possam sobrepujar outros, por um efeito gerado pela alta frequência de uso de alguns participantes.

A prolificidade e a frequência são dois fatores correlacionados que permitem a neologia, mas só adquirem um valor gerativo tão intenso e previsível quanto na sintaxe quando não há concorrências com outros sufixos. Insistir em ver quaisquer sufixos ou quaisquer sentidos de sufixos como disponíveis de geratividade, sem levar em conta a história e sem diferenciar as peculiares dos sentidos que compõem seu significado, equivale a aceitar listas de exceções, como na Gramática Tradicional, bem como princípios estruturalistas de segmentação pouco compatíveis com os pressupostos teóricos de uma Gramática Gerativa.

Como visto acima, - arium $^{1}$ é simplesmente a forma do neutro de adjetivos denominais latinos em -arius. Já o sentido básico dos substantivos em -arium ${ }^{1}$ revela, desde cedo, alguns núcleos claramente definidos. Um dos mais antigos reflete um "local onde se V X": gallinarium, encontrado já em Plauto (latim-1), por exemplo, é o étimo da palavra galinheiro em português. O substantivo neutro com o qual o adjetivo concordava em gênero e que foi subentendido promoveu a translação do adjetivo gallinarius "de galinha" para o substantivo gallinarium "local onde estão/ se criam/ se guardam as galinhas". O verbo, por não estar explícito, precisa ser decifrado pelo ouvinte e, por isso, não são raros os casos de múltipla interpretação. Nessa translação, o sufixo herdou o 
núcleo semântico do substantivo subentendido (e perdido), promovendo, com essa incorporação, o contrário do fenômeno conhecido como gramaticalização. Obviamente, a primeira palavra que promoveu essa translação e essa transformação de sentido é impossível de ser localizada.

Dispomos, porém, apenas de indícios de como pode ter sido essas transformações de sentido, uma vez que o corpus estudado não é um dicionário etimológico e não se preocupa exatamente com a primeira ocorrência da palavra, mas as datas nele apresentadas podem servir de terminus a quo.

Da mesma forma que gallinarium (Plauto, latim-1), temos: coc(h)learium "local onde se criam caracóis (cochlea)", columbarium "local para criação de pombas (columba)"; glirarium "abrigo para arganazes (glis)", turdarium "lugar de criação de tordos (turdus)" (Varrão, latim-1); aviarium "local onde se guardam aves" (Cícero, latim-2), apiarium "colmeia" (Aulo-Gélio, latim-3) para $\mathrm{X}$ referentes a animais (nesse caso, $\mathrm{V}$ pode ser interpretado como "criar"); cetarium "viveiro de peixes (cetus)" (Horácio), suarium "chiqueiro (广sus)" (Gloss), viverrarium "lugar onde se criam furões (viverra)" (Glos), porcinarium "chiqueiro" (Glos.), este último de porcinus, portanto, ou é deadjetival ou testemunha indiretamente um porcinus substantivo do latim vulgar.

Para plantas, há a interpretação $V=$ "cultivar" em: seminarium "local onde se plantam sementes (semen)" (Catão, latim-1), pomarium "pomar (de pomum)", vir(i)d(i)arium "horta" (do adjetivo substantivado viridia "verdura") (Cícero, latim-2), rosarium "campo de rosas" (Virgílio, latim-2), plantarium "viveiro de plantas", ulmarium "plantação de ulmos (ulmus)" (Plínio, latim-2), cucumerarium "plantação de pepino" (S. Jerônimo, latim-4), malarium "pomar $(\leftarrow$ mala)". A palavra ulmarium também pode ser representada por outro sufixo: ulmetum (gloss.), que equivale ao sufixo -edo (cf. arvoredo). $\mathrm{Na}$ forma verdiarium, encontrada nas inscrições, transparecem-se transformações fonéticas do latim vulgar ( $\breve{l}>$ e, síncope da pretônica).

Com V = vender, há pomarium "local onde se vendem frutas (pomum)" (Plínio, latim2). Esse sentido se aproxima também do de -aria (cf. calcearia "sapataria", furnaria "padaria"). O mesmo vale, como reforços tardios, como para hastarium 
"venda"(Tertuliano, latim-3), com cujo sufixo se reforça o significado já contido em hasta "venda'. Outros exemplos: scrutarium "antiquário, adelo" ( $\leftarrow$ scruta "velharias") (Gloss); seplasarium "perfumaria" ( $\leftarrow$ seplasium "tipo de perfume") (Gloss).

Se, porém, V = guardar e as coisas guardadas são objetos, temos: ærarium "local onde se depositam coisas de bronze (æs) ", tabularium "arquivo público $(\leftarrow$ tabula)" (Cícero, latim-2), encautarium "arquivo público $(\leftarrow$ encautum)" (Cod. Theod., latim-4). Nesse sentido, há uma convergência com o significado de -arium ${ }^{3}$ "conjunto de X" e com a forma feminina (ou neutra plural) -aria. Outros exemplos: armamentarium "local onde se guardam armas"(Cícero,latim-2), farrarium "celeiro' $(\leftarrow$ far "farinha") (Vitrúvio, latim-2), doliarium "celeiro se guarda o vinho em vasos (dolium)" (Gaio, latim-3), cinerarium "sepultura, i.e. lugar onde se guardam as cinzas (cinis)" (CIL); farinarium "celeiro" (Gloss) $(\leftarrow$ farina $)$.

Se $V$ é entendido no sentido abstrato máximo, de "haver, encontrar-se", as paráfrases se tornam mais abertas. Por exemplo, com bases referentes a animais, também se pode interpretar V tanto como "haver" quanto como "caçar": vivarium "local de caça" $(\leftarrow$ vivus "ser vivo, animal" ) (Sêneca, o moço, latim-2). Também se pode dizer o mesmo para mellarium "colmeia $(\leftarrow$ mel)" (Varrão, latim-1), ostrearium ou ostriarium "local onde há ostras/ onde se coletam as ostras" (Plínio, latim-2). Outros exemplos: aquarium (Catão, latim-1) "onde há água", trigarium "campo de corrida de trigas" (Plínio, latim-2), emissarium "escoadouro", i.e. "local onde estão as coisas jogadas fora (emissa)" (Cícero, latim-2); sacrarium "local onde há coisas sagradas (sacra)" (Cícero, latim-2); clipeolarium "depósito de pequenos escudos (clipeolum)" (Notas Tiron., latim-2); immissarium "reservatório", i.e. "local onde as águas são jogadas dentro" (†immissa) (Vitrúvio, latim-2), cloacarium "local onde há esgoto" ( $\leftarrow$ cloaca) (Ulpiano, latim-3), roborarium "paliçada" (டrobur "carvalho") (Vulgata, latim-4), scænarium "local da cena (scæna)" (CIL), subseliarium "local onde ficam os bancos (subselia) dos magistrados no teatro"(CIL), obrendarium "sepultura" $(\leftarrow$ obrendarius "relativo à inumação" $\leftarrow$ *obruendarius $\leftarrow$ obruendus $\leftarrow$ obruo "recobrir, esconder") (Inscr); ollarium "nicho de sepultura" $(\leftarrow$ olla) "urna funerária" (Inscr); sacomarium "peso público" ( $\leftarrow$ sacoma "contrapeso") (Inscr) . 
Como se pode observar, a noção de "local" é ,portanto, bastante ampla, podendo referir-se tanto a ambientes naturais quanto a construções feitas pelo homem. Também cal(i)darium "forno, caldeira, caldeirão" (Sêneca, o moço, latim-2), cuja base calidum "calor" é parafraseável como "local/ construção onde se produz/ há calor" ou em viscarium "armadilha, i.e. laço/local onde se usa visco (viscum)" (Sto. Agostinho, latim-4). Aparentemente, o sufixo em questão não distingue essas duas possibilidades. Outros exemplos: granarium "local onde se guardam grãos" (Plauto, latim-1), saginarium "local onde se faz a engorda (sagina) dos animais" (Varrão, latim-1); donarium "local onde se depositam as oferendas (donum)" (Virgílio, latim-2)., vigil(i)arium "guarita, i.e. lugar onde se faz a guarda (vigilia)" (Sêneca, o moço, latim-2), , spoliarium "local onde se colocam os despojos dos animais (spolium)" (Sêneca, o moço, latim-2, usado com sentido da palavra alterado "lugar onde se colocam os corpos dos gladiadores"), fumarium "quarto onde há fumaça (fumus), i.e. para defumar" (Columela, latim-2), palearium "local onde se guarda a palha" (Columela, latim-2), sanctuarium "local onde ficam as coisas sagradas" (Plínio, latim-2, com uma vogal temática - $u-$ : o significado geral dessa palavra mudou-se no período clássico) e pilarium "local onde se colocam urnas funerárias" (૯pila?) (Inscr).

Desses casos, derivou-se certamente uma nova paráfrase complexa e pouco produtiva: "local onde se $\mathrm{V} Y$ de $\mathrm{X}$ ", da qual participa nubilarium "local onde se guarda/ protege o trigo da chuva $(\leftarrow$ nubilum)" (Varrão, latim-1). A forma frig(i)darium (Lucílio, latim-1) "local frio", deve ser entendido como "lugar onde há frio", permitindo tanto a leitura "Y onde há X" (frigidum, denominal) quanto "Y que é/está X" (frigidus, deadjetival): ambas leituras, porém, estão bem próximas ainda do valor básico, assim como solarium "relógio solar" (Plauto, latim-1), æstuarium "local de grande calor (æstus)" (César, latim-2), tepidarium "sala de banhos quentes" $(\leftarrow$ tepidus, portanto, claramente deadjetival) (Vitrúvio, latim-2), summarium "sumário, abreviação" $(\leftarrow$ summus "superfície") (Sêneca, o moço, latim-2).

Outro caso semelhante é laniarium "açougue" (Varrão, latim-1), cujo significado do sufixo concorre com -aria, i.e, "local do açougueiro (lanius)" e pode ser entendido 
também pelo sentido básico e, provavelmente. É o caso de custodiarium "guarita" (Tertuliano, latim-3), onde fica o guarda (custos).

Mais complexo, pois não dispormos da base, mas certamente do mesmo grupo é colliviarium "canal" (Vitrúvio), que provém de uma base *collivium (< *con-lav-ium). Por vezes, a base remonta a um período pré-literário, mas a forma se contrapõe ao adjetivo correspondente (de onde pode talvez se ter originado). É o caso de: veterinarium "local onde se cuida das bestas" (Higino, latim-2), equivalente neutro do adjetivo deadjetival veterinarius (de veterinus) e de valetudinarium "hospital, enfermaria" (Sêneca, o moço, latim-2), correspondente a valetudinarius "doente", de valetudo "(má) saúde". O termo præsidiarium "posto militar" (Notas Tiron., latim-2) pode derivar diretamente do adjetivo præsidiarius "designado como guarda" ( $\leftarrow$ præsidium "proteção, defesa"). Um deverbal pode ser flagrado em prompt(u)arium "armário, loja" (Apuleio, latim-3), equivalente a promptuarius "onde se conserva", derivado do particípio promptus do verbo promo "abrigar". O mesmo se vê em secretarium "local ermo" (Apuleio, latim-3), ligado ao particípio secretus, do verbo secerno "separar", destrictarium "local de massagem" (CIL), baseado no particípio destrictus, do verbo destringo "esfregar". Outros exemplos: legatarium "legado, doação" (Schol. Juv.) paralelamente a legatarius "aquele a quem se faz uma doação" e cruciarium "crucificação" (Comodiano, latim-3), ao lado de cruciarius "crucificado $(\leftarrow$ crux)". Talvez ao mesmo grupo se integre scutarium "cargo de escudeiro" (Carísio, latim-3), equivalente neutro a scutarius ("escudeiro"), por sua vez um adjetivo substantivado e igniarium "que dá o fogo" (Plínio, latim-2) cf. igniarius "de fogo"< ignis'.

A ampla interpretação de $Y$ e de $V$ pode dar margem a várias criações lexicais: assim, carnarium é "gancho onde se pendura carne" (Plauto, latim-1), vinarium é "vaso onde se coloca o vinho" (Plauto, latim-1) e panarium "cesto onde se coloca o pão" (Varrão-1). O Y = local pode, em cada vocábulo, refletir um gênero específico de objetos e geral alguma produtividade. Outros exemplos: $Y=$ caixa em librarium "caixa de papéis, i.e. onde se guardam livros (liber)" (Cícero, latim-2); $Y=$ estojo em graphiarium "estojo onde se guardam os estilos" (Marcial, latim-2) ou em pennarium "estojo onde se guardam as penas" (Teodoro Prisciano, latim-3); $\mathrm{Y}=$ aparelho, em: vaporarium "calorífero, i.e. 
aparelho onde se produz vapor" (Cícero, latim-2) ou muscellarium "ratoeira" $\left(\leftarrow^{*}\right.$ muscellus "ratinho" em vez de musculus) (Gloss): no mesmo caso, como reforço, talvez explique o sufixo aparentemente vazio ballistarium "besta (arma)" $(\leftarrow$ ballista "besta") (Plauto, latim-1), se não se trata de um antigo diminutivo.

Alguns gêneros (i.é, hiperônimos) podem apresentar alguma produtividade, como é o caso de "vaso" que pode ter dado azo à formação, por exemplo, de oss(u)arium "vaso/urna onde se depositam os ossos" (Ulpiano, latim-3), fabatarium "vaso onde se cozem as favas" ( $\leftarrow$ fabata "purê de favas") (Lâmpridas, latim-3), unguentarium "vaso para perfumes (unguentum)" (S. Agostinho, latim-4), congiarium "vaso que contém um congius (unidade de medida)"(Digesta, latim-4), atramentarium "tinteiro, i.e vaso em que se guarda a tinta negra (atramentum)" (Vulgata, latim-4), chrismarium "vaso de relíquias" $(\leftarrow$ chrisma "unção"); salsarium "recipiente onde se põe o molho" ( $\leftarrow$ salsus "comida condimentada") (Apício, latim-4). Esse desenvolvimento gerará em português vários significados de -eiro (saleiro, açucareiro etc.). Talvez aqui se encontre alguma explicação para mortarium "pilão" (Plauto, latim-1), de base obscura.

Vários dos exemplos acima também podem ter uma interpretação final ou instrumental ("Y onde se $V X ">>$ "Y para se $V X^{\prime \prime}$ ou"Y com que se $V X "$ ), que ocorre quando não é mais possível uma interpretação locativa, em muscarium "mata-moscas" (Virgílio, latim-2), a saber "objeto com que se matam moscas", sudarium "lenço (com que se seca o suor)" (Catulo, latim-2). Nesse último caso, encontra-se um deverbal $(\leftarrow$ sudo), bastante incomum nesse período, mas também presente em battuarium "instrumento para socar" (广battuo). Uma interpretação final se encontra em horarium "relógio" (Censorino, latim-3), orarium "lenço para secar o rosto (os)" (Sto. Agostinho, latim-4) ou em bracchionarium "bracelete, i.e. objeto para se usar/ enfeitar o braço", que possui um curioso interfixo $-o n-(\leftarrow$ bracchium $)$. Deste mesmo subgrupo pertence, provavelmente salivarium (ou salibarium) "freio/brida do cavalo" $(\leftarrow$ saliva) (Diocleciano).

Raramente mais de um elemento é explicitado e isso só ocorre em formações compostas e derivadas tardias. Temos em aquimanarium ou aquiminarium "bacia onde se coloca a água nas mãos" (Ulpiano, latim-3) algo como "Y em que se $V X^{1}$ em $X^{2}$ " e em 
ceroferarium "candelabro, i. e. objeto em que leva a cera" (Gelásio, latim-4), algo como "Y em que se $X^{\vee} X^{\prime \prime}$. Tais construções não são produtivas e devem ser decalques do grego.

Outro gênero que se desenvolve dessas palavras é o de "móvel": armarium "local onde se guarda os utensílios (arma)" (Plauto, latim-1), urnarium "armário/mesa em que se depositam as urnas" (Varrão, latim-1), paenularium "armário para manto com capuz (paenula)" (Nóvio, latim-2); vestiarium "armário de vestes" (Plínio, latim-2), chartharium "arquivo" (广charta) (S. Jerônimo, latim-4), ca(m)psarium "armário de vestimentas"(டcapsa "caixa"?) (Gloss).

Em algum momento, -arium passou a referir-se também a dinheiro: impostos, multas e prêmios.O mais antigo exemplo é vasarium (Catão, latim-1) "custo da locação de uma prensa de azeitonas". A relação entre $\mathrm{V}$ e $\mathrm{X}$ pode ser complexa, possibilitando diversas regências, como se pode ver nas paráfrases. Outros exemplos são: columnarium "imposto por coluna", cerarium "imposto da cera" (Cícero, latim-2); ostiarium "imposto afixado nas portas" (César, latim-2); linguarium "multa por ter língua grande" (Sêneca, o moço, latim-2); honorarium "soma paga para o novo titular de um cargo" $(\leftarrow$ honor "testemunho de consideração e de estima, homenagem") (Plínio, o moço, latim-2), locarium "preço de um terreno" (Vitrúvio, latim-2); clavarium "indenização referente aos pregos (clavus) dos sapatos" (Tácito, latim-2); unguentarium "dinheiro para comprar perfume" (Plínio, o moço, latim-2), calce/iarium "indenização concedida para a compra de sapato" (Suetônio, latim-2); octavarium "imposto do oitavo" (Cod. Justin., latim-4), pararium "pagamento dobrado de um cavaleiro que tem dois cavalos" ( $\leftarrow$ par ) (Paulo de Festo latim-4), solarium "imposto predial (i.e, relativo ao solum)" (Digesta). No CIL encontram-se ainda outros: exsequiarium "dádiva feita na ocasião das exéquias (exsequiæ)", foricularium "imposto aduaneiro (i.e, foricula)", cisiarium "abatimento para carroças (cisium)", scamnarium "direito a um banco (scamnum)". Nas inscrições: rotarium "pedágio por roda", pittaciarium "custo de uma permissão (cf. pittacium 'pedaço de couro ou de pergaminho')".

A palavra palmarium "prêmio da vitória" (Gloss), o sufixo é um reforço de palma, com o mesmo sentido. O mesmo ocorre com o termo missarium (Schol. Juv.) "prêmio de 
combate ", que equivale a missum. Aparentado a esse grupo talvez seja heminarium "dádiva pesando uma hemina (medida de capacidade)" (Quintiliano, latim-3).

Um dos sentidos adjetivais que será mais produtivo nas língua românicas, sobretudo no português, é uma especialização para o significado de vegetal, sobretudo árvores frutíferas. Esse fenômeno já desponta no latim vulgar, em que, por meio da elisão do substantivo, ocorre a incorporação do valor semântico "árvore" pelo sufixo, como em arbor piraria > piraria > pereira. O valor de $\mathrm{X}$ é, preponderantemente, um fruto, mais raramente uma flor ou outra parte do vegetal. Os substantivos -arium neutro não é, porém, produtivo, mas no corpus flagram-se dois casos interessantes em palavras relativamente antigas, que, talvez denunciem uma produtividade abortada: vitiarium "vinhedo" ( $\leftarrow$ vitis "vinha") (Catão, latim-1); violarium "pé de violeta" ( $\leftarrow$ viola "violeta") (Virgílio, latim-2).

Dos sentidos básicos nascem ainda várias palavras de difícil paráfrase, uma vez que seus gêneros nem sempre nos dão pista de sua pertinência a algum dos sentidos já apresentados ou se formam, eles mesmos galhos isolados. São deverbais de formação complexa: auctarium "excesso, sobra, demasia" $(\leftarrow$ auctus, particípio do verbo augeo "crescer") (Plauto, latim-1), tectarium "tampa" ( $\leftarrow$ tectus, particípio do verbo tego "cobrir") (Catão, latim-1), torcularium "prensa, lagar" ( $\leftarrow$ torqueo, com interfixo $-u l-)$ (Catão, latim1), compendiarium "caminho mais curto" ( $\leftarrow$ compendo "resumir")(Sêneca, o moço, latim2); incinerarium "ação de frisar em ferro quente" ( $\leftarrow$ incinero) (Carísio, latim-3)

Denominais de formulação obscura são: topiarium "obra do jardineiro decorador (topiarius)" (†topia "paisagem") (Plauto, latim-1); dictabolarium "dito picante, sarcasmo" (Labério, latim-2); terrarium "elevação de terra" (Inscr); pessarium "chumaço de linho (para feridas)" (Teodoro Prisciano, latim-3); motarium " linho (para feridas)" (Célio Aureliano, latim-4); elect(u)arium "preparado farmacêutico" (Plínio Valeriano, latim-3); levitonarium "vestimenta sem manchas usada pelos monges egípcios" (Isidoro, latim-4); lucernarium "momento em que se alumiam as lâmpadas" (டlucerna)(Sto. Agostinho, latim-4); sagmarium "carga posta numa albarda" $(\leftarrow$ sagma) (Sérvio, latim-4); sacramentarium "ritual para a administração dos sacramentos" (Genádio, latim-4); 
rationarium "estatística, estado (de algo)" $(\leftarrow$ ratio do part. ratus, do verbo reor) (Suetônio, latim-2).

Na passagem do latim para o português, pouquíssimas dessas palavras sobreviveram, contudo, é possível detectar nelas o germe que causará futuras produtividades. A lacuna oferecida pelo ibero-romance convida-nos a uma pesquisa à parte, a ser feita, com base nos indícios dos corpora de latim medieval.

O valor diminutivo grego é bem raro, mas de longe esteve ausente na formação do português, como testemunha o significado da palavra igrejário (veja capítulo 2). O valor básico de -arius, $-a$, -um, porém, a saber $X]_{\text {eiro }}=$ que é de $X$ está presente apenas em formas cultas: diário, salário e terciário, embora haja também uma forma herdada, a saber, terceiro. A forma neutra não ocorre com uma importante derivação de -arius, a saber $X]_{\text {eiro }}=$ pessoa que $(V) X$ e derivadas. Também o tão produtivo sentido $\left.X\right]_{\text {eiro }}=$ árvore que produz $X$ não é suficientemente representado nas poucas plantas que se representam com-arium neutro.

Por outro lado, os sentidos referentes a objetos, a saber $X]_{\text {eiro }}=$ objeto em que se (V) $X$ ou $V]_{\text {eiro }}=$ objeto em que se $V$ se mostram bastante produtivos e sobretudo é importante observar o sentido derivado, $X]_{\text {eiro }}=$ lugar em que se (V) $X$, que originou, a partir de galinheiro (testemunhado no português apenas no século $X V$ ), uma série de outras formações semelhantes. Formações cultas baseadas no corpus estudado seriam apiário, aviário, aquário, santuário. Também a formação de sumário, sudário e horário baseiam-se como complexas relíquias da lógica dos sentidos apresentados acima, se lhe quer atribuir algum sentido que não seja falseado por uma explicação sincrônica desnecessariamente equivocada. Também é curioso observar que já se encontrava produtivo o sentido $X]_{\text {eiro }}=$ muito $X$ (como em nevoeiro), resultado de uma convergência do resultativo do sentido locativo com o significado principal do sufixo homófono de origem grega (glossarium).

Numa árvore genealógica de um sufixo como -arium, dentro de qualquer recorte sincrônico, conviverão sentidos antigos, metáforas, metonímias e especializações, cada qual, porém provinda de sincronias pretéritas distintas, mas que, entendidas de outro modo, dão o aspecto de algo caótico. A polissemia sufixal deve, porém, ser entendida 
como o resultado inevitável do movimento da língua, suas convergências e bifurcações. Línguas de contato e línguas de prestígio exercem pressões de variada intensidade, sob um certo sistema definido, em diferentes recortes sincrônicos, as quais, alavancadas pela forças estilísticas, estão sempre prestes a gerar subsistemas linguísticos. Nenhuma intersecção desses sistemas equivale à langue saussuriana.

A realidade de uma língua, politicamente definida, dessa forma é, sobretudo, diacrônica e diatópica. A produtividade de um sufixo ao gerar a sua mobilidade pode ser entendida ou como o acúmulo de formas sobreviventes ou como sua potencialidade gerativa, a qual varia, não só de sufixo para sufixo, mas também de acepção para acepção dentro do mesmo sufixo. Desse modo, especializações de -arium criadas no bojo do próprio latim serão mais ou menos prolíficas. Como a capacidade gerativa é inversamente proporcional ao número de sufixos concorrentes, é possível observar uma grande diferença dependendo de cada sentido que compõe o significado total do sufixo. 0 fenômeno da especialização, dessa forma, está associado a uma teoria estilística e a uma teoria da divulgação de fenômenos linguísticos, sobretudo no caso de conceitos novos e de formas novas (neologia). Nesses casos, o conflito de formas concorrentes altera a produtividade, gera arcaísmos ou adiciona à forma mais antiga uma especialização valorativa (sobretudo a pejoratividade). 


\section{OS SUFIXOS PORTUGUESES -EIRO E -ÁRIO}

Tanto -ário como -eiro/a/s provêm do mesmo sufixo latino -arius (m), -arium (n). O sufixo culto -ário apenas aportuguesou sua terminação, ao passo que -eiro (que, por provir diretamente do latim falado, tem seu étimo propriamente sob um acusativo -arium) sofreu metátese do iode (-airo) e consequente assimilação parcial, mais especificamente, alçamento e fechamento da vogal aberta (-eiro). Somente uma palavra rara (ladairo) contém a fase intermediária no corpus investigado (Houaiss \& Villar, 2001). Outras formas como -ária/s, provenientes do neutro plural ou do feminino, responsáveis por outras 242 palavras, não serão abordadas aqui. O sufixo -ário/a/s aparece, segundo o dicionário Houaiss, em 982 palavras do português e -eiro/a/s em outras 2625. Sufixos como -aria, ério, -ório têm outros étimos. Dessa forma, -ário/a/s corresponde a quase metade do número de verbete de-eiro.

Toda palavra de maior frequência tem mais de um milhão de ocorrências a partir de dados obtidos automaticamente por meio de busca no Google em 15/8/2006, restritas a páginas em português, numa base de cerca de 500 milhões de páginas em português ${ }^{17}$. O sufixo -ário surge com o sentido primitivo de "relativo a". É sempre com esse valor que entrará no português quando for um latinismo. Há contudo palavras formadas em português muito cedo, que podem ou não ter esse sentido básico.

O sufixo -ário ocorre em português já no século IX em textos de latim. A única palavra desse século (antifonário) revela bem o caráter erudito de sua forma, uma vez que se trata simplesmente de um aportuguesamento do latim medieval antiphonarium. Nela, aparece o sentido coletivo "objeto em que há muitos X". Do século XII até hoje sobreviveram outras duas palavras com o mesmo comportamento, breviário e denário, o primeiro com o mesmo sentido coletivo (derivado de algum valor substantivado de brevis) e o segundo, com valor adjetival "que (vale) X (asses)" (de deni).

No século XIII, as seis palavras mais frequentes (aniversário, calendário, contrário, necessário, salário, santuário) ainda são latinismos. Trata-se originalmente de adjetivos. 0

\footnotetext{
${ }^{17}$ Nossos agradecimentos a Zwinglio O. Guimarães-Filho (IF/USP), pesquisador do GMHP, pelos dados referentes à freqüência de uso e aos gráficos aqui apresentados.
} 
radical do adjetivo anniversarius é composto e o sufixo significa "que $\mathrm{X}$ (todos os) $\mathrm{Y}$ ". Da mesma forma calendarius é "que (ocorre) em X". O deadverbial contrarius seria "que está X". O deadjetival necessarius, da base necesse "inevitável" tem significado redundante "que é X" (da mesma forma que canhoto $\rightarrow$ canhoteiro). O termo salarius possui o significado básico do sufixo "que é de X", no entanto seu uso mais frequente, provindo do neutro salarium possui especificação do sentido geral da palavra. Já o neutro sanctuarium "local onde há (Y) X".

Outras palavras, com baixíssima frequência atualmente, como o já mencionado igrejário (vide capítulo 2) e porcionário, são formadas no português, a partir da depreensão de um sufixo -ário. O termo igrejário não significa, contudo, "relativo à igreja", mas tem um curioso valor diminutivo que provém certamente de um uso culto do sufixo grego -ápıov (aparentemente o uso coletivo é posterior), já porcionário possui o significado "que (recebe) X".

Com exceção de corsário, que seria um italianismo, todas as outras palavras formadas no mesmo século são palavras eruditas (vigário, vestiário, templário, ternário, falsário, notário, eletuário). A forma italiana corsaro revela certa produtividade do sufixo cognato -aro naquela língua românica. Vicarius é adjetivo deadverbial, ligado a vicem (que originou a palavra vez em português), portanto, o significado "que está X" pode ser-lhe atribuído. Vestiarius é, originalmente, um adjetivo adnominal cujo sufixo tem o sentido mais primitivo "que é de X". Ternarius funciona como denarius. A base mais primitiva de falsarius, "que é X", como necessarius. Esse valor redundante na verdade repousa sobre um neutro falsa "coisas falsas" $\rightarrow$ falsarius, que, já em latim, se torna substantivo, referindo-se a seres humanos. A mesma transição se encontra em notarius "que é de X", adjetivo denominal que sofre translação posterior para a categoria dos substantivos (no sentido de "estenógrafo, secretário"). Por fim, electuarium, aparentemente, tem sentido de "(preparado) de (Y) X".

No séc. XIV continua o valor latino básico nas palavras mais frequentes (armário, adversário, inventário, ordinário, proprietário, questionário, tributário). Vários valores aproximam -ário de -eiro, como se pode perceber. Se digo que uma determinada palavra 
derivada com o sufixo -ário equivale a algo "que é referente a $X$ " (sendo $\mathrm{X}$ a base de formação da palavra), entendo que pode ser "um objeto referente a $X$ " ou "uma pessoa referente a $X^{\prime \prime}$, o que faz subentender um verbo $V$ na maior parte das vezes. Um proprietário é uma "pessoa que (tem) uma propriedade", um armário é um "objeto (em) que (se guardam) armas". Esses valores embrionários ficarão bem claros em -eiro. A interpretação do verbo costuma mudar, por exemplo: quæstionarius era "pessoa que (faz) perguntas", mais especificamente, numa sessão de tortura, já hoje questionário é um "objeto (em) que (há) questões", ou seja, uma prova. O significado da palavra já tende a obscurecer o radical. Se em latim, a palavra armarium já era usada para móveis que guardassem outras coisas e não só armas, embora, com toda certeza, houvesse consciência da base formadora, já em português, sua base já se tornou opaca bem cedo, uma vez que sofre uma dissimilação (motivada possivelmente por analogia) e almário é uma das variantes dessa época. O termo adversarius originalmente se liga a adversus "voltado para, face a face" (particípio de advertere), de modo que o derivado tem o sentido primitivo "que está X". Também o tardio inventarium tem base participial "documento em que se X (as propriedades)". O latim ordinarius é adjetivo denominal com sentido primitivo "que é de X". O mesmo se pode dizer de tributarius.

Do séc. $\mathrm{XV}$, datam-se aquário, centenário, comentário, extraordinário, secundário, sumário, voluntário, todas formadas em latim clássico. Além dessas, há plenário, secretário, criadas pelo latim medieval. O termo aquarius originalmente tem o sentido básico, mas logo deriva o sentido de profissão (abonado em Juvenal, donde a mudança do significado da palavra derivada acaba por referir-se ao signo do zodíaco) e a forma neutra aquarium se restringirá ao de reservatório de água, sentido moderno da palavra. Centenarius tem o sentido básico e é um adjetivo deadjetival (como denarius, ternarius). A palavra commentarius/-ium, com base participial (verbo comminiscor) tem valor coletivo "conjunto de X": o valor de X é fruto de várias modificações semânticas da base. O termo extraordinarius é apenas uma composição prefixal de ordinarius. O deadjetival secundarius tem o valor "que está n(a sequência) X". De summus "o ponto mais alto" (superlativo do advérbio sub, por meio de *submus > summus) >> "o fim" (cf. advérbio 
summō), donde summarium "que está em X". Originalmente, voluntarius é adjetivo denominal "que (age) com X".

O termo medieval plenarius aparentemente significa "que é $\mathrm{X}$ " e só depois adquire valor de substantivo. Também secretarius é uma profissão, cujo conteúdo semântico é diretamente derivável do sentido do sentido básico "que (trabalha com assuntos) X".

No século $\mathrm{XVI}$, as mais comuns seriam (provenientes do latim): imaginário, judiciário, prontuário, seminário, temporário, veterinário; (do latim medieval): dicionário; (formadas no português ou empréstimo): bancário, penitenciário. O termo latino imaginarius tem o sentido básico, mas logo passa a designar profissão ("o que (carrega) $\mathrm{X}^{\prime \prime}$ ). O sentido atual provem da própria polissemia do substantivo primitivo imago “imagem, imitação" > "representação" > "aparição, ficção". O termo judiciarius tem o sentido básico preservado. Promptuarius, formado sobre o particípio promptus (do verbo promĕre) "retirar" tem valor locativo "lugar onde se $\mathrm{X}(\mathrm{Y})$ ". Em Plauto tem o sentido de "prisão", mas no latim tardio, a forma neutra promptuarium "lugar de onde se X" pode significar "armário, loja". O termo seminarius (derivado de semen) tem valor original "que é de X", na forma neutra seminarium derivam-se valores muito abstratos para a palavra derivada. $\mathrm{O}$ adjetivo temporarius tem valor original (muitas vezes com tempus com valor derivado de "circunstância"). O termo veterinarius, adjetivo deadjetival (cf. veterinus "relativo às bestas de carga"), também tem o valor original. O latim medieval dictionarius é um adjetivo denominal que passa a ser usado como substantivo, passando do valor primitivo ao coletivo quando utilizado na forma neutra dictionarium. O termo francês dictionnaire ocorre antes do português no mesmo século. O termo vernáculo bancário possui sufixo com valor original e tem origem italiana bancario. Idem penitenciário, proveniente via francês pénitencier ou do latim medieval pænitentiarius.

Os mais comuns do séc. XVII seriam: (do latim) agrário, formulário, literário, operário, primário, rosário; (do latim medieval): vocabulário. O termo agrarius tem valor primitivo. Idem formularius (sendo o sentido coletivo bastante tardio). 0 mesmo se pode dizer de litterarius, com base metaforizada bem cedo. Operarius é inicialmente um adjetivo denominal com valor primitivo, mas cedo adquire o valor substantivo. Primarius 
segue o mesmo padrão de secundarius. O termo rosarius tem valor primitivo também, sendo o substantivo proveniente da forma neutra rosarium, palavra cujo significado sofre polissemia por meio de metáforas. O latim tardio vocabularium segue o mesmo valor coletivo de dictionarium.

Quanto ao séc. XVIII, (latim): diário, glossário, horário; (francês): mobiliário, funcionário. O latim tardio diarium tem o valor inicial do sufixo. Glossarium vem do grego

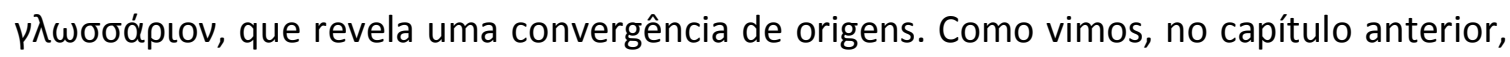
o sufixo -ápıov é um diminutivo, que é reinterpretado como coletivo. O termo horarium, aparentemente, mantém o sentido diminutivo no latim tardio horarium, mas é reinterpretado no latim medieval horarius a partir dos significados básico e coletivo. 0 francês mobilier também produz os dois significados. Fonctionnaire parte do sentido "pessoa que tem X".

No tocante ao português contemporâneo, os mais comuns do século XIX seriam: (latim) balneário, beneficiário, monetário, usuário; (latim tardio): cenário, unitário, vestuário (francês): anuário, destinatário, estagiário, ferroviário, imobiliário, intermediário, revolucionário, sanitário, solidário, universitário; (italiano): empresário; (português): comunitário. O termo balnearius é adjetivo com valor primitivo, sendo a forma neutra no plural balnearia a fonte da formação do substantivo correspondente. $O$ termo beneficiarius é adjetivo relacionado a beneficium e também substantivo já em latim. A palavra monetarius (valor básico ou profissão) tem uma base participial moneta com significado bastante transformado. Vsuarius é tardio e significa inicialmente "de que se tem X" e, posteriormente, "pessoa que V". O latim tardio scænarium significa "local onde (ocorre) X". Vnitarius, de formação medieval, vincula-se ao particípio de unire e tem sentido "que está X". A palavra medieval vestuarius significa "conjunto de X".

O francês annuaire, criado a partir do latim annuus é um adjetivo deadjetival sem alteração do significado da base. Destinataire tem base participial com o sentido dativo, a saber, "pessoa a quem se X", que terá alguma produtividade futura, correspondendo à parte não-ativa de uma ação, expressa por -(d)or (cf. locador/ locatário). O francês stagiaire tem valor de profissão derivado do sentido básico. Ferroviaire, com base 
composta (conforme a tradição de outras palavras) tem o significado básico do sufixo. Immobilier também foi criado com mesmo valor semântico original. Intermédiaire é algo "que está X", ou seja, intermedius "intercalado". O francês révolutionnaire apresenta o mesmo valor inicial do sufixo. Sanitaire, derivado culto sobre uma base latina irregular sanitas (em vez de sanitat-), também recupera o valor semântico mais antigo do sufixo. Por fim, o mesmo se pode dizer de universitaire, construído de forma igualmente irregular sobre universitas (em vez de universitat-). Solidaire é um termo antigo no francês (séc. XV) montado sobre a expressão jurídica latina in solidum "para todos". O valor sufixal, apesar da transformação semântica da base, é o mais antigo.

O italiano impresario é uma profissão sobre uma base participial de valor modificado semanticamente. Notiziario, entendido como "conjunto de X" é a provável fonte da palavra portuguesa. Ambas as palavras também ocorrem no espanhol: empresario, noticiario. O português comunitário é provável decalque de outras línguas: inglês communitary/ -ian, italiano com(m)unità, espanhol comunitario: seu sufixo tem o mesmo valor semântico e formação irregular de sanitaire e universitaire.

Mais comuns do séc XX (francês): documentário, publicitário, (português): agropecuário, rodoviário. Documentaire também tem o sentido primário do sufixo, embora a palavra tenha restringido seu uso por incorporação semântica do substantivo que regia (film documentaire). A mesma construção irregular ocorre em publicitaire, criando a possibilidade de segmentação sincrônica -itário referente a -idade (universitário/ universidade, comunitário/ comunidade, publicitário/publicidade), correspondente a 68 palavras do corpus. O significado do sufixo é o primitivo. 0 termo agropecuário é composição a partir de pecuário, que remonta ao latim pecuarius, também com sufixo com significado antigo (também ocorre no espanhol agropecuario). A palavra portuguesa rodoviário tem a mesma formação de ferroviário, ou seja, também se vale do significado antigo.

Comparando o gráfico de prolificidade do sufixo -ário (gráfico 4) como o do sufixo -eiro (gráfico 5), observamos, ao lado de uma constante relação entre um crescente número de verbetes criados, um decrescente uso dos mesmos verbetes, de modo que se 
pode afirmar que as palavras antigas são as mais usadas. Esse dado curioso talvez revele apenas um fato conhecido: palavras arcaicas não são citadas em dicionários modernos, ao passo que muitas palavras modernas aparecem como verbetes, apesar de seu pouco uso.

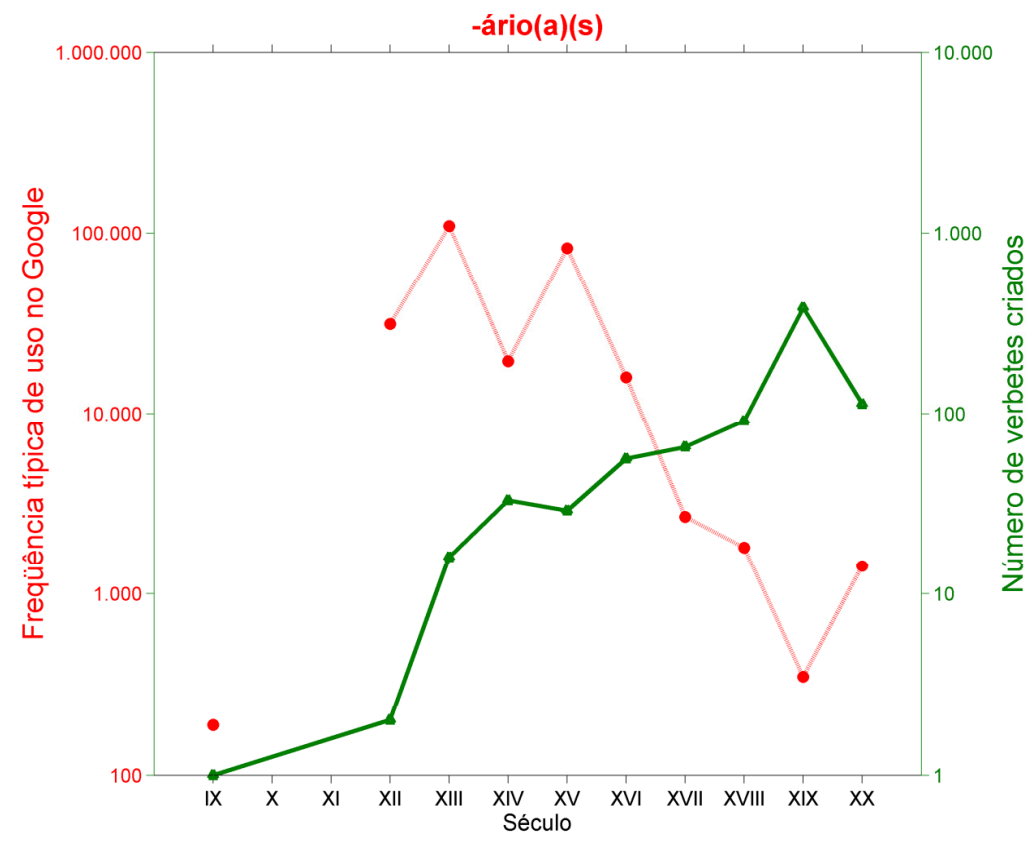

Gráfico 4 - Prolificidade de -ário

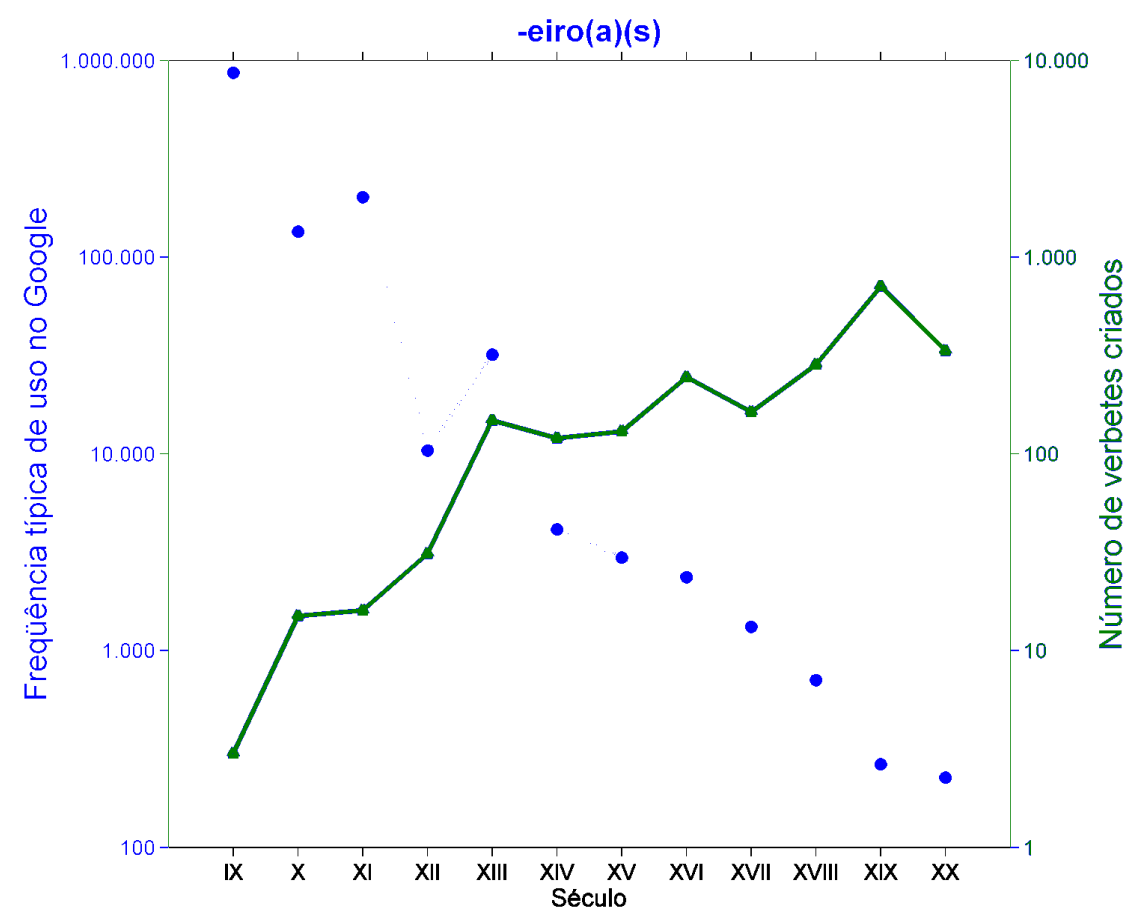

Gráfico 5 - Prolificidade de -eiro 
De qualquer forma, observa-se que o sufixo - eiro tem tido uma produtividade cada vez menor, ao passo que -ário cresceu levemente no último século. O sufixo -eiro sofre bastantes concorrências: para indicar profissões, por exemplo, concorre ultimamente com -ista. Tendo adquirido cada vez mais um valor pejorativo, -eiro está associado a profissões menos qualificadas. Poucos nomes de árvores novas são introduzidas no idioma e os gentílicos são pouquíssimos. Também o uso coletivo sofre concorrência com muitos outros sufixos.

Com base no gráfico 3 temos uma primeira versão da árvore genealógica de -ário. As letras gregas referem-se aos significados advindos da origem grega, ao passo que as em alfabeto latino estão associados originariamente ao -arium latino. A ordem das letras se deve ao fato de muitos significados serem semelhantes ao de -eiro como se verá no capítulo seguinte. A maior parte dessa polissemia, como visto, remonta a uma etapa anterior ao latim (exceção apenas para o significado $\theta$ ).

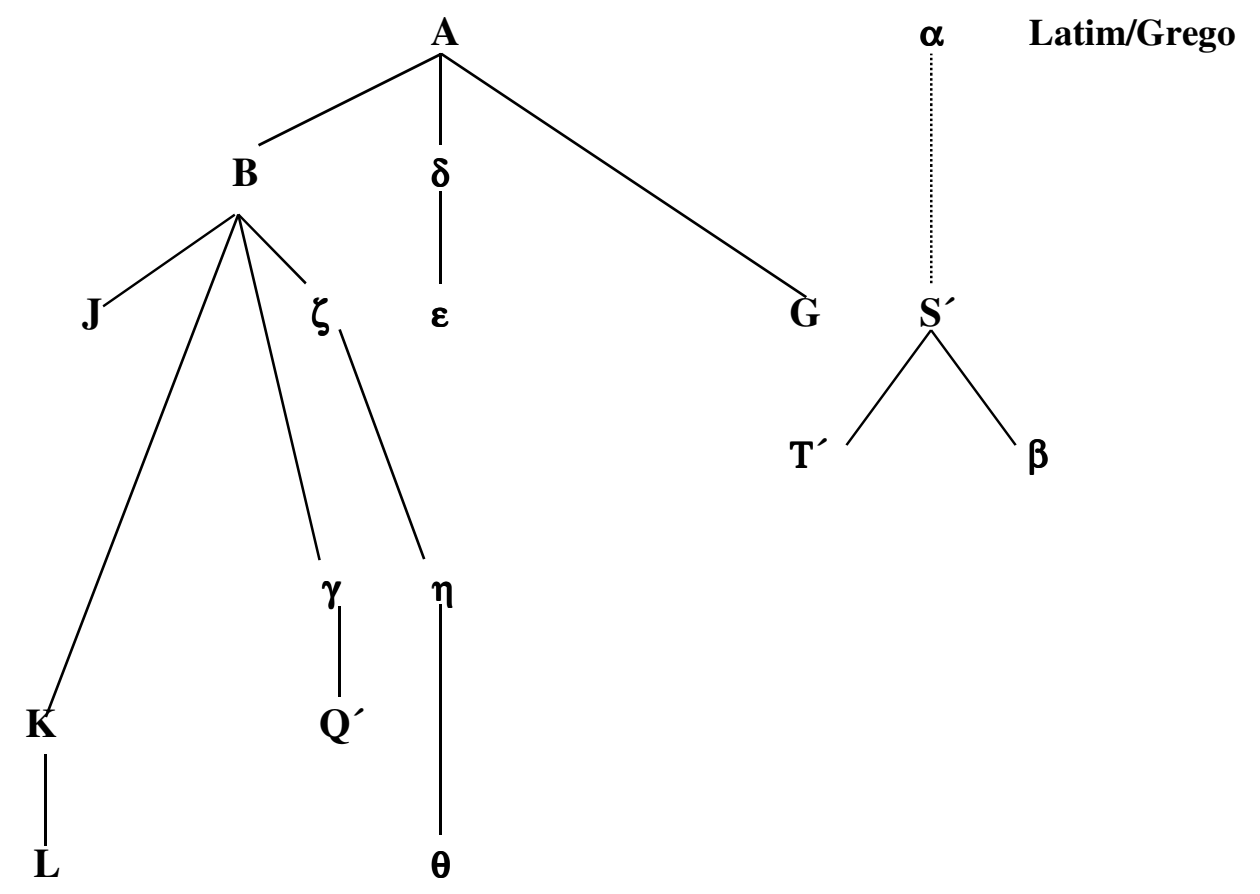

Gráfico 6 - Transformações do sufixo -ário. 
Paráfrases:
( $\alpha) \quad X]_{\text {ário }}=X$ pequeno
(B) $\quad X]_{\text {ário }}=$ conjunto de $X$
(X) $\quad \mathrm{V}]_{\text {ário }}=$ lugar onde $\mathrm{V}(\mathrm{X})$

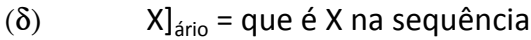
(घ) $\quad X]_{\text {ário }}=$ que tem $X$ (unidades)

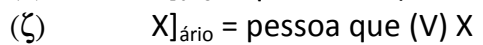
( $) \quad V]_{\text {ário }}=$ pessoa que $V(X)$
( $\theta) \quad V]_{\text {ário }}=$ pessoa a quem se $\mathrm{V}(\mathrm{X})$
(A) $\mathrm{X}$ ário $=$ que é de $\mathrm{X}$
(B) $\quad \mathrm{X}$ lário $=$ que $(\mathrm{V}) \mathrm{X}$
(G) X]ário = que é $\mathrm{X}$
(J) X $]_{\text {ário }}=$ que está em $\mathrm{X}$
(K) $\quad \mathrm{X}]_{\text {ário }}=$ objeto onde $(\mathrm{V}) \mathrm{X}$
(L) V]ário $=$ objeto onde $\mathrm{V}(\mathrm{X})$
(Q) V] $\quad$ ário $=$ objeto onde (V) X
(S') $\quad \mathrm{X}]_{\text {ário }}=$ que tem muitos $\mathrm{X}$
(T) $\quad \mathrm{X}]_{\text {ário }}=$ escrito que tem muitos $\mathrm{X}$

A semelhança desses significados formados independentemente, em épocas distintas, em -ário e -eiro não deixa de ser intrigante, uma vez que outros sufixos, quando adquirem valores concorrentes, também têm alguma propensão de desenvolverem sentidos correlacionados, como é o caso de -ista (Areán-García, 2007). As mudanças semânticas têm muito a ver com visões socioculturais, mas há algum elemento universal, à maneira dos apresentados por Heine \& Kuteva (2002). 


\section{7) O SUFIXO -EIRO NUM CORPUS DO PERÍODO MEDIEVAL}

O percurso diacrônico dos sufixos portugueses é, de modo geral, muito pouco conhecido ${ }^{18}$. Quando se concentra a atenção em um sufixo de alta produtividade, como é -eiro, observa-se que há uma diversidade semântica nos adjetivos e substantivos por ele formados. O sufixo, às vezes, está associado a profissões (marceneiro, açougueiro), às vezes, a árvores frutíferas (pereira, macieira), a palavras abstratas (besteira), a objetos em se guarda algo (saleiro, açucareiro), entre outros. A antiguidade desses significados não é a mesma.

Como já dissemos, -eiro provém de -arium, tal como -ário do capítulo 5. O sufixo arium ter-se-ia transformado em ${ }^{*}$-ariu e, posteriormente, por metátese, em *-airu no latim vulgar ${ }^{19}$. No entanto, se do ponto de vista formal, essas transformações fonéticas são inquestionáveis, a modificação semântica e a distribuição lexical não sempre foi bem compreendida. O longo percurso da história do latim e sua transição para as línguas românicas reserva alguns problemas ainda não totalmente resolvidos.

Coletaram-se todas as ocorrências de -eiro(s), -eira (s) num corpus representado das 420 cantigas de Santa Maria, de Afonso X (1252-1284), que foram compostas no último quartel do século XIII (entre 1274 e 1282). Ao todo, extraídos os casos que não tinham relação com -arius (mosteiro, cheiro, lazeira) e outros de etimologia duvidosa (fazfeiro, beira) foram obtidos 84 vocábulos. Um exame da etimologia desses vocábulos mostra que sua formação se deu em momentos diferentes. É possível separar os seguintes momentos de formação:

\footnotetext{
${ }^{18}$ Diretamente ligadas ao tema desta tese, citem-se aqui as dissertações dos integrantes do GMHP defendidas na Faculdade de Filosofia, Letras e Ciências Humanas, da Universidade de São Paulo: Lacotiz (2007), Areán-García (2007), Freitas (2008), Gianastacio (2010), Gonçalves (2009), Simões (2009) e Santos (2010).

${ }^{19}$ A pronúncia [ej] é resultado da assimilação parcial regressiva, por causa da influência da semivogal, que promoveria o alçamento $a>e$. Dessa forma manteve-se no galego e no português europeu setentrional. A mesma semivogal caiu em castelhano, no português europeu meridional e em diversas áreas da Lusofonia (entre elas, o Brasil), onde prevalecem a monotongação [e]. Na área central de Portugal, incluindo Lisboa, houve também a manutenção do iode, às custas de uma dissimilação do [e], criando a pronúncia [ej], que é a pronúncia padrão europeia atual.
} 
a) Vocábulos documentados no período dos séculos VII a III a.C., cuja listagem formaria um vocabulário latino arcaico;

b) Vocábulos documentado no período pré-clássico e clássico (séculos III a.C. a I d.C.);

c) Vocábulos documentados no período tardio do Império (séculos II a V d.C.);

d) Vocábulos documentados na Alta Idade Média (séculos V a XI);

e) Vocábulos hipotéticos do latim vulgar das épocas (b) e (c);

f) Vocábulos hipotéticos de caráter regional 'romances' (séculos IX a XIII);

g) Vocábulos documentados nas línguas românicas na época (f).

Na prática, é difícil reconhecer as etapas, uma vez que o latim escrito falseia as características fonéticas que facilitariam o reconhecimento do período. Num texto posterior ao séc. IV encontra-se homicidiarius (Pan. ad Const. 4), palavra que gerará omezieiro (213:94), também presente em castelhano (COROMINAS sv. "hombre"). O significado é o mesmo: "homicida". Duas dúvidas se impõem, com referência à formação e ao significado:

1) A palavra omezieiro é fruto de tradição contínua de homicidiarius? A manutenção do conteúdo semântico que as une e as transformações fonéticas justificariam uma resposta afirmativa a essa indagação.

2) Dada a raridade de abonações é possível admitir que sejam formações independentes, ou seja, frutos, respectivamente, de homicidium+arius e de omezio+eiro? Outros casos, em que há significados completamente distintos (carnarius "local em que se coloca a carne, isto é, o corpo do defunto=túmulo" e carneiro "animal útil por causa da carne, em oposição àquele que servia para a procriação"), mostram que essa hipótese não é de todo absurda.

Uma terceira dúvida também apareceria, embora não seja aplicável nesse caso específico, devido à datação de homicidiarius: a forma latina documentada não se trata de uma transposição do romance para o latim? Ou seja, homicidiarius não seria uma forma latinizada do romance que gerou omezieiro? Uma pesquisa sobre a localidade dos manuscritos em que aparecem homicidiarius talvez pudesse responder a isso.

Das palavras cuja etimologia se encontra documentada nos textos latinos das etapas (a), (b) e (c) listadas acima, citem-se, com certeza, primeiro, terceiro, ceveira, dinheiro, obreiro, senlheiro e febreiro, de primarius, tertiarius, cibaria, denarius, operarius, singularius, februarius $(8,43 \%)$. Todas elas passaram para o latim vulgar, embora nem todas sejam documentáveis no romeno e, no caso de senlheiro, apenas na Península Ibérica. Observa-se a preponderância do valor adjetivo das palavras derivadas nessas palavras antigas. O traço semântico relativo a profissões desponta apenas em operarius, 
que origina obreiro. Além dessas, outras palavras também poderiam ser incluídas: cavaleiro, escudeiro, usureiro, lumeeira (4,81\%), mas o significado mudou das etapas (a) e (b) para (c) e (d): caballarius "que monta mau cavalo" passou a significar "cavaleiro", scutarius "fabricante de escudo" tornou-se "quem carrega o escudo", usurarius "relativo ao uso" tornou-se "que vive de lucro", luminaria "que produz luz" tornou-se "vela".

Alguns termos surgem no latim tardio, da etapa (c), com valor de profissões. Listemse, com certeza, pegureiro, porteiro e figueira de pecurarius, portarius, ficaria $(3,61 \%)$, que também passaram para o latim vulgar. O termo ficarius "relativo a figos" já significava "figueira" sob a forma ficaria no séc. IV e tem distribuição irregular no latim vulgar, uma vez que só aparece no Norte da Itália e na Península Ibérica. Somadas a essas estão palavras com forma ou valor semântico alterado: caldeira e fogueira (2,41\%). A forma caldarium "relativo ao calor" passou a significar "caldeirão", já no séc. IV, mas a forma *caldaria é vulgar; focaria "cozinheira", palavra tardia gera o sentido vulgar pan-românico, não-documentado, de "fogueira" na mesma época.

Importantes para a caracterização de um latim medieval ibérico são vocábulos documentados na etapa (c) e (d) são: tesoureiro, terreiro, baesteiro, semedeiro, merceeiro, omezieiro de thesaurarius, terrarium, ballistarius, semitarius, mercedarius, homicidiarius (7,23\%). Todas essas formas sobreviveram na Península Ibérica, mas provavelmente tiveram uso mais amplo no final do Império. Além dessas, duas outras palavras: denteira e seeleira $(2,41 \%)$ podem gerar dúvidas, mas são provavelmente referentes às etapas (f) ou (g). A palavra denteira no sentido de "careta em que se mostram os dentes" parece ocorrer só no português e é derivação tardia de dentarius "referente aos dentes". Também a palavra seeleira "bolsa para guardar selos" é derivação tardia exclusiva do português, embora haja sigillarius "fabricante de selos" em inscrições tardias.

Somadas a essas, encontram-se duas outras palavras, a saber, maneira e ribeira $(2,41 \%)$, cujas etimologias são documentáveis nas etapas (a), (b) e (c), mas adquirem sentidos específicos na etapa (d): manuaria provém de manuarius "relativo às mãos", donde "habilidade, modo, maneira"; riparia, de riparius "relativo à margem", donde "terreno adjacente às margens do rio". Esses significados aparecem documentados no 
latim medieval (riparia aparece com este sentido em 1021) e foram cunhados regionalmente, provavelmente na França, de onde irradiou para toda a Europa Medieval, inclusive Portugal. Também devem ter surgido na França, na etapa (e), formas como *carraria, *companiarius, *archarius, *marinarius, *werrarius que aparecem em outras línguas românicas (mas não no romeno), entre elas o português: carreira, companheiro, arqueiro, marinheiro, guerreiro $(6,02 \%)$.

Quanto à etapa (f), o ibero-romance gera formas presentes tanto no português quanto no castelhano (38,55\%): monteiro, certeiro, arteiro, moleira, parleiro, vozeira, dereitureiro, justiceiro, covilheira, verdadeiro, torticeiro, evangelisteiro, cabeceira, caleiro, vidreira, mentireiro, outeiro, postremeiro, fronteiro, duradeiro, herdeiro, falcoeiro, mandadeiro, dianteiro, sombreiro, esmoleiro, prazenteiro, carneiro, cordeiro, solteiro, tendeira, despenseira. A esses, devem-se incluir formas que são presentes apenas no português, isto é, características de uma etapa (g): terreiro, vertudeiro, sabedeiro, azinheira, giesteira (6,02\%). Outras, formaram-se independentemente, com sentidos diferentes no castelhano e no português: grueiro, pedreiro $(2,41 \%)$. Por fim, algumas formas só aparecem no castelhano em registro dialetal e tardio: regueiro, costeira, terronteiro $(3,61 \%)$.

Ainda na etapa $(\mathrm{g})$, decorrentes de outros romances, aparecem palavras de origem estrangeira. Comuns ao ibero-romance e ao provençal estão: ovelheiro, capeirão, mercadeiro (3,61\%). Do francês provêm ligeiro, mineira, barreira, peleteiro, fronteira (6,02\%). Do francês ou do italiano: taboleiro, romeiro (2,41\%).

Se se separam duas etapas: uma que inclua de (a) a (e), anteriores às línguas românicas e outra, posterior à escrita dessas línguas, isto é, (f) e (g), obtêm-se os seguintes valores: 29 palavras (34,94\%) foram formadas e mantidas durante o primeiro grupo e $54(65,06 \%)$ a partir do segundo. Isso mostra que a produtividade de -arius ampliou-se muito no ibero-romance. Se se imagina uma terceira etapa, até os dias de hoje, observa-se que dessas 83 palavras, 65 ainda se usam ou, ao menos, estão abonadas no dicionário Houaiss $(78,31 \%)$. 
Do ponto de vista da derivação, -eiro forma substantivos e adjetivos que podem ser denominais, deadjetivais, deadverbiais ou deverbais. Todavia, nem todas as possibilidades foram produtivas em todas as épocas.

Dos séculos VII a.C. a I d.C. (7 exemplos) há, no corpus deste capítulo, apenas substantivos denominais e sobretudo adjetivos deadjetivais. O único caso de substantivo deadjetival é dinheiro. Apenas uma ocorrência de substantivo com valor semântico de "profissão" (obreiro). Paralelamente, com datação entre III a.C. e V d.C. (11 exemplos) só há substantivos (denominais e deadjetivais), dos quais muitos (45,45\%) são profissões, há um crescente número de indicações locativas (caldeira, ribeira, fogueira) e um vegetal (figueira). Do latim tardio e medieval (6 exemplos), continua a predominância de substantivos denominais, mas também há adjetivos (um deadjetival e outro deverbal: merceeiro). Paralelamente, as formas hipotéticas (ao todo 5 exemplos) para o intervalo entre III a.C. e XIII d.C. aponta para a maioria de substantivos denominais, a maioria denotadores de profissões.

As formas mais recentes, do séc. IX a XIII (ao todo 54 exemplos) são sobretudo substantivos denominais $(55,55 \%)$ seguidos de adjetivos denominais $(14,81 \%)$, adjetivos deadjetivais e denominais (ambos com 11,11\%), substantivos deadjetivais $(9,26 \%)$, adjetivos deverbais (5,55\%), substantivos deverbais (dois exemplos: mercadeiro, mandadeiro, 3,7\%), adjetivos deadverbiais (um exemplo: dianteiro, 1,85\%). Dessas palavras mais recentes, $29,63 \%$ são profissões, mas há outros derivados que possuem o traço [+humano], como solteiro, herdeiro, enquanto um número significativo (12,96\%) tem um traço durativo evidente (parleiro, mentireiro, prazenteiro etc.) ou um valor locativo (moleira, cabeceira, outeiro: 12,96\%), mas apenas dois exemplos de vegetais (azinheira, giesteira: 3,7\%).

No mesmo período, é interessante observar que uma outra fonte que detalhe melhor o que aconteceu nesse período: o dicionário Houaiss, que acusa predomínio do nome de vegetais (60\%) e de profissões (20\%) no séc. IX e X. Para o século XI abonam-se, ao lado dos vegetais $(30,77 \%)$ e das profissões $(23,08 \%)$, sobretudo palavras com valor locativo (38,46\%). No século XII, computam-se $18,51 \%$ de vegetais, $37,04 \%$ de profissões 
(sem falar que aparecem, pela primeira vez, casos afins, associados à função, mas sem o traço [+humano]: falcoeiro, podadeira) e $22,22 \%$ de locativos. No século XIII, num corpus de 117 termos, as profissões somam 44,44\%; os locativos aparecem em 14,53\%; os vegetais, em 9,4\%. Nesse século computam-se ainda adjetivos: 6,84\%, assim como algumas palavras esparsas com o traço [+humano], mas não referentes a profissões (solteiro, herdeiro, companheiro, quinhoeiro) ou palavras sem o traço [+humano], mas com algum valor funcional (coelheiro, grueiro). Pela primeira vez, os valores locativos parecem gerar significados referentes a conjuntos homogêneos (nevoeiro) ou a doenças (pulmoeira).

Parece, portanto, ser possível traçar, preliminarmente, a partir desse corpus medieval, alguns percursos semânticos com referência a -eiro no português:

Etapa I: A função inicial de -eiro era a de um sufixo denominal e relacional, formador de adjetivos. Provavelmente a primeira função do -arius latino seria essa ( $\mathrm{O}>A)$. Encontram-se em latim (Gaffiot, 1934) palavras como abecedarius "relativo ao alfabeto", abietarius "referente ao abeto", acinarius "da uva", beneficiarius "que provém de um benefício", bestiarius "de fera", chartarius "concernente ao papel", denarius "de dez", funerarius "relativo aos funerais". Muitas dessas formas foram reintroduzidas no português sob a forma do sufixo -ário, irmão gêmeo de -eiro. No entanto, o fato de muitas dessas formas serem substantivos hoje em dia decorre de uma mudança funcional já existente no latim. Assim, operarius significava inicialmente "relativo ao trabalho", de modo que se podia falar de homo operarius "pessoa que trabalha" bem como pecus operarium "animal de carga". O uso de operarius como substantivo "trabalhador" coexiste como o uso adjetival, em Cícero. Formam-se, assim, substantivos provenientes de outros substantivos, ou seja $\mathrm{O} \gg \mathrm{O}$. Também denarius, acima citado cedo, se tornou um substantivo.

Etapa Ila: A partir dessa derivação surge o uso de -arius como indicador de profissão, já no período tardio ou na alta Idade Média. Por exemplo, cocinarius "relativo à cozinha" cedo passou a referir-se àquele que trabalha na cozinha, o cozinheiro. A função inicial de criação de adjetivos não deixou de existir, antes estendeu-se também para casos do tipo 
A > A: de primus surge a forma reforçada primarius, de secundus, secundarius; de tertius, tertiarius. Dessa forma, pode-se generalizar que uma função inicial ou um sentido inicial não deixam de existir ao se gerarem funções ou sentidos derivados, antes convivem com eles. A questão se coloca apenas quanto à produtividade, que cai, pois se inicialmente temos $100 \%$ das palavras em -arius com a mesma função, na segunda etapa, essa totalidade é distribuída entre a inicial e a(s) secundárias(s). Uma série de palavras passa indicar profissões: bigarius "condutor de biga", musicarius "fabricante de instrumentos musicais". Daí também surgem scutarius "quem fabrica escudos", caballarius "quem cuida dos cavalos", donde não se derivam com certeza escudeiro e cavaleiro, que têm significados bem distintos. A produtividade de -arius permitiu, em latim, a criação dessas palavras a partir de scutus e de caballus e, da mesma forma, -eiro gerou outras duas, a partir de escudo e cavaleiro. Dizer que scutarius > escudeiro e que caballarius > cavaleiro seria, portanto, no mínimo, uma simplificação. É possível que a regra de formação de palavras atue mais de uma vez ${ }^{20}$.

Etapa IIb: paralelamente à formação de substantivos indicadores de profissões, é possível observar que -arius passou a associar-se com nomes de árvores frutíferas. Apesar de *piraria (derivada de * "arbor piraria") não ser uma forma abonada nos dicionários de latim, dela surgem palavras em várias línguas românicas, mostrando ter uma ampla divulgação no latim (REW 6524: engadino pairer, friulano perár, francês poirier, provençal perier, catalão perera, português pereira). A maioria das línguas não aumentou esse veio. Mesmo o castelhano, diferentemente do português, não fez um uso tão abrangente quanto o português, que, a partir de formas como ameixeira, avelaneira, amendoeira, macieira, nogueira, limoeiro, figueira, parreira, laranjeira, oliveira, pessegueiro ampliou bastante esse léxico a partir do séc. XVI, com o conhecimento de outras frutas: abacateiro, açaizeiro, cajueiro, jabuticabeira, jaqueira, mangabeira etc. Uma generalização desse uso

\footnotetext{
${ }^{20}$ Não é preciso que se escute uma palavra como mochilada para que se tome ciência da sua existência: basta que se reconheça em mochila um objeto com o qual é possível se dar um golpe e o significado de -ada para "golpe", daí também no discurso é possível surgirem formas como apagadorzada, gizada, alicatada sem que haja conhecimento do falante se aquela palavra alguma vez tenha sido empregada. Nesse sentido (e apenas nesse), a produtividade, entendida como quer Aronoff, seria empregada incondicionalmente.
} 
(etapa Ilba) se encontra em algumas outras plantas, não-frutíferas: roseira, espinheiro, palmeira, paineira, por exemplo.

Subgrupos facilmente se formam, assim um grupo proveniente de lla (anotado como etapa Ilaa) seria os gentílicos: brasileiro "proveniente do Brasil", mineiro "nascido em Minas", criando um concorrente para -ense ou -ano, mas de uso inicialmente restrito por indicar "quem trabalhava com pau-brasil" ou "quem trabalhava nas minas". No entanto, hoje em dia, o -eiro gentílico se vê em campineiro, pantaneiro e outros. Também de lla surge uma etapa Ilab com aspecto frequentativo bastante marcado, isto é, "pessoa que (faz algo) muito". Assim, aventureiro não é propriamente uma profissão. Ao longo dos séculos também ao grupo I acrescentaram-se formas do tipo $E>A$, como diante $\rightarrow$ dianteiro, bem como ao grupo II surgem formas do tipo I >> 0: lavar $\rightarrow$ lavadeira (nesse caso, porém, a base é participial, o que possibilita uma forma intermediária lavar $\rightarrow$ lavado $\rightarrow$ lavadeira, ou seja I > A $>>0$ ).

Etapa III: a partir de lla, o sufixo passa a indicar, por meio de uma metáfora sobre a profissão, objetos com determinada função. Assim, da mesma forma que peixeiro é um homem que vende peixes, relojoeiro aquele que conserta relógios, carroceiro quem conduz carroças, também saleiro guarda o sal; açucareiro, o açúcar; manteigueira, a manteiga. Na etapa III, o sufixo passa a designar "objeto que tem a função de guardar (algo)". Daí derivam-se ainda charuteira, alfineteira, cartucheira, cigarreira, paliteiro, cinzeiro, papeleira, prateleira, geladeira, sopeira etc. Em alguns casos, a distinção é contextual, uma vez que chaveiro pode ser tanto a pessoa que trabalha com chaves quanto o objeto que guarda chaves. Um carteiro trabalha com cartas, já uma carteira é um móvel ou uma bolsa onde se guardam cartas (ou seja, papéis ou documentos). Em todos esses casos, o sufixo é isocategórico 0 > 0 .

Subgrupos relacionados com essa etapa são bastante frequentes. Uma etapa interessante (que chamamos etapa IIIa) marca "objetos que servem para (fazer algo)". Nesse caso, há também mudanças heterocategóricas do tipo I > 0: assadeira serve para assar, frigideira serve para frigir. Quando, nesse caso, o sufixo é heterocategórico, então subentende-se um verbo: pulseira serve para (ornamentar) o pulso, banheira serve para 
(tomar) banho, joelheira serve para (proteger) o joelho, mosquiteiro serve para (proteger d)os mosquitos. Em todos esses casos, pode-se dizer que houve uma generalização do uso da etapa III.

Uma etapa IIIb generalizaria também, mas mantendo o valor de "guardar". Nesse caso, não se trata de objetos, mas de "locais onde se guarda (algo)". Saem daí galinheiro, coelheira, chiqueiro entre outros. Praticamente trata-se do mesmo sentido da etapa III, mas em vez de se guardar algo inanimado, guarda-se um animal, por isso não se vê o resultado como um objeto, mas como um local. De Illa pode-se extrair um caso semelhante: banheiro é o "local onde se (toma) banho" e não o "objeto com que se toma banho", como em banheira.

Etapa IV: como um objeto ou um local que guarda algo contém muito desse algo guardado, é possível deduzir daí um sentido de "local em que há muito (algo)". Um formigueiro é um local onde há muitas formigas. O mesmo se pode dizer de vespeiro. Um sentido de coletividade é facilmente depreensível daí, numa variação chamada etapa IVa: berreiro seria uma porção de berros, cabeleira uma grande quantidade de cabelos. Daqui também se deriva uma forma pleonástica: montoeira. Quantidade e intensidade andam juntas no português, como se pode perceber pelo advérbio muito que serve para as duas coisas (diferentemente, por exemplo, do inglês: very, many, much, cf. nota de rodapé no 4); dessa forma, deriva-se um subgrupo (etapa IVaa), observável em poeira para marcar um pó intenso ou em nevoeiro é uma névoa densa. Pertence a esse caso a palavra chuveiro, já mencionada no capítulo $2^{21}$. Da mesma forma, o fato de -eira aparecer em muitos sobrenomes não autoriza uma etapa com essa finalidade, uma vez que cada uma dessas palavras se formou isoladamente: Pereira, Nogueira, Oliveira a partir dos nomes de árvores, Ferreira por referência a topônimos com minas de ferro etc. ${ }^{22}$

\footnotetext{
21 Sincronicamente não é possível dizer que o -eiro de chuveiro tenha o significado de "aparelho" ou coisa do gênero, pois isso não seria de modo algum produtivo (embora alguns sufixos como -or o façam: impressora, computador, lavadora, secadora).

22 Não se quer dizer com isso que não existem sufixos para sobrenomes. Embora hoje improdutivo, o sufixo es formador de patronímicos, foi um caso desses: Nunes, Peres, Soares, Rodrigues, Álvares, Gonçalves entre outros. Novamente é preciso separar o significado do sufixo do significado da palavra derivada.
} 
Etapa V: por fim, de llab é possível derivar um marcador de aspecto frequentativo, associado a uma valoração pejorativa. Assim, pianeiro pode ser quem fabrica pianos, como quem costuma tocar piano e o faz geralmente mal. A transição de um significado descritivo para um valorativo é bastante significativa. O sufixo -eiro marcador de profissões concorre com outros, como o mais antigo -or e com o mais recente -ista (que se generalizou a partir do século XVI). Pode-se afirmar, grosso modo, que profissões mais populares acabaram sendo associadas com -eiro, enquanto outras menos populares a -or ou -ista. Provavelmente advém do preconceito de atribuir as profissões populares a tarefas pouco dignas que tenha advindo o traço de pejoratividade. Essa etapa divide-se em vários tipos: chamemos etapa Va aos "atos característicos de (quem faz algo julgado como mau, desagradável ou ridículo)": bandalheira, ladroeira, choradeira, bebedeira pressupõem um aspecto frequentativo herdado de llab, já asneira, besteira, bobeira não necessariamente. Um segundo tipo importante, chamado etapa $\mathbf{V b}$, indicaria uma "situação física desfavorável" com valor durativo: canseira, leseira, gagueira, cegueira, pasmaceira.

Nas cantigas de Santa Maria, as palavras mais recentes, formadas no Iberoromance ou em alguma língua românicas (principalmente o francês), são associáveis à etapa II (monteiro "caçador", marinheiro, pedreiro, arqueiro, vozeira "advogada", justiceiro, guerreiro, covilheira "camareira", evangelisteiro "clérigo que recebeu as ordens maiores", caleiro "operário dos fornos de cal", falcõeiro "que caça com falcão", mercadeiro "negociante", ovelheiro "pastor de ovelhas", romeiro, peleteiro "quem trabalha com peles", mandadeiro "mensageiro", esmoleiro "que dá esmolas", grueiro "caçador de grou", tendeira "vendedora", despenseira "que trabalha na despensa"), mas há outros derivados referentes a seres humanos, associados à etapa I, como companheiro, solteiro, herdeiro, enquanto um número significativo $(12,96 \%)$ tem um traço frequentativo evidente, associado à etapa llab (parleiro "falador", torticeiro "que comete injustiças", virtudeiro "milagroso", sabedeiro "conhecedor", mentireiro "mentiroso", direitureiro "justo", duradeiro "duradouro", prazenteiro "prazeroso") ou associados a objetos e locais, isto é, à etapa III (carreira "por onde passam os carros", moleira "parte superior da cabeça 
(que é mole nas crianças)", cabeceira, mineira "mina", vidreira "vitral", barreira, tabuleiro, outeiro, fronteira, regueiro "rego d'água", costeira, terronteiro "monte de terra": 12,96\%), mas apenas dois exemplos de vegetais (azinheira, giesteira: 3,7\%). A antiga função da etapa I mostra-se ainda bastante produtiva: dianteiro, fronteiro "próximo", postremeiro "último".

Verifica-se que desde os textos mais antigos, praticamente todas as etapas estavam muito presentes. A falta de representantes da etapa $V$ é, no entanto, significativa. No intervalo que existe entre as Cantigas de Santa Maria e os textos de Gil Vicente, percebese que se avolumou o seu número: canseira, grosseiro, lazeira, mexeriqueiro, todos também abonados mais tarde no dicionário Houaiss (2001), que ainda aponta para ladroeira o séc. XVI, gagueira, choradeira o séc. XVIII, bebedeira, bandalheira, pasmaceira para o séc. XIX, besteira para o séc. XX. Assim, asneira "ato bobo (que lembra o de um asno)" aparece no séc. XVIII, ao contrário de asneiro "referente ao asno, criador de asnos", que é do séc. XIII. 


\section{UMA CRONOLOGIA DO SUFIXO -EIRO(A)(S) EM PORTUGUÊS}

O capítulo anterior nos evidencia que quaisquer datas que assumamos formarão apenas um modelo preliminar. Há muito que se fazer na questão das datações dos termini a quo. Não são datadas muitas palavras. Tampouco se preocupou em investigar as datações das acepções: choradeira na acepção de "mulher que chora muito" e na de "choro constante" certamente apareceram em etapas de produtividade distintas.

Quando dois signos dispõem de grande intersecção de significado e significantes idênticos, dizemos que estamos diante de diferentes acepções. Quando nos mesmos signos, os significantes são parcialmente parecidos, dizemos que estamos diante de variantes. Quando, porém, são totalmente diferentes, trata-se de sinônimos. No caso dos sufixos, os termos utilizados para os três casos normalmente são "núcleos semânticos", "alomorfes" e "elementos concorrentes". Esses fenômenos costumam fazer parte de um continuum que tem a ver pura e simplesmente com a questão do significante. $\mathrm{O}$ significado será sempre parcial, pois, caso contrário, teríamos o mesmo signo empregado com uma só acepção (em outras palavras, estaríamos diante de duas ocorrências da mesma palavra ou sufixo).

Do ponto de vista do sistema, concorrentes são dois sufixos com o mesmo significado. Isso ocorre, portanto, com os núcleos semânticos de um dado sufixo e não com o sufixo em sua integralidade. Assim, há palavras terminadas em -eiro que designam árvores frutíferas. Nessa acepção, o sufixo -eiro praticamente não tem concorrentes produtivos. Seus únicos concorrentes são morfemas lexicais ou construções sintáticas: pode-se falar laranjeira ou pé de laranja. Já o sufixo -eiro designando profissões tem outros concorrentes igualmente fortes, por serem produtivos: -ista e -or. Do mesmo modo que não existem sinônimos perfeitos entre palavras, não há, vendo o conjunto como um todo, sinônimos perfeitos de sufixos, de sorte que formas como pianista e pianeiro significam coisas distintas. Por fim o -eiro para gentílico é um fraco concorrente para outros sufixos mais produtivos como-ano e-ense. 
A experiência demonstra que o trabalho com corpora ${ }^{23}$, além de ingrato e demorado, é pouco representativo. Mesmo em conjuntos colossais de textos, como os da internet, acessíveis atualmente por buscadores como www.google.com.br, os resultados não representam a realidade (a já mencionada huge chart bloomfieldiana). O Dicionário Houaiss, por exemplo, é um corpus de tamanho bastante extenso, com seus 193234 verbetes (contando homônimos). Pesquisas em buscadores são também fontes bastante exaustivas para tira-teimas, mas não são o sistema linguístico almejado nas descrições. A prolificidade de -eiro e de suas flexões (-eira, -eiros, -eiras) no dicionário Houaiss conta com 4482 verbetes (sem contarmos os homônimos e excluindo o próprio sufixo e sete alomorfes) terminadas nessa sequência. Computando-se os homônimos, o número aumenta para 4673. Para aprimorar esse conjunto de dados, fazem-se as exclusões citadas no capítulo $4^{24}$ e chega-se ao número de 3718 ocorrências $(79,6 \%)$, que forma uma base de sequências virtualmente sufixadas sem elementos desnecessários. É grande o número de palavras que fogem à nossa experiência, que jamais empregamos ou vimos escritas. Excluídos os casos das sequências virtualmente sufixadas, 28 (0,75\%), o número de

${ }^{23}$ É sabido que os corpora têm várias restrições:

- Os corpora revelam apenas a língua escrita, o que é parcial, mas não errôneo, nem inútil. A língua falada se perde, a não ser que se levem em conta corpora de língua falada espontâneos, só possíveis de um século para cá.

- Os corpora são textos que têm orientações temáticas, sendo possível que determinadas palavras apareçam com muita freqüência em alguns e muito raramente em outros, sendo que isso nada teria a ver com a freqüência de uso na fala.

- Os corpora de textos antigos escondem a questão da variação sociolingüística.

- Os corpora têm uma relação diferenciada para com a neologia.

${ }^{24}$ a saber, excluem-se:

- O próprio verbete para o sufixo e os seus alomorfes, a saber: -eira, -zeiro, -leiro, -deiro, neira, -oeira, -ueiro;

- As justaposições, como atum-verdadeiro, bicho-barbeiro, ou seja, que têm elementos repetidos no corpus. Esse critério não é automático (manipulável, por exemplo, por uma regra de presença ou ausência de hífen), pois alguns casos como roupa-velheiro, sãojoaneira não são casos de justaposição, mas de derivações sobre uma base justaposta;

- As composições óbvias (como bioengenheiro, aeropioneiro) e prefixações facilmente parafraseáveis (antibrasileiro, antecordilheira, mas não desempenadeira, despenhadeiro);

- As justaposições por reduplicação (cheira-cheira);

- As variantes, ortográficas e regionais da mesma palavra (samaumeira, pois já há sumaumeira);

- Os pseudo-homônimos ou seja, homônimos provenientes de reduções de justaposições (cortadeira, como redução de formiga-cortadeira). 
sequências baixa para 3690. Além dessas, em 48 palavras (1,3\%) não é possível determinar nenhuma etimologia confiável. Se excluimos essas também, o número baixa para 3642. Dessas, 1495 (41\%) não têm qualquer datação (vide ANEXO).

Dessa forma, chega-se à conclusão que os corpora são insuficientes: o dicionário apresenta palavras demais e os textos, palavras de menos. A neologia, fonte da produtividade, evidentemente pode ter uma abonação num dicionário, mas arduamente figura em corpora de textos, menos ainda numa lista de palavras mais frequentes, pois neologismos são, por definição, palavras raras. Assim, em todo o inventário do dicionário Houaiss de palavras conhecidas e derivadas com o sufixo -eiro, as paráfrases mais prolíficas são:

\section{(A) $X]_{\text {eiro }}=$ que é de $X$}

$X$ é um substantivo e o resultado um substantivo ou um adjetivo. Esse caso já traz sua produtividade desde o latim (por exemplo, coquinarius significa "que é da cozinha") no entanto, aparece nessa lista apenas no século XIII em palavras como: herdeiro (do latim hereditarius), guerreiro, verdadeiro (XIII), costumeiro (XIV), passageiro (via francês), lisonjeiro, costeiro (XV), aduaneiro (XVII), pesqueiro, hospedeiro (XVIII), cafeeiro, hoteleiro, manufatureiro, financeiro, traiçoeiro, almiscareiro, rotineiro (XIX), usineiro, brigadeiro (XX). Sem datação: canavieiro. A palavra veleiro (XV) é provavelmente uma substantivização dessa acepção.

(B) $(X)]_{\text {eiro }}=$ pessoa que $V X$

Nesses casos, X, quando não é base opaca (marcada entre parênteses), é um substantivo e o resultado, um ser humano ou um adjetivo. No lugar de $\mathrm{V}$ postula-se um verbo como "vender", "trabalhar com", "consertar", "cuidar de", "conduzir", "entregar", "fabricar", "negociar", "tocar", "usar" ou o mero "fazer". Também um dos casos mais antigos, remonta ao latim (latim caballarius = aquele que cuida de cavalos), 
as palavras remontam aos primórdios da documentação portuguesa: carvoeiro (IX), barqueiro (X), vaqueiro (XI), sapateiro (XII), escudeiro, mensageiro, jornaleiro, enfermeiro, tropeiro, pedreiro, tesoureiro, peixeiro, justiceiro, companheiro, arteiro (XIII), feiticeiro, ferreiro, carpinteiro (XIV), tapeceiro, torneiro, tintureiro, costureiro $(\mathrm{XV})$, cocheiro, marceneiro, livreiro, confeiteiro, casamenteiro, porqueiro, fiandeira $(\mathrm{XVI})$, relojoeiro, carteiro, merendeira, passarinheiro, bandoleiro, milagreiro (XVII), violeiro, carpideira (XVIII), carroceiro, jangadeiro, curandeiro, vidraceiro, joalheiro, chapeleiro, fuzileiro, titereiro, cabeleireiro, toureiro, leiteiro (XIX), muambeiro, bombeiro, barbeiro, boiadeiro, cervejeiro, funileiro, leiloeiro, garimpeiro, tropeiro, madeireiro, bilheteiro, carreteiro, ferramenteiro, perueiro, rendeira, sinaleiro (por metáfora aplicada ao semáforo), faxineiro, quituteiro (XIX), borracheiro, bicheiro, doleiro, verdureiro, charreteiro, sorveteiro, roqueiro, motoqueiro, lixeiro, pistoleiro, macumbeiro, seresteiro (XX). Sem datação: caminhoneiro, piqueteiro, marqueteiro, buraqueiro, catimbozeiro, grafiteiro, pipoqueiro, doceira.

Em carniceiro, o sentido mais comum no português brasileiro não é o de profissão que veio antes (XIII). Também padeiro (XIII) necessita de informação diacrônica para justificar a semi-opacidade da base. Em carpinteiro (XIV), palavra que remonta ao latim, a opacidade da base é total. Interessante é o caso de barateiro (XVI) que pediria uma paráfrase do tipo "pessoa que vende (tudo) X".

(C) $V]_{\text {eiro }}=$ pessoa que $V$ (com frequência)

Também é possível uma situação de agentivos deverbais intensificados mais tardios: parideira (XVIII), namoradeiro (XIX), dadeira, faladeira (sem datação). O resultado vale também no caso de animais: poedeira (XVIII), armadeira (sem datação), plantas: trepadeira (XVIII) e dormideira (sem datação), e de seres não vivos: corredeira (XIX). Apenas a frequência não é parafraseável em agentivos deverbais não-intensificados como: lavadeira (XIX) e arrumadeira (XX). 
(D) $X]_{\text {eiro }}=$ pessoa que (gosta de) $\mathrm{VX}$

A partir do arteiro (XII), desenvolveram-se, para um V variável ("fazer", "ver", "dar", "ir em" etc.), palavras que tem valor muitas vezes negativo ou tonalidade familiar com uma certa modalização relativa à tendência do agente: mexeriqueiro (XV), noveleiro, aventureiro (XVI), trapaceiro, lambisqueiro, embusteiro (XVII), galhofeiro, bisbilhoteiro, caloteiro, festeiro (XVIII), cachaceiro, pagodeiro, beijoqueiro, arruaceiro, politiqueiro, ordeiro, novidadeiro, taberneiro (XIX), bagunceiro, cambalacheiro, biscateiro, barraqueiro, batuqueiro, loroteiro, fofoqueiro, encrenqueiro, maconheiro, metaleiro $(\mathrm{XX})$, forrozeiro, punheteiro, mochileiro, baderneiro, mutreteiro, trambiqueiro, fuxiqueiro, truqueiro (sem datação).

(E) $X]_{\text {eiro }}=$ pessoa que provém de $X$

$X$ é um lugar e o resultado, um ser humano ou um adjetivo. Provavelmente tem origem agentiva: mineiro, brasileiro, campineiro (XVIII), pantaneiro (XX).

(F) $X]_{\text {eiro }}=$ árvore que produz $X$

Também remonta ao latim, de modo que a partir de uma forma * piraria = árvore de pêras remonta-se a muitas línguas românicas (cf. REW 6524: engadino pairer, friulano perar, francês poirier, provençal perier, catalão perera). De fato, no corpus, pereira é mais antigo (IX), seguido de castanheiro, loureiro, figueira, nogueira (X), pinheiro, espinheiro, pimenteira (XI), macieira, avelaneira, laranjeira (XIII), oliveira, ameixeira $(\mathrm{XIV})$, pessegueiro, amoreira, roseira (XV), marmeleiro, cajueiro, mangabeira, cerejeira, limeira, bananeira, mangueira, jaqueira (XVI), limoeiro, jenipapeiro, coqueiro, goiabeira, tamareira, aboboreira, pitangueira (XVII), algodoeiro, mamoeiro, sabugueiro, ingazeiro, jabuticabeira (XVIII), tamarindeiro, abacateiro, tomateiro, 
cafezeiro, paineira, romãzeira (XIX), caquizeiro (XX). Sem datas: juazeiro, chuchuzeiro, castanheira, caramboleira.

Necessário é observar que nem sempre os antecedentes são frutos: loureiro produz as folhas de louro, roseira produz as flores chamadas rosa, não é fruto também o ancedente espinho de espinheiro e também em pimenteira, o antecedente pimenta apenas é um fruto tecnicamente, pois os falantes não o vêem necessariamente assim.

(G) $X]_{\text {eiro }}=$ que é $X$

Esse curioso caso de redundância apenas estende o significado do antecedente, que pertence normalmente da classe dos adjetivos, de modo a não modificar ou apenas modificar ligeiramente, por metaforização, o seu sentido. São os casos: certeiro (XIII), grosseiro $(\mathrm{XVI})$, raseiro $(\mathrm{XIX})$, canhoteiro $(\mathrm{XX})$.

(H) $X]_{\text {eiro }}=$ pessoa que $V$ em $X$ :

Nesses casos, X é sempre um lugar. O V normalmente se entende como "trabalhar", mas pode simplesmente ser "agir", como em guerrilheiro (XIX), "viver", como em roceiro (XVI), sem datações: corticeiro, maloqueiro. Esse sentido aparece sob a forma mais antiga, nessa lista, em fazendeiro (XII). Tem também os sentido relacional e agentivo, mas é possível interpretá-lo não só como "que é da fazenda" ou "que lida com fazenda", mas "que trabalha na fazenda" ou "que tem a posse de fazenda", sentidos aparentemente derivados. Origina-se, pelo visto, do sentido relacional e agentivo: o latim portarius transformou-se em porteiro; operarius, em obreiro (datadas em português no século XIII). Outros casos: marinheiro, caseiro, granjeiro (XIII), cozinheiro (desde o latim), chaveiro, carcereiro (XIV, do latim medieval), camareira $(\mathrm{XV})$, mineiro, banqueiro $(\mathrm{XVI})$, jardineiro (XVII), quitandeiro, açougueiro (XIX), cabineiro, goleiro (XX). 
(I) $X]_{\text {eiro }}=$ pessoa que possui $X$ :

Os casos de fazendeiro, granjeiro, banqueiro, quitandeiro aparentemente seguiram o mesmo rumo, transformando-se em possessivos. Um caso interessante é o de hospitaleiro (XIII), que seria o dono de um hospital, no sentido antigo de "casa de hóspedes" (cf. catalão hostal, francês hôtel) e que derivou o sentido usual de hoje em dia. Talvez daqui saia o caso de colhereiro (XVIII) e uma paráfrase do tipo "que tem X" justificaria o nome da ave cujo bico se parece com uma colher.

(J) $X]_{\text {eiro }}=$ que está em $X$

Faz parte desse tipo traseira, dianteiro (XIII), rabeira (XVII). Para pessoas: prisioneiro (XIV, decalcando francês), para objetos: cueiro (XV), pulseira (XVII) e cabeceira (sem datação). Talvez as doenças denominadas unheiro (XVIII), boqueira (XIX) estejam relacionadas como essa acepção.

(K) $X]_{\text {eiro }}=$ objeto em que se $V X$

Derivado do -eiro relacional e do -eiro agentivo, aparece em baleeiro (XIII) "que é de baleia", com restrição para "navio em que se pesca baleias". Além de "pescar", outros V são: "fazer": cuscuzeira (XVI), churrasqueira, coqueteleira (XX); "ferver": chocolateira, cafeteira (XVIII), leiteira (XIX), chaleira (XX); "tomar" banheira (XIX); "transportar": petroleiro, negreiro (XIX) ou "guardar": açucareiro (XVI), fruteira (XVII), saleiro, alfineteiro, paliteiro, cinzeiro, cartucheira, cristaleira, confeiteira, carteira (XVIIII), camiseiro, saladeira, farinheira, papeleira, cigarreira, alfineteira, saboneteira, sorveteira, compoteira, charuteira, manteigueira (XIX), lixeira (XX), lancheira, iogurteira, sapateira (sem datação). 
(L) $V]_{\text {eiro }}=$ objeto em que se $\mathrm{V}$

As formas deverbais da lista são todas femininas e tendem desde muito cedo a um molde fônico em -deira: engomadeira (XVIII), namoradeira, escarradeira, espreguiçadeira, chocadeira (XIX), penteadeira, geladeira (XX), incubadeira (sem datação). Um caso um pouco distinto é atoleiro (XV).

(M) $X]_{\text {eiro }}=$ objeto em que há $X$

Alguns exemplos: cancioneiro $(\mathrm{XV})$, fogareiro, braseiro $(\mathrm{XVI})$, romanceiro (XIX, via espanhol). Sem datação: chaveiro. Como resultado adjetivo surge bosteiro (XX).

(N) $X]_{\text {eiro }}=$ lugar em que se $V X$

Os casos mais representativos são os do tipo "em que se guarda $(X)^{\text {": }}$ galinheiro (XV), chiqueiro (XVI, com base opaca), mangueira (XX, do espanhol, com base opaca).

(O) $X]_{\text {eiro }}=$ objeto com que se $V X$

Derivado do -eiro relacional e do -eiro agentivo, aparece em com $\mathrm{V}$ interpretado como "proteger": joelheira (XIII, "objeto com que se protege o joelho"), focinheira $(\mathrm{XVII})$, tornozeleira, munhequeira (XX), caneleira, cotoveleira (sem datação) ou "lançar": bombardeiro (XV) ou "captura": ratoeira (XVII) ou "retirar": escumadeira (XVI). Curioso é o caso de mosquiteiro (XVIII) cuja paráfrase é um objeto com que se $V$ de $X$. Também pode haver um deslocamento do resultado para seres animados e o verbo "caçar": perdigueiro ("cão com que se caçam perdizes").

(P) $V]_{\text {eiro }}=$ objeto com que se $\mathrm{V}$ 
As formas deverbais da lista são todas femininas e tendem desde muito cedo a um molde fônico em -deira: batedeira, frigideira (XIV), nadadeira, mamadeira, enceradeira, atiradeira, britadeira (XX). Sem datações são: desempenadeira, torradeira, furadeira, assadeira e tostadeira. Uma pequena mudança de sentido pode se ver em nadadeira que tem como resultado não só um objeto mas uma parte do corpo. Também uma brincadeira (XIX) é um ato e não um objeto. Observe que o caso de pesqueiro, já mencionado como relacional pressupõe em sua base ou um nome pesca ou um verbo pescar (não-particípio) como antecedente, da mesma forma que chuteira (XX) pode vir de chute ou de chutar não-participial.

(Q) $X]_{\text {eiro }}$ lugar em que há muito $X$

Entre os mais antigos: pedreira (XIII), formigueiro, vespeiro (XVI), bicheira (XVIII). Outros exemplos sem datação: cupinzeiro, pulgueiro e puteiro.

(R) $X]_{\text {eiro }}=$ lugar em que há $X$

Exemplos: letreiro (XIV) e oveira (sem datação).

(S) $X]_{\text {eiro }}=$ muito $X$

Exemplos: cabeleira (XV), barreira (XVI), sangueira (XVIII), poeira, catarreira, buraqueira, barulheira, chiadeira (XIX), desgraceira, sujeira, biboqueira (XX). Aqui talvez entre nojeira (sem datação). A palavra sujeira é deadjetival (paráfrase mais adequada: "algo muito X"). Trabalheira não tem datação mas devem ser posteriores ao século XVI. Babeira no sentido de "muita baba" não está dicionarizada, nem datada. Esse núcleo semântico costuma apresentar conotação pejorativa. Outras palavras sem datação: bobageira, ciumeira, piolheira, desgrameira, sovaqueira. 
(T) $X]_{\text {eiro }}=$ pessoa que tem muito $X$

Exemplos: interesseiro (XVI), peidorreiro (XVIII), fricoteiro (XX). Também perdigoteiro (sem datação).

(U) $X]_{\text {eiro }}=X$ intenso.

Os melhores exemplos são: nevoeiro (XIII?, com mais certeza século XV), aguaceiro $(\mathrm{XVI})$, fumaceira, preguiceira (XIX). Desde muito cedo, alguns moldes fônicos em ceiro/a, -alheira começam a surgir.

(V) $V]_{\text {eiro }}=$ estado em que algo se $V$ intensamente

Melhores exemplos: quebradeira (XIX). Sem base participial se encontram: roubalheira, berreiro (XIX) que permitem interpretação como intensidade ${ }^{1}$ ou como intensidade ${ }^{2}$ (de roubo ou de roubar, de berro ou de berrar).

(W) $V]_{\text {eiro }}=$ estado em que uma pessoa $V$ intensamente

Melhores exemplos: bebedeira (XIX), tremedeira (XX). Sem datação: suadeira, gemedeira,

(X) $X]_{\text {eiro }}=$ estado em que uma pessoa é $X$

Melhores exemplos: cegueira (XV), gagueira (XVIII).

(Y) $X]_{\text {eiro }}=$ ato típico de $X$

Exemplos: ladroeira $(\mathrm{XVI})$, asneira, tonteira (XVIII), besteira $(\mathrm{XX})$, bobeira, doideira 
(sem datação).

Para se estabelecer uma genealogia dos significados de -eiro, provenientes dos núcleos semânticos elencados acima é preciso observar que, ao fim e ao cabo, uma palavra do tipo $\mathrm{X}]_{\text {eiro }}$ pode ser um adjetivo ou um substantivo designador de uma pessoa, um animal, uma planta, um objeto, um lugar, uma coleção, um estado ou um ato.

A base também está associada ao significado do resultado por um antecedente modificado de forma existencial, locativa, intensiva ou circunstancial (relativa, proveniência). A base pode também remeter a um antecedente que implique ações. Abstrair todos esses detalhes é algo demasiadamente complexo.

No entanto, século a século, podemos flagrar o que pode ter acontecido com o significado do sufixo:

(a) Antes do século XIII

As escassas informações acerca do sufixo -eiro mostram que ele possuía inicialmente os núcleos semânticos $b, f, h$. O núcleo $d$ não é muito evidente. Pelo latim arius, sabe-se que $a$ também estava presente nessa época. 0 sufixo, então, nesse período apenas designava adjetivos, nomes de árvores e profissões. São desse período também palavras como fevereiro, salgueiro $(\mathrm{X})$, celeiro $(\mathrm{XI})$, pardieiro, cabreiro e barreira (XII) de raízes opacas.

(b) Século XIII

Neste século, acrescentam-se os núcleos semânticos $g, j, o$ e $q$, muitos talvez presentes no período anterior, sobretudo o uso redundante. Aparecem então adjetivos locativos, indicações de objetos com que se faz algo e lugares em que há abundância de 
algo. Aparecem documentadas várias palavras problemáticas (muitas herdadas do latim) como: primeiro, terceiro, cordeiro, ligeiro, dinheiro, poleiro, janeiro, padroeiro, matreiro, solteiro, caldeira, palmeira, maneira, peneira, fogueira e caveira.

\section{(c) Século XIV}

Neste século, dá início à produção dos núcleos semânticos $p, r$ e a julgar pelos dados anteriores, generalizam-se ainda mais os lugares em que há algo e os objetos com que se faz algo. Aparecem nos documentos formas como: estalajadeiro, candeeiro, estrangeiro, estaleiro, moleiro, cativeiro, estribeira, bandeira, esterqueira.

(d) Século XV

Neste século, começam grandes inovações: surge a forma modalizada do agentivo (d) e reforçam-se os locativos $(m, n)$, destaca-se a questão da intensidade $(s, u)$ e aparecem palavras marcando estado $(x)$. São casos de estudo as seguintes palavras que surgem nesse século: ribeiro, faceiro, canteiro, ladeira, rameira, alcoviteira.

(d) Séculos XVI e XVII

As grandes novidades do séc. XVI são as palavras que denotam pessoas que têm muito algo e os atos típicos, além de objetos em que se faz algo (respectivamente $t, y$ e $k$ ). No século XVI ocorrem palavras como: despenhadeiro, ribanceira, coceira, fileira, coleira, caganeira, cachoeira, toupeira, cantareira, parreira, canseira, tranqueira, engenheiro, tabuleiro, terreiro, sorrateiro, ponteiro, escoteiro, morteiro, rasteiro, forasteiro, corriqueiro. No século XVII: carabineiro, gazeteiro, roteiro, viveiro, cordilheira, frieira, torneira, lareira, carreira e viseira, todas palavras que orbitam em torno dos núcleos semânticos definidos e que apresentam dificuldades de análise ou potencialidades abortadas. 
(e) Século XVIII

Aparecem nesse século os gentílicos $(e)$ e as pessoas que costumam fazer algo com frequência $(c)$. Também se generalizam os objetos em que se faz algo (I). São palavras importantes para análise do século: desfiladeiro, cavaleiro, carneiro, vinhateiro, fogueteiro, cruzeiro, bagaceira, varejeira, prateleira.

\section{(f) Século XIX}

A grande novidade desse século são os estados em que algo ou alguém faz algo intensamente $(v, w)$. Precisam de análise mais amiudada palavras como: cangaceiro, farofeiro, banheiro, paneleiro, faroleiro, pioneiro, travesseiro, regateiro, zombeteiro, domingueiro, seringueiro, isqueiro, ribeira, bandalheira, borralheira, geleira, soleira, quaresmeira, clareira, lapiseira, baboseira, mangueira, seringueira, biqueira.

\section{g) Século XX}

Não há nenhum novo núcleo semântico determinado por -eiro, embora não faltem palavras complexas nesse período: ficheiro, rancheiro, motorneiro, eleitoreiro, bueiro, pistoleira, jardineira, montoeira, mangueira, zonzeira. Mais complexos são termos sem datação alguma e com dificuldades na estrutura: cavalheiro, cobreiro, saideira, caranguejeira, madeireira, leseira, empreiteira, espiriteira, rasteira, lambuzeira. Com base nesses dados é possível imaginar o seguinte esquema de derivações dos núcleos semânticos: 


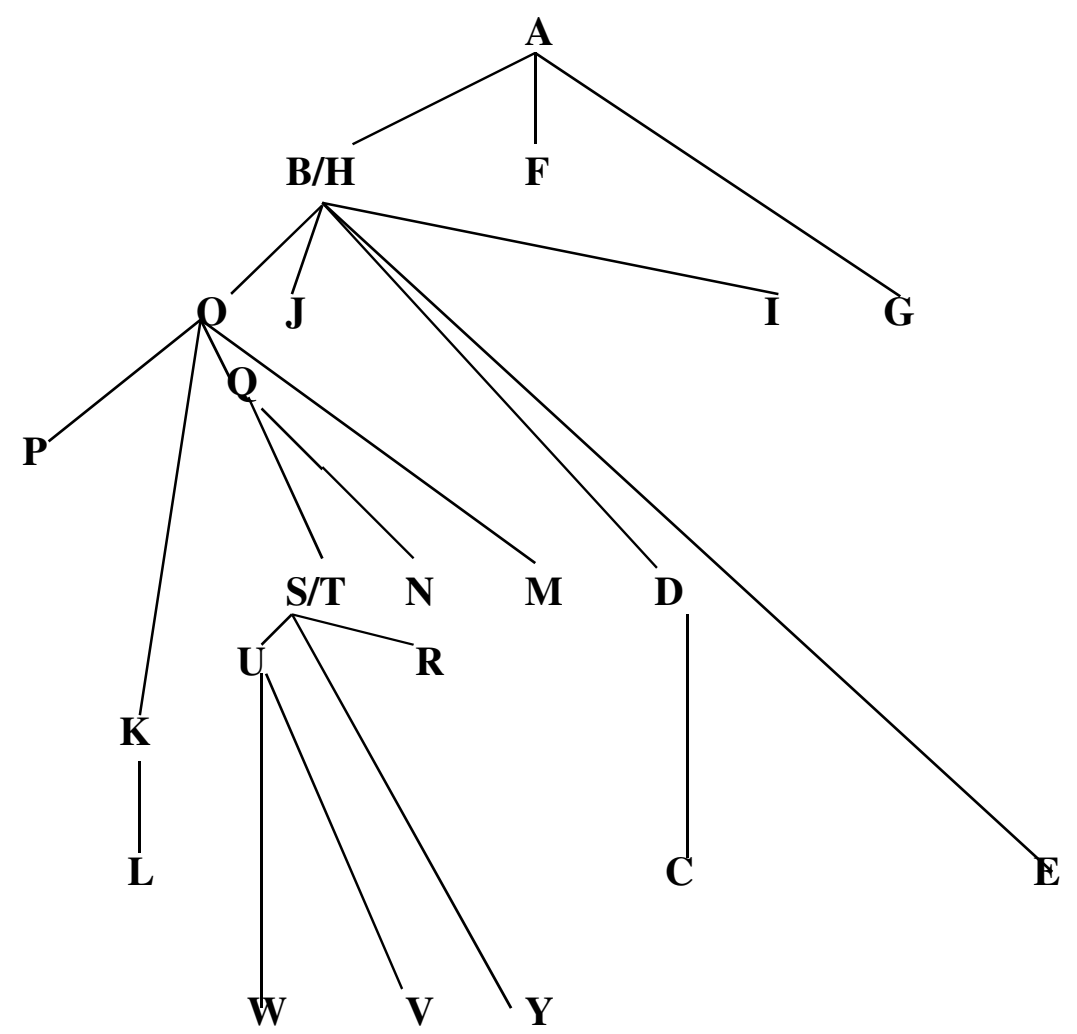

Latim

Período romance

Século XIII

Século XIV

Século XV

Século XVI/XVII

Século XVIII

Século XIX

Gráfico 7 - Transformações do sufixo -eiro.

Paráfrases :

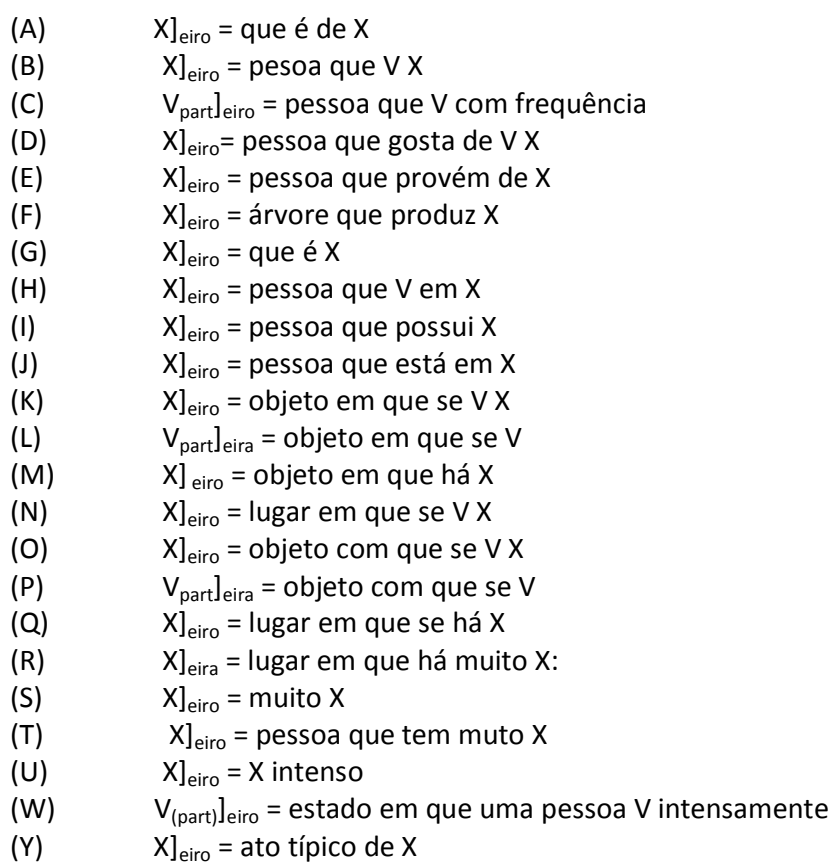


No esquema geral da árvore genealógica dos núcleos semânticos estamos longe de afirmar que sua interrelação seja monocausal e há vários dados que provam de fato não sê-lo, mas só o estudo dos elementos não facilmente parafraseáveis, bem como de outros elementos da língua não-usual e não-atual podem explicitar quão extensa é a zona em que orbitam os elementos não-prototípicos que não se fundamentam as paráfrases dos núcleos semânticos. Nesse sentido, a pesquisa em dicionários antigos se revela imprescindível para alterar a proposta genealógica acima. Num segundo passo, a consulta em corpora diacronicamente organizados poderá corroborar ou aprimorar esse mesmo esquema geral. 


\section{CONCLUSÃO}

Aprendemos que sapato é uma palavra simples e sapateiro, derivada, assim como nos parece relativamente clara a distinção entre os substantivos abstratos e concretos. A partir de 120 palavras formadas com o sufixo -eiro, coletadas num corpus de textos ${ }^{25}$, num teste informal, um informante de nível superior, doutor em Letras, afirmou não conseguir entender ou detectar a base em 38 casos (31,7\%). Em alguns casos, a derivação assume posições interessantes: afirmou que gelo $\rightarrow$ geladeira. De fato, a memória depende da frequência usual e, para o informante, gelo é mais associável, por estar mais rapidamente presente na memória, do que gelar, verbo defendido, por exemplo, por um linguista que postularia a derivação deverbal a partir do particípio gelado para esses casos em -eiro. Outras situações que causaram dúvida no informante foram as seguintes derivações: engenho $\rightarrow$ engenheiro, cruz $\rightarrow$ cruzeiro, enfermo $\rightarrow$ enfermeiro, carta $\rightarrow$ carteira, barro $\rightarrow$ barreira, solto $\rightarrow$ solteiro, cocho $\rightarrow$ cocheiro, travessa $\rightarrow$ travesseiro, tesoura $\rightarrow$ tesoureiro, carne $\rightarrow$ carneiro, caldo $\rightarrow$ caldeira, trinchar $\rightarrow$ trincheira. De fato, outros informantes com certeza não teriam dúvidas em alguns (como enfermo $\rightarrow$ enfermeiro), ou não veriam casos de derivação em outros (como em cruzeiro), ou proporiam outras palavras simples em outros (talvez coche $\rightarrow$ cocheiro, tesouro $\rightarrow$ tesoureiro). Subjetivismos semelhantes se instauram em propostas teóricas, em que testes semelhantes são aplicados a si mesmo. Prosseguindo nosso teste, o informante encontrou ainda situações, que apresentava como palavras simples outras palavras derivadas ou ainda palavras que necessitariam muitas mudanças fonéticas para justificar a derivação: companhia $\rightarrow$ companheiro, três $\rightarrow$ terceiro, mar $\rightarrow$ marinheiro, carpir $\rightarrow$ carpinteiro, brigar $\rightarrow$ brigadeiro, correr $\rightarrow$ carreira, cheirar $\rightarrow$ cheiro, rio $\rightarrow$ ribeiro, beirada $\rightarrow$ beira, cavalheirismo $\rightarrow$ cavalheiro, herança $\rightarrow$ herdeiro, palmito $\rightarrow$ palmeira, par $\rightarrow$ parceiro, ribeirão $\rightarrow$ ribeira, frei $\rightarrow$ freira. Isso mostra que a palavra-base que vem para a

\footnotetext{
${ }^{25}$ Essas 120 palavras em -eiro foram retiradas, no ano de 2006, de um corpus elaborada pelo prof. Dr. Waldemar Ferreira Netto, da USP, que gentilmente cedeu cópia de uma lista por ele preparada, em que constavam as 14002 palavras mais freqüentes (com número igual ou maior a 100 ocorrências) extraídas a partir de um imenso corpus de textos, dos mais diversos, por ele coletados e digitados (o número total de ocorrência dessas palavras somadas remontava, na época, a 15.958.907).
} 
consciência do falante nativo é a mais proeminente na memória, definida, entre outras coisas, com base em sua usualidade.

É sabido que as palavras estão inseridas num discurso, que, por sua vez, tem, como dito, uma dimensão histórica e outra sociolinguística. O termo "frequência", que define a usualidade, está associado, porém, à dimensão sociolinguística, e é polissêmico:

(a) Subjetivamente, uma palavra é "frequente" quando é conhecida ou supostamente conhecida por muitos ou todos os falantes de uma determinada língua. Isso se baseia preponderantemente na experiência individual: eu posso achar que verdolengo seja uma palavra conhecida por qualquer pessoa, mas pequenos testes comprovariam se estou certo ou errado. Como é impossível rastrear os atos de fala, palavras efetivamente conhecidas por todos se impõem para a formação da koiné no caso de fragmentação dialetal (como ocorre atualmente com o alemão suíço), neutralizando traços "excessivamente marcados", mas não é muito diferente nos casos de menor fragmentação dialetal, como no Português Brasileiro, apenas muito mais sutil. Em vez de "frequência", essa característica subjetivamente detectada seria mais bem denominada como usualidade;

(b) Objetivamente, uma palavra é "frequente" se, baseando-nos em corpora, constatarmos que aparece muitas vezes. Essa frequência absoluta é normalmente artificial e variável, mas tem a vantagem de não ser impressionista. Continuemos a chamá-la de frequência;

(c) Também objetivamente, um corpus que separasse seus textos por meio de uma tipologia (hoje os critérios são ainda muito distintos), constataria que algumas palavras ocorrem em todos os tipos de texto numa dada língua (os artigos e as preposições, por exemplo), enquanto outras apareceriam frequentemente em muitos tipos, outras já estariam restritas a um determinado tipo de texto ou ainda outras seriam raras, aparecendo em alguns ou em todos os textos. Esse trânsito intertextual de algumas palavras poderia permitir que as denominássemos de "frequentes", mas estamos diante de um outro comportamento, mais interessante, embora ainda indisponível, para as afirmações da Linguística. Preferimos chamar essa característica de pantextualidade. 
Igualmente etiquetas dadas a algumas palavras, problema comum dos lexicógrafos, que precisam chamá-las de familiares, populares, chulas, regionais, poéticas, arcaicas entre outros rótulos, estão associadas ao problema da tipologia textual, uma vez que se percebe, pela intuição sobre sua frequência usual, que essas palavras não têm frequência pantextual. O problema da frequência só será resolvido quando se houver uniformidade na questão tipológica dos textos. Sem dados seguros e objetivos sobre a frequência das palavras, dificilmente se poderá criar regras seguras para a derivação, antes se prosseguirá com o uso de regras tradicionais como a da primititividade do infinitivo.

Sabemos que o português dispõe de um sufixo -eiro/-eira, que possui, inclusive uma boa produtividade. Seria, portanto, imprescindível o conhecimento diacrônico, para segmentar esse sufixo? Responderemos isso de uma forma prática. Num outro corpus pesquisado em $2007^{26}$, encontraram-se 372 ocorrências de nomes que continham a sequência -eir-, que se distribuíam em 77 formas flexionadas, das quais 65 vocábulos eram seguidos de vogal temática (outros eram seguidos pelos sufixos -inh-, -al ou de -mente). Desses, extraíram-se 44 verbetes. Ainda não devemos falar de "sufixo", mas de "sequência". Se excluímos as palavras que não se justificam nem sincronica- nem diacronicamente (cadeira, feira, inteiro, madeira), a lista abaixa para 40 vocábulos e 332 ocorrências. Assim, a partir dessa nova nova lista, algumas palavras com sequência -eir- só seriam consideradas portadoras do sufixo -eir- por meio de uma análise diacrônica (denarium > dinheiro, januarium > janeiro, riparium > Ribeiro, ${ }^{*}$ manuariam > maneira, primarium > primeiro, *leviarium > francês léger > ligeiro). É importante indicar aqui que, somadas, essas palavras totalizam 148 ocorrências (44,58\%). Outras palavras, segmentáveis sincronicamente, também necessitariam de alguma explicação diacrônica, apesar de suas bases serem mais reconhecíveis por ainda estarem, de alguma forma, presentes na língua atual. Esses casos, que podemos chamar de parafraseáveis a partir de sua base, são dignos de comentários:

\footnotetext{
${ }^{26}$ Trata-se do corpus compartilhado do projeto da Norma Lingüística Urbana Culta composto dos inquéritos em cinco capitais brasileiras (Recife, Salvador, Rio de Janeiro, São Paulo e Porto Alegre), a saber, D2 REC 05, D2 SSA 98, D2 RJ 355, D2 SP 360, D2 POA 291, DID REC 131, DID SSA 231, DID RJ 328, DID SP 234, DID POA 45, EF REC 337, EF SSA 49, EF RJ 379, EF SP 405, EF POA 278.
} 
Em banheiro, é possível reconhecer uma forma banho+eiro, apesar de isso não ser verdadeiro diacronicamente. A palavra foi formada já em latim: balnearium. Em barreira, é também possível reconhecer uma derivação barra+eira, mas a presença dessa palavra em francês barrière sugere que essa forma tenha sido formada no latim vulgar sob uma forma *barrariam. O mesmo se pode pensar de carreira, que não é derivado em português de carroteira, mas vem de um latim vulgar *carraria. Somente com grande abstração o falante pensaria em "carreira" no sentido locativo "local onde passam carros (de boi)", mas as 26 ocorrências apontam para o sentido de "carreira profissional" (que é a sétima acepção no dicionário Houaiss, embora seja a única realmente ativa, a ponto de essa palavra, via francês carrière, ter entrado no inglês career, no alemão Karriere e mesmo no japonês kyaria). Em carteira (2 ocorrências, no sentido de "móvel"), apesar de carta+eira ("carta" no sentido de uma folha de papel) ser uma possível inferência, o sufixo é suspeito porque essa remota associação não se faz de maneira imediata para o falante.

Há os casos em que o radical está opaco, mas há semelhanças com palavras cognatas. De qualquer forma, apesar de suas bases opacas, ninguém negaria que há sufixo -eiro em padeiro e marceneiro (ausentes no supracitado corpus), por causa de associações com outras derivadas, como padaria e marcenaria. No corpus, depreendem-se, neste caso, estrangeiro, que lembra estranho, ou estaleiro, que é associável com estalagem, terceiro lembra ainda que vagamente três, terço, treze, trezentos. Diacronicamente trata-se de dois empréstimos, provindos da língua francesa: étranger e o antigo astelier. Nesses casos, irregularidades fônicas podem ser toleradas no momento da decisão de estarmos diante de um sufixo ou não. Assim, companheiro parece vir de companhia+eiro, mas há uma irregularidade fônica, pois, a julgar assim, deveria ser *companhieiro. Diacronicamente, a palavra vem de companha e não de companhia, que não vem à mente do falante, por ser palavra desusada. O mesmo se pode falar de corriqueiro, associado com correr, mas com uma irregularidade fônica difícil de explicar até mesmo do ponto de vista diacrônico.

Bases desusadas ou em desuso podem interferir no total de ocorrências de um sufixo: frigideira vem de frigir, verbo em desuso, exceto em algumas expressões (no frigir dos ovos). Se o dado etimológico não é usado como critério, pode haver variação no 
cômputo de sequências -eir- como sufixos, se se baseia exclusivamente na memória ou no bom-senso do falante/linguista. O mesmo vale para um agentivo: brigadeiro, que viria de brigada (na verdade, outro empréstimo do francês) para sua única ocorrência, que tem a acepção específica do conhecido doce homônimo. Um outro agentivo pode conduzir a diferentes interpretações, que dependem da atenção ou da memória do falante: engenheiro pode ser interpretado como pelo falante, julgando sua própria língua, como palavra sem sufixo ou como derivada de engenho (outra vez há aqui um empréstimo do francês) e o falante pode entender essa base ou como "talento" ou como "estabelecimento industrial em zona canavieira" (o que seria errôneo pela datação da palavra original francesa, que remonta ao séc. XIV). Outro exemplo de inconstância de postura se pode ver em cruzeiro (23 ocorrências no corpus), com a acepção de "unidade monetária": somente com um pouco de atenção se associaria essa palavra com o Cruzeiro do Sul e, daí, com cruz. Associações falsas do ponto de vista histórico podem ainda ser feitas: solteiro se associa facilmente com solto, quando o étimo aponta para o latim solitarium.

Parece, portanto, que a visibilidade de um sufixo é proporcional à frequência e à diversidade dos usos derivacionais e/ou flexivos que se fazem a partir de sua base, de tal modo que até bases opacas têm sufixos visíveis, como vimos acima. Dito de outra forma, $a$ visibilidade da base, em sua segmentação, não é portanto, condição necessária para se reconhecer uma sequência fônica como sufixo, desde que ela ocorra em outras flexões e/ou outras palavras derivadas e, mais importante, algumas dessas flexões/ derivações sejam muito frequentes. Parece que assim se resolveu tacitamente, ao longo de anos de estruturalismo, o problema bloomfieldiano dos morfemas cranberry.

Se, contudo, excluímos os casos de raízes mais ou menos opacas, a lista de palavras plenamente parafraseáveis diminui drasticamente para 21 vocábulos ( $50 \%$ da lista inicial que tomava por base como palavras portadoras do mesmo sufixo por critérios diacrônicos) ou 90 ocorrências (27,1\%): arrumadeira, besteira, brasileiro, brincadeira, canteiro, fazendeiro, fileira, financeiro, fogueira, grosseiro, jardineira, lancheira, mamadeira, merendeira, mineiro, ordeiro, pinheiro, tesoureiro. tinteiro, usineiro, verdadeiro. Nessas 
não há dúvida que haja derivação, mas impressiona que $3 / 4$ das ocorrências sejam de palavras em que essa consciência derivacional não está muito clara para um falante, que dispõe obviamente apenas do sistema de sua língua em sincronia.

O número de agentivos se torna ainda bastante reduzido. Excluindo brigadeiro (1 ocorrência), por causa do seu uso no corpus, e também engenheiro (10 ocorrências), que teria uma base instrumental "que trabalha usando o engenho", é possível parafrasear os agentivos da lista final da seguinte maneira:

arrumadeira: que arruma (tipo F, base verbal, 1 ocorrência).

fazendeiro: que trabalha na fazenda (tipo F, base locativa, 1 ocorrência)

tesoureiro: que trabalha com o tesouro (tipo F, base instrumental, 13 ocorrências)

usineiro: que trabalha na usina (tipo F, base locativa, 4 ocorrências)

No mencionado corpus, o termo mineiro não é agentivo, mas adjetivo gentílico, merendeira é um instrumento, isto é, não tem o traço [+humano] característico dos agentivos em -eiro, jardineira é um adjetivo substantivado de base relacional (nome de uma iguaria). A palavra ordeiro também pode ser entendida como adjetivo relacional ("que gosta de ordem").

A ocorrência de cada vocábulo é bastante reduzida, de modo que não é possível concluir nada a partir desses números absolutos. É impressionante, no entanto, a frequência de palavras com derivação pouco clara, o que nos faz pensar na sua relativa antiguidade na língua. Como são irregulares, mantêm-se por causa de sua dispersão nos mais diversos tipos de discurso bem como pela sua frequência, que é motivada por fatores extralinguísticos, como os valores sociais. Por outro lado, as formas mais recentes (e no extremo, os neologismos) têm estrutura mais transparente, porém frequência reduzida, a não ser por alguma distorção motivada por ser tópico em discursos específicos.

Parece razoável, pelo acima exposto, não excluir o elemento diacrônico. Assim, o mais natural seria não só entender que -eiro é continuação do sufixo -arius latino, mas também que esse sufixo se define por meio dessa etimologia. Ou seja, um -eiro cuja base 
não seja reconhecível no português, só será um -eiro de fato se provier do latim -arius. 0 fato de a base ser reconhecível se pauta em acidentes históricos: ou a palavra foi derivada muito recentemente ou o antecedente e seu neologismo conseguiram garantir uma alta usualidade. A aceitação dessa hipótese e o consequente amadurecimento dessa ideia esclarece inúmeros casuísmos da morfologia e é a espinha dorsal de toda argumentação desta tese.

De uma certa forma, a reabilitação do elemento histórico também resolve o problema do estabelecimento da palavra-base. É inegável que haja derivação, no entanto, o estudo estritamente sincrônico desse capítulo gramatical se revela, no mínimo, um contra-senso. Se uma palavra $x$ deriva uma palavra $y$, é evidente que $x$ surgiu antes de $y$ e, portanto, há um intervalo de tempo entre $x$ e $y$. As palavras pedra e pedreiro não surgiram ao mesmo tempo, portanto, uma segmentação de morfemas, pura e simplesmente, não dá conta do problema da multiplicidade de significados dos sufixos, nem da presença dos interfixos. Falar de derivação de palavras, sob esse ângulo é falar de diacronia, da mesma forma que não faz sentido falar de hibridismo sob uma ótica estritamente sincrônica. Normalmente, atribui-se a um componente morfológico um conjunto de formações idiossincráticas, que não participam das regras lexicais. Esse conjunto de exceções é, na verdade, uma lista de palavras formadas em outras etapas linguísticas e, às vezes, em outros sistemas: no latim, no latim medieval, no português entrevisto nos textos latinos medievais, no português antigo, no português renascentista etc. para não falarmos de formações não-portuguesas (muitas vezes criadas no francês ou no inglês e aportuguesadas). Observa-se ainda que um sufixo como -arius dispunha de certo significado, produtividade e mudança categorial no latim e foi herdada, ao lado das inovações, no sufixo -eiro. Do ponto de vista diacrônico, não só se pode afirmar apenas que -eiro vem de -arius, mas que -arius e -eiro são a mesma coisa, do mesmo modo que casa é, em grande parte, a mesma coisa que o latim casa, a despeito da generalização semântica ("cabana" $\rightarrow$ "qualquer residência") e da alteração fonética (o -s- intervocálico se teria sonorizado). É contraditório afirmar que a palavra anticoncepcional se tenha formado em português a partir de elementos decomponíveis como anti-, concepc-, -ion- e 
-al quando dados mostram a anterioridade do francês anticoncepcionnel. A palavra portuguesa é datada de 1949, já a francesa é de 1905 (Houaiss, 2001; Rey-Debove \& Rey, 1993). Seria possível imaginar que uma palavra tivesse surgido primeiro no português falado, migrado para o francês e o francês a tivesse registrado antes, mas isso é incomum em formações cultas como essa. Não seria, ademais, coincidência o surgimento de palavras semelhantes em sistemas diferentes como italiano anticoncezionale, catalão anticoncepcional, alemão antikonzeptionell (ao lado do castelhano anticonceptivo e do inglês contraceptive). Essas palavras deveriam ser estudadas separadamente, cada uma em seu sistema ou são a mesma palavra? Retirado o imenso número de palavras formadas pela via erudita desde o surgimento do português (igreja, escola, universidade, especialidades profissionais e tecnológicas, meios de comunicação atuais), sobraria, para muitos sufixos, um número bastante reduzido de palavras realmente formadas em português.

Desse modo, o sufixo -eiro, consoante esta argumentação e de tudo que já foi exposto, estará presente não só em sapateiro, mas também em primeiro: nem a opacidade do radical, nem a multiplicidade semântica do sufixo devem afastar o fato de que o sufixo -arius, produtivo no momento da formação de primarius, se tenha tornado eiro e, trazendo consigo primeiro, formado no latim, tenha servido de base para formação de outras palavras, como sapateiro. Por outro lado, cadeira, madeira, feira ou freira não estão vinculados ao sufixo -arius (pois remeteriam respectivamente aos étimos latinos cathedram, materiam, feriam e ao português freire). Sincronicamente, contudo, reforçam o molde -eiro e não é de todo excluída a sua participação no sistema. Assim, macaxeira não tem nada a ver com -arius, mas por uma coincidência, a palavra tupi tem semelhança com palavras derivadas que indicam "nomes de planta", como roseira, palmeira, mangueira etc., tanto que graficamente um -i- etimológico (raramente pronunciado) foi acrescentado à escrita.

Sufixos não são formas livres, nem são puramente relacionais como o são algumas preposições ou conjunções. Não raro, contudo, os sufixos foram considerados como destituídos de significado, uma vez que há uma certa irregularidade na formação das 
palavras. De sapato deriva-se sapateiro, assim como de sal sai saleiro. Aparentemente nada haveria de comum entre uma coisa e outra e apenas a partir do radical sapat- ou salteríamos uma derivação obscura de atos ou fatos vagamente relacionados. Entretanto, não é incomum o radical encontrar-se opaco. Apesar de carpinteiro e marceneiro terem radicais pouco claros, ninguém negaria que se trata de profissões. Há, por meio dos mesmos elementos, palavras como carpintaria e marcenaria, mas que significa carpint- e marcen- ? Também o sufixo de chiqueiro tem a mesma função do de galinheiro, sem que fique claro ao falante o que quer dizer o radical chic-. A partir desse raciocínio podemos também inferir que é o sufixo que carrega a maior quantidade de significado e isso parece ser confirmado fonologicamente pelo acento tônico. De fato, pedreiro tem a raiz de pedr-, mas um pedreiro não trabalha apenas com pedras, assim como uma leiteira pode servir para ferver água e não leite. O momento da criação do vocábulo, normalmente perdido, envolve também fatores sociolinguísticos de natureza variada. Uma vez criada a palavra, a atuação de metáforas é inevitável.

Observamos para que o método intuitivo da competência do falante nativo é impreciso para auxiliar em problemas básicos como o da segmentação e separação dos falsos prefixos de sequências fônicas homófonas. Estudos que envolvam diacronia e a tipologia textual, sobre a qual se possa falar de uma frequência pantextual, são, por conseguinte, imprescindíveis, sem os quais se poderá cair em uma infinidade de soluções ad hoc. Para a Morfologia Histórica não é o significado total da palavra, nem o mais conhecido na sua etapa atual, como ocorre com a Lexicologia, mas o significado que o sufixo tinha no momento em que um antecedente serviu de base para produzir o neologismo. É necessário algum tipo de reconstrução nesse procedimento, mas os corpora ajudam na maioria das vezes, como tentamos demonstrar. 
ANEXO

Lista de sequências virtualmente sufixadas, separadas por século (não se incluiu a lista das palavras sem datação, por ser muito extensa):

ANTERIORES AO SÉCULO XIII:

$\begin{array}{lll}\text { carvoeiro } & \text { celeiro } & \text { falcoeiro } \\ \text { pereira } & \text { sobreiro } & \text { apeiro } \\ \text { parceiro } & \text { postreiro } & \text { cabreiro } \\ \text { andeiro } & \text { inteiro } & \text { sapateiro } \\ \text { castanheiro } & \text { vaqueiro } & \text { peleteiro } \\ \text { oleiro } & \text { eira } & \text { arteiro } \\ \text { fevereiro } & \text { pimenteira } & \text { esteiro } \\ \text { loureiro } & \text { lagarteira } & \text { besteiro } \\ \text { salgueiro } & \text { regueira } & \text { cesteiro } \\ \text { barqueiro } & \text { ervedeiro } & \text { regueiro } \\ \text { veiro } & \text { rendeiro } & \text { vozeiro } \\ \text { jeira } & \text { fazendeiro } & \text { laceira } \\ \text { cidreira } & \text { lodeiro } & \text { podadeira } \\ \text { nespereira } & \text { palheiro } & \text { cumeeira } \\ \text { figueira } & \text { pardieiro } & \text { feira } \\ \text { nogueira } & \text { homizieiro } & \text { carvalheira } \\ \text { pinheiro } & \text { lameiro } & \text { barreira } \\ \text { espinheiro } & \text { prestameiro } & \text { fronteira } \\ \text { azambujeiro } & \text { vimeiro } & \text { junqueira }\end{array}$


SÉCULO XIII

\begin{tabular}{l} 
braceiro \\
carniceiro \\
justiceiro \\
lanceiro \\
pitanceiro \\
terceiro \\
mercadeiro \\
mandadeiro \\
verdadeiro \\
madeiro \\
padeiro \\
duradeiro \\
moedeiro \\
semideiro \\
bandeiro \\
tendeiro \\
rodeiro \\
herdeiro \\
cordeiro \\
escudeiro \\
baleeiro \\
areeiro \\
correeiro \\
veeiro \\
cacifeiro \\
mensageiro \\
ligeiro \\
albergeiro \\
cheiro \\
coelheiro \\
conselheiro \\
ovelheiro \\
milheiro \\
compantremeiro \\
dinheiro \\
marinheiro \\
boieiro \\
granjeiro \\
jornaleiro \\
hospitaleiro \\
cuteleiro \\
esmoleiro \\
poleiro \\
\hline
\end{tabular}

armeiro
enfermeiro
postumeiro
cabaneiro
janeiro
asneiro
vidoeiro
pregoeiro
quinhoeiro
padroeiro
proeiro
nevoeiro
raçoeiro
copeiro
roupeiro
sombreiro
obreiro
pedreiro
pereiro
alfeireiro
esteireiro
palreiro
foreiro
guerreiro
matreiro
ostreiro
pegureiro
tesoureiro
usureiro
caseiro
despenseiro
fuseiro
solteiro
dianteiro
testamenteiro
prazenteiro
quinteiro
monteiro
fronteiro
marteiro
quarteiro
certeiro
porteiro
mosteiro
outeiro
fagueiro

bragueiro

reguengueiro

albergueiro

vergueiro

alugueiro

fanqueiro

arqueiro

grueiro

faveiro

peixeiro

agueiro

cabaceira

caldeira

joelheira

olheira

azinheira

macieira

laranjeira

corujeira

escaleira

moleira

lameira

palmeira

janeira

avelaneira

maneira

peneira

mineira

brafoneira

pulmoeira

pedreira

freira

baforeira

seira

traseira

masseira

regateira

goteira

porteira

esteira

giesteira

costeira

fogueira

porqueira

caveira 
SÉCULO XIV

aceiro
paceiro
feiticeiro
tenceiro
garceiro
soldadeiro
andadeiro
vinhadeiro
estalajadeiro
ladeiro
bailadeiro
manadeiro
espadeiro
derradeiro
aguadeiro
mentideiro
fundeiro
candeeiro
meeiro
lumeeiro
portageiro
estrangeiro
soalheiro
quadrilheiro
caminheiro
louvaminheiro
cozinheiro
especieiro
vieiro
estaleiro
almoceleiro
azemeleiro
estreleiro
seleiro
casteleiro
moleiro
epistoleiro

remeiro

tambeira

cimeiro

padeira

coimeiro

cantadeira

dizimeiro

tecedeira

costumeiro

vendedeira

caneiro

vintaneiro

medideira

videira

onzeneiro

espaldeira

bandeira

cordeira

prisioneiro

timoneiro

segunda-feira

tanoeiro

quarta-feira

trapeiro

tripeiro

trompeiro

alfambareiro

terça-feira

sardinheira

cozinheira

aveleira

cimeira

romeira

costaneira

pederneira

amendoeira

joeira

ervoeira

seteira

peiteira

moiteira

dianteira

sementeira

parteira

lombrigueira

esterqueira

atueira

canaveira

oliveira

ameixeira

lazeira 


\begin{tabular}{|c|c|c|}
\hline \\
\hline \multicolumn{3}{|l|}{$\begin{array}{l}\text { SECULO XV } \\
\text { ribeiro }\end{array}$} \\
\hline estribeiro & cabaneiro & comendadeira \\
\hline trombeiro & medianeiro & ladeira \\
\hline faceiro & altaneiro & obradeira \\
\hline calaceiro & tafoneiro & cevadeira \\
\hline praceiro & cancioneiro & dedeira \\
\hline tapeceiro & taverneiro & landeira \\
\hline sobranceiro & torneiro & lumeeira \\
\hline ronceiro & comuneiro & sarapilheira \\
\hline jugadeiro & cordoeiro & cervilheira \\
\hline adivinhadeiro & oraçoeiro & agulheira \\
\hline soadeiro & alcancareiro & fieira \\
\hline cevadeiro & seareiro & amieira \\
\hline redeiro & lebreiro & vieira \\
\hline caldeiro & sovereiro & cabeleira \\
\hline viandeiro & caldeireiro & caneleira \\
\hline sendeiro & refeitoreiro & roleira \\
\hline bombardeiro & tintureiro & rameira \\
\hline espingardeiro & costureiro & tasneira \\
\hline merceeiro & balseiro & arpoeira \\
\hline obreeiro & bolseiro & aroeira \\
\hline cacheiro & useiro & daroeira \\
\hline flecheiro & mulateiro & ameixoeira \\
\hline archeiro & azeiteiro & papeira \\
\hline mealheiro & volteiro & copeira \\
\hline malheiro & canteiro & camareira \\
\hline serralheiro & marnoteiro & tenreira \\
\hline cuvilheiro & porteiro & amoreira \\
\hline cosculheiro & costeiro & caseira \\
\hline tardinheiro & couteiro & roseira \\
\hline galinheiro & cueiro & chousseira \\
\hline lisonjeiro & afagueiro & chouseira \\
\hline espojeiro & triagueiro & fruiteira \\
\hline remeleiro & fragueiro & alcoviteira \\
\hline papeleiro & adegueiro & junteira \\
\hline foleiro & barregueiro & murteira \\
\hline sucroalcooleiro & pessegueiro & esteira \\
\hline atoleiro & mexeriqueiro & cegueira \\
\hline postrimeiro & vasqueiro & peitogueira \\
\hline lastimeiro & craveiro & manqueira \\
\hline postimeiro & fouveiro & panasqueira \\
\hline sesmeiro & vezeiro & baveira \\
\hline
\end{tabular}


SÉCULO XVI

lombeiro

chumbeiro

aljubeiro

bagaceiro

maceiro

couraceiro

aguaceiro

adiceiro

meiguiceiro

sinceiro

roceiro

barceiro

picadeiro

afagadeiro

despenhadeiro

vindimadeiro

paradeiro

palradeiro

benzedeiro

fiandeiro

crendeiro

vendeiro

alabardeiro

albardeiro

colmeeiro

rafeiro

alfeiro

passageiro

cocheiro

borralheiro

abelheiro

artilheiro

olheiro

olheiro

agulheiro

engenheiro

bufarinheiro

vinheiro

medronheiro

coronheiro

abrunheiro

caieiro

cirieiro

azevieiro

gajeiro

atabaleiro

cameleiro

marmeleiro

janeleiro

prateleiro

pasteleiro

noveleiro arrabileiro

tamborileiro

jamboleiro

gondoleiro

anzoleiro

tabuleiro

ulmeiro

marceneiro

mineiro

menineiro

chapineiro

atafoneiro

racioneiro

gonfaloneiro

forneiro

colchoeiro

alfeloeiro

tamoeiro

latoeiro

botoeiro

tençoeiro

napeiro

lampeiro

vespeiro

lambareiro

careiro

açucareiro

fogareiro

mareiro

pomareiro

altareiro

odreiro

peneireiro

joeireiro

tenreiro

chocarreiro

cafarreiro

alcaparreiro

terreiro

zorreiro

canastreiro

ventureiro

aventureiro

montureiro

livreiro

ananaseiro

braseiro

traseiro

interesseiro

grosseiro

gateiro

mateiro nateiro

barateiro

sorrateiro

calceteiro

escopeteiro

barreteiro

mosqueteiro

confeiteiro

oiteiro

alcoviteiro

lenteiro

casamenteiro

cinteiro

ponteiro

ponteiro

escoteiro

esparteiro

morteiro

rasteiro

forasteiro

giesteiro

cabresteiro

reposteiro

mamposteiro

biscouteiro

fueiro

formigueiro

tangueiro

adargueiro

sirgueiro

cajueiro

atabaqueiro

faqueiro

biqueiro

fraldiqueiro

chiqueiro

peliqueiro

corriqueiro

banqueiro

albricoqueiro

choqueiro

roqueiro

roqueiro

porqueiro

frasqueiro

cabouqueiro

cavouqueiro

craveiro

coveiro

caixeiro

queixeiro

araçazeiro 


banzeiro
arcabuzeiro
cajuzeiro
sagueiro
mangabeira
pitombeira
pacobeira
alfarrobeira
chumaceira
ribanceira
lanceira
barranceira
coceira
couceira
touceira
ajudadeira
embaladeira
escumadeira
abotoadeira
lavradeira
amassadeira
lançadeira
trançadeira
batedeira
frigideira
dormideira
cerzideira
fiandeira
lindeira

$\begin{array}{ll}\text { gilbardeira } & \text { ombreira } \\ \text { bombardeira } & \text { magreira } \\ \text { rageira } & \text { cenreira } \\ \text { cacheira } & \text { barreira } \\ \text { cacheira } & \text { parreira } \\ \text { montanheira } & \text { canseira } \\ \text { padieira } & \text { bateira } \\ \text { cuieira } & \text { vinhateira } \\ \text { cerejeira } & \text { jarreteira } \\ \text { ginjeira } & \text { monteira } \\ \text { gorjeira } & \text { ponteira } \\ \text { janeleira } & \text { escoteira } \\ \text { fileira } & \text { rambuteira } \\ \text { coleira } & \text { biscouteira } \\ \text { bandoleira } & \text { ragueira } \\ \text { limeira } & \text { melgueira } \\ \text { caganeira } & \text { mangueira } \\ \text { bananeira } & \text { ipueira } \\ \text { caçaneira } & \text { jaqueira } \\ \text { charneira } & \text { arequeira } \\ \text { cangoeira } & \text { fraldiqueira } \\ \text { cachoeira } & \text { barranqueira } \\ \text { salmoeira } & \text { tranqueira } \\ \text { capoeira } & \text { roqueira } \\ \text { ladroeira } & \text { pesqueira } \\ \text { açafroeira } & \text { faveira } \\ \text { toupeira } & \text { craveira } \\ \text { reira } & \text { cuscuzeira } \\ \text { cantareira } & \end{array}$


SÉCULO XVII

gambeiro

lambeiro

pombeiro

trapaceiro

doceiro

tremoceiro

alperceiro

louceiro

atascadeiro

tragadeiro

resvaladeiro

atoladeiro

lampadeiro

amassadeiro

roedeiro

vivandeiro

merendeiro

forrageiro

facheiro

tocheiro

alpercheiro

telheiro

roupa-velheiro

pilheiro

acenheiro

tamarinheiro

passarinheiro

cieiro

cerieiro

arrieiro

aguieiro

picheleiro

charameleiro

chineleiro

reboleiro

bandoleiro

paroleiro

rameiro

anteprimeiro

palmeiro

paneiro

aduaneiro

palafreneiro

carabineiro

jardineiro

tamarineiro

pensioneiro

arneiro

relojoeiro

limoeiro

jenipapeiro

colhereiro

jagreiro

milagreiro
vinagreiro
pandeireiro
janeireiro
sombreireiro
carreiro
madureiro
retroseiro
aljubeteiro
piveteiro
gazeteiro
empreiteiro
pirliteiro
gariteiro
pilriteiro
aguardenteiro
pimenteiro
parenteiro
tinteiro
roteiro
carteiro
lagarteiro
apisteiro
arquimosteiro
embusteiro
adueiro
adueiro
alfandegueiro
lamegueiro
trigueiro
bangueiro
moringueiro
mondongueiro
dainequeiro
sequeiro
botiqueiro
coqueiro
albaricoqueiro
charqueiro
lambisqueiro
marisqueiro
viveiro
luveiro
cajazeiro
urucuzeiro
beira
goiabeira
algibeira
ceira
aguaceira
terceira
lardeadeira
regadeira

trepadeira

joeiradeira

roedeira

varredeira

cingideira

grandeira

merendeira

mostardeira

borracheira

cocheira

cordilheira

pilheira

lentilheira

focinheira

frieira

mosca-varejeira

queijeira

caleira

gameleira

gomeleira

veleira

carcapuleira

romeira

sobremaneira

ventaneira

leoneira

escorcioneira

troneira

torneira

ratoeira

nevoeira

almiscareira

lareira

tamareira

umbreira

colhereira

aboboreira

moreira

carreira

torreira

viseira

salseira

sapateira

canteira

maroteira

fruteira

tramagueira

pitangueira

frasqueira

sueira

chaveira

pacoveira

macaxeira 


\begin{tabular}{|c|c|c|}
\hline \multicolumn{3}{|l|}{ SÉCULO XVIII } \\
\hline jambeiro & abieiro & catapereiro \\
\hline bilimbeiro & penitencieiro & titereiro \\
\hline aceiro & adagieiro & azereiro \\
\hline rabaceiro & machieiro & cabeleireiro \\
\hline sedaceiro & comboieiro & liteireiro \\
\hline vidraceiro & zambujeiro & alcanforeiro \\
\hline caleceiro & curraleiro & perreiro \\
\hline preguiceiro & saleiro & peidorreiro \\
\hline estanceiro & cavaleiro & abutreiro \\
\hline poceiro & pinceleiro & toureiro \\
\hline puceiro & toneleiro & sepultureiro \\
\hline moscadeiro & chapeleiro & raposeiro \\
\hline mondadeiro & bagateleiro & passeiro \\
\hline tenente-brigadeiro & broqueleiro & vinhateiro \\
\hline major-brigadeiro & veleiro & carrapateiro \\
\hline malhadeiro & faveleiro & patarateiro \\
\hline malhadeiro & noveleiro & prateiro \\
\hline mijadeiro & brasileiro & ramalheteiro \\
\hline desfiladeiro & fuzileiro & alfineteiro \\
\hline fanadeiro & reboleiro & fogueteiro \\
\hline granadeiro & caramboleiro & leiteiro \\
\hline limonadeiro & violeiro & paliteiro \\
\hline desaguadeiro & tituleiro & mosquiteiro \\
\hline hospedeiro & apostemeiro & salteiro \\
\hline sedeiro & olmeiro & manteiro \\
\hline sumideiro & maneiro & vestimenteiro \\
\hline prebendeiro & passamaneiro & maracoteiro \\
\hline segundeiro & paneiro & bisbilhoteiro \\
\hline cardeiro & costaneiro & caloteiro \\
\hline tardeiro & salineiro & marroteiro \\
\hline mostardeiro & mineiro & parteiro \\
\hline poleeiro & jasmineiro & festeiro \\
\hline ceifeiro & campineiro & alpisteiro \\
\hline galhofeiro & invencioneiro & flauteiro \\
\hline viageiro & parcioneiro & fruteiro \\
\hline segeiro & provisioneiro & cacaueiro \\
\hline macheiro & ratoneiro & cagueiro \\
\hline chocalheiro & pontoneiro & bodegueiro \\
\hline migalheiro & carneiro & pegueiro \\
\hline cangalheiro & carneiro & mogangueiro \\
\hline joalheiro & borneiro & pirangueiro \\
\hline paralheiro & saboeiro & mandingueiro \\
\hline marralheiro & gamboeiro & rezingueiro \\
\hline milheiro & algodoeiro & candongueiro \\
\hline armilheiro & mamoeiro & trasfogueiro \\
\hline tornilheiro & pisoeiro & sabugueiro \\
\hline fulheiro & alavoeiro & tabaqueiro \\
\hline lenheiro & tiçoeiro & molanqueiro \\
\hline sardinheiro & papeiro & alparqueiro \\
\hline linheiro & papeiro & casqueiro \\
\hline mezinheiro & sopeiro & damasqueiro \\
\hline unheiro & linguareiro & chavasqueiro \\
\hline
\end{tabular}




pesqueiro
faisqueiro
saveiro
alveiro
oveiro
ingazeiro
chazeiro
maracujazeiro
oitizeiro
buritizeiro
cinzeiro
araticunzeiro
cuscuzeiro
cruzeiro
jabuticabeira
bicuibeira
pombeira
chumbeira
andirobeira
sobeira
carnaubeira
ceira
bagaceira
maceira
mormaceira
taceira
pedranceira
arquicadeira
trincadeira
andadeira
bordadeira
carregadeira
respigadeira
salgadeira
pingadeira
rachadeira
solinhadeira
criadeira
assoviadeira
gramadeira

\begin{tabular}{|c|c|}
\hline $\begin{array}{l}\text { tendedeira } \\
\text { premedeira }\end{array}$ & estrumeira \\
\hline moedeira & $\begin{array}{l}\text { zabaneira } \\
\text { maganeira }\end{array}$ \\
\hline poedeira & munhoneira \\
\hline rompedeira & sobremunhoneira \\
\hline zunideira & timoneira \\
\hline carpideira & perneira \\
\hline parideira & asneira \\
\hline abrideira & saboeira \\
\hline bolandeira & zamboeira \\
\hline vivandeira & tanchoeira \\
\hline rodeira & mamoeira \\
\hline albufeira & cantoeira \\
\hline bicheira & carvoeira \\
\hline tocheira & trapeira \\
\hline cartucheira & sopeira \\
\hline gargalheira & ambareira \\
\hline coelheira & tareira \\
\hline orelheira & obreira \\
\hline milheira & abobreira \\
\hline serapilheira & bebereira \\
\hline rilheira & vinagreira \\
\hline fulheira & alcanforeira \\
\hline tanganheira & nitreira \\
\hline molinheira & loureira \\
\hline caieira & tintureira \\
\hline pieira & pulseira \\
\hline pavieira & amargoseira \\
\hline varejeira & chocolateira \\
\hline toranjeira & cafeteira \\
\hline esponjeira & topeteira \\
\hline tincaleira & confeiteira \\
\hline taleira & liteira \\
\hline frontaleira & piteira \\
\hline cristaleira & tonteira \\
\hline singeleira & carteira \\
\hline prateleira & torteira \\
\hline faveleira & besteira \\
\hline reboleira & gagueira \\
\hline sarcocoleira & sangueira \\
\hline frioleira & tamargueira \\
\hline peroleira & ronqueira \\
\hline sobre-soleira & faisqueira \\
\hline canhameira & sorveira \\
\hline ulmeira & cajazeira \\
\hline sumaumeira & soeiras \\
\hline
\end{tabular}




\begin{tabular}{|c|c|c|}
\hline graeiro & queijadeiro & salsicheiro \\
\hline beiro & arranjadeiro & pechincheiro \\
\hline quiabeiro & queimadeiro & bucheiro \\
\hline sebeiro & mesnadeiro & medalheiro \\
\hline ribeiro & namoradeiro & galheiro \\
\hline tambeiro & estradeiro & fornalheiro \\
\hline muambeiro & cantadeiro & agasalheiro \\
\hline tarimbeiro & lavadeiro & retalheiro \\
\hline bombeiro & rezadeiro & carvalheiro \\
\hline pombeiro & almoedeiro & relheiro \\
\hline tombeiro & torpedeiro & seguidilheiro \\
\hline pitombeiro & contratorpedeiro & holandilheiro \\
\hline tumbeiro & segredeiro & pandilheiro \\
\hline lobeiro & renhideiro & manilheiro \\
\hline lobeiro & videiro & bandarilheiro \\
\hline balobeiro & rescaldeiro & ladrilheiro \\
\hline barbeiro & valdeiro & guerrilheiro \\
\hline bicho-barbeiro & locandeiro & presilheiro \\
\hline adubeiro & pandeiro & pontilheiro \\
\hline negaceiro & curandeiro & quinquilheiro \\
\hline cangaceiro & quitandeiro & coscuvilheiro \\
\hline sargaceiro & guandeiro & folheiro \\
\hline cachaceiro & lindeiro & barulheiro \\
\hline chalaceiro & tamarindeiro & marulheiro \\
\hline melaceiro & embondeiro & banheiro \\
\hline lamaceiro & fundeiro & tanganheiro \\
\hline plumaceiro & pagodeiro & patranheiro \\
\hline brumaceiro & todeiro & alfenheiro \\
\hline borraceiro & bastardeiro & bainheiro \\
\hline ruaceiro & ordeiro & molinheiro \\
\hline arruaceiro & desordeiro & pergaminheiro \\
\hline peliceiro & chafurdeiro & farinheiro \\
\hline chamiceiro & cafeeiro & armarinheiro \\
\hline tamiceiro & boleeiro & sanguinheiro \\
\hline chouriceiro & femeeiro & gandaieiro \\
\hline lambanceiro & penteeiro & balaieiro \\
\hline chanceiro & abafeiro & praieiro \\
\hline balanceiro & taifeiro & catraieiro \\
\hline romanceiro & algerifeiro & estancieiro \\
\hline financeiro & farofeiro & vigieiro \\
\hline palhoceiro & trufeiro & vimieiro \\
\hline carroceiro & bagageiro & antevieiro \\
\hline murceiro & ferrageiro & mostajeiro \\
\hline chuceiro & limão-de-cheiro & igrejeiro \\
\hline arribadeiro & hortelã-de-cheiro & caranguejeiro \\
\hline recadeiro & cacheiro & cervejeiro \\
\hline novidadeiro & facheiro & queijeiro \\
\hline liberdadeiro & penacheiro & laranjeiro \\
\hline apeadeiro & capacheiro & tojeiro \\
\hline veadeiro & pistacheiro & alforjeiro \\
\hline jangadeiro & salchicheiro & timbaleiro \\
\hline boiadeiro & trapicheiro & pedaleiro \\
\hline
\end{tabular}




sinaleiro
jornaleiro
raleiro
coraleiro
foraleiro
inospitaleiro
valeiro
adeleiro
rodeleiro
cingeleiro
meleiro
paneleiro
tineleiro
peleiro
hoteleiro
quarteleiro
corteleiro
soveleiro
anileiro
funileiro
grileiro
anglo-brasileiro
luso-brasileiro
boleiro
caracoleiro
argoleiro
paioleiro
tijoleiro
roleiro
faroleiro
petroleiro
franduleiro
capituleiro
gameiro
balsameiro
moxameiro
pantomimeiro
gomeiro
são-joaneiro
peneiro
lagumeiro
plumeiro
trameiroineiro
galbaneiro
chicaneiro
bucaneiro
chanfaneiro
organeiro

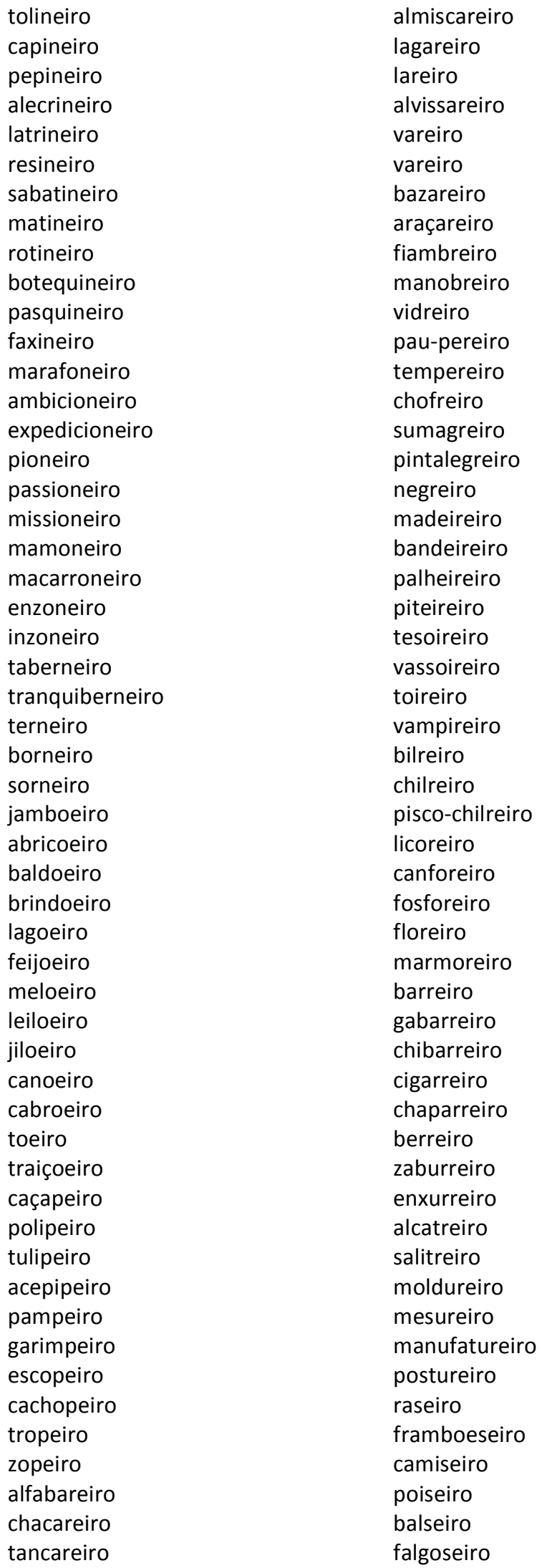




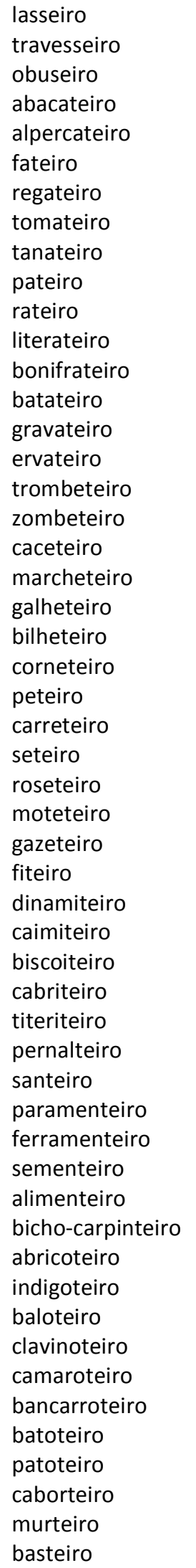

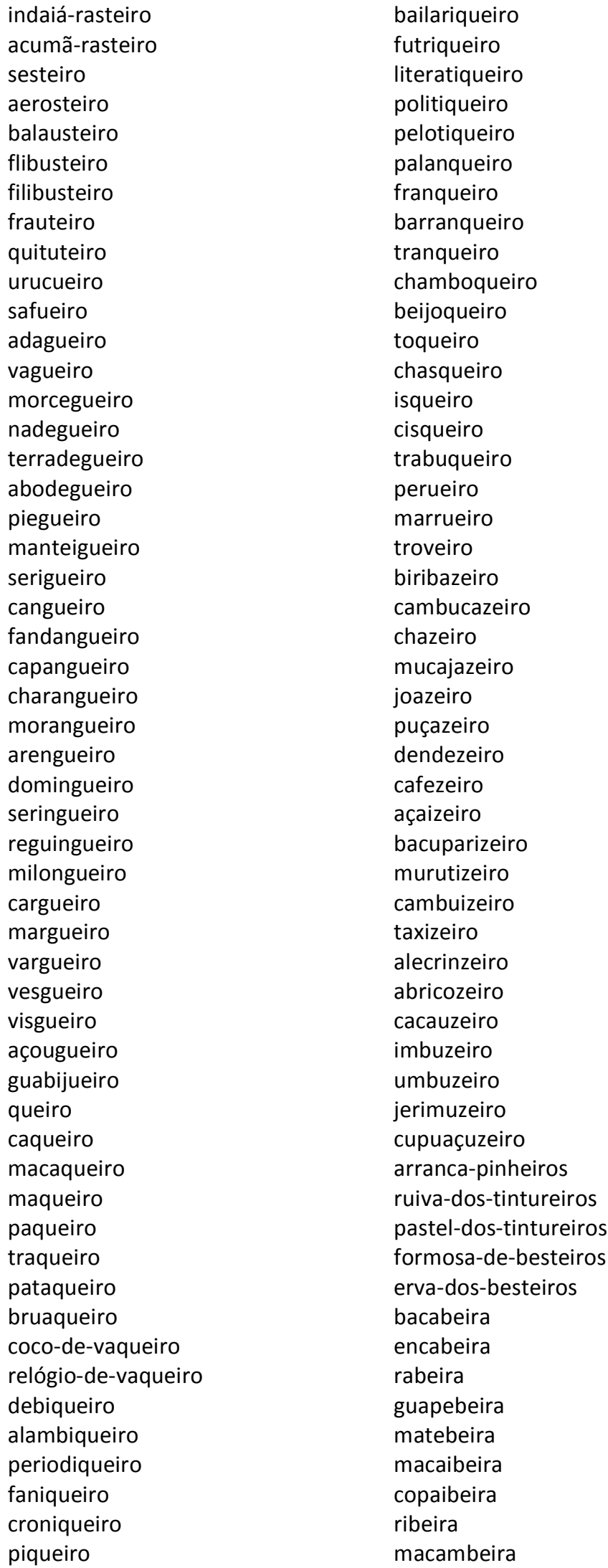




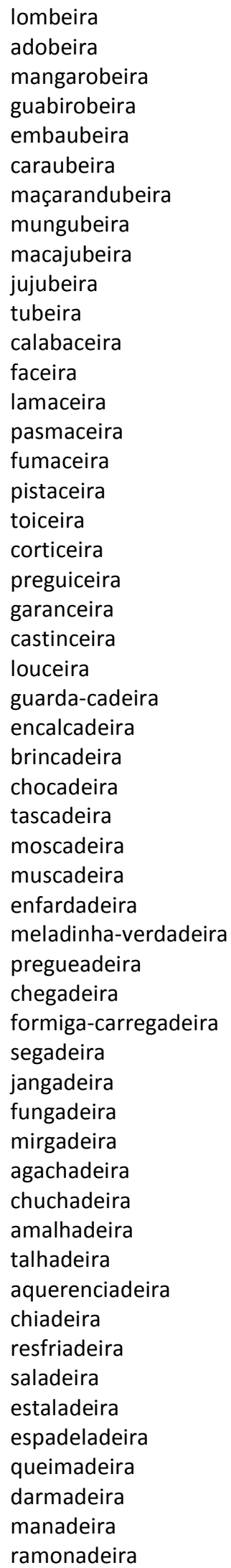

\begin{tabular}{|c|c|}
\hline $\begin{array}{l}\text { esfarrapadeira } \\
\text { ripadeira } \\
\text { apalpadeira }\end{array}$ & $\begin{array}{l}\text { bufeira } \\
\text { trufeira } \\
\text { bagageira }\end{array}$ \\
\hline raspadeira & ligeira \\
\hline chupadeira & rabugeira \\
\hline quebradeira & trincheira \\
\hline sangradeira & poncheira \\
\hline tiradeira & bucheira \\
\hline namoradeira & erva-alheira \\
\hline escarradeira & roubalheira \\
\hline erva-espirradeira & chocalheira \\
\hline javradeira & bandalheira \\
\hline assisadeira & farfalheira \\
\hline lissadeira & ramalheira \\
\hline natadeira & cremalheira \\
\hline espreitadeira & soalheira \\
\hline assentadeira & borralheira \\
\hline empacotadeira & estralheira \\
\hline encartadeira & abelheira \\
\hline arrastadeira & relheira \\
\hline cavadeira & groselheira \\
\hline lavadeira & botelheira \\
\hline escovadeira & serrapilheira \\
\hline rebaixadeira & erva-piolheira \\
\hline espreguiçadeira & molheira \\
\hline calçadeira & solheira \\
\hline espinçadeira & erva-agulheira \\
\hline roçadeira & torda-mergulheira \\
\hline bebedeira & barulheira \\
\hline erva-moedeira & banheira \\
\hline corredeira & panheira \\
\hline subideira & aranheira \\
\hline urdideira & talinheira \\
\hline repartideira & pinheira \\
\hline acará-bandeira & erva-pinheira \\
\hline pirá-bandeira & carapinheira \\
\hline volandeira & farinheira \\
\hline quitandeira & murtinheira \\
\hline rendeira & unheira \\
\hline undeira & pupunheira \\
\hline pagodeira & ubaieira \\
\hline rosa-albardeira & sapucaieira \\
\hline bastardeira & uaieira \\
\hline baleeira & uvaieira \\
\hline peeira & melancieira \\
\hline quinta-feira & berlandieira \\
\hline abafeira & sarapieira \\
\hline gafeira & pêra-da-aguieira \\
\hline garrafeira & toronjeira \\
\hline bifeira & leira \\
\hline almofeira & dedaleira \\
\hline rfeira & chaleira \\
\hline rfeira & materialeira \\
\hline
\end{tabular}




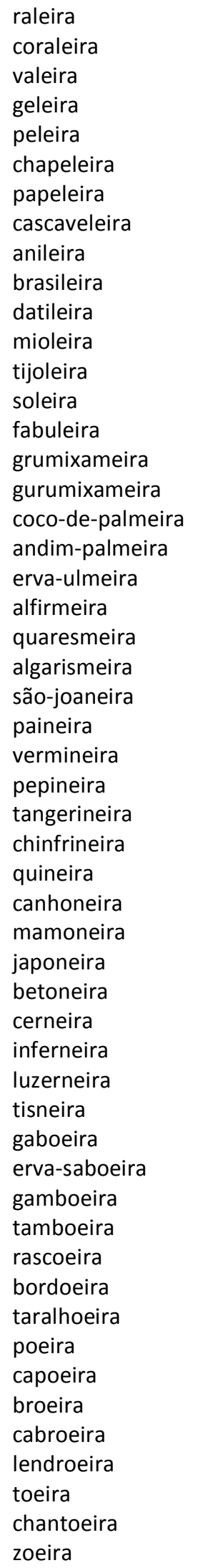

\begin{tabular}{|c|c|}
\hline cachapeira & leiteira \\
\hline garoupeira & erva-leiteira \\
\hline açucareira & maleiteira \\
\hline angareira & paliteira \\
\hline clareira & açoiteira \\
\hline rareira & pimenteira \\
\hline passareira & erva-pimenteira \\
\hline vareira & erva-conteira \\
\hline celebreira & lingoteira \\
\hline quebreira & capoteira \\
\hline sombreira & tetipoteira \\
\hline sobreira & compoteira \\
\hline pau-pereira & testeira \\
\hline coxa-de-freira & charuteira \\
\hline enxofreira & chagueira \\
\hline licoreira & almecegueira \\
\hline floreira & erva-pessegueira \\
\hline marmoreira & fedigueira \\
\hline esporeira & cardigueira \\
\hline cigarreira & manteigueira \\
\hline alcaparreira & folha-de-figueira \\
\hline catarreira & erva-formigueira \\
\hline enxurreira & madrigueira \\
\hline ostreira & barrigueira \\
\hline cabureira & salgueira \\
\hline mureira & cangueira \\
\hline erva-tintureira & mangueira \\
\hline montureira & seringueira \\
\hline aniseira & caatingueira \\
\hline lapiseira & mondongueira \\
\hline tanseira & calungueira \\
\hline boseira & margueira \\
\hline baboseira & purgueira \\
\hline passeira & manipueira \\
\hline travesseira & tabaqueira \\
\hline cosseira & maqueira \\
\hline fuseira & erva-traqueira \\
\hline eira & buraqueira \\
\hline quilateira & taqueira \\
\hline charlateira & pataqueira \\
\hline mulateira & estaqueira \\
\hline mateira & tuaqueira \\
\hline rateira & erva-vaqueira \\
\hline ateira & cavaqueira \\
\hline ombeteira & molequeira \\
\hline lanceteira & biqueira \\
\hline feteira & tamanqueira \\
\hline leteira & tronqueira \\
\hline alfineteira & boqueira \\
\hline saboneteira & barroqueira \\
\hline rreteira & soqueira \\
\hline rveteira & barqueira \\
\hline gaiteira & marisqueira \\
\hline
\end{tabular}


petisqueira

lentisqueira

trovisqueira

rouqueira

crueira

batueira

calaveira

talaveira
buxeira
puxeira
ingazeira
tramazeira
cuitezeira
raizeira

vernizeira

guizeira

bozeira

avelãzeira

romãzeira

agueira

bela-de-felgueiras 


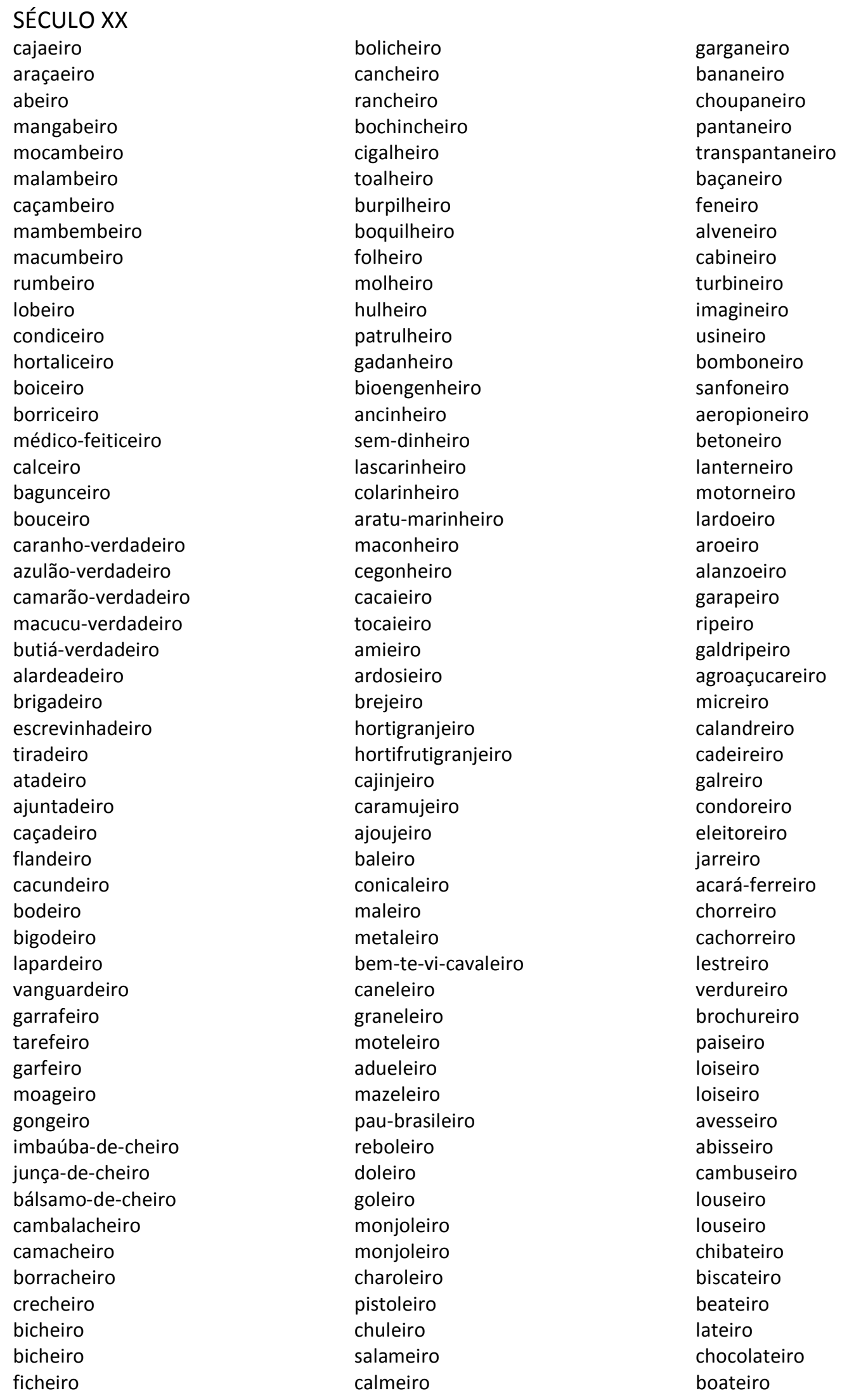




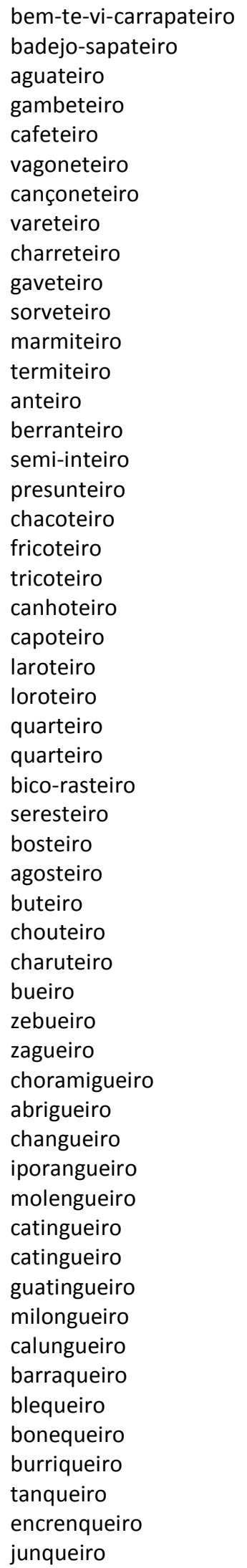

\begin{tabular}{|c|}
\hline 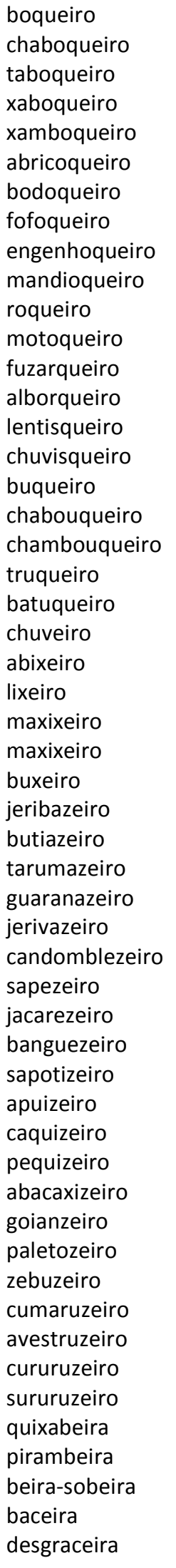 \\
\hline
\end{tabular}

buliceira

bananeirinha-de-touceira

adeira

adubadeira

cadeira

calcadeira

rocadeira

nadadeira

enredadeira

chuleadeira

acaseadeira

penteadeira

ceifadeira

desmanchadeira

marchadeira

baladeira

açacaladeira

geladeira

bailadeira

coladeira

tambuladeira

madeira

dardamadeira

mamadeira

arrumadeira

capinadeira

palecionadeira

aparadeira

enceradeira

cheiradeira

atiradeira

desnatadeira

britadeira

picotadeira

abortadeira

escavadeira

alinhavadeira

pasteurizadeira

caba-caçadeira

braçadeira

abraçadeira

almoçadeira

tremedeira

ganideira

porta-bandeira

bagre-bandeira

tucandeira

incendeira

bigodeira

derreeira

capacheira

flecheira

rancheira 


malheira
cornalheira
gadelheira
parelheira
hulheira
entulheira
gadanheira
cicieira
gafieira
carrieira
canavieira
má-jeira
brejeira
aranha-caranguejeira
sujeira
chaleira
chaleira
sinaleira
cameleira
anta-gameleira
aneleira
coqueteleira
tornozeleira
calumba-brasileira
boleira
reboleira
andorinha-coleira
pistoleira
adarmeira
ghopeirameira
mafumeira
agreira
ganeira
banzoiraira
traineira
jardineira
capineira
bomboneira
anoneira
soneira
cantoneira
caçoneira
caraxué-da-capoeira
garroeira

canforeira

branco-parreira

chorreira

seira

camiseira

loiseira

groseira

louseira

cacateira

lateira

mateira

carrapateira

anta-sapateira

feiteira

feiteira

biscoiteira

besteira

chuteira

bueira

bagueira

chumbregueira

xumbregueira

besouro-da-figueira

cervigueira

mangueira

rengueira

munhequeira

galiqueira

junqueira

biboqueira

nhoqueira

casqueira

churrasqueira

chavasqueira

águia-pesqueira

chambruqueira

esteveira

silveira

lixeira

borrazeira

zonzeira

cruzeira

boleadeiras

milheiras

barata-das-palmeiras 


\section{OBRAS CONSULTADAS:}

ADAMS, Valerie. An introduction to modern English word-formation. London: Longman, 1973.

AIJMER, Karin. The semantic development of will. In: FISIAK, Jacek. Historical Semantics, Historical wordformation. Berlin/ New York/ Amsterdam: Mouton, 1985, pp. 11-21.

ALVES, leda M. Neologismo: criação lexical. São Paulo: Ática, 1994.

ANDERSEN, Henning. A study in diachronic morphophonemics: the Ukranian prefixes. Language 1969(45):807-830.

. Abductive and deductive change. Language. 1973(49): 765-793.

. Towards a typology of change: bifurcating changes and binary relations. In: ANDERSON, John M. \& JONES, Charles. Historical linguistics, 1975 (2): 18-62.

. Morphological change: towards a typology. In: FISIAK, Jacek. Historical Morphology. The Hague/ Paris/ New York: Mouton, 1980, pp. 1-50.

ANDERSON, Stephen R. On the development of morphology from syntax. In: FISIAK, Jacek. Historical Morphology. The Hague/ Paris/ New York: Mouton, 1980, pp. 51-69.

. A-morphous Morphology. Cambridge: CUP, 1992.

. On some issues in morphological exponence. Yearbook of Morphology 2000. 2001: 1-18.

.; JONES, Charles (ed.). Proceedings of the First International Conference on Historical Linguistics. Amsterdam: North-Holland, 1975.

ANTTILA, Raimo. Analogy. Helsinki: University od Helsinki, 1974; The Hague: Mouton, $1977^{2}$. . An introduction to historical and comparative linguistics. New York: MacMillan, 1975.

. The indexical element im morphology. Innsbrucker Beiträge zur Sprachwissenschaft, Vorträge 12. Innsbruck: Institut für Sprachwissenschaft der Universität, 1975a. . The metamorphosis of allomorphs. Lacus 2: 238-249, $1975 \mathrm{~b}$.

AREÁN-GARCÍA, Nilsa. Estudo comparativo de aspectos semânticos do sufixo -ista no português e no galego. Dissertação de mestrado. São Paulo: FFLCH-USP, 2007.

ARONOFF, Mark. Word formation in generative Grammar. Cambridge, Mass/ London: MIT, 1976. . The relevance of productivity in a synchronic description of word formation. In: FISIAK, Jacek. Historical Morphology. The Hague/ Paris/ New York: Mouton, 1980, pp. 71-82. . Potential words, actual words, productivity and frequency. In: HATTORI, Shirô; INOUE, Kazuko. Proceedings of the XIII International Congress of Linguists. Tokyo: CIPL, 1983, pp. 163-171. (ed). Morphology now. Albany: State University of New York, 1992.

. Morphology by itself: stems and inflectional classes. Cambridge, MA: MIT, 1994.

. Isomorphism and monotonicity: or the disease model of Morphology. In: LAPOINTE, Steven G.; BRENTARI, Diane K.; FARRELL, Patrick M. Morphology and its relation to Phonology and Syntax. Stanford: CSLI, 1998, pp. 411-418.

; SCHVANEFELDT, Roger. Testing morphological productivity. Annals of the New York Academy of Sciences. 1978 (318): 106-114.

ASHEN, Frank; ARONOFF, Mark. Morphological productivity and phonological transparency. Canadian Journal of Linguistics. 1981 (26). 1.63-72.

$\mathrm{BACH}$, Emmond; HARMS, Richard (ed) Universals in linguistic theory. New York: Holt, Rinehart \& Winston, 1968.

BAKHTIN, Mikhail. Marxismo e filosofia da linguagem. São Paulo: Hucitec, 1988.

BALLY, Charles. Linguistique générale et linguistique française. Berne : Francke, 1944.

BAERMAN, Matthew; CORBETT, Greville; BROWN, Dunstan; HIPPISLEY, Andrew (ed). Deponency and Morphological Mismatches. Oxford: OUP, 2007.

BARBOSA, Jeronymo S. Grammatica philosophica da lingua portugueza. Lisboa, Academia Real de Sciencias, 1875.

BARON, Naomi. Language acquisition and historical change. Amsterdam: North Holland, 1977. 
BARRETO, João Franco. Ortografia da lingua portuguesa. Lisboa, Officina de loam da Costa, 1671.

BARROS, João de. Gramática da língua portuguesa. Reprod. facsim., leit., introd. e anot. por Maria L. Carvalhão Buescu. Lisboa, Publ. da Faculdade de Letras da Universidade de Lisboa, 1971.

BASILIO, Margarida: "O estudo da morfologia no português falado: condições de produtividade e condições de produção", em Castilho, Ataliba T. de (ed.), Gramática do português falado, vol. III. Campinas: Unicamp, 2002, p. 364-372.

. Formação e classes de palavras no português do Brasil. São Paulo: Contexto, 2004.

BATES, Elisabeth. Language and context: the acquisition of Pragmatics. New York: Academic Press, 1976.

BAUER, Laurie. English word-formation. Cambridge: CUP, 1988.

; VALERA, Salvador \& DÍAZ-NEGRILLO, Ana. Affixation vs. conversion: the resolution of conflicting patterns. In: RAINER, Franz; DRESSLER, Wolfgang; KASTOVSKY, Dieter \& LUSCHÜTZKY, Hans Christian. Variation and change in Morphology. Amsterdam/Philadelphia: John Benjamins, 2008, pp. 15-32.

BAZELL, Charles. On the problem of the morpheme. Archivum Lingusiticum, 1949 (1): 1-15.

BEARD, Robert. Lexeme-morpheme base Morphology: a general theory of inflection and word formation. Albany: State University of New York Press, 1995.

\& VOLPE, Mark. Lexeme-morpheme base Morphology. In: ŠTEKAUER, Pavol; LIEBER, Rochelle. Handbook for word-formation. Dordrecht: Springer, 2005, pp. 189-206.

BELLMANN, Günther. Zur Variation im Lexikon: Kurzwort und Original. Wirkendes Wort. 1980 (30): 369-383.

BEST, Karl-Heinz. Probleme der Analogieforschung. München: Hueber, 1973.[Review: FAUST, Manfred. Zeitschrift für Dialektologie und Linguistik 1977(14):183-187; Review: MEYERTHALER, Willi. Papiere zur Linguistik. München: Fink, 1974:124-130].

BIDERMAN, Maria T. C. Dicionário do estudante. São Paulo: Globo, 2005.

BLACK, Jeremy "History of morphological research: from antiquity to the $19^{\text {th }}$ century", em Booij, Geert / Christian Lehmann / Joachin Mugdan (eds.), Morphologie: ein internationales Handbuch zur Flexion und Wortbildung. Berlin / New York: Walter de Gruyter, 2000, p. 34-41.

BLACK, Max. Metaphor. Proceedings from the Aristotelian Society. 1954 (55): 273-294. [republicado em BLACK, Max. Models and metaphors. Ithaca: Cornell,1962].

BLOOMFIELD, Leonard. "A set of postulates for the science of language", Language 2, 1926, p. 153-164. . Language. London: George Allen \& Unwin, 1933.

$\overline{B L U T E A U}$, D. Rafael. Vocabulário portuguez e latino. Lisboa, Officina de Pascoal da Silva, 1720.

BOKAMBA, Eyamba B. The impact of multilingualism on language structures: the case of Central Africa. Studies in language learning. 1976 (1).2: 3-40.

BOND, Zinny S. Slips of the ear: errors in the perception of casual conversation. San Diego: Academic Press, 1999.

BOOIJ, Geert. Autonomous Morphology and paradigmatic relations. Yearbook of Morphology. pp. 35-53. . Construction Morphology and the Lexicon. In: BOYÉ, Gilles; HATHOUT, Nabil; MONTERMINI, Fabio. Selected Proceedings of the 5th décembrettes: Morphology in Toulose. Sommervilla, Mass: Cascadilla, 2007: 33-44.

BOPP, Franz. Über das Conjugationssystem der Sanskritsprache in Vergleichung mit jenem der griechischen, lateinischen, persischen und germanischen Sprachen. Frankfurt am Main: Andräische Buchhandlung, 1816.

BOURCIEZ, E. Éléments de linguistique romanique. Paris : Klincksieck, $1946^{4}$.

BREAL, Michel. Essai de sémantique (science des significations). Paris : Hachette, 1897.

BRÜCH, Josef. Zu Meyer-Lübkes etymologischem Wörterbuch. Zeitschrift für romanische Philologie. 1919 (39): 200-211.

BRUGMANN, Karl. Vergleichende Laut-, Stammbildungs- und Flexionlehre nebst Lehre vom Gebrauch der Wortformen. v2: Lehre von den Wortformen und ihrem Gebrauch. parte 1: Allgemeines, Zusammensetzung (Komposita), Nominalstämme. Strassburg: Trübner, 1906.

BURZIO, Luigi. Surface-to-surface Morphology: when your representations turn ito constraints. In: BOUCHER, Paul. Many Morphologies. Sommerville, Mass.: Cascadilla, 2002: 142-177.

BYBEE, Joan L. Morphology: a study of the relation between meaning and form. Amsterdam: Benjamins, $1985 a$. 
; HOPPER, Paul. Frequency and the emergence of the linguistic structure. Amsterdam / Philadelphia: John Benjamins, 2001.

; MODER, C. L. Morphological classes as natural categories. Language. 1983 (59): 251-270.

; PAGLIUCA, William. Cross-linguistic comparison and the development of grammatical meaning. In: FISIAK, Jacek. Historical Semantics, Historical word-formation. Berlin/ New York/ Amsterdam: Mouton, 1985b, pp. 59-83.

BYNON, Theodora. Historical linguistics. Cambridge: CUP, 1983.

CÂMARA Jr, Joaquim M. Estrutura da língua portuguesa. Petrópolis: Vozes, $2005^{37}\left[1970^{1}\right]$.

CAMPBELL, A. Old English grammar. Oxford: University Press, 1959.

CANNON, Garland. Blends in English word formation. Linguistics. 1986 (24): 725-753.

. Abbreviations and acronyms in English word-formation. American speech. 1989 (64): 2.99-127.

CARR, Charles T. Nominal compounds in Germanic. London: Humphrey Milford, 1939.

CEJADOR y FAUCA, Julio. Vocabulario medieval castellano. Madrid: Hernando, 1929.

CHAO, Yuen Ren. Language and symbolic systems. London: CUP, 1968.

CHOMSKY, Noam. Syntactic structures. The Hague: Mouton \& Co, 1957.

. A transformational approach to sintax. In: FODOR, Jerry A. \& KATZ, Jerrold J. The structure of language: readings in the philosophy of language. Englewood Cliffs, N.J.: Prentice-Hall, 1964, pp. 211245.

. Current issues in linguistic theory. In: FODOR, Jerry A. \& KATZ, Jerrold J. The structure of language: readings in the philosophy of language. Englewood Cliffs, N.J.: Prentice-Hall, 1964, pp. 50-118. . Aspects of the theory of syntax. Cambridge, Mass.: MIT, 1965.

. Cartesian linguistics: a chapter in the history of Rationalism thought. New York: Harper and Row, 1966.

. "Remarks on nominalization". In: JACOBS, Roderick A.; ROSENBAUM, Peter S. (eds.), Readings in English transformational grammar. Waltham / Toronto / London: Ginn and Company, 1970, p. 184221.

. Logical structure of Linguistic theory. New York: Plenum, 1975a.

Reflections on language. New York: Pantheon, 1975b.

. Rules and representations. New York: Columbia University Press, 1980.

. Lectures on government and binding. Dordrecht: Foris Publications, 1981.

; HALLE, M. The sound pattern of English. New York: Haper \& Row, 1968.

CHRISTIE, William (ed). Current progress in historical linguistics. Amsterdam: North-Holland, 1976.

CIONARESCU, Alejandro. Diccionario etimológico rumano. La Laguna: Universidad, 1960.

COMRIE, Bernard. Language universals and linguistic typology. Oxford: Basil Blackwell, 1981.

CONDÉ, Valéria G. Produtividade do sufixo -eria na língua portuguesa do Brasil. In: LIMA-HERNANDES, M.C.; MARÇALO, M.J.; MICHELETTI, G.; ROSSI, V.L... (Org.). A Língua Portuguesa no Mundo - I Simpósio Mundial de Estudos de Língua Portuguesa (CD-ROM). São Paulo: FFLCH USP, v.2, 2008.

COROMINAS, Joan. Diccionario crítico etimológico de la lengua castellana._Madrid:Gredos, 1954-1957. . Diccionario de términos filológicos. Madrid, Gredos, 1974.

; PASCUAL, José Antonio. Diccionario etimológico castellano e hispánico. Madrid: Gredos, 1976ss. . Breve diccionario etimológico de la lengua castellana. Madrid, Gredos, 1994.

CORBIN, Danielle. Morphologie dérivationelle et structuration du lexique. 2v. Tübingen: Max Niemeyer, 1987 ; Villeneuve d'Ascq : Presses Universitaires de Lille, $1991^{2}$.

CORPUS INSCRIPTIONUM LATINARUM. Berlin: Consilio et Auctoritate Academiæ Litterarum Regiæ Borussicæ editum, 1863 ss.

COSERIU, Eugenio. Sincronía, diacronía e historia: el problema del cambio lingüístico. Montevideo: Universidad de la República, 1958. . Sistema, norma y habla. In: COSERIU, Eugenio. Teoría del lenguaje y lingüística general. Madrid: Gredos, 1962.

- Sincronía, diacronía y tipología. Actos del XI Congreso Internacional de Lingüística y Filología Románica. Madrid, 1968 (1): 269-283.

COULMAS, Florian. Language adaptation. Cambridge: CUP, 1989. 
CSER, András. The -alis/ -aris allomorphy revisited. In: RAINER, Franz; DRESSLER, Wolfgang; KASTOVSKY, Dieter \& LUSCHÜTZKY, Hans Christian. Variation and change in Morphology. Amsterdam/Philadelphia: John Benjamins, 2008, pp. 33-52.

CUNHA, Antonio G. da. Dicionário etimológico Nova Fronteira da língua portuguesa. Rio de Janeiro, Nova Fronteira, 1982.

Dicionário histórico das palavras portuguesas de origem tupi. São Paulo: Melhoramentos/Edusp, [1978 $\left.{ }^{1}\right] 1989$.

. Dicionário etimológico Nova Fronteira da língua portuguesa. Rio de Janeiro: Nova Fronteira, 1982.

CUTLER, Anne. Productivity in word formation. Papers from the $16^{\text {th }}$ Regional Meeting - Chicago Linguistic Society. Chicago: Chicago Linguistic Society, 1980.

. Degrees of transparency in word formation. Canadian Journal of Linguistics. 1981 (26).1: 72-77.

DAHL, Östen. The growth and maintenance of linguistic complexity. Amsterdam/ Philadelphia: Benjamins, 2004.

DAL, Georgette \& NAMER, Fiammetta. French property nouns based on toponyms or ethnic adjectives: a case of base variation. In: RAINER, Franz; DRESSLER, Wolfgang; KASTOVSKY, Dieter \& LUSCHÜTZKY, Hans Christian. Variation and change in Morphology. Amsterdam/Philadelphia: John Benjamins, 2008, pp. 53-74.

DELBRÜCK, Berthold. Vergleichende Syntax der indogermanischen Sprachen. Straßburg: Trübner, 1893.

DERWING, Bruce; BAKER, William J. The psychological basis for morphological rules. In: MacNAMARA, John. Perspectives in Neurolinguistics and Psycholinguistics. New York: Academic Press, 1977, pp. 85-100.

DRACHMAN, Gaberell. Child language and language change: a conjecture and some refutations. In: FISIAK, Jacek (ed). Recent developments in historical phonology. The Hague: Mouton, 1978, pp.123-144.

DRESSLER, Wolfgang. Tendenzen in kontaminatorischen Fehlleistungen (und ihre Beziehung zur Sprachgeschichte). Die Sprache. 1976 (22):1-10.

Elements of a polycentrist theory of word formation. Wiener Linguistische Gazette. 1977 (15):15-32. . Outlines of a model of morphonology. In: DRESSLER, Wolfgang et alii. Phonologica 1980. Innsbruck: Institut für Sprachwissenschaft,1981, pp. 113-122.

On word formation in Natural Morphology. Wiener Linguistische Gazette. 1982a (26): 3-14.

. Zur semiotischen Begründung einer natürlichen Wortbildungslehre. Klagenfurter Beiträge zur Sprachwissenschaft. 1982b (8): 72-87.

. Morphonology: the dynamics of derivation. Ann Arbor: Karoma, 1985a.

Suppletion in word formation. In: FISIAK, Jacek. Historical Semantics, Historical word-formation.

Berlin/ New York/ Amsterdam: Mouton, 1985; pp. 97-112.

. Extragrammatical vs. marginal Morphology. In: DOLESCHAL, Ursula; THORNTON, Anna M. Extragrammatical and marginal Morphology. München: Lincom Europa, 2000, pp. 1-10.

. Word formation in Natural Morphology. In: ŠTEKAUER, Pavol; LIEBER, Rochelle. Handbook of wordformation. Dordrecht: Springer, 2005, pp. 267-284.

; DZIUBALSKA-KOŁACZYK, Katarzyna; GAGARINA, Natalia; KILANI-SCHOCH, Marianne. Reduplication in child language. In: $\mathrm{HURCH}$, Bernhard. Studies in reduplication. Berlin: Mouton de Gruyter, 2005, pp. 455-474.

; KARPF, Annemarie. The theoretical relevance of Pre- and Protomorphology in language acquisition. Yearbook of Morphology 1994. 1995: 99-122.

; MERLINI-BARBARESI, Lavinia. Morphopragmatics: diminutives and intensifiers in Italian, German, and other languages. Berlin/ New York: Mouton de Gruyter, 1994.

EGGERT, Elmar. Morphological variation in the construction of French names for inhabitants. In: RAINER, Franz; DRESSLER, Wolfgang; KASTOVSKY, Dieter \& LUSCHÜTZKY, Hans Christian. Variation and change in Morphology. Amsterdam/Philadelphia: John Benjamins, 2008, pp. 75-88.

ELSEN, Hilke. Neologismen. Formen und Funktionen neuer Wörter in verschiedenen Varietäten des Deutschen. Tübingen: Günter Narr, 2004.

ENCKELL, Pierre; RÉZEAU, Pierre. Dictionnaire des onomatopées. Paris: Quadrige/PUF, $2005^{2}$.

ERNOUT, Alfred. Morphologie historique du latin. Paris : Klincksieck, 1945. ; MEILLET, Antoine. Dictionnaire étymologique de la langue latine. Paris: Klincksieck, 2001 [1932 ${ }^{1}$ ].

ERTEL, Suitbert. Psychophonetik. Göttingen: Hogrefe, 1969. 
FAISS, Klaus. Verdunkelte Compounds im Englischen. Tübingen: Günther Narr, 1978.

FERGUSON, C. A.; SLOBIN, D. I. (ed) Studies in child language development. New York: Holt, Rinehart and Winston, 1973.

FILLMORE, Charles J. The case for case. In: BACH, Emmond; HARMS, Richard (ed) Universals in linguistic theory. New York: Holt, Rinehart \& Winston, 1968, pp. 1-88.

. Scenes-and-frames semantics. In: ZAMPOLLI, A. Linguistic structures processing. Amsterdam: North Holland, 1977a, pp. 55-82.

. The case for case reopened. In: COLE, Peter; SADDOCK, Jerrold (ed). Syntax and semantics 8: grammatical relations. New York: Academic Press, 1977b, pp. 59-81.

. Towards a descriptive framework for spatial deixis. In: JARVELLA, R.; KLEIN, W. Speech, place and action. Chichester: John Wiley, 1982: 31-59.

FLEISCHER, Wolfgang; BARZ, Irmhild. Woortbildung der deutschen Gegenwartssparche. Tübingen: Niemeyer, $1995^{2}$.

FODOR, Jerry A. \& KATZ, Jerrold J. The structure of language: readings in the philosophy of language. Englewood Cliffs, N.J.: Prentice-Hall, 1964.

FORGÁCS, Erszébet; GÖNDÖCS, Ágnes. Sprachspiele in der Werbung. Studia germanica Universitatis Vesprimiensis. 1997 (1): 49-70.

FRADIN, Bernard. Combining forms, blends and related phenomena. In : DOLESCHAL, Ursula \& THORNTON, Anna M. Extragrammatical and marginal Morphology. München: Lincom Europa, 2000, pp. 11-59. . Nouvelles approches en morphologie. Paris: Presses Universitaires de France, 2003.

FRANCIS, Elaine J. \& MICHAELIS, Laura A. Mismatch: a crucible for linguistic theory. In FRANCIS, Elaine J. \& MICHAELIS, Laura A. Mismatch: form-function incongruity and the architecture of grammar. Stanford: CSLI, 2003, pp. 1-27.

FRASER, Thomas. Etymology and the lexical semantics of the Old English preverb be- In: FISIAK, Jacek. Historical Semantics, Historical word-formation. Berlin/ New York/ Amsterdam: Mouton, 1985, pp. 113-126.

FREITAS, Érica S. S. Em busca do mento perdido: análise semântico-diacrônica do sufixo -mento, no português. Dissertação de mestrado. São Paulo: FFLCH-USP, 2008.

GABELENTZ, Georg von der. Die Sprachwissenschaft. Ihre Aufgaben. Methoden un bisherige Ergebnisse. Leipzig: Tauchnitz, $1901^{2}$.

GADDE, Frederick. On the history and use of the suffixes -ery, (-ry), -age and -ment in English. Lund: Gleerupska Univ. Bokhandeln, 1910.

GAETA, Livio. The invisible hand of grammaticalization : West-Germanic substitutive infinitive and the prefix ge-. In: RAINER, Franz; DRESSLER, Wolfgang; KASTOVSKY, Dieter \& LUSCHÜTZKY, Hans Christian. Variation and change in Morphology. Amsterdam/Philadelphia: John Benjamins, 2008, pp. 89-106.

GAFFIOT, F. Dictionnaire latin-français. Paris, Hachette, 1934.

GANZONI, Gian P. Grammatica ladina - grammatica sistematica dal rumantsch d' Engiadina Bassa per scolars e creschüts da lingua rumantscha e francesa. Samedan: Lia Rumantscha/ Ligia Romontscha, 1983.

GARCÍA, Erica C. Gender switch in Spanish derivation. RoPhil 1970(24):39-57.

GÉBELIN, Antoine Court de. Monde primitif analysé et comparé avec le monde moderne. Paris: Chez I'auteur/Valleyre/Sorin/Duran, 1773-1782.

. Histoire naturelle de la parole, ou précis de l'origine du langage \& de la grammaire universelle. Paris : Chez l'auteur/Boudet/Valleyre/Veuve Duchesne/Saugrain/Ruault, 1776.

GIANASTACIO, V. A presença do sufixo -ismo nas gramáticas da língua portuguesa e sua abrangência dos valores semânticos, a partir do Dicionário de Língua Portuguesa Antônio Houaiss. Dissertação de mestrado. São Paulo: FFLCH-USP, 2009.

GIVÓN, Talmy. Historical syntax and synchronic morphology: an archaeologist's field trip. Papers from the $7^{\text {th }}$ Regional Meeting. Chicago: Linguistic Society, 1971, pp. 394-415. . The time-axis phenomenon. Language. 1973 (49): 890-925.

GEERAERTS, Dirk. Prototype theory and diachronic semantics: a case study. Indogermanische Forschungen 1983a (88). . Reclassifying semantic change. Quaderni di Semantica. 1983b (4): 217-240. 
Cognitive restictions on the structure of semantic change. In: FISIAK, Jacek. Historical Semantics, Historical word-formation. Berlin/ New York/ Amsterdam: Mouton, 1985, pp. 127-153.

GLEASON, H. A. An introduction to descriptive linguistics. New York: Holt, Rinehart and Winston, 1961.

GONÇALVES, Anielle A. G. Diacronia e produtividade dos sufixos -agem, -igem, -ugem, -ádego, -ádigo e ádiga no português. 2009. Dissertação de Mestrado. São Paulo: FFLCH USP, 2009.

GÖTZ, Dieter. Studien zu den verdunkelten Komposita im Englischen. Nürnberg: Hans Carl, 1971.

GREENBERG, Joseph H. Some universals of grammar with particular references to the order of meaningful elements. In: GREENBERG, Joseph H. Universals of language. Cambridge, Mass. : MIT, 1963/6, pp. 5890.

Why does a language acquire gender markers? In: GREENBERG, Joseph H.; FERGUSON, Charles; MORAVCSIK, Edith A. Universals of human languages. v.3. Stanford : Stanford University Press, 1978, pp. 47-82.

; OSGOOD, C. E.; SAPORTA, S. Language change. In: OSGOOD, C.E. Psycholinguistics. Bloomington: Indiana University Press, 1965, pp. 146-163.

; FERGUSON, Charles; MORAVCSIK, Edith A. Universals of human languages. 4v. Stanford : Stanford University Press, 1978.

GRÉSILLON, Almuth. La règle et le monstre: le mot-valise. Interrogations sur la langue, à partir d'un corpus de Heinrich Heine. Tübingen : Niemeyer, 1984.

GRICE, H. Paul. Logic and conversation. In : COLE, P. ; MORGAN, J. L. Syntax and semantics, v.3: speechacts. New York: Seminar Press, 1975, pp. 41-58.

GRIMM, Jacob. Deutsche Grammatik. Göttingen: Dieterischsche Buchhandlung, v.1 $1819^{1}, 1822^{2}, 1840^{3}$, v.2 1826, v.3 1831, v.4 1837. [republ. por London: Routledge, 1999].

GRUAZ, Claude. La dérivation suffixale en français contemporain. Rouen : Université de Rouen, 1988.

GUERREIRO, Miguel do C. Tratado da versificaçaõ portugueza dividido em tres partes. Lisboa: Francisco Luiz Ameno, 1784.

GUILLAUME, Gustave. Langage et science du langage. Paris: Nizet \& Québec/ Presses de l'Université Laval, 1964.

GUIMIER, Claude. On the origin of the suffix -ly. In: FISIAK, Jacek. Historical Semantics, Historical wordformation. Berlin/ New York/ Amsterdam: Mouton, 1985, pp. 155-170.

GYARMATHI, Sámuel. Affinitas linguæ hungaricæ cum linguis fennicæ origines grammatice demonstrata. Göttingen: Typ. Joann. Christian. Dieterich, 1799.

HAIMAN, John. Iconic and economic motivation. Language. 1983(59): 781-819.

HALLE, M. Prolegomena to a theory of word formation. Linguistic inquiry. 1973 (4):3-16.

HARRIS, Alice C. \& FAARLUND, Jan Terje. Trapped Morphology. Journal of Linguistic, 2006(42): 289-315.

HARRIS, Zellig S. Morpheme alternants in linguistic analysis. Language, 1942 (18, 1): 169-180. . Structural linguistics. Chicago/London: The University of Chicago Press, 1947.

HASPELMATH, Martin. The diachronic externalization of inflexion. Linguistics, 1993 (31):279-309. . Understanding Morphology. London: Arnold, 2002.

; DRYER, Matthew S.; GIL, David; COMRIE, Bernard. The world atlas of language structures. Cambridge: CUP, 2005.

HECKLER, Evaldo; BACK, Sebald; MASSING, Egon A. Estrutura das palavras: famílias, morfologia, análise, origem. São Leopoldo: Unisinos, 1994.

HEGENBERG, Leônidas. Explicações científicas: introdução à filosofia da ciência. São Paulo: Herder, 1969. . Definições: termos teóricos e significado. São Paulo:Cultrix/Edusp, 1974.

HEINE, Bernd. Cognitive foundation of grammar. New York / Oxford: Oxford University Press, 1997. ; KUTEVA, Tania. World lexicon of grammaticalization. Cambridge: Cambridge University Press, 2002.

HELBERT, Robert K. Gender system and semanticity: two case histories from Bantu. In: FISIAK, Jacek. Historical Semantics, Historical word-formation. Berlin/ New York/ Amsterdam: Mouton, 1985, pp. 171-197.

HESSEN, Johannes. Erkenntnistheorie. Bonn: Ferdinand Dümmler, 1926 [Trad. Antônio Correia. Coimbra: Arménio Amado, 1980].

HEWSON, John. Derivation and inflection in English. In: JOLY, André; FRASER, Thomas. Studies in English grammar. Lille: Éditions Universitaires, 1975, pp. 77-104. 
HICKEY, Raymond. Segmental phonology and word-formation: agency and abstraction in the history of Irish. In: FISIAK, Jacek. Historical Semantics, Historical word-formation. Berlin/ New York/ Amsterdam: Mouton, 1985, pp. 199-219.

HIPPISLEY, Andrew. Paradigmatic reaignment and morphological change: diachronic deponency in Network Morphology. In: RAINER, Franz; DRESSLER, Wolfgang; KASTOVSKY, Dieter \& LUSCHÜTZKY, Hans Christian. Variation and change in Morphology. Amsterdam/Philadelphia: John Benjamins, 2008, pp. 107-128.

HJELMSLEV, Louis. Sproget: en introduktion. København: Berlingske Forlag, 1963.

HOCK, Hans Heinrich. Principles of Historical Linguistics. The Hague: Mouton, 1986.

HOCKETT, C. F. Problems of morphemic analysis. Language, 1947(23): 321-343. . Two models of grammatical description. Word, 1954 (10): 210-231. . A course of modern linguistics. New York: Harcourt \& Brace, 1958. . The origin of speech. Scientific American, 1960 (203): 89-96.

HOOPER, Joan Bybee. Child Morphology and morphophonemic change. In: FISIAK, Jacek. Historical Morphology. The Hague/ Paris/ New York: Mouton, 1980, pp. 157-187.

HOPPER, Paul J. \& TRAUGOTT, Elizabeth C. Grammaticalization. Cambridge: CUP, [1993 $\left.{ }^{1}\right] 2003$.

HOUAISS, Antônio; VILLAR, Mauro de S. (org.) Dicionário Houaiss da língua portuguesa. Rio de Janeiro: Objetiva, 2001.

HÜBNER, Ernst W. E. Inscriptiones Hispaniæ Christianæ. Berolini apud Georgium Reimerum, 1871 [reimpresso em Hildesheim/New York: Georg Olms, 1975].

HURCH, Bernard. On adjacency and related concepts. In: BERTINETTO, Pier Marco; KENSTOWICZ, Michael \& LOPORCARO, Michele (ed). Certamen phonologicum II. Torino: Rosenberg \& Sellier, 1991.

JACKENDOFF, R. J. Morphological and semantic regularities in the lexicon. Language 1975 (51): 639-671.

JAKOBSON, Roman. Signe zéro. In: Mélanges de linguistique, offerts à Charles Bailly. Geneva: Georg, 1939, pp. 143-152.

Linguistics and poetics. In: SEBEOK, Thomas. Style in language. Cambridge, Mass.: MIT, 1964, pp. 350-377.

. Quest for the essence of language. Diogenes, 1965 (51): 21-37.

. Two aspects of language and two types of aphasic disturbances. Selected writings, v.2: word and language. The Hague: Mouton, 1971, pp. 239-259.

JANSKY, Herbert. Lehrbuch der türkischen Sprache. Wiesbaden: Otto Harrassowitz, 1982.

JESPERSEN, Otto. A modern English grammar on historical principles. 6v. København: Ejnar Muksgaard, 1901-1942.

.Language: its nature, development and origin. London Allen \& Unwin, 1954 [1922 $\left.{ }^{1}\right]$. The philosophy of grammar. New York: W.W. Norton, 1924.

JONES, Charles. The functional motivation of linguistic change. English studies. 1967(48): 97-111.

JOOS, Martin (ed). Readings in Linguistics. New York: American Council of Learned Societies, 1958.

KAGER, René. Optimality theory. Cambridge: CUP, 1999.

KASTOVSKY, Dieter. The old English suffix -er(e). Anglia. 1971 (89): 285-325.

Wortbildung und Semantik. Düsseldorf/Bern: Schwan/Francke, 1982a.

Word-formation: a functional view. Folia linguistica 1982b (16): 181-198.

Deverbal nouns in Old and Modern Eglish: from stem-formation to word-formation. In: FISIAK, Jacek. Historical Semantics, Historical word-formation. Berlin/ New York/ Amsterdam: Mouton, 1985, pp. 221-261.

KATAMBA, Francis (ed). Morphology: critical concepts in Linguistics. London/ New York: Routledge, 2004.

KATZ, Jerrold J. Semantic theory. New York: Harper \& Row, 1972. ; POSTAL, Paul M. An integrated theory of linguistic descriptions. Cambridge, Mass.: MIT, 1964.

KEENAN, Edward L. Logical semantics and Universal Grammar. Theoretical Linguistics, 1978 (5): 83-107.

KERNAN, Elinor Ochs. Making it last: repetition in children's discourse. In: ERVIN-TRIPP, Susan; MITCHELLKERNAN, Claudia. Child discourse. New York: Academic Press, 1977, pp. 125-138.

KEMMER, Suzanne. Schemas and lexical blends: studies in honor of Günter Radden. In: CUYCKENS, Hubert et alii Motivation in language. Amsterdam: Benjamins, 2003, pp. 69-97. 
KIEFER, Ferenc. Areal-typological aspects of word-formation: the case of aktionsart-formation in German, Hungarian, Slavic, Baltic, Romani and Yiddish. In: RAINER, Franz; DRESSLER, Wolfgang; KASTOVSKY, Dieter \& LUSCHÜTZKY, Hans Christian. Variation and change in Morphology. Amsterdam/Philadelphia: John Benjamins, 2008, pp. 129-148.

KILANI-SCHOCH, Marianne \& DRESSLER, Wolfgang U. Morphologie naturelle et flexion du verbe français. Tübingen : Narr, 2005.

KING, R. D. Historical linguistics and generative grammar. Englewood Cliffs, N.J.: Prentice-Hall, 1969.

KIPARSKY, Paul. Linguistic universals and linguistic change. In: BACH, E.: HARMS, R. (ed) Universals in linguistic theory. New York: Holt, Rinehart \& Winston, 1968, pp. 171-202.

. Historical linguistics. In: DINGWALL, W. O. (ed) A survey of linguistic science. College Park: University of Maryland, 1971.

.'Elsewhere' in Phonology, em: ANDERSON, S.; KIPARSKY, Paul (eds.): Festschrift for Morris Halle. New York: Holt, Rinehart and Winston, 1973.

. Lexical Morphology and Phonology. Linguistics in the Morning Calm. Seoul:Hanskin, 1982:3-91.

KITTAY, Eva; LEHRER, Adrienne. Semantic fields and the structure of metaphor. Studies in Language, 1981(12): 35-46.

KJELLMAN, Hilding. Mots abrégés et tendances d'abbréviation en français. Uppsala: Akademiska Bokhandeln, 1920.

KJELLMER, Göran. Why weaken but not *strongen? On deadjectival verbs. English studies. 2:154-171, 2001.

KLAUSENBURGER, J. (De)morphologization in Latin. Lingua, 1976 (40): 305-320.

KLUGE, Friedrich. Etymologisches Wörterbuch der deutschen Sprache. Berlin: Walter de Gruyter, $1957^{17}$.

KOBLER-TRILL, Dorothea. Das Kurzwort im Deutschen: eine Untersuchung zu Definition, Typologie und Entwicklung. Tübingen: Niemeyer, 1994.

$\mathrm{KROCH}$, Anthony S. Syntactic change. In: MARTIN, Baltin; COLLINS, Chris. The handbook of contemporary syntactic theory. Malden: Blackwell, 2001.

KROTT, Andrea; BAAYEN, Harald; SCHREUDER, Rob. Analogy in Morphology: modeling the choice of linking morphemes in Dutch. Language and speech. 2007 (50): 533-566.

KRUSZEWSKI, Mikołaj Habdank. Über die Lautabwechslung. Kasan: Universitätsbuchdruckerei, 1881.

KUIPER, F. B. J. Die indogermanische Nasalpräsentia. Amsterdam: North Holland, 1937.

KURYŁOWICZ, Jerzy. La nature des procès dits 'analogiques'. Acta linguistica Hafniensia. 1949(5) : 15-37. . L'apophonie en indo-européen. Wrocław: Ossolineum, 1956.

The inflectional categories of Indoeuropean. Heidelberg: Carl Winter, 1964.

LABOV, W. The study of non-standard English. Urbana: National Council of Teachers of English, 1970. Sociolinguistic patterns. Oxford:??, 1978.

The boundaries of words and their meanings. In: BAILLEY, Ch.-J.; SHUY, R. New ways of analyzing variation in English. Washington D.C.: Georgetown University Press, 1973, pp. 370-373. "Building on empirical foundations". In: LEHMANN, W.P. \& MALKIEL, Y. (ed). Perspectives on historical linguistics. Amsterdam/ Philadelphia, John Benjamins Co., 1982.

LACOTIZ, Andréa. Estudo diacrônico da função e dos valores semânticos dos sufixos -ança/-ença/-ância/ência no português. Dissertação de mestrado. São Paulo: FFLCH-USP, 2007.

LAKOFF, George. Linguistic gestalts. In: BEACH, W. A.; FOX, S.E.; PHILOSOPH, S. Papers from the 13th Regional Meeting Chicago Society. Chicago: University Press, 1977, pp. 236-287.

. Categories and cognitive models. Trier, LAUT, series A 96, 1982.

. Classifiers as a reflection of mind. In: CRAIG, Colette (ed) Noun classes and categorization. Amsterdam/Philadelphia: Benjamins, 1986, pp. 13-51.

; JOHNSON, Mark. Metaphors we live by. Chicago: University Press, 1980.

LANGACKER, Ronald W. Semantic representations and the linguistic relativity hypothesis. Foundations of language. 1976 (14): 307-357.

. Syntactic reanalysis. In: Li, C. N. Mechanisms of syntactic change. Austin: University of Texas, 1977, pp. 57-140.

. Foundations of cognitive grammar I, II . Trier, LAUT, series A 99/100, 1983.

LAPPE, Sabine. English prosodic Morphology. Berlin : Springer, 2007.

LASS, R. On explaining language change. Cambridge: CUP, 1980. 
LASZLO, E. System, structure and experience. New York: Gordon \& Brea, 1969.

LEÃO, Duartes Nunes de. Ortografia e origem da língua portuguesa. Intr., notas e leit. d Maria L. Carvalhão Buescu. Lisboa, Casa da Moeda, 1983.

LECARME, Jacueline. Gender 'polarity': theoretical aspects of Somali nominal Morphology. In: BOUCHER, Paul \& PLENAT, Marc. Many Morphologies. Sommerville, Mass.: Cascadilla, 2002.

LEECH, Geofrey. Semantics: the study of meaning. Harmondsworth: Penguin, $1981^{2}$. ; COATES, Jennifer. Semantic indeterminacy and the modals. In: GREENBAUM, Sidney et alii. Studies in English linguistics for Randolph Quirk. London: Longman, 1980, pp. 79-90.

LEED, Richard L. Distinctive features and analogy. Lingua, 1970 (26): 1-24.

LEES, Robert B. The grammar of English nominalizations. Bloomington: Indiana University, 1960; The Hague: Mouton, $1962^{2}$.

LEHMANN, Christian. Thoughts on Grammaticalization. München: Lincom Europa, 1995.

LEHMANN, Winfred P.; MALKIEL, Yakov (ed). Directions for historical linguistics. Austin: University of Texas, 1968.

LEHRER, Adrienne. Semantic fields and lexical structure. Amsterdam: North Holland, 1974. Structure of the lexicon and transfer of meaning. Lingua. 1978 (45): 95-123.

. The influence of semantic fields on semantic change. In: FISIAK, Jacek. Historical Semantics, Historical word-formation. Berlin/ New York/ Amsterdam: Mouton, 1985, pp.283-296.

; BATTAN, P. L.. Semantic fields and semantic change. Coyote Papers, 1983(4).

LEIBNIZ, Gottfried W. von. Nouveaux essais sur l'entendement humain. Amsterdam/Leipzig: Jean Schreuder, 1765 (escrito entre 1701-1704).

LENNEBERG, Eric. Biological foundations on language. New York: John Wiley \& Sons, 1967.

LEPSIUS, C. Richard. Standard alphabet for reducing unwritten languages and foreign graphic systems to a uniform orthography in European letters. London / Berlin: Williams \& Norgate / W. Hertz, $1863^{2}$.

LEROY, Maurice. Les grands courants de la linguistique moderne. Bruxelles / Paris: Presses Universitaires de Bruxelles / Presses Universitaires de France, 1964.

LEWANDOWSKA-TOMASZCZYK, Barbara. On semantic change in a dynamic model of language. In: FISIAK, Jacek. Historical Semantics, Historical word-formation. Berlin/ New York/ Amsterdam: Mouton, 1985, pp. 297-323.

LI, Charles N. Contact-induced semantic change and innovation. In: FISIAK, Jacek. Historical Semantics, Historical word-formation. Berlin/ New York/ Amsterdam: Mouton, 1985, pp. 325-337.

LIEBER, Rochelle. On the organization of lexicon. Bloomington, IN:IULC, 1981. . Deconstructing Morphology: word formation in syntactic theory. Chicago/ London: The University of Chicago Press, 1992.

LIGHTFOOD, David. Principles of diachronic syntax. Cambridge: CUP, 1979. The language lottery: toward a biology of grammars. Cambridge, Mass.: MIT, 1982.

LIPKA, Leonhard. Semantic structure and word-formation: verb-particle constructions in contemporary English. München: Fink, 1972.

. Inferentail features in historical semantics. In: FISIAK, Jacek. Historical Semantics, Historical wordformation. Berlin/ New York/ Amsterdam: Mouton, 1985, pp. 339-354.

LONGOBARDI, Giuseppe. Formal Syntax, Diachronic Minimalism, and Etymology: the history of French chez. Linguistic Inquiry. 2001 (32):275-302.

LOPES, Nei. Novo dicionário banto do Brasil. Rio de Janeiro: Pallas, 2003.

LOPORCARO, Michele. Variation and change in Morphology and Syntax. In: RAINER, Franz; DRESSLER, Wolfgang; KASTOVSKY, Dieter \& LUSCHÜTZKY, Hans Christian. Variation and change in Morphology. Amsterdam/Philadelphia: John Benjamins, 2008, pp. 149-176.

LÖTSCHER, Andreas. Von Ajax bis Xerox: ein Lexikon der Produktennamen. Zürich: Artemis und Winkler, $1992^{2}$.

LÜDTKE, Helmut. Kommunikationstheoretische Grundlagen des Sprachwandels. Berlin: De Gruyter, 1980a. . The place of morphology in a universal cybernetic theory of language change. In: FISIAK, Jacek. Historical Morphology. The Hague: Mouton, 1980b, pp. 273-281.

. Diachronic irreversibility in word-formation and semantics. In: FISIAK, Jacek. Historical Semantics, Historical word-formation. Berlin/ New York/ Amsterdam: Mouton, 1985a, pp. 355-366. 
LYONS, John. Introduction to theoretical linguistics. Cambridge: CUP, 1971. Semantics. 2v. Cambridge: CUP, 1977.

MACHADO, José P. Dicionário etimológico da língua portuguesa. Rio de Janeiro, Presença, 1976.

MACWHINNEY, B. Rules, rote and analogy in morphological formations of Hungarian children. Journal of child language. 1975(2):65-77.

MAIDEN, Martin. Interactive Morphonology: metaphony in Italy. London/New York: Routledge, 1991.

MALKIEL, Yakov. Studies in irreversible binomias. In: MALKIEL, Yakov. Essay on linguistic themes. Berkeley: University of California, 1968.

. "Generic analyses of word formation". In: SEBEOK, Thomas A. (ed.) Current trends in linguistics. Paris, Moutom, 1970.

. Diachronic hypercharacterization in Romance. Archivium linguisticum. 1957 (9): 79-113; 1958 (10): 1-36.

MAŃCZAK, Witold. Tendances générales des changements analogiques. Lingua, 1957-1958 (7) : 298-325, 387-420.

. Origine de l'apophonie e/o en indo-européen. Lingua, 1960 (9) : 277-287.

. Tendances générales du développement morphologique. Lingua 1963 (12) : 19-38.

. La nature du supplétivisme. Linguistics. 1966 (28): 82-89.

. Fonetica e morfologia storica dell'italiano. Kraków : Universytet Jagielloński, 1976.

. Les lois du développement analogique. Linguistics 1978(205):53-60.

. Laws of analogy. In: FISIAK, Jacek. Historical Morphology. The Hague/ Paris/ New York: Mouton, 1980, pp. 283-288.

Semantic development of borrowings. In: FISIAK, Jacek. Historical Semantics, Historical wordformation. Berlin/ New York/ Amsterdam: Mouton, 1985, pp. 367-375.

MARCHAND, Hans. The types and categories of present-day English word formation. München: Beck, 1969.

MARCOS-MARIN, Francisco. Etymology and semantics: theoretcal considerations apropos of an analysis of the etymological problem of spanish mañero, mañería. In: FISIAK, Jacek. Historical Semantics, Historical word-formation. Berlin/ New York/ Amsterdam: Mouton, 1985, pp.377-395.

MARTINET, André. Économie des changements phonétiques. Berne: Francke, 1955. . La linguistique synchronique. Paris : PUF, 1965. . Grammaire fonctionelle du français. Paris: PUF, 1979.

MARTINS, Nilce S. O léxico de Guimarães Rosa. São Paulo: Edusp, $2001^{2}$.

MATTHEWS, Peter H. Morphology. Cambridge: CUP, 1974.

MATTOS E SILVA, Rosa V. "A sócio-história do Brasil e a heterogeneidade do português brasileiro: algumas reflexões". Boletim da Abralin 17 (1995): 73-85.

. Estruturas trecentistas: elementos para uma gramática do português arcaico. Lisboa, Imprensa Nacional Casa da Moeda, 1999. . Caminhos da linguística histórica: ouvir o inaudível. São Paulo: Parábola, 2008.

MAURER Jr. Theodoro H. A unidade da România ocidental. São Paulo, FFLCH, 1951.

MAYERTHALER, Willi. Morphologischer Ikonismus. Zeitschrift für Semiotik. 1980(2): 19-37. . Morphologische Natürlichkeit. Wiesbaden: Athenaion, 1981.

McMAHON, April. Understanding language change. Cambridge: CUP, 1994.

MEID, Wolfgang. Beziehungen zwischen äußerer und innerer Sprachform: verschränkte Zeichen und fusionierte Inhalte. Veröffentlichungen der Kommission für Linguistik und Kommunikationsforschung . Anzeiger der phil.-hist. Klasse. Wien: Verlag der Österreichischen Akademie der Wissenschaften, 1977 (114): 6, 294-304.

MEIER, G. F. Das Zero-problem in der Linguistik. Berlin: Akademie, 1961.

MEILLET, Antoine. Linguistique historique et linguistique générale. Paris : Champion, 1921.

MEL'ČUK, Igor. On suppletion. Linguistics. 1976a(170): 45-90. . Suppletiologie Etüden. Wiener Linguistische Gazette. 1976b(12):57-65.

. Towards a language of linguistics. München: Fink, 1982.

. Cours de morphologie génerale. 5v. Montréal/Paris: Presses de l'Université de Montréal/CNRS, 1993-2000.

. Aspects of the theory of Morphology. Berlin/New York: Mouton de Gruyter, 2006. 
MENÉNDEZ-PIDAL, Ramón. Orígenes del español. Madrid: Espasa Calpe, $1956^{4}$.

METTMANN, Walter. (ed.) Cantigas de Santa María. Madrid: Castalia, 1988. 3v. . Cantigas de Santa Maria. Coimbra: Universidade de Coimbra, 1959-1972. 4v.

MEYER-LÜBKE, Wilhelm. Romanisches etymologisches Wörterbuch. Heidelberg, Carl Winters, $1972^{5}$.

MIESTAMO, Matti; SINNENMÄLI, Kaius; KARLSSON, Fred. Language complexity: typology, contact, change. Amsterdam/ Philadelphia: Benjamins, 2008.

MORAVCSIK, Edith A. Redulicative constructions. In: FERGUSON, Charles A.; MORAVCSIK, Edith A. Universals of human language, v.3. Stanford: Stanford University Press, 1978, pp. 297-334.

MUGDAN, Joachim. Flexionsmorphologie und Psycholinguistik. Tübingen : Günter Narr, 1977. . Was ist eigentlich ein Morphem? Zeitschrift für Phonetik, Sprachwissenschaft und Kommunikationsforschung. 1986 (39,1): 29-43.

. On the history of linguistic terminology. In: NIEDEREHE, Hans-Joseph; KOERNER, Konrad (ed). History and Historiography of Linguistics. Amsterdam/Philadelphia: Benjamins, 1990, pp. 49-61.

NAU, Nicole. Introduction. Sprachtypologie und Universalienforschung. 54(3):185-196.

NEBRIJA, Elio A. de. Gramática castellana. Intr. y notas Miguel Ángel Esparza y Ramón Sarmiento. Madrid, Fundación Antonio de Nebrija, 1992.

. Gramática castellana. Texto estab. sobre la ed. princ. 1492 por Pascual Galindo Romeo e Luiz Ortiz Muñoz. Madrid, Junta del Centenario, 1946.

NEEF, Martin. Wortdesign: eine deklatarive Analyse der deutschen Verbflexion. Tübingen: Stauffenburg, 1996.

NIDA, E. The identification of morphemes. Language. 1948 (24): 414-441. . Morphology: the descriptive analysis of words. Ann Arbor, MI: The University of Michigan Press, $1961\left[1946^{1}\right]$

NÖTH, Winfried. Contrastive semantics in the light of the theory of semantic change. Anglistik \& Englischunterricht. 1979 (8):25-39.

NÜBLING, Damaris. Auf der Suche nach dem idealen Eigennamen. Beiträge zur Namenforschung. 2000 (35): 275-302.

NUNES, José Joaquim. Compêndio de gramática histórica portuguesa. História e Morfologia. Lisboa, Clássica, 1945.

NYROP, Kristoffer. Grammaire historique de la langue française. v.3. København : Gyndendalske Boghandel Nordisk Forlag, 1936.

OCHS, Elinor. Planned and unplanned discurs. In: GIVÓN, Talmy. Syntax and Semantics, v. 12: discourse and semantics. New York, Academic Press, 1979, pp. 51-80.

OGDEN, C. K.; RICHARDS, I. A. O significado de significado. Rio de Janeiro: Zahar, 1976.

OLIVEIRA, Alberto J. de Dicionário gaúcho: termos, expressões, adágios, ditados e outras barbaridades. Porto Alegre: AGE, 2002.

OLIVEIRA, Fernão de. Gramática da linguagem portuguesa. Repr. facsim. Lisboa, Biblioteca Nacional, 1988. Grammatica da linguagem portuguesa. Dir. Rodrigo de Sá Nogueira. Lisboa, Tip. Beleza, 1933. . A Gramática da linguagem portuguesa. Intr., leit. act. e notas por Maria L. C. Buescu. Lisboa, Casa da Moeda, 1975.

. Gramática da linguagem portuguesa. Edição crítica, semidiplomática e anastática por Amadeu Torres e Carlos Assunção com um estudo introdutório de Eugenio Coseriu. Lisboa: Academia de Ciências de Lisboa, $\left[1536^{1}\right] 2001$.

ORTMANN, Albert. Affix repetition and non-redundancy in inflexional Morfology. Zeitschrift für Sprachwissenschaft. 1999(18):1.76-120.

OSTHOFF, Hermann. Das physiologische und psychologische Moment in der sprachlichen Formenbildung. Berlin: Habel, 1879.

PANAGL, Oswald. Morphologische hypercharakterisierung im Vulgärlatein. In: PETERSMANN, Hubert \& KETTEMAN, Rudolf. Latin vulgaire - latin tardif $V$; actes du Ve Colloque international sur le latin vulgaire et tardif. Heidelberg: Winter, 1999, pp. 49-57.

PAPAVERO, Nelson; TEIXEIRA, Dante M.; LLORENTE-BOUSQUETS, Jorge. História da biogeografia no período pré-evolutivo. São Paulo: Plêiade/FAPESP, 1997.

PAUL, Hermann. Prinzipien der Sprachgeschichte. Tübingen: Niemeyer, $1920^{5}$. 
PASTER, Mary. Optional multiple plural marking in Maay. In: RAINER, Franz; DRESSLER, Wolfgang; KASTOVSKY, Dieter \& LUSCHÜTZKY, Hans Christian. Variation and change in Morphology. Amsterdam/Philadelphia: John Benjamins, 2008, pp. 177-192.

PEREIRA, Bento. Regras gerays breves e comprehensivas da melhor ortografia. Lisboa, Domingos Carneiro, 1666.

PETERS, Stanley (ed). Goals of linguistic theory. Englewood Cliffs, N.J.: Prentice-Hall, 1972.

PHARIES, David. The origin and development of the Ibero-Romance -nc-/-ng- suffixes. Zeitschrift für romanische Philologie. Beiheft 228. Tübingen: Niemeyer, 1990.

PIKE, Kenneth. Language in relation to a unified theory of the structure of human behavior. The Hague: Mouton, 1967.

PILCH, Herbert. The synchrony-diachrony division in word-formation. In: FISIAK, Jacek. Historical Semantics, Historical word-formation. Berlin/ New York/ Amsterdam: Mouton, 1985, pp. 407-433.

PLAG, Ingo. Morphological productivity: structural constraints in English derivation. Berlin / New York: Mouton de Gruyter, 1999. Word formation in English. Cambridge: CUP, 2003.

. The variability of compound stress in English: structural, semantic, and analogical factors. English language and linguistics. 2006(10): 143-172.

PLANK, Frans. Inflection and derivation. In : ASHER, Robert A. The encyclopedia of language and linguistics. Oxford: Pergamon, 1994, pp. 1671-1678.

Morphologische (Ir-)Regularitäten. Tübingen : Narr, 1981.

PLÉNAT, Marc. Les constraintes de taille. In : FRADIN, Bernard; KERLEROUX, Françoise; PLÉNAT, Marc. Aperçus de morphologie du français. Saint-Denis : Presses Universitaires de Vincennes, 2009, pp. 4763.

- Quelques considérations sur la formation des gentilés. In: FRADIN, Bernard. La raison morphologique: hommage à la mémoire de Danielle Corbin. Amsterdam / Philadelphia: John Benjamins, 2008 : 155-174.

POKORNY, Julius. Indogermanisches etymologisches Wörterbuch. Bern: Francke, 1959.

POTTIER, Bernard. Lingüística moderna y filología hispánica. Madrid: Gredos, 1968.

POUND, Louise. Blends : their relation to English word formation. 1914 ${ }^{1}$. Amsterdam : Swets \& Zeitlinger, $1967^{2}$.

RAINER, Franz. Constraints in productivity. In: ŠTEKAUER, Pavol; LIEBER, Rochelle. Handbook of wordformation. Dordrecht: Springer, 2005:335-352.

RANDALL, Janet. -ity: a study in word formation restrictions. Journal of Psycholingustic research. 1980(9).6: 523-534.

REISCHER, Jürgen. Die Wortkreuzung und verwandte Verfahren der Wortbildung: eine korpusbasierte Analyse des Phänomens 'Blending' am Beispiel des Deutschen und Englischen. Hamburg: Kovač, 2008.

REY-DEBOVE, Josette \& REY, Alain (ed.) Le nouveau petit Robert. Paris: Le Robert, 1993.

RHODES, Richard. What is a morpheme? A view from Construction Grammar. Berkeley Linguistics Society. 1992 (18): 409-423.

RIDDLE, Elizabeth M. A historical perspective on the productiviy of the sufixes -ness and -ity. In: FISIAK, Jacek. Historical Semantics, Historical word-formation. Berlin/ New York/ Amsterdam: Mouton, 1985, pp. 435-461.

RIHA, Helena \& BAKER, Kirk. Lettered words: using Roman letters to create words in Chinese. In: RAINER, Franz; DRESSLER, Wolfgang; KASTOVSKY, Dieter \& LUSCHÜTZKY, Hans Christian. Variation and change in Morphology. Amsterdam/Philadelphia: John Benjamins, 2008, pp. 193-200.

RIO-TORTO, G. M. O. S. Formação de palavras em português: aspectos da construção de avaliativos. Diss. doutoramento. Coimbra: Universidade de Coimbra, 1993.

. Morfologia derivacional: teoria e aplicação ao português. Porto: Porto Ed., 1998. et al. (org). Verbos e nomes em português. Coimbra: Almedina, 2004.

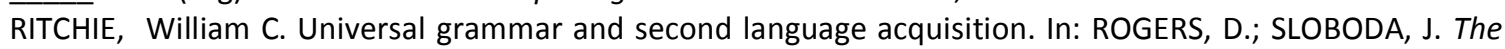
acquisition of symbolic skills. New York: Plenum, 1983, pp. 471-483.

. Word-formation, learned vocabulary and linguistic maturation. In: FISIAK, Jacek. Historical Semantics, Historical word-formation. Berlin/ New York/ Amsterdam: Mouton, 1985, pp. 463-482. 
ROCHA, Luiz C. de A. Estruturas morfológicas do português. Belo Horizonte: UFMG, 1998.

ROHLFS, G. Grammatica storica della lingua italiana e dei suoi dialetti. 2: Morfologia. Torino: Einaudi, 1968.

RONNEBERGER-SIBOLD, Elke. Sprachverwendung, Sprachsystem, Ökonomie und Wandel. Tübingen: Niemeyer, 1980.

. Preferred sound shapes o new roots: on some phonotactic and prosodic properties of shortenings in German and French. In: HURCH, Bernhard; RHODES, Richard. Natural Phonology, the state of art. Berlin/New York: Mouton de Gruyter, 1996, pp. 261-292.

. On useful darkness: loss and destruction of transparency by linguistic change, borrowing and word creation. Yearbook of Morphology 1999. 2001:97-120.

Volksetymologie und Paronomasie als lautnachahmende Wortschöpfung. In: HABERMANN, Mechthild; MÜLLER, Peter O.; MUNSKE, Horst Haider. Historische Wortbildung des Deutschen. Tübingen: Niemeyer, 2002, pp. 105-127.

. On the phonostylistic funciton of prototypical nonnative sound shapes in contemporary German: evidence from the history of brand names. In: DZIUBALSKA-KOŁACZYK, Katarzyna; WECKWERTH, Jarosław. Future challenges for natural Linguistics. München: Lincom Europa, 2002, pp. 211-231.

. Warennamen. In: BRENDLER, Andrea; BRENDLER, Silvio. Namenarten und ihre Erforschung: ein Lehrbuch für das Studium der Onomastik. Hamburg: Baar, 2004, pp. 557-603.

. Lexical blends: functionally tuning the transparency of words. Folia linguistica, 2006 (40): 155-181.

. Word creation: definition - function - typology. In: RAINER, Franz; DRESSLER, Wolfgang; KASTOVSKY, Dieter \& LUSCHÜTZKY, Hans Christian. Variation and change in Morphology. Amsterdam/Philadelphia: John Benjamins, 2008, pp. 201-216.

- Thermodur, Blend-a-med, Sivitrex: Konfixe in deutschen Markennamen: Typen - Geschichte Funktionen. Germanistische Linguistik. 2009 (197/198): 141-193.

ROSCH, Eleonor. Natural categories. Cognitive Psychology. 1973 (4):328-350.

. Cognitive representations of semantic categories. Journal of experimental Psychology. 1975 (104): 192-233.

. Human categorization. In: WARREN, N. Studies in cross-cultural psychology. New York: Academic Press, 1977, pp. 1-49.

. Principles of categorization. In: ROSCH, E.; LLOYD, B.B. Cognition and categorization. Hillsdale: Erlbaum, 1978, pp. 27-48.

; MERVIS, C.B. Family resemblances: study in the internal structure of categories. Cognitive Psychology. 1975(7):573-605.

; ___ Categorization of natural objects. Annual review of Psychology. 1981 (32): 89-115.

RUDES, Blain A. On the nature of verbal suppletion. Linguistics. 1980 (18):655-676.

SADLER, Louisa; SPENCER, Andrew. Syntax as an exponent of Morphological features. Yearbook of Morphology 2000. Dordrecht: Kluwer, 2001, pp. 71-96.

SAEED, John I. Somali reference grammar. Wheaton, Maryland: Dunwoody, 1987.

SAID ALI, Manoel. Lexeologia do portuguez historico. São Paulo: Melhoramentos, 1921. . Gramática histórica da língua portuguesa. 8. ed. São Paulo/ Brasília: Melhoramentos/ UnB, 2001.

SALMON, Paul. "The term 'Morphology'", em Booij, Geert / Christian Lehmann / Joachin Mugdan (eds.), Morphologie: ein internationales Handbuch zur Flexion und Wortbildung. Berlin / New York: Walter de Gruyter, 2000, p. 15-22.

SANDMANN, Antônio J. Formação de palavras no português brasileiro contemporâneo. Curitiba: Scientia et Labor/Ícone, 1989.

SANKOFF, Gillian. Linguistic outcomes of language contact. In: CHAMBERS, J. K.; TRUDGILL, Peter; SCHILINGESTES, Natalie. The handbook of language variation and change. Oxford: Blackwell, 2002, pp. 638-668.

SANTOS, Alice P. Polissemia dos sufixos aumentativos -ão, -arro, -orro, -aço e -uço e seus traços avaliativos sob a perspectiva diacrônica São Paulo: FFLCH-USP, 2010.

SAPIR, Edward. Language. New York: Harcourt, Brace \& World, 1921.

SAUSSURE, Ferdinand de. Cours de linguistique générale. Paris: Payot, 1916 [Ed. Tullio de Mauro Paris: Payot, 1973].

SAVICKIENĖ, Ineta. The acquisition of Lithuanian noun Morphology. Vienna: Österreichische Akademie der Wissenschaften, 2003. 
SCHLESINGER, I. M. The grammar of sign language and the problem of language universals. In: MORTON, J. (ed). Biological and social factors in psycholinguistics. London: Logos, 1971, pp. 98-121.

SCHUCHARDT, Hugo E. M. Der Vokalismus des Vulgärlateins. 3v. Leipzig: Teubner, 1866-1868. Über die Lautgesetze - Gegen die Junggramatiker. Berlin: R. Oppenheim, 1885

SEBEOK, Thomas et alii (ed) Current trends in linguistics. v.2. The Hague: Mouton, 1971.

SERRA E GURGEL, J. B. Dicionário de gíria: modismo lingüístico, o equipamento falado do brasileiro. Brasília: JB Serra e Gurgel, $1995^{3}$.

SIGURD, Bengt. Generative grammar and historical linguistics. Acta linguistica hafniensia. 1966 (10): 35-48.

SILVA, Augusto S. da; TORRES, Amadeu; GONÇALVES, M. Linguagem, cultura e cognição: emementos de linguística cognitiva. 2v. Coimbra: Almedina, 2004.

SIMÕES, Lisângela. Estudo semântico e diacrônico do sufixo -dade na língua portuguesa. Dissertação de mestrado. São Paulo: FFLCH-USP, 2009.

SIMÕES, Maria C. P.; STOEL-GAMMON, Carol. The acquisition of inflections in Portuguese: a study of the development of person markers on verbs. Journal of Child language. 1978 (6): 53-67.

SKOUSEN, Royal; LONSDALE, Deryle; PARKINSON, Dilworth B. Analogical modelin: an exemplar-based approach to language. Amsterdam/Philadelphia: Benjamins, 2002.

SLOBIN, D. I. Cognitive prerequisites for the development of grammar. In: FERGUSON, C. A.; SLOBIN, D. I. (ed) Studies in child language development. New York: Holt, Rinehart and Winston, 1973. . Language change in childhood and in history. In: MACNAMARA, John. Language learning and thought. New York: Academic, 1977, pp. 185-214.

SOUDEK, Lev I. The relation of blending to English word-formation: theory, structure and typological attempts. In: DRESSLER, Wolfgang; MEID, Wolfgang. Proceedings of the twelfth International Congress of Linguists. Innsbruck: Institut für Sprachwissenschaft, 1978, pp. 462-466.

SPENCE, Nicol C. W. Linguistic fields, conceptual systems and the Weltbild. Transactions of the Philological Society. 1961: 88-106.

SPENCER, Andrew. Morphological theory : an introduction to word structure in Generative Grammar. Oxford: Blackwell, 1991.

SPORE, Palle. Les suffixes -ais et -ois ajoutés à un nom de ville. In: Lorenzo, Ramón. Actas do XIX Congreso Internacional de Lingüística e Filoloxía Románicas- Santiago de Compostela 1989. v.4. A Coruña: Fundación “Pedro Barrié de la Maza, Conde de Fenosa”. 1993. pp. 453-468.

SPRENGEL, Konrad. Über semantische Merkmale. In: KASTOVSKY, Dieter. Perspektiven der lexikalischen Semantik. Bonn: Bouvier, 1980, pp. 145-177.

STEINHAUER, Anja. Sprachökonomie durch Kurzwörter: Bildung und Verwendung in der Fachkommunikation. Tübingen: Narr, 2000.

ŠTEKAUER, Pavol. English word formation: a history of research (1960-1995). Tübingen: Günter Narr, 2000.

STERN, G. Meaning and change of meaning, with special reference to the English language. Bloomington: University of Indiana Press, $1931 ; 1968^{2}$

STOCKWELL, Robert P.; MACAULAY, Ronald K. S. (ed) Linguistic change and generative theory. Bloomington: Indiana University Press, 1972.

STOLZ, Thomas. Pleonastic Morphology dies hard: change and variation of definiteness inflection in Lithuanian. In: RAINER, Franz; DRESSLER, Wolfgang; KASTOVSKY, Dieter \& LUSCHÜTZKY, Hans Christian. Variation and change in Morphology. Amsterdam/Philadelphia: John Benjamins, 2008, pp. 217-244.

STRAUSS, Jürgen. The lexicological analysis of older stages of languages. In: FISIAK, Jacek. Historical Semantics, Historical word-formation. Berlin/ New York/ Amsterdam: Mouton, 1985, pp. 573-582.

STUMP, Gregory. Inflectional Morphology: a theory of paradigm structure. Cambridge: CUP, 2001.

TALMY, Leonard. Yiddish verb prefixes between Germanic and Slavic. Proceedings of the eighth annual meeting of the Berkeley Linguistic Society. Berkeley: Berkeley Linguistic Society, 1982, pp. 231-250.

TALO, Ewa Söderpalm. Slips of the tongue in normal and pathological speech. In: FROMKIN, Victoria. Errors in linguistic performance. Slips of the tongue, ear, pen and hand. New York: Academic Press, 1980, pp. 81-86.

TARALLO, F. A pesquisa sociolingüística. São Paulo, Ática, 1994. . Tempos lingüisticos; itinerário histórico da pesquisa portuguesa. São Paulo, Ática, 1990. 
TEKAVČIĆ, Pavao. Grammatica storica dell'italiano. 3v. Bologna: Il Mulino, 1972.

TESNIÈRE, Lucien. Eléments de syntaxe structurale. Paris: Klincksieck, 1959.

TEYSSIER, Paul. História da língua portuguesa. Trad. Celso Cunha. Lisboa: Sá da Costa, 1990. [Paris:PUF, $\left.1980^{1}\right]$.

THOMASON, S. G. Analogical change as grammar complication. In: CHRISTIE, William (ed). Current progress in historical linguistics. Amsterdam: North-Holland, 1976, pp. 401-409.

TRIER, Jost. Der deutsche Wortschatz im Sinnbezirk des Verstandes. Heidelberg: Winter, 1931.

ULLMANN, Stephan. The principles of semantics. Glasgow: Jackson, Son \& Co, $1957^{2}$ . Semantics: an introduciton to the science of meaning. Oxford: Basil Blackwell, 1972. [ tradução portuguesa: Semântica: uma introdução à ciência do significado. Lisboa: Calouste Gulbenkian, 1973].

VÄÄNÄNEN, Veikko. La préposition latine de et le génitive : une mise au point. Revue de linguistique romane, 1956 (20): :1-20. . Introducción al latín vulgar. Trad. Manuel Carrión. Madrid: Gredos, 1985 [Paris:Klincksieck, $1967^{1}$ ].

VASCONCELOS, José Leite. Opusculos. Coimbra: Imprensa da Universidade, 1928, v.1.

VENNEMANN, Theo. Phonetic analogy and conceptual analogy. In: VENNEMAN, Theo; WILBUR, Terence H. (ed) Schuchardt, the Neogrammarians, and the transformational theory of phonological change. Frankfurt: M. Athenäum, 1972a, pp. 181-204. . Rule inversion. Lingua, 1972b (29): 209-242.

. An explanation of drift. In: LI, C. N. (ed). Word order and word order change. Austin: University of Texas, 1975, pp. 269-305.

VÉRA, Álvaro Ferreira. Orthographia ou modo para escrever certo na lingua portuguesa. Lisboa, Mathias Rodriguez, 1631.

VIARO, Mário E. Para um estudo de semântica sincrônica dos sufixos derivacionais em português do séc. XIII. Grupo de Estudos Lingüísticos do Estado de São Paulo. Taubaté: Unitau, 2003. CD-ROM (com. 95). . Sufixação nas Cantigas de Santa Maria . In: Congresso Brasileiro de Língua Portuguesa do IPPUC/SP, 2004, São Paulo. Anais do IX Congresso Brasileiro de Língua Portuguesa. CD-ROM,São Paulo : IP-PUC-SP, 2004.

Relação entre produtividade e freqüência na produção do significado. Estudos Lingüísticos, Campinas, 2005a, v. 34, p. 1230-1235.

Os sufixos portugueses numa visão diacrônica . In: XVI Seminário do Cellip (Centro de Estudos Lingüísticos e Literários do Paraná), 2005, Londrina. Anais do XVI Cellip. Londrina : Universidade Estadual de Londrina/Cellip/Fundação Araucária, 2005b.

.Problemas de morfologia e semântica histórica do sufixo -eiro. Estudos Lingüísticos 35, 2006, 1443 1452.

. Estudo diacrônico da formação e da mudança semântica dos sufixos -eiro/-eira na língua portuguesa. In: MASSINI-CAGLIARI, Gladis et alii (org) Trilhas de Mattoso Câmara e outras trilhas: fonologia, morfologia, sintaxe. São Paulo: Cultura Acadêmica, 12: 45-84, 2007a.

Reconstrução lexical do português paulista. Revista do Gel, Campinas, n. 4, p. 39-53, 2007b.

. Os sufixos -eiro e -ário: história de morfemas divergentes. In: LIMA-HERNANDES, M.C.; MARÇALO, M.J.; MICHELETTI, G.; ROSSI, V.L... (Org.). A Língua Portuguesa no Mundo - I Simpósio Mundial de Estudos de Língua Portuguesa (CD-ROM). São Paulo: FFLCH USP, v. 2, 2008.

. A especialização do sufixo latino -arium. In: MARÇALO, M.J. \& LIMA-HERNANDES, M. C. et alli. (Org.). Língua portuguesa: ultrapassar fronteiras, juntar culturas. Évora: Universidade de Évora, 2010a, p. 22-42.

Sobre a inclusão do elemento diacrônico na teoria morfológica: uma abordagem epistemológica. Estudos de Lingüística Galega. Santiago de Compostela, 2: 173-190, $2010 \mathrm{~b}$.

Etimologia. São Paulo: Contexto, 2011.

; GUIMARÃES FILHO, Zwinglio $O$. Análise quantitativa da freqüência dos fonemas e estruturas silábicas portuguesas. Estudos Lingüísticos. São Paulo, 36: 28-36, 2007.

; GUIMARÃES FILHO, Zwinglio 0 . Acerca dos diferentes graus de distinção em fonologia: o caso dos fonemas portugueses em dissílabos do tipo cvcv. Filologia e Linguística Portuguesa. São Paulo, 12(1): 125-148, 2010. 
VICENTE, Gil. Copilaçam de todalas obras de Gil Vicente. Organização por Maria Leonor Carvalhão Buescu, Lisboa: Imprensa Nacional/ Casa da Moeda, 1983. 2v.

VILLALBA, Alina. Estruturas morfológicas do português: unidades e hierarquias nas palavras do português. Lisboa: Calouste Gulbenkian/ Fundação para a Ciência e Tecnologia, 2000.

VINCENT, N. Is sound change teleological? In: In: FISIAK, Jacek. Recent developments in historical phonology. The Hague: Mouton, 1978, pp. 409-430.

VIP, Angelo; LIBI, Fred. Aurélia, a dicionária da língua afiada. São Paulo: Editora da Bispa, 2006.

VITERBO, Fr. Joaquim de Santa Rosa de. Elucidário das palavras, termos e frases que em Portugal antigamente se usavam e que hoje regularmente se ignoram... Ed. cr. por M. Fiúza. Porto Alegre, Civilização, 1962. 2v.

WALDE, A. Lateinisches etymologisches Wörterbuch. Heidelberg: Winter, $1910^{2}$ [reeditada por HOFMANN, J. B. $1930 \mathrm{ss}^{3}$ ].

WANG, W. Competing changes as a cause fo residue. Language, 1969 (45):9-25.

WARREN, Beatrice. The importance of combining forms. In: DRESSLER, Wolfgang et alii. Contemporary Morphology. Berlin: Mouton de Gruyter, 1990, pp. 111-132.

WARTBURG, Walther von. Französisches etymologisches Wörterbuch. Basel: R> G. Zbinden, 1928ss.

WEINREICH, Uriel. Languages in contact. The Hague: Mouton, 1953. ; LABOV, WIliam \& HERZOG, Marvin I. Empirical foundations for a Theory of Language Change. In: LEHMANN, Winfried P. \& MALKIEL, Yakov. Directions for Historical Linguistics: a symposium. Austin: University of Texas, 1968, pp. 95-188.

WEŁNA, Jerzy. On gender change in linguistic borrowing (Old English). In: FISIAK, Jacek. Historical Morphology. The Hague/ Paris/ New York: Mouton, 1980, pp. 399-420.

WERNER, Otmar. The aim of morphological change is a good mixture - not a uniform language type. In: RAMAT, Anna Giacalone; CARRUBA, Onofrio; BERNINI, Giuliano. Papers from the $7^{\text {th }}$ International Conference on Historical Linguistics. Amsterdam: Benjamins, 1987, pp. 591-606.

WHEELER, Benjamin Ide. Analogy and the scope of its application in language. New York: Johnson, 1887, $1965^{2}$.

WIERZBICKA, Anna. Semantic primitives. Frankfurt a.M.: Athenäum, 1972. . The semantics of grammar. Amsterdam/ Philadelphia: Benjamins, 1988. Semantics: primes and universals. Oxford/ New York: OUP, 1996.

WINTER, Werner. Analogischer Sprachwandel und semantische Struktur. Folia linguistica. 1969 (3): 29-45. . Formal frequency ad linguistic change: some preliminary comments. Folia linguistica 1970(5): 55-61.

WOLF, Heinz Jürgen. Anmerkungen zu den französischen Bewohnernamen. Beiträge zur romanischen Philologie. 1982 (21): 153-167.

WIERZBICKA, Anna. Semantics: primes and universals. Oxford/New York: Oxford University Press, 1996.

WILLIAMS, Joseph M. Synaesthesic adjectives: a possible law of semantic change. Language 1976 (52): 461 478.

WUNDERLICH, Dieter; FABRI, Ray. Minimalist Morphology: an approach to inflection. Zeitschrift für Sprachwissenschaft. 1996(14):2.236-294.

WURZEL, Wolfgang U. Zur Stellung der Morphologie im Sprachsystem. Linguistische Studien, Reihe A, 1977 (35): 130-165.

. Ways of morphologizing phonological rules. In: FISIAK, Jacek. Historical Morphology. The Hague/ Paris/ New York: Mouton, 1980, pp. 443-462.

. Faktoren des Sprachwandels. Papiere zur Linguistik. 1991 (44/45):1/2.159-174.

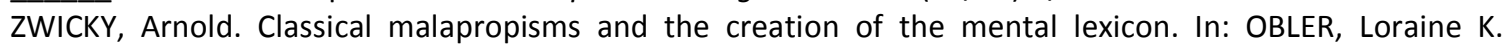
Exceptional language and Linguistics. New York: Academic Press, 1982, pp. 115-132.

Clitics and particles. Langugage. 1985(61):2.283-305.

; PULLUM, Geoffrey. Plain Morphology and expressive Morphology. In: ASKE, Jon et alii. Proceedings of the thirteenth annual meeting, February 14-16, 1987: General session and Parasession on Grammar and Cognition. Berkeley: Berkeley Linguistics Society, 1987, pp. 330-340. 